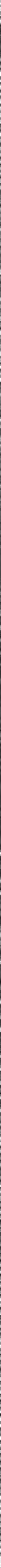




\section{GEO. H. DIXON}

LAW BOOKSELLER AND PUBLISHER

522 Walnut St. Philadelphía

\section{UNIVERSITY OF CALIFORNIA LOS ANGELES}

SCHOOL OF LAW LIBRARY 




\title{
THE LAW OF
}

\section{LANDLORD AND TENANT}

IN

\section{Pennsylvania}

\author{
BY \\ RICHARD J. WILLIAMS \\ Of the Philadelphia Bar
}

SECOND EDITION

PHILADELPHIA

T. \& J. W. JOHNSON \& CO. 


$$
\begin{gathered}
T \\
W 6753 \mathrm{~L} \\
1901
\end{gathered}
$$

\section{COPYRIGHT, rgor,}

BY

T. \& J. W. Johnson \& Co.

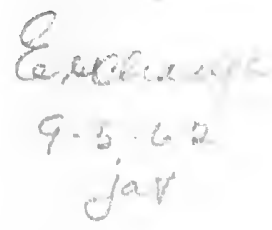




\section{TABLE OF CONTENTS.}

\section{CHAPTER I.}

\section{LEASES.}

PAGE 5.

Agreements for a Lease. SECTION

I. Directions for preparing.

2. A specific performance will be decreed.

3. Damages for a breach of an agreement for a lease.

4. Where a tenant under a parol agreement for a lease is let into possession and makes improvements.

5. A lease completed by an actual entry of the tenant.

Parol Evidence as applied to WRITTEN AGREEMENTS.

6. Admissible in case of fraud, accident or mistake.

7. Admissible in some other cases.

8. Agreement in writing to exclude verbal understandings, etc.

\section{Construction of Leases.}

9. Rules for construction.

The Nature of a Lease.

10. Definition of a lease.
SECTION

II. Distinction between a lease and license.

12. Incorporeal things may be rented.

13. Lease of a farm on shares.

IMPLIED RENTING.

14. In case a tenant remains with permission and pays rent after lease expires.

I5. Occupancy under an agreement for a lease.

16. Occupancy of land where there is no agreement to pay rent.

17. Where a purchaser at sheriff's sale elects not to take the tenant.

18. Where a tenant remains in possession after the end of his lease without consent.

I9. A tenant in possession under a void lease.

UNWRITTEN LEASES.

20. Act of 1772 , requiring writing.

Date of Lease.

21. Mistake or omission of date. 
The Names of the Parties. SECTION

22. Mistakes or omissions of names.

Leases by Agents.

23. The manner of signing and sealing a lease by an agent.

24. Ratification of a parol lease void under the statute of frauds.

25. An agent should have sealed authority to make a sealed lease.

26. Agents sealing leases without authority personally liable.

27. Leases by agents not under seal.

28. Parol evidence admissible to prove a lease not under seal as principal's.

29. Agents making leases in their own names deprive their principals of their rights as landlords.

30. When agent makes a lease without disclosing his principal, tenant cannot deny that the agent is not landlord.

3I. Agent without authority in writing may make lease not over three years.

32. Personal liability of agents for their contracts when they do not disclose their principals.

\section{Leases by and to Partners.}

33. Leases by partners should be sealed by all the partners.

34. Lease by one partncr of partnership property.

35. Partners taking leases in their own names for the firm, hold in trust for the firm.
Leases by Minors and GuardIANS.

SECTION

36. Minors' leases.

37. Leases by guardians.

LEASES By AND to MARRIed Women.

38. Power to lease under act of 1893.

39. Leases to married women.

Leases by Tenants for Life.

40. Lease must terminate at death.

Leases by and to Corporations.

4I May makc leases as natural persons.

42. May contract without writing.

43. Leases to foreign corporations.

44. Officers must be authorized to lease.

45. Corporation . cannot disable itself from performing public duties by a lease.

46. Corporate seal not necessary to hold a corporation in assumpsit.

47. Corporation may ratify agent's acts.

Leases by Tenants in Common.

48. May make joint or separate leases.

49 When a joint lease is made by tenants in common they must sue jointly.

50. Liability of tenant in common to pay his co-tenants not in possession.

Leases by Trustees and ExECUTORS.

51. Powers of trustees limited by the trusts. 
SECTION

52. Administrator cannot lease.

53. Until real estate is sold to pay debts the rents go to heirs or devisees.

54. An executor, unless he is made a trustee of real estate, cannot lease the same.

55. In case executors have a mere power to sell real estate.

56. In case of a trust to sell, but not to rent.

57. Power of trustees to agree to a renewal of lease.

58. Case of personal liability of an executrix under a lease.

59. Assignee for the benefit of creditors cannot lease.

\section{Description of Property RENTED.}

60. Not necessary to particularly describe premises in a lease.

6I. Ambiguous description supplied by evidence outside of the lease.

62. List of furniture should be annexed to lease.

63. Intention of what is leased, from actual use.

64. Case of property described as on the wrong corner.

65. Exceptions and reservations in leases.

66. Impiled grant of things necessary for the use of property.

67. Authority of landlord to enter after he has leased.

TERM OF A LEASE.

68. Estate for years.

69. Estate at will.

70. Tenant from year to year.

7I. Tenancy from quarter to quarter, from month to month, etc.

72. Perpetual leases.

73. Lease without a term stated.
SECTION

74. Tenancy from year to year by express agreement.

75. Term of tenancy implied by the payment of rent.

76. Landlord may elect to treat tenant holding over after lease as tenant or trespasser.

77. Tenant by the month may terminate lease at end of any month.

78. A lease from year to year, at the pleasure of the parties, a continuous lease.

79. The beginning and end of a lease.

8o. Continuation of lease at option of tenant.

81. Agreements for extension of terms and options.

RENT.

82. In what payable.

83. What rent may issue out of.

84. Interest on rent.

85. When no time fixed for the payment of rent.

86. Rent due after a sale.

87. Custom in Philadelphia to apportion rent.

88. A tenant bound by his covenant to pay rent, although he assigns lease.

89. Rent due landlord before he dies goes to his executor as personal property.

90. Rent due after death of lessor goes to his heir or devisee.

9I. An agreement of tenant to pay assessments.

92. Notice to lessor on contingency releasing lessee.

93. A landlord leaving a number of children, each child is entitled to his or her share.

94. Apportionment of rent in case of sale of reversion by landlord in parts. 
SECTION

95. Rent payable in advance upon contingency.

96. Tenant bound by his covenant to pay rent though property is burned.

97. Instances of losses to tenants for the want of an exemption from the payment of rent in case of fire.

98. Rents made payable to tenant for life apportioned under act of 1834 .

99. Rent payable in grain, etc., apportioned under act of 1834.

100. When rent is payable in grain, it is not due until delivered.

10I. Interest of landlord in share of grain cannot be taken in execution before severance.

102. Good-will of demised premises.

Covenants.

I03. Covenants running with the land.

I04. Implied covenants run with the land.

IC5. When covenants run with the land.

106. Assignees bound by covenants running with the land.

107. Examples of covenants running with the land.

108. Covenant to pay rent.

109. Covenants not to assign or underlet.

II0. Are construed strictly.

III. An assignment by law not a breach.

I12. Covenant as to use and occupancy.

II3. Landlord not bound to repair.

II4. The repairs a tenant is bound to make.
SECTION

II5. Express covenant of tenant to repair.

II6. Tenant is not bound by his covenant to repair injuries by act of God or public enemies.

II7. Tenant cannot charge landlord for permanent repairs made without his authority.

II8. Agreement of landlord to repair minor to that of tenant to pay rent.

I19. Measure of damages when landlord breaks his agreement to repair.

120. Tenant not relieved from loss in business during repairs.

12I. The covenant that improvements shall remain should be guarded against by the tenant as dangerous.

122. Definition of the word "improvement."

123. Covenant of landlord to sell to tenant.

124. Covenant for re-entry.

125. Requisites before entry.

126. There must not be a breach of the peace in making entry.

127. In Pennsylvania a re-entry is not necessary for a forfeiture.

128. Waiver of forfeiture.

129. Amicable action and confession of judgment in ejectment.

I30. If tenant has not paid his rent punctually he must be warned before entry of the judgment for non-payment.

I3I. For a purchaser to have benefit, the lease should be assigned.

132. No appeal to Supreme Court allowed.

133. Position of under-tenants. 
TABLE OF CONTENTS.

SECTION

134. Possession by those holding paramount title.

135. Implied covenant for quiet possession.

136. Implied covenant to protect tenant against paramount claims.

137. Implied covenant to use property in tenant-like manner.

138. Covenants as to farming.

Inability of Tenant to DisPUte the Title of his LANDLORD.

139. The rule and its operation.

140. Liability of tenant to forfeit his lease.
SECTION

I41. Case of collusion with tenant.

142. Case of fraud by the landlord.

Sealing and Execution of Lease, Stamps and ReCORDING.

143. Where landlord does not sign lease.

144. Where tenant does not sign lease.

I45 Kind of seal.

I46. Witnesses required.

147. Erasures and Interlineaations.

148. Stamps on leases.

149. Recording.

\section{CHAPTER II.}

FIXTURES.

PAGE 5I.

SECTION

150. Domestic fixtures.

15I. Trade fixtures.

152. Agricultural fixtures.

153. Fixtures not removed at the end of lease.

I54. Tenant's fixtures liable to execution.
SECTION

155. Notice to landlord upon constable's sale of a house as a trade fixture.

156. The duty of placing fire escapes in Philadelphia.

\section{- CHAPTER III.}

\section{SECURITY FOR RENT.}

PAge 56.

SECTION

157. Where surety is liable to be sued at once.

158. Covenant of suretyship runs with the land.

159. Tenant bound to exonerate surety.
SECTION

160. Position of surety in case of a tenant holding over.

161. Alteration of lease as it affects surety.

162. Discharge of surety by variation of lease. 
SECTION

163. Discharge of surety if landlord allows goods distrained to be removed.

164. Demand of rent by landlord.
SECTION

165. Discharge of surety by giving time.

166. Surety liable under a void lease.

\section{CHAPTER IV.}

\section{TRANSFERS OF INTERESTS OF LANDLORDS IN DEMISED}

\section{PREMISES.}

\section{Page 60.}

SECrION

167. By a sale and conveyance of the demised premises.

168. $\mathrm{By}$ an assignment of the landlord for the benefit of creditors.

169. By a conveyance to a trustee to collect rents, etc.

170. By a judicial sale.

171. Notice of affirmation of lease to be given to tenant.
SECTION

172. When lease antedates incumbrance, lease preserved.

173. When rent is paid in advance.

174. Rent before and after date of sheriff's deed.

175. The right of a purchaser at an orphans' court sale to rents or possession.

176. Transfer by the will of the landlord.

I77. Transfer by descent.

\section{CHAPTER V.}

\section{TRANSFERS OF INTERESTS OF TENANTS IN DEMISED PREMISES.}

Page 71 .

Assignment of Lease by TenANT AND UNDERLETTING.

SECTION

178. Leases not to be assigned except by writing.

179. Difference between assignments and underletting.

180. Position of under-tenant.

181. Power of tenant to assign or underlet.

182. Tenant bound to pay rent after he assigns his lease.
SECTION

183. Assignee liable as long as he holds title.

184. Implied indemnity of assignee.

185. Implied indemnity of tenant to under-tenant.

\section{AssignMent OF Lease When} Tenant Dies.

186. A lease a part of decedent's assets. 
SECTION.

187. When representatives become personally liable.

\section{Lease in CASE of an AsSignment} FOR THE BENEFIT OF Creditors.

188. Assignee for the benefit of creditors has the right to accept lease or not.

189. Landlord's preference under
SECTION

the act of 1891 , in case of assignments for the benefit of creditors.

190. Agreement of assignee with sheriff for sale of goods.

I9I. Liability of assignee for rent.

Sheriff's Levy and Sale of A LEASE.

192. Practice as to levy and sale.

\section{CHAPTER VI.}

\section{POWERS OF TENANT AND LANDLORD TO MORTGAGE.}

\section{PAGE 77.}

SECTION

193. Powers under the act of 1855 .

194. Lease must be recorded.

195. Machinery put in after mortgage.

196. Mortgage a breach of covenant not to assign.

197. The act is not restricted to mining leases.
SECTION

I98. Fixtures and machinery cannot be removed without consent of mortgagee.

199. Act of 1853 as to mortgages of mines.

200. Act of 1891 as to mortgages of ores, etc.

201. Mortgages of rentals or royalty.

\section{CHAPTER VII.}

THE RECOVERY OF POSSESSION OF DEMISED PREMISES UNDER THE ACT OF APRIL 3, I830, FOR THE NON-PAYMENT

\section{OF RENT.}

\section{PAGe 80.}

SECTION

202. The act of 1830 .

203. Who may have the benefit of the act.

204. The rent due must be certain. 205. The notice to quit.

206. By whom notice can be given.
SECTION

207. To whom notice should be given and manner of service.

208. Payment of rent on removal. 209. The complaint.

2I0. Summons.

2II. The service of the summons. 
SECTION

212. The hearing.

2I3. The necessary proof.

2I4. The judgment.

2I5. Appeal.
SECTION

216. Certiorari.

217. The execution.

218. Appeal to Supreme Court.

\section{CHAPTER VIII.}

PROCEEDINGS TO OBTAIN SECURITY FOR RENT OR POSSESSION WHEN TENANT REMOVES FROM THE DEMISED

PREMISES, IN PHILADELPHIA.

PAGE 89.

SECTION

219. Act of March 25, 1825 .

220. Tenant must remove.

22I. Notice must be signed by landlord or his agent.
SECTION

222. Complaint must show a lease for years.

223. Tender of rent.

\section{CHAPTER IX.}

\section{COLLECTING RENTS.}

PAGE 92.

\section{SECTION}

224. Jurisdiction of justices of the peace, etc.

225. The hearing.

226. Suits in court.

227. Practice in equity as to receivers collecting rents.

228. Collection of rent due during administration of receivers.

229. Loss of rents collected by receiver from sub-tenants.

230. Recovery of rent in case of death of tenant.

23I. Landlord to present claim to the orphans' court.

232. Collection of rent in case of bankruptcy.

233. Rent under the bankrupt act of 1898 not apportioned.
Rights to Rent from Sheriff's Sales of Personal PropERTY.

SECTION

234. Act of 1836 .

235. Rent apportioned.

236. Landlord should notify sheriff of his claim.

237. Note taken no waiver of claim.

238. The goods must have been liable to distraint.

Equitable Relief to a Tenant in CASE ReNT is CLAIMED by Two Adverse Parties.

239. The nature of the proceeding. 
Preference of Wages over RENT.

\section{SECTION}

240. Act of April 9, 1872.

24I. The claim for wages may be sold and assigned.
Collection of Rent by AtTACHMENT.

SECTION

242. Liability of rent due to be attached by an attachmentexecution.

243. Liability of tenant in case of foreign attachment against the landlord.

\section{CHAPTER X.}

\section{DISTRAINT FOR RENT.}

PAGE IOI.

SECTION

244. Act of March 2I, I772, regulating distraints for rent.

245. Distraint after termination of lease.

246. Distraint by lessor who has conveyed.

247. Distraint by executors and administrators.

248. Distraint by an assignee of the reversion.

249. Distraint by joint tenants.

250. Distraint by tenants in common.

251. Distraint by guardians.

252. Distraint by receivers.

253. Distraint by heirs, devisees, etc.

254. What rent may be distrained for.

255. Goods liable to distress.

256. Goods privileged from distress.

257. Authority given to distrain.

258. Penalty for distraining when no rent is due.

259. Distraining for more rent than is due.

260. Entering premises to make a distraint.

26r. Distraining upon the goods.
SRCTION:

262. Rescue of goods distrained.

263. Interference with distraint proceedings.

264. Unreasonable or excessive distraint.

265. Placing watchman.

266. Leaving goods on premises.

267. Notice, etc., to tenant.

268. Tender of rent.

269. Replevin.

270. The time for issuing the writ.

27I. Order for the writ.

272. Entering security.

273. The pleadings.

274. Trial and judgment.

275. Replevin the proper remedy for illegal distraint upon stranger's goods.

276. Liability of landlord for distraining on goods of a stranger.

277. Appraisement of the goods.

278. Sale of goods.

279. Manner of sale.

280. Exemption of rented pianos.

281. Exemption of sewing machines.

282. Liability of goods sold according to instalment plan. 
SECTION

283. Three hundred dollars exemption law.

284. Appraisers to be appointed.

285. Under-tenants cannot claim benefit.

286. Refusal of exemption.

287. Who can claim exemption.

288. When claim should be made.

289. Request for appraisement.

290. How claim is to be made when tenant absent.
SECTION

291. Right to distrain on property fraudulently removed under act of 1772 .

292. Goods of a stranger not to be followed.

293. Goods sold are exempt.

294. Rent must be due at time of removal.

295. Right to collect rent not due under act of 1825 .

\section{CHAPTER XI.}

LIABILITY OF GOODS OF TENANT FOR TAXES OF LANDLORD.

PAGE 124.

SECTION

296. Act of April 19, 1883, provid-

ing for a right to distrain

on tenant's goods for taxes

in cities of the first class.

\section{CHAPTER XII.}

\section{RIGHTS TO CROPS AND EMBLEMENTS.}

PAGE 126.

SECTION

297. Definition of emblements.

298. Growing grass.

299. Things not of annual growth.

300. Right lost by forfeiture of lease.

301. Definition of waygoing crop.

302. Who entitled to the crop.

303. Straw included.

304. Must be fall grain.

305. Crop may be sold by tenant.

306. The protection of the crop.

\section{SECTION}

307. Crop in case of execution.

308. Definition of a cropper.

309. Landlord not entitled to grain as rent until delivered.

3ro. Under orphans' court sale, crops as rent pass to purchaser.

3ri. Crops payable as rent, growing at the death of landlord, go to heirs. 


\section{CHAPTER XIII.}

POWER OF TENANT TO BIND OWNER'S PROPERTY FOR MECHANICS' LIENS.

PAGE I 30.

SECTION;

3I2. In what cases properties are bound.

313. Act of May 18, 1887, re-
SECTION

quiring written consent of landlord for tenant to bind premises for repairs, etc.

\section{CHAPTER XIV. \\ INSURANCE BY TENANTS. \\ PAge I33. \\ SECTION \\ 314. Such insurance distinguished \\ from other insurance.}

\section{CHAPTER XV.}

\section{EVICTION.}

\section{Page 134.}

SECTION

315. Eviction in part does not suspend the whole rent when tenant remains.

316. Landlord taking possession of ruins after a fire.

317. Physical expulsion not necessary.

318. Where tenant takes possession in case of tenant's desertion.
SECTION

319. Landlord using a way.

320. Operation against current rent.

321. Eviction by an injunction.

322. No eviction by conduct not depriving tenant of the use of property.

323. Waiver of eviction by paying rent. 


\section{CHAPTER XVI.}

\section{SURRENDER.}

PAGE 138.

SECTION

324. Parol surrender of lease for more than three years.

325. Surrender must be accepted.

326. Evidence of acceptance.

327. Surrender to agent.

328. Effect of surrender on request.
SECTION

329. Surrender by a tenant does not extinguish the term of a sub-tenant.

330. Effect of silence of landlord upon a surrender.

\section{CHAPTER XVII.}

FORCIBLE ENTRY AND DETAINER.

PAGE 14I.

SECTION

331. Act of assembly relating to same.

332. Must be a breach of the peace.

333. Forcible detainer.
SECTION

334. Tenant holder-over not liable for forcible detainer.

335. To constitute forcible entry or detainer there must be violence.

\section{CHAPTER XVIII.}

PROCEEDINGS TO RECOVER POSSESSION OF DEMISED PREMISES AT THE END OF THE TERM UNDER THE ACT OF

\section{MARCH 2I, I772.}

PAGE 145.

SECTION

336. Words of the act.

337. Who are entitled to the benefit of the act.

338. Rent must be certain.

339. Notice to quit.

340. Service of notice to quit.

341. Complaint.

342. Venire to the sheriff.
SECTION

343. Service of summons.

344. Proceedings before the jury. 345. Proceedings when the title is disputed.

346. Finding of the jury, judgment and writ for possession. 
SECTION

347. Proper form for the record.

348. Removal by certiorari.

349. What can be shown at hearing upon certiorari.
SECTION

350. Appeal to the Supreme Court.

351. Tenant may traverse the inquisition in an action of ejectment.

\section{CHAPTER XIX.}

PROCEEDINGS TO RECOVER POSSESSION AT THE END OF THE LEASE UNDER THE ACT OF DECEMBER I4, I863.

PAGE 155.

SECTION

352. Words of the act.

353. Power of justice of the peace extended to aldermen.

354. Act extended to assignees.

355. Appeal will be a supersedeas in Philadelphia.

356. Tenancy to be established by parol or written agreement.

357. Notice to quit.

358. Tenant not bound to give notice to quit.

359. Notice given by assignee of lease.

360. Verbal notice.

$36 \mathrm{r}$. Time of giving notice.
SECTION

362. No limitation for landlord to proceed on notice.

363. Notice to quit may be waived.

364. Service of notice for possession.

365. Complaint.

366. Summons.

367. Service of summons.

368. Hearing.

369. Warrant for possession.

370. Appeal.

37. Judgment.

372. Record.

373. Certiorari.

374. Appeal to Superior Court.

\section{CHAPTER XX.}

PROCEEDINGS TO RECOVER POSSESSION IN PHILADELPHIA ON

\section{A LOST LEASE.}

PAGE 167.

SECTION

375. Act of February 28, I 865. 


\section{CHAPTER XXI.}

\section{NEGLIGENCE AS TO RENTED PROPERTY.}

Page I69.

SECTION

376. Defects before renting.

377. Where property rented is unfit for use.

378. Landlord employing plumber.

379. Liability of owners.

380. Landlord and tenant may both be liable.

381. Liability in case of an open grate.

382. Landlord and tenant may sue at same time.

383. Where landlord interferes with tenant.

384. Where tenant injures property.

385. Liability between tenants.
SECTION

386. Liability depending upon obligation to repair.

387. Remedy in case tenant commits waste.

388. Act of 1822 as a remedy for waste.

389. Order to permit inspection of waste.

390. Writ of estrepement.

391. Remedy by suit for waste.

392. Remedy by an injunction for waste.

393. Liability of contractor for injury.

394. Liability for leakage from a cess-pool.

395. Liability for not repairing sidewalk.

\section{CHAPTER XXII.}

RIGHTS OF LANDLORDS AND TENANTS IN CASE RENTED PROPERTY IS TAKEN FOR PUBLIC USE.

PAGE I76.

SECTION

396. Constitutional provision.

397. Difference when state takes.

398. Damages awarded to landlords and tenants.

399. Party wall condemned and taken down by public authority.

400. Tenant can recover damages to building erected before ordinance for removal.
SECTION

401. Landlords and tenants may unite to recover damages for taking property for public use.

402. Land may be cultivated until possession taken.

403. Effect of taking on liability for rent.

404. What damages can be recovered. 


\section{CHAPTER XXIII.}

\section{FEES OF CONSTABLES, JUSTICES OF THE PEACE AND WATCH- MEN IN LANDLORD AND TENANT PROCEEDINGS.}

Page 180.

SECTION

405. The act of Feb. I7, I899, relating to fees of constables. 405*. The act of May 23, 1893, re-
SECTION

lating to the fees of justices and magistrates.

406. No provision in the act of 1899 for watchman.

\section{CHAPTER XXIV.}

\section{MINING LEASES.}

Page 184.

SECTION

407. Mining leases in Pennsylvania.

408. Mining right distinct from surface right.

409. Rights of tenant for life.

4IO. Rights of guardians to lease.

4II. Tenant bound to work mine.

412. Clause for re-entry necessary.

413. Incidental rights of mining tenant.

4I4. Right of support.

4I5. Loss of springs on surface.

4I6. Tenant cannot open mines.

4I7. Rent to be paid, though no clay be taken out, not damages.

418. No warranty of coal.

419. Relief in case of mistake.

420. Tenants taking partners.

42I. Forfeiture for not developing favored.

422. Manner of conveying in case of sales of minerals.

423. Questions as to whether there is a sale, a lease or right to take coal without a sale.
SECTION

424. Mining by tenants in common.

425. Oil and gas leases.

426. Right to mine for oil or gas is necessarily exclusive of the right of the landlord to mine.

427. Liability to pay compensation in case of exhaustion of mines.

428. Obligation to drill through land worthless for oil or gas.

429. Mortgages of mineral leaseholds.

430. Perpetual lease of are lands.

431. Options to drill or to pay rent.

432. Provisions for the forfeiture of an oil or gas lease for the benefit of the lessor only.

433. Right of mining tenants to pollute streams.

434. Liability for manufacturing coke and injuring crops, etc., of adjoining premises.

435. As to whether or not a min- 
SECTION

ing lease lias been forfeited for not opeiating.

436. Rights to make openings to reach coal.

437. Agreements for diligence in drilling and working for oil, etc.

438. In agreements for coal leases time is of the essence of the contract.

439. Relief against forfeiture of an oil and gas lease for nonpayment of rent.

440. Partnership in mineral leaseholds.

441. Relief against forfeiture of mining leases.

442. A lease for exploration for oil ceases when exploration finished.

443. Interest on royalties.
SECTION

444. Tenant will not be compelled in equity to test land for oil or gas if there is no fraud.

445. Covenants to pay royalties run with the land.

446. When lessee to follow his own judgment in sinking additional wells.

447. The meaning of the phrase, "to continue so long as oil or gas are produced in paying quantities."

448. Necessity for having oil leases recorded.

449. Jurisdiction in equity for account of gas, etc.

450. Rent may be payable in oil or gas.

451. Liability of assignee of an oil or gas lease for the payment of royalties.

\section{CHAPTER XXV.}

PRACTICAL DIRECTIONS IN MATTERS RELATING TO THE

\section{RENTING OF PROPERTY.}

PAGE 199.

SECTION

452. Examination of the property.

453. See what neighbors can do in diminishing the value of demised premises.

454. Inquiries of landlord before renting.

455. False representations by lessee.

456. See if demised premises in the city of Philadelphia are liable to be taken for public use.

457. Examination of the title of the landlord.
SECTION

458. Examination as to encumbrances.

459. See if lease can be destroyed by an orphans' court sale.

460. See if there is a liability for a distraint for taxes.

46r. Obtaining rights for a show case.

462. Obtaining sign rights by tenant.

463. Provisions in case of fire or other casualty.

464. Directions for making rents certain for distraint and possession. 
SECTION

465. Directions in case of an underletting.

466. Giving rights to tenants to purchase.

467. Fixtures of tenant to be protected in cases of renewed leases.

468. Making a penalty to be paid as rent.

469. Directions in taking assignments of leases.

470. Provisions prohibiting parol testimony to affect written leases.

47r. Restrictions as to the use of demised premises.

472. Making rent due in advance by occurrences after the lease.

473. Providing against the liability of the owner for nuisances.

474. Prevention of defences being waived by paying rent or other action.

475. Prevention of the termination of farm leases by death of tenant.

476. Provisions for amicable ejectments.

477. Providing for distraint after removal of tenant.

478. Giving sub-tenants the benefit of the exemption law.

479. Providing for surety in cases of extensions of lease.

480. Getting the consent of the surety to alter lease.

48r. Extension of right to terminate lease to assignees, etc.

482. Danger of landlord losing his right to rent by the nonperformance of an entire contract.

483. Cautions in preparing agree-
SECTION

ments for the extension of term and for options.

484. Necessity of a consideration for an agreement to change the terms of a lease.

485. Protecting landlord in farm leases.

486. Making the payment of taxes, charges, etc., as rent.

487. Necessity of reading leases.

488. Protecting fire insurance from conduct of tenant.

489. Distinguishing between a lease and sale in granting mining rights.

490. Necessity of a particular description of the extent of a right to mine.

49r. Ascertaining if any old mining leases are outstanding.

492. Protection to landlord who reserves the surface in a lease to mine.

493. Binding remainderman in case of a lease by tenant for life.

494. Necessity of recording oil lease when tenant does not take possession.

495. Necessity for having time fixed for delivery of landlord's share of crops.

496. Protection of parties in agreements to pay for taxes, charges, assessments, etc.

497. Dangers in using clause that landlord may change terms of lease.

498. In case of doubtful construction, the tenant favored.

499. Fixing a time for the tenant to perform an agreement to make improvements.

500. Protecting landlord's right to 
SECTION

tenant's fixtures at the end of the lease from levy, etc.

501. If an assignee assigns his lease and retains an interest he will remain liable.

502. Necessity of having a clause for forfeiture for a breach of a covenant not to assign.

503. Guarding against the breach of trifling covenants giving the right to recover possession.

504. In case a tenant agrees to use
SECTION

or not to use demised premises for a certain business or purpose.

505. Danger of there being a breach of a covenant not to assign lease by taking a partner.

506. Necessity for a description to locate premises in leases or amicable ejectments.

506*. Giving right to distrain off the demised premises.

\section{CHAPTER XXVI.}

FORMS.

PAGE 238.

SECTION

507. A lease.

508. Farm lease.

509. Farm lease on shares.

510. Farm lease on shares, short form.

5II. Covenant that lessee shall fallow the land and mow but once a year, etc.

512. Covenant that lessee may dispose of hay and straw.

513. Covenant to lay down part of the ground with clover, etc.

514. That the lessee shall use the hay, dung, etc., on the premises.

5I5. Fire clause for farm lease, No. I.

516. Fire clause for farm lease, No. 2.

517. Fire clause for a dwelling.

518. Fire clause for a business property.

519. To protect against assignment of lease.
SECTION

520. For insertion after ejectment clause.

521. Giving an option to purchase.

522. Surety for tenant.

523. Assignment of lease.

524. Surrender of lease.

525. Distress warrant.

526. Notice of distraint.

527. Affidavit of appraisers and appraisement.

528. Consent of tenant to permit distrained goods to remain.

529. Notice of constable's sale.

530. Claim for benefit of exemption law.

531. Summons of appraisers.

532. Affidavit of appraisers and election.

533. Appraisement of exempted goods.

534. Amicable action and judgment in ejectment.

535. Notice to quit for non-pay- 
TABLE OF CONTENTS.

xxiii

SECTION

ment of rent under act of I830.

536. Complaint.

537. Summons.

538. Writ of restitution.

539. Record.

540. Notices to quit at end of lease.

54I. Complaint for possession under act of 1772 .

542. Precept to the sheriff.

543. Inquisition.
SECTION

544. Record.

545. Summons to third party claiming title.

546. Complaint for possession under act of 1863 .

547. Summons.

548. Record.

549. Writ of restitution.

550. Notice in case of lost lease. 551. Second notice.

552. Notice when tenant is unable to answer first notice. 



\section{THE LAW OF}

\section{LANDLORD AND TENANT.}

\section{CHAPTER I.}

\section{LEASES.}

PAGe 5.

Agreements For a Lease. SECTION

I. Directions for preparing.

2. A specific performance will be decreed.

3. Damages for a breach of an agreement for a lease.

4. Where a tenant under a parol agreement for a lease is let into possession and makes improvements.

5. A lease completed by an actual entry of the tenant.

Parol Evidence AS APPlied to WRITTEN AGREEMENTS.

6. Admissible in case of fraud, accident or mistake.

7. Admissible in some other cases.

8. Agreement in writing to exclude verbal understandings, etc.

\section{Construction of Leases.}

9. Rules for construction.
The Nature of a Lease.

SECTION

10. Definition of a lease.

II. Distinction between a lease and license.

12. Incorporeal things may be rented.

13. Lease of a farm on shares.

IMPLIED RENTING.

14. In case a tenant remains with permission and pays rent after lease expires.

I5. Occupancy under an agreement for a lease.

16. Occupancy of land where there is no agreement to pay rent.

I7. Where a purchaser at sheriff's sale elects not to take the tenant.

18. Where a tenant remains in possession after the end of his lease without consent.

19. A tenant in possession under a void lease. 
UNWRITTEN LEASES.

SECTION

20. Act of 1772 , requiring writing.

Date of Lease.

21. Mistake or omission of date.

The Names of the Parties.

22. Mistakes or omissions of names.

Leases by Agents.

23. The manner of signing and sealing a lease by an agent.

24. Ratification of a parol lease void under the statute of frauds.

25. An agent should have sealed authority to make a sealed lease.

26. Agents sealing leases without authority personally liable.

27. Leases by agents not under seal.

28. Parol evidence admissible to prove a lease not under seal as principal's.

29. Agents making leases in their own names deprive their principals of their rights as landlords.

30. When agent makes a lease without disclosing his principal, tenant cannot deny that the agent is not landlord.

31. Agent without authority in writing may make lease not over three years.

32. Personal liability of agents for their contracts when they do not disclose their principals.

Leases by and to Partners.

33. Leases by partners should be sealed by all the partners.
SECTION

34. Lease by one partner of part. nership property.

35. Partners taking leases in their own names for the firm, hold in trust for the firm.

Leases by Minors and Guard. IANS.

36. Minors' leases.

37. Leases by guardians.

Leases BY AND TO MARRIED WOMEN.

38. Power to lease under act of 1893.

39. Leases to married women.

Leases by Tenants for Life.

40. Lease must terminate at death.

LEASES BY AND to CORPORATIONS.

4I May make leases as natural persons.

42. May contract without writing

43. Leases to foreign corporations.

44. Officers must be authorized to lease.

45. Corporation cannot disable itself from performing public duties by a lease.

46. Corporate seal not necessary to hold a corporation in assumpsit.

47. Corporation may ratify agent's acts.

Leases by Tenants in Common.

48. May make joint or separate leases.

49 When a joint lease is made by tenants in common they must sue jointly.

50. Liability of tenant in common to pay his co-tenants not in possession. 
Leases - by Trustees and ExECUTORS.

SECTION

5I. Powers of trustees limited by the trusts.

52. Administrator cannot lease.

53. Until real estate is sold to pay debts the rents go to heirs or devisees.

54. An executor, unless he is made a trustee of real estate, cannot lease the same.

55. In case executors have a mere power to sell real estate.

56. In case of a trust to sell, but not to rent.

57. Power of trustees to agree to a renewal of lease.

58. Case of personal liability of an executrix under a lease.

59. Assignee for the benefit of creditors cannot lease.

\section{Description of Property RENTED.}

6o. Not necessary to particularly describe premises in a lease.

6I. Ambiguous description supplied by evidence outside of the lease.

62. List of furniture should be annexed to lease.

63. Intention of what is leased, from actual use.

64. Case of property described as on the wrong corner.

65. Exceptions and reservations in leases.

66. Impiled grant of things necessary for the use of property.

67. Authority of landlord to enter after he has leased.

\section{TERM OF A LEAsE.}

68. Estate for years.

69. Estate at will.

70. Tenant from year to year.
SECTION

7I. Tenancy from quarter to quarter, from month to month, etc.

72. Perpetual leases.

73. Lease without a term stated.

74. Tenancy from year to year by express agreement.

75. Term of tenancy implied by the payment of rent.

76. Landlord may elect to treat tenant holding over after lease as tenant or trespasser.

77. Tenant by the month may terminate lease at end of any month.

78. A lease from year to year, at the pleasure of the parties, a continuous lease.

79. The beginning and end of a lease.

80. Continuation of lease at option of tenant.

8I. Agreements for extension of terms and options.

Rent.

82. In what payable.

83. What rent may issue out of.

84. Interest on rent.

85. When no time fixed for the payment of rent.

86. Rent due after a sale.

87. Custom in Philadelphia to apportion rent.

88. A tenant bound by his covenant to pay rent, although he assigns lease.

89. Rent due landlord before he dies goes to his executor as personal property.

90. Rent due after death of lessor goes to his heir or devisee.

9I. An agreement of tenant to pay assessments.

92. Notice to lessor on contingency releasing lessee.

93. A landlord leaving a number 
SECTION

of children, each child is entitled to his or her share.

94. Apportionment of rent in case of sale of reversion by landlord in parts.

95. Rent payable in advance upon contingency.

96. Tenant bound by his covenant to pay rent though property is burned.

97. Instances of losses to tenants for the want of an exemption from the payment of rent in case of fire.

98. Rents made payable to tenant for life apportioned under act of 1834 .

99. Rent payable in grain, etc., apportioned under act of 1834 .

100. When rent is payable in grain, it is not due until delivered.

IOI. Interest of landlord in share of grain cannot be taken in execution before severance.

102. Good-will of demised premises.

\section{Covenants.}

ro3. Covenants running with the land.

ro4. Implied covenants run with the land.

105. When covenants run with the land.

106. Assignees bound by covenants running with the land.

107. Examples of covenants running with the land.

108. Covenant to pay rent.

rog. Covenants not to assign or underlet.

I Io. Are construed strictly.

III. An assignment by law not a breach.
SECTION

I12. Covenant as to use and occupancy.

Ir3. Landlord not bound to repair.

II4. The repairs a tenant is bound to make.

rr5. Express covenant of tenant to repair.

I16. Tenant is not bound by his covenant to repair injuries by act of God or public enemies.

117. Tenant cannot charge landlord for permanent repairs made without his authority.

II8. Agreement of landlord to repair minor to that of tenant to pay rent.

II9. Measure of damages when landlord breaks his agreement to repair.

I20. Tenant not relieved from loss in business during repairs.

121. The covenant that improvements shall remain should be guarded against by the tenant as dangerous.

122. Definition of the word "improvement."

123. Covenant of landlord to sell to tenant.

124. Covenant for re-entry.

125. Requisites before entry.

126. There must not be a breach of the peace in making entry.

127. In Pennsylvania a re-entry is not necessary for a forfeiture.

128. Waiver of forfeiture.

129. Amicable action and confession of judgment in ejectment.

r30. If tenant has not paid his rent punctually he must be warned before entry of the judgment for non-payment. 
SECTION

I3I. For a purchaser to have benefit, the lease should be assigned.

132. No appeal to Supreme Court allowed.

133. Position of under-tenants.

134. Possession by those holding paramount title.

135. Implied covenant for quiet possession.

136. Implied covenant to protect tenant against paramount claims.

137. Implied covenant to use property in tenant-like manner.

138. Covenants as to farming.

Inability of Tenant to DisPUte the Title of his LANDLORD.
SECTION:

I39. The rule and its operation.

140. Liability of tenant to forfeit his lease.

I4r. Case of collusion with tenant.

142. Case of fraud by the landlord.

Sealing and Execution of Lease, Stamps and ReCORDING.

I43. Where landlord does not sign lease.

144. Where tenant does not sign lease.

$145 \mathrm{Kind}$ of seal.

I46. Witnesses required.

147. Erasures and Interlineaations.

148. Stamps on leases.

149. Recording.

\section{AGREEMENTS FOR A LEASE.}

Directions for Preparing.

I. It is sometimes difficult to distinguish between a lease and an agreement for a lease. The intention if it can be found will govern. In case of any doubt the language will be considered so as to discover indications of intent. The immediate transfer of possession and the immediate payment of rent are strong indications of a present letting. The agreement for a lease should always be made plain so that there can be no question as to its character. The agreement for a lease should contain a minute of all the important terms to be incorporated therein, as otherwise only the usual covenants can be required. What are usual covenants may often be a question. It has been held that the lessor could not, as a matter of right, demand a covenant of the lessee not to assign or underlet without license, although according to present practice it might be held a usual covenant. When under an agreement of lease, a lease is prepared even in what may be considered, in certain localities as the usual manner, the 
tenant may possibly have the right to object to clauses often used. The tenant possibly might have the right to object to an amicable ejectment clause for instance. If trouble over the form of lease is anticipated, the proper form should be selected in the agreement.

\section{A Specific Performance will be Decreed.}

2. If the agreement for a lease is in writing and shows clearly the property to be rented and all necessary terms, an application may be made to a court of equity for a specific performance. If a person contracts to sell an estate or to grant a lease, a purchaser with notice of such contracts is liable to perform them. ${ }^{1}$

\section{Damages for a Breach of an Agreement for a Lease.}

3. A defendant agreed to lease to plaintiff a hotel for three years from the succeeding first of April. Before that date, the plaintiff bought many articles for the purpose of furnishing the hotel. He was not given possession. He sold those articles. He sold his house and personal property therein at vendue. When he failed to get the hotel he was without a home and was compelled to board. The court intimated that such evidence would be relevant as showing damage. $^{2}$ Plaintiff made a parol contract with defendant to lease certain premises for five years. The defendant refused to take them at the time agreed upon and they remained untenanted for a year, and plaintiff brought an action to recover damages therefor. Held, that the action would lie, but, as the proposed lease was for over three years, and was within the statute of frauds, the damages recovered could only be those which arose directly from the breach, but that the rent agreed upon could not be used as a measure of damages, for by the statute, the plaintiff was not entitled to them. ${ }^{3}$ The

I Notes to Le Neve $v$. Le Neve, 2 Leading Cascs in Equity (3 Am. Ed.), 135 .

2 Yeager $v$. Weaver, 64 Pa. 425.

3 Sausser $v$. Steinmetz, 88 Pa. 324; McCafferty $v$. Griswold, 99 Pa. 270. 
rule or measure of damages for the breach of a contract to Jease is the same as for a breach of a contract to sell land. A. bought of the tenant an unexpired lease upon an agreement with the landlord that he would renew it. The landlord and remainderman each refused to renew, and the landlord died before the expiration of the lease. Held, that the measure of damages in a suit by A., against the landlord's administrator was the price paid for the lease and its interest, and not the value of the contract. A purchaser is not entitled to any compensation for the fancied goodness of his bargain when the vendor is without fraud incapable of making title.

Where a Tenant under a Parol Agreement for a Lease is Let into Possession and makes Improvements.

4. Even when there is no writing and the proposed tenant is let into possession and makes valuable improvements upon the faith of such agreement, a court of equity will compel the execution of the lease agreed upon. ${ }^{5}$

\section{A Iease Completed by an Actual Entry of the Tenant.}

5. At common law no lease for years was looked upon as complete until an actual entry by the lessee; before such entry his right was called his interest in the term. When a lessor fails to deliver the premises acording to contract, the lessee has two remedies : either by a suit against the lessor on his covenant, or he may, if he think proper, enter and recover the term. In legal contemplation the right to possession is in the lessor as against a third person until the contract is consummated by the entry of the lessee. A notice by a lessor in possession of the premises that the lease is forfeited, is substantially a declaration that he will refuse to give the lessee possession of the land, and if the lessee assents to this action, and accepts a new lease from the lessor, he rescinds 
the former lease and terminates all his rights thereunder. $^{6}$

\section{PAROL EVIDENCE AS APPLIED TO WRITTEN AGREEMENTS.}

Admissible in Case of Fraud, Accident or Mistake.

6. The English rule that parol evidence is inadmissible to vary the terms of a written instrument has been said not to exist in this state, but it has also been said that perhaps it would be more accurate to say that the rule has been relaxed, for the guards which the court has thrown around the modification of the rule have, to some extent, preserved the rule itself. The cases in this state in which parol evidence has been allowed to contradict or vary written instruments may be classed under two heads.

First, Where there was fraud, accident or mistake in the creation of the instrument itself, and

Second, Where there has been an attempt to make a fraudulent use of the instrument in violation of a promise or agreement made at the time the instrument was signed, and without which it would not have been executed. ${ }^{7}$ Parol evidence is admissible to show a verbal contemporaneous agreement which induced the execution of a written obligation, though it may vary or change the terms of the writing, ${ }^{8}$ and this is so, although such oral stipulation was not omitted from the writing through fraud, accident or mistake. ${ }^{9}$ The agreement to change the written agreement must be shown by evidence that is clear, precise and indubitable, and this can only be done by the testimony of two witnesses, or of one witness, corroborated by circumstances equivalent to another. ${ }^{10} \mathrm{~A}$ written agreement may not be set aside on the

6 Gas Co. v. Phila. Co., 158 Pa. 317; Sennett $v$. Bucher, 3 P. \& W. 392.

7 Assn. v. Hetzel, 103 Pa. 507; Phillips v. Meily, 106 Pa. 536.

8 Assn. v. Hetzel, 103 Pa. 507. 9 Ferguson v. Rafferty, 128 Pa. 337.

Io Ferguson v. Rafferty, I28 Pa. 337; Thomas v. Loose, II4 Pa. 35. 
testimony of one party, contradicted by that of the other party. Yet where there are corroborating circumstances, or circumstances from which inference may be drawn, corroborative of the contemporaneous parol agreement the question should be submitted to the jury. ${ }^{11}$

\section{Admissible in some other Cases.}

7. Parol evidence is admissible to explain an ambiguity in a deed as to location of the land intended to be conveyed, ${ }^{12}$ and to explain and define the subject of a written agreement. Under such circumstances, evidence as to what took place between the parties in negotiating the lease is competent and relevant. ${ }^{13}$ Where an agreement in writing is expressed in short and incomplete terms, parol evidence is admissible to explain that which is, per se, unintelligible, such explanation not being inconsistent with the written terms. ${ }^{14}$ It has been held that the rule excluding oral testimony is applied to simple contracts in writing to the same extent and with the same exceptions as to specialties or contracts under seal. To ascertain the meaning of the words, parol evidence of extraneous facts and circumstances may be admitted. ${ }^{15}$ Parol evidence is admissible to show that, for a new consideration, a prior contract under seal was changed. ${ }^{16}$

Agreement in Writing to Exclude Verbal Understandings, etc.

8. In a case there. was the following clause: "It is agreed and understood that in writing and printing this paper contains the full and entire agreement between the parties thereto, and no verbal understanding is of any force and effect whatever, and it is not to be held binding." The justice remarked in this case that, "this at least warned the parties

II Smith v. Harvey, 40 W. N. C. 229. I2 Lulay v. Barnes, I72 Pa. 33I.

I3 Boice $v$. Zimmerman, 39 W. N. C. 306.

I4 Leggoe $v$. Mayer, 39 W. N. C. 247.

I5 I Greenleaf on Evidence, 4 Ed., \$§ 276, 282.

16 Wilgus $v$. Whitehead, $89 \mathrm{~Pa}$. 131; McCauley $v$. Keller, I30 $\mathrm{Pa} .53$. 
that the entire agreement, with all its terms and stipulations, is presumed to be set forth in the instrument." 17

\section{CONSTRUCTION OF LEASES.}

Rules for Construction.

9. The rule of construction which attaches more relative importance to the written than to the printed part of the contract, is often a very useful one, and is recognized in many of our cases, but neither this rule nor the rule that every man's grant is to be taken most strongly against himself relieves the court from the duty of reconciling the different parts of the contract if it can reasonably be done, and where the interpretation and effect of the written portion are themselves in question, the other portions of the contract, although printed cannot be disregarded. The intention of the parties is to be ascertained from the entire instrument, and not from particular words or phrases without reference to the context, and the instrument shall operate according to the intention, unless it be contrary to law. A deed must be so construed, if possible, that no part shall be rejected. The object of all construction is to ascertain the intent of the parties, and it must have been the intent to have some meaning to every part. It never could be a man's intent to contradict himself, therefore we should lean to such a construction as reconciles the different parts and rejects a conclusion which leads to contradiction. ${ }^{18}$ A mere use of technical words or phrases which have a definite legal signification cannot be allowed to defeat the contrary legal intention of the parties to a contract if that intention be made manifest from the whole contract. The words "demise," "lease," "mine-let," "lessors" and "lessees," have no bearing if the contract is, in effect, not a lease. ${ }^{19}$. Where the meaning is doubtful, the circumstances at the making of the instrument and the subsequent

I7 Thomas $v$. Loose, II $4 \mathrm{~Pa} .35$.

I9 Coal Co. $v$. Wright, 39 W. N. C. 146.

I8 Lane $v$. Nelson, $167 \mathrm{~Pa} .602$. 
acts of the parties are to be considered in determining the sense of the words. ${ }^{20}$ Tenant leased an academy for two weeks. He wrote to the company that he was unable to fulfill his contract and asked to have the lease cancelled. The company claiming to act as defendant's agent, and at his reqrest leased the academy for two nights of the tenant's term, being unable to dispose of the remaining portion; on his refusal to pay suit was brought. A defence was set up that by the custom of the theatrical profession, one month's notice of an inability to fulfill a lease was all that was necessary to cancel it. It was held that such a usage, if estabished, would be binding, if the parties contracted in reference to it. ${ }^{21}$

\section{THE NATURE OF A LEASE.}

\section{Definition of a Lease.}

Io. A lease is a contract for the possession and profits of lands and tenements on the one side, and a recompense of IEnt or other income on the other. It is essential that there nust be a lessor able to grant the land, a lessee capable of accepting the grant, and a subject-matter capable of being granted. It is the ordinary incident of every lease that the lessee shall pay a rent or consideration to the lessor for the use of the premises granted, but it is immaterial whether the IEnt is paid in money, or service, or in any stipulated article, such as grain or ore. ${ }^{22}$

\section{Distinction Between a Lease and License.}

II. A mere permission to occupy certain premises without pay, on condition of leaving whenever required by the owner to do so, does, not create a tenancy; for rent is the essence of a lease. Independent of the idea of a contract, a lease also

20 Lane $v$. Nelson, $167 \mathrm{~Pa} .602$; Berridge $v$. Glassey, I12 Pa. 442.

II Academy $v$. Birt, 26 W. N. C. 35I.

2 Kunkle $v$. Rifle Club, ro Phila. R. 52; 2 Addison on Contracts, §675. 
possesses the property of passing an interest, and partakes of the nature of an estate which, when limited to a certain period for the enjoyment of land, becomes a term for years. ${ }^{23}$

\section{Incorporeal Things may be Rented.}

I2. A way, etc., may be rented. ${ }^{24}$

\section{Lease of a Farm on Shares.}

I3. Jaquette agreed to farm the land of Brown, for which he was to have one-half the proceeds; each party furnishing one-half the seed, stock, poultry, hogs, etc., Jaquette was to find all the farming implements, the working stock, and all the requisite labor, and pay the road tax and one-half of all other taxes. He was also to submit a statement every three months, and make settlement. Held, that this agreement was a lease of the farm on shares and not a partnership. That the landlord had the right to distrain. That the tenant was not a mere cropper or a servant working land for produce. That the products of the farm could be reduced to certainty. ${ }^{23}$ Where a contract for hiring provides for a certain money compensation per day to the employé and a house to live in, the employe has no distinct right of possession as the house he occupies is that of the employer, and it cannot survive the living to which it is incidental, or under which it is part of the contract price for the service rendered. It is not necessary that the occupation of a house or apartments should be a necessary incident to the service to be performed in order that the right to continue in possession should end with the service. It is enough if such occupation is convenient for the purposes of the service and was obtained by reason of the contract of hiring. ${ }^{26}$

23 Taylor on Landlord and Tenant, § I4.

24 Thomas $v$. Railroad, 9 W. N. C. 65.

25 Brown $v$. Jaquette, 94 Pa. II3. 26 Bowman $v$. Bradley, I5I Pa. 35r. 


\section{IMPLIED RENTING.}

In Case a Tenant Remains with Permission and Pays Rent after Lease Expires.

I4. When a tenant for a year or for any term over a year, with the permission of the landlord, remains in possession of the demised premises after the expiration of the term, and pays rent, the law will imply a further renting from year to year, for the same rent and subject to all the agreements in the original lease as are applicable to the new situation, but not subject to agreements as to matters intended only to be performed during the original lease. ${ }^{27}$

\section{Occupancy under an Agreement for a Lease.}

I5. If a party occupy and pay rent under an agreement for a term, then, although such agreement may not operate to create the proposed term, either in consequence of its not amounting to a lease or not being a good execution of a power, yet the party so occupying and paying rent is considered as holding upon all the terms of the agreement not inconsistent with a tenancy from year to year, such as an obligation to repair, and the like. If rent is paid with reference to a yearly tenancy, the implied letting will be from year to year. When, however, the rent is paid monthly, the tenancy will, it seems, be presumed to be from month to month, as against a party who has refused to recognize the validity of the oral demise or accept a written lease in conformity with its terms. ${ }^{28}$

Occupancy of Land where there is no Agreement to Pay Rent.

I6. If a person occupies land by the permission of another, the law will presume a promise to pay a reasonable compensation, though none has been expressly fixed. In such cases the contract is deduced from the assent of the owner and

27 Phillips $v$. Monges, 4 Whar. R. 225; Diller $v$. Roberts, I3 S. \& R. 59. 28 Notes to Doe $v$. Bell, and Clayton $v$. Blakey, I Smith's Leading Cases, 186, 189, 192. 
the action of the occupant under it. But there is no basis for any implication of a contract to pay for the use of land where an occupant enters without any understanding with the owner and without his knowledge. ${ }^{29}$ The compensation is not rent, but an equivalent for rent, and it can be shown that the occupation has not been beneficial. ${ }^{30}$

Where a Purchaser at Sheriff's Sale Elects not to take the Tenan:

I7. When a purchaser at sheriff's sale elects to disaffirm a lease, he can claim for use and occupation until he obtains possession. ${ }^{31}$

Where a Tenant Remains in Possession after the End of his Leas? without Consent.

I8. A tenant holding over after his term, without permis-sion of his landlord, is liable for the use and occupation. ${ }^{32}$

\section{A Tenant in Possession under a Void Lease.}

I9. A tenant who is in possession under a void lease, or who is let into possession before the execution of the lease, is bound to pay for such occupancy. ${ }^{33}$

\section{UNWRITTEN LEASES.}

\section{Act of 1772, Requiring Writing.}

20. In Pennsylvania all leases not put into writing and signed by the parties making the same, or their agents, thereunto lawfully authorized by writing, have only the force and effect of leases from year to year, except all leases not exceeding the term of three years from the making thereof. ${ }^{34}$ The void lease will regulate the terms of the substituted interest. $^{35}$ A parol agreement between a landlord and a tenant in possession of the premises for a lease of the same for a

29 Brolasky $v$. Ferguson, $48 \mathrm{~Pa} .434$; Marlatt $v$. Marlatt, 4 Pennypacker R. 9 I.

30 Kline $v$. Jacobs, $68 \mathrm{~Pa} .57 . \quad$ 3I Assn. v. Frisdjen, 5 W. N. C. 318.

32 Bush v. Oil Co., 5 W. N. C. I43.

33 Stover $v$. Cadwallader, 2 Pennypacker R. II7.

34 Act of March 2I, I772. 35 Roberts' Dig. 317. 
term of three years, commencing one year after the date of the agreement, is void under the statute of frauds. The facts that the tenant was in possession, and that he made certain improvements in consideration of said lease, do not create a sufficient equity to take the case out of the operation of the statute. Counsel argued, that to take a parol contract out of the statute of frauds, possession must be taken in pursuance thereof, and that a previous and continuing possession will not have that effect. ${ }^{36}$ The decedent was in possession of the premises under a void lease for ten years. Under the statute of frauds this is to be considered a tenancy at will only; under the decisions in this state, a tenancy at will is to be considered as a tenancy from year to year. ${ }^{37}$ A provision in a written lease for five years, for an extension for a further period of five years on the same terms, at the option of the lessee, by notice in writing at least three months before the expiration of the first term, is not within the statute of frauds, as the term embraced in the renewal is created and defined by the lease itself. Under a lease of real estate for five years, executed under seal by the lessee alone, the latter entered and remained in possession. By a separate writing under seal, attached to the lease, the defendant became responsible for the lessee's covenants, for the full time in which the latter might retain possession thereunder. In such case, the legal effect of the lessor's omission to sign the lease, under the statute of frauds, had no bearing on the defendant's responsibility; for under the terms of his own contract, the defendant was liable as surety, so long as the lessee remained in possession of the premises under the terms of the lease. ${ }^{38}$

\section{DATE OF LEASE.}

Mistake or Omission of Date.

2I. The date of a lease is no part of its substance, and need not, in fact, be inserted; and, therefore, a mistake in the date

36 Whiting $v$. Opera Co., 88 Pa. I00; Wheeler $v$. Conrad, 6 Phila. 209.

37 Hey v. McGrath, 8I I/2 Pa. 310. $\quad 38$ Duffee $v$. Mansfield, 14I Pa. 507. 
will not vitiate the instrument. If there is no date or an impossible one the term will be considered as commencing from the delivery of the deed; unless some particular time for its commencement is therein specified. It is competent for either party to show that the delivery took place on a day different from that of the date. ${ }^{39}$

\section{THE NAMES OF THE PARTIES.}

\section{Mistakes or Omissions of Names.}

22. An initial between the christian and surname is no part of either. ${ }^{40}$ The omission or insertion of the middle name is not required but it is better to have the correct middle names in a lease, as they are requisites in a judgment upon a lease, to give proper notice, and their omission might result in an erroneous judgment. A mistake in the spelling of the name not materially different from the true name will not invalidate the instrument. ${ }^{41}$

\section{LEASES BY AGENTS.}

The Manner of Signing and Sealing a Lease by an Agent.

23. If an agent sign and seal a deed in his own name, it does not bind his principal, though it purports to be made between the other party and the principal by such agent; nor will the confirmation by the principal, short of sealing the deed, render him liable on it; and as the one party is not bound, so neither is the other. ${ }^{42}$ A lease by an agent should be in this way, viz.: A. B., by C. D., his attorney, and conclude, In witness whereof A. B., by his attorney, C. D., has hereunto set his hand and seal, etc.; and the agent in executing such a lease should sign the name A. B., his principal, opposite a seal and under the same sign his own name op-

39 Taylor's Landlord and Tenant, § 148.

40 Bratton $v$. Seymour, 4 W. 329; Paul v. Johnson, 9 Phila. 32.

$4 \mathrm{I}$ Taylor's Landlord and Tenant, § 149.

42 Bellas $v$. Hays, 5 S. \& R. 427. 
posite another seal as follows: By his attorney, C. D. ${ }^{43} \mathrm{~A}$ lease was signed by the agent of the owners, merely as agent, but reciting the names of the owners as his principals, and purporting to be a grant, not in his own right, but as agent. Held to be good. ${ }^{44}$

\section{Ratification of a Parol Lease Void under the Statute of Frauds.}

24. A lease of land in writing for seven years, by an authorized agent, may be ratified by the owner; but to avoid the effects of the statute of frauds and perjuries, the ratification must be in writing; a parol ratification gives to the tenant an estate from year to year.. ${ }^{45}$

\section{An Agent should have Sealed Authority to make a Sealed Lease.}

25. An agent, in order to seal a deed, must have sealed authority from his principal. For example, an agreement was signed and sealed "Garner," and also "William Irwin (seal), by agent $\mathrm{McH} ., "$ and it was held that, there was no sealed authority by Irwin to the agent, nor did he adopt the seal or ratify it by a sealed instrument. Held, that the deed was not Irwin's deed and none of the covenants his covenants, but that if Irwin accepted the grant he became bound if he had signed and sealed the instrument. ${ }^{46}$

\section{Agents Sealing Leases without Authority Personally Liable.}

26. Agents run risk in signing and sealing deeds without placing the names and seals of their principals; for instance, agents contracted for the benefit of a company, yet they did it under their own individual seals, and hence the agents became individually liable. ${ }^{47}$

43 Taylor's Landlord and Tenant, \& r 39

44 Duncan $v$. Hartman, 143 Pa. 595.

45 McDowell $v$. Simpson, 3 Watts, 129.

46 Grove $v$. Hodges, $55 \mathrm{~Pa}$. 504.

47 Quigley v. De Haas, $82 \mathrm{~Pa}$. 267; Kroeger v. Pitcairn, $100 \mathrm{~Pa} .311$. 
Ieases by Agents not under Seal.

27. A written contract not under seal is binding on the principal, in whatever form made or executed, if the principal's name appear in it, and the intention to bind him be apparent. A verbal contract is binding on the principal if his name is disclosed, and the person making it contracts as his agent, and on his behalf. ${ }^{48}$

Parol Evidence Admissible to Prove a Iease not under Seal as Principal's.

28. Parol evidence is admissible to prove that an agreement in writing, not under seal, between $A$. and $B$. was in fact by $\mathrm{A}$. as agent of $\mathrm{C}$., and for his benefit. ${ }^{49}$

Agents making Leases in their own Names Deprive their Principals of their Rights as Landlords.

29. Agents made a lease in their own names throughout the lease, but added the word "agents" to their signatures to the lease. The principal distrained for rent, and he was held liable for a trespass, because he was not to be treated as landlord. The lease does not appear to have been sealed..$^{30}$

When Agent makes a Lease without Disclosing his Principal, Tenant Cannot Deny that the Agent is not Landlord.

30. "Andrew M. Martin, agent," by written lease rented to $\mathrm{H}$. an office and in proceedings of the agent, the tenant wanted to prove that Martin was agent, but that his authority had been revoked. He was not permitted to do so and to deny his landlord's title. It was held, that it was Martin who let the premises. The relation of landlord and tenant by the terms of the lease was exclusively between them. Martin simply describing himself as agent, without disclosing principals, did not place him in the position as agent. ${ }^{51}$

48 I Am. Leading Cases, 6rз.

49 Gilpin v. Howell, 5 Pa. 4I; Bank v. Smith, 3 Brewster R. 9.

50 Seyfert $v$. Bean, 83 Pa. $450 . \quad 51$ Holt $v$. Martin, 5I Pa. 499. 
Agent without Authority in Writing may make Lease not over Three Years.

31. An agent need not be constituted by writing to make leases not under seal for a term not over three years. ${ }^{52}$

Personal Liability of Agents for their Contracts when they do not Disclose their Principals.

32. An agent who contracts on behalf of an undisclosed principal, is personally bound. ${ }^{53}$ A lease was signed by the agent of the owners, merely as agent, but reciting the names of the owners as principals, and purporting to be a grant not in his own right, but as agent. The informal execution would not leave the grantee in possession as a trespasser. It is not at all analogous to Basset $v$. Hawke, ${ }^{54}$ and similar cases where the instrument purported to grant the attorney's own estate only without connecting his principal at all..$^{55}$ A lessee, in the face of the terms of a written lease and an assignment thereof, cannot relieve himself of personal liability by showing by parol evidence that he was acting as agent of a proposed corporation without showing that the execution of the lease was induced by fraud, misrepresentation, etc. ${ }^{56}$

\section{LEASES BY AND TO PARTNERS.}

Leases by Partners should be Sealed by All the Partners.

33. One partner cannot bind his co-partner by a deed, though given in a transaction in the course of the business of the firm and the benefit be received by the firm; ${ }^{57}$ he cannot, without authority of his co-partner, give a sealed lease of the partnership property. ${ }^{58}$ A partner may bind his copartner by contract under seal if the latter previously assent or subsequently ratify it, and this may be shown by parol. ${ }^{53}$

52 Miles v. Cook, I Grant, 58. 53 Beymer v. Bonsall, 2 W. N. C. 229.

54 Basset $v$. Hawke, I 4 Pa. 502.

55 Duncan v. Hartman, $143 \mathrm{~Pa} .595$.

56 Sanders $v$. Sharp, I 53 Pa. 555. 57 Hart $v$, Withers, I P. \& W. 285.

58 Snyder v. May, I9 Pa. 235; Whitaker v. Richards, I34 Pa. I9I.

59 Bond $v$. Aitkin, 6 W. \& S. I65. 
Lease by One Partner of Partnership Property.

34. If a lot is partnership property and used as such, a lease though made by one partner alone would inure to the benefit of the firm, for partners are the agents of each other in partnership transactions, and when real estate is brought into partnership business it is treated in equity as personal estate, and a lease of it by one partner is as much a partnership transaction as a sale of partnership goods by him would be. ${ }^{60}$

Partners taking Leases in their own Names for the Firm, Hold in Trust for the Firm.

35. If a partner takes a lease of lands in his own name for the purposes of the partnership, he will be considered in equity as a trustee of such lease for himself and co-partner. ${ }^{61}$

If one partner obtains in his own name, either during the partnership or before its assets have been sold, a renewal of a lease of the partnership property, he will not be allowed to treat this renewed lease as his own, and as one in which his co-partners have no interest. ${ }^{62}$

\section{LEASES BY MINORS AND GUARDIANS.}

\section{Minors' Leases.}

36. If a minor leases lands, the lease is not void, it is only voidable. It may be avoided by the minor when he comes of age, or by his heir if he die in his minority. ${ }^{63}$ Where an infant lessee, after reaching full age, holds over, he becomes liable for past and future rent under a lease made during minority. ${ }^{64}$

Leases by Guardians.

37. A guardian of the estate may make leases and may sue and distrain for rent. ${ }^{65}$

60 Moderwell $\%$. Mullison, 2r Pa. 257. 6r Collyer on Partnership, I60.

62 Lindley on Partnership, 574. 632 Hilliard on Contracts, r30.

64 Harris $v$. Knowles, 26 W. N. C. 249.

65 Carskadden $v$. M'Ghee, 7 W. \& S. 140. 


\section{LEASES BY AND TO MARRIED WOMEN.}

Power to Lease under Act of 1893.

38. By the act of assembly of June 8, I893, a married woman has the same right and power as an unmarried person to lease her real estate, and may make any contract in writing or otherwise which may be necessary, appropriate, convenient or advantageous to the exercise or enjoyment of her right and power to lease.

\section{Ieases to Married Women.}

39. A married woman can become lessee. ${ }^{66}$

\section{LEASES BY TENANTS FOR LIFE.}

Lease must Terminate at Death.

40. A tenant for life cannot make a lease to extend beyond the term of his own life. When the remainderman or reversioner joins with the tenant for life in making a lease, it is good, and is considered during the life of the tenant tor ire as his lease, and the confirmation of the remainderman or reversioner; and after the death of the tenant for life it is taken to be the lease of the remainderman or reversioner. ${ }^{67}$

\section{LEASES BY AND TO CORPORATIONS.}

May make Leases as Natural Persons.

4I. When a corporation is acting within the scope of the legitimate purposes of its institution, all parol contracts made by its authorized agents are binding. Within the sphere of its proper functions it may contract pretty much as a natural person may. ${ }^{68}$

Kay Contract without Writing.

42. Corporations may contract otherwise than in writing. ${ }^{69}$

66 Lloyd $v$. Underkofler, 13 Phila. 160. 676 Coke, I41.

68 Hamilton $v$. Insurance Co., $5 \mathrm{~Pa} .339$.

69 I Hilliard on Contracts, 558. 
Leases to Foreign Corporations.

43. A foreign corporation may lawfully take a lease of an office in this state in which to transact business. Though no corporation can hold real estate beyond the authority conferred in its charter, the principle does not extend to a lease. A foreigner may lease a house to shelter himself and family, although he be prohibited from holding real estate. ${ }^{70}$

\section{Offcers must be Authorized to Lease.}

44. A lease made by certain officers of a corporation unauthorized so to do, will be declared invalid. Mere silence will not be construed into acquiescence. ${ }^{71}$ In case of a lease of importance it would be well to see that the directors in a regular way authorized the lease.

Corporation Cannot Disable Itself from Performing Public Duties by a Lease.

45. Railroad company cannot lease its rolling stock, etc., without the consent of the state. ${ }^{72}$

Corporate Seal Not Necessary to Hold a Corporation in Assumpsit.

46. Assumpsit lies for rent upon a lease by a corporation, executed without its seal. ${ }^{73}$

\section{Corporation may Ratify Agents' Acts.}

47. The acceptance by a corporation, of the contract of its officer, and action under it, is a ratification of the authority of the officer in making the contract. ${ }^{74}$

70 Steamboat Co. v. McCutchen, I3 Pa. 13.

7 I Oil Co. v. Railroad, 12 Phila. 374.

72 Thomas $v$. Railroad, 9 W. N. C. 65.

73 Morrison v. Beirer, 2 W. \& S. 8r.

74 Goldbeck $v$. Bank, $147 \mathrm{~Pa}, 267$. 


\section{LEASES BY TENANTS IN COMMON.}

May make Joint or Separate Leases.

48. Tenants in common may make separate leases for their respective interests for separate rents, or they may all join in one lease, with one render of the entire rent to the lessors simply, in which case they may sue jointly. ${ }^{75}$

When a Joint Lease is made by Tenants in Common they must Sue Jointly.

49. Land belonging to eleven heirs of a decedent was leased by seven of them. The agreement was not to pay to each lessee his individual part, but to them all a gross sum, and it was held that, the lease being by the lessors jointly, one could not recover a fractional part of the rent. ${ }^{76}$

Iiability of Tenant in Common to Pay his Co-Tenants not in Possession.

50. It was held that, in the absence of an express contract, cne tenant in common could not recover from another for the use and occupancy of the common land, either at law or in equity. ${ }^{77}$ To remedy the unjust effects of this law, the act of June 24, I895, was passed, whereby tenants in common, not in possession, can recover from their co-tenants in possession, their proportionate parts of the rental value of the real estate, and in cases of partition the parties in possession are liable to have deducted from their distributive shares the rental value to which their co-tenants are entitled.

\section{LEASES BY TRUSTEES AND EXECUTORS.}

Powers of Trustees Limited by the Trusts.

5I. Trustees of lands, being the owners of the legal estate, may grant leases which cannot be impeached, so long as they are justified by the quantity of the estate they possess. ${ }^{78}$

75 Taylor's Landlord and Tenant, §§ I15, II6.

76 Marys $v$. Anderson, $24 \mathrm{~Pa} .272$.

77 Norris $v$. Gould, I5 W. N. C. 187.

78 Taylor's Landlord and Tenant, § I 30. 
Administrator Cannot Lease.

52. An administrator has nothing to do with real estate, or the renting of the real estate, or the collection of rents.

Until Real Estate is Sold to Pay Debts the Rents go to Heirs or Devisees.

53. Until a sale of real estate of an intestate for the payment of debts, it belongs to the heirs or devisees, who are entitled to the rents although the estate may be insolvent. ${ }^{i 3}$

An Executor, unless he is made a Trustee of Real Estate, Cannot Lease the Same.

54. An executor of a will is in the same position as an administrator as to real estate, unless in some way he is made a testamentary trustee of the real estate, and the parties taking leases from executors would often do well to take the advice of counsel as to the authority of the executors to lease, and when the lease is one of importance, and there are doubts as to the time for which the lease should run, it would be well to get the direction and approval of the proper court.

\section{In Case Executors have a Mere Power to Sell Real Estate.}

55. It often occurs that a will devises real estate directly to devisees with a power given to executors to sell real estate. In such case, until the power is exercised, the real estate belongs to the devisees, who have control of the renting and of the collecting of the rents thereof. ${ }^{80}$

In Case of a Trust to Sell, but Not to Rent.

56. A trustee will not be chargeable for not renting real estate, which is unproductive and uninclosed, when the object of the trust is a sale and not renting.

Power of Trustees to Agree to a Renewal of Lease.

57. An estate was vested in a trustee to lease, and apply the rents during certain lives. The trustee leased for five

79 Adams v. Adams, 4 W. 160.

8o Blight $v$. Wright, I Phila. 54z. 
years with the option of renewal, and it was held that the lease was not void because subject to renewal. If the power was. abused it might have given rise to a remedy against the trustee in damages, or if by collusion against both trustee and lessees. ${ }^{81}$

\section{Case of Personal Liability of an Executrix under a Iease.}

58. A lease was made to a woman as executrix of the estateof her deceased husband, and it was held, that she was personally bound, upon the principle, that a promise made by an executor does not bind the estate, but the executor personally, and in such case the naming of a party as executor ismere surplusage. ${ }^{82}$

\section{Assignee for the Benefit of Creditors Cannot Lease.}

59. In case of an assignment for the benefit of creditors by deed of the usual form, the only duty of the assignee is to sell the real estate under the power of sale in the deed, or under order of court, and until such sale the assignor may occupy the premises or receive the rents thereof for his own. use. The object of the assignment is to convert the property by sale, and not for the assignee to work the land or let it to. others. His position is similar to that of an executor with a naked power of sale. ${ }^{83}$

\section{DESCRIPTION OF PROPERTY RENTED.}

Not Necessary to Particularly Describe Premises in a Lease.

6o. It is not necessary nor usual to describe the premises demised with the same particularity as in a conveyance. If the property is described in the lease, in a general way, it is. sufficient, but to provide for an action of ejectment under the lease, the property had better be fully described or a street number, if any, given to comply with the law as to ejectments. 
Ambiguous Description Supplied by Evidence Outside of the Lease.

6r. Questions often arise as to what is demised which have to be solved by parol or other evidence outside of the lease. It may always be shown by parol evidence what was and what was not parcel of the demise, and intended to pass to the lessee. By evidence of extrinsic circumstances a general and comprehensive term may be controlled and restricted, to pass much less than is usually included in the common legal meaning of the term, and, on the other hand, a particular and limited term and description may be extended to comprehend and include much more than it generally comprises, in order to give effect to the plain and obvious meaning of the parties. ${ }^{84}$ It was held that it was competent to explain by parol evidence what land was demised, and that a part of a tract of land demised was not included in the lease. ${ }^{85}$

List of Furniture should be Annexed to Lease.

62. If a furnished house be leased it is important to have a list of the articles attached to the lease, to be retained by the landlord, and power can be given in the lease for the landlord to take the furniture in case of trouble. The tenant is bound to preserve the furniture in good order. ${ }^{86}$

Intention of What is Leased, from Actual Use.

63. So, where the agreement was that "the present lessee and occupant of the first floor," etc., might "continue to use" the same, it being conceded that he did not have a literally exclusive possession of the whole first floor, parol evidence was admitted to show what he actually used and occupied before the agreement was executed.

Case of Property Described as on the Wrong Corner.

64. It is no defence that the premises are described in the lease as on the wrong corner. ${ }^{87}$

84 Addison on Contracts, vol. 2, §68r.

85 Tate $v$. Reynolds, 8 W. \& S. 9r.

862 Bouvier's Dic. (Rawle), 45. 87 Henry v. Wilson, I W. N. C. 506. 
Exceptions and Reservations in Lease.

65. When the whole of a property is not intended to be leased, and a part is to be retained by the landlord, a general description of the whole premises may be qualified by an exception; for example, a field can be excepted out of a farm, or a room out of a house, and if the lessor intends to retain a right of way or any other right or control over the demised premises, he must expressly reserve it.

Implied Grant of Things Necessary for the Use of Property.

66. A grant of the thing passes the incident as well as the principal, though the latter only be mentioned; thus a mansion would include all the outbuildings used with the same. Generally all those things necessary to the enjoyment of the thing granted will pass without being described. ${ }^{88}$

\section{Authority of Landlord to Enter After He has Leased.}

67. The landlord can reserve the right to go upon the premises peaceably, for the purpose of ascertaining whether any waste or injury has been committed by the tenant or other persons, first giving notice of his intention. But he has no such right unless he reserves it in the lease. He may also ise all ways appurtenant thereto, and peaceably enter the premises to demand rent, to view waste, or to remove an obstruction..$^{89}$ But if the rent is payable in hay or produce, to be delivered to him, he is not entitled to go upon the land and take it, until it is delivered to him by the tenant, or until aiter it has been severed and set apart for his use.

\section{Estate for Years.}

\section{TERM OF A LEASE.}

68. An estate for years is for some determinate period. If the lease be for but one-half a year, or a quarter, or a less time, the lessee is a tenant for years. ${ }^{90}$

88 Taylor's Landlord and Tenant, $\$$ 157, 158, 161, 162.

89 Story on Contracts, $\S 900 . \quad 902$ Blackstone's Commentaries, 140. 
Estate at Will.

69. An estate at will is where lands are let to hold at the will of the lessor. ${ }^{91}$

Tenant from Year to Year.

70. A tenancy from year to year is where lands are expressly or impliedly demised by the landlord to the tenant to hold from year to year, so long as the parties respectively please. ${ }^{92}$

Tenancy from Quarter to Quarter, from Month to Month, etc.

$7 \mathrm{I}$. When the tenancy is for a short period, as for a quarter, a month or a week, and the tenant holds over, there is established like in the case of a tenancy from year to year, a tenancy from quarter to quarter, and from month to month, and from week to week. ${ }^{93}$

\section{Perpetual Leases.}

72. The term of a lease may be perpetual. ${ }^{93 *}$

\section{Lease Without a Term Stated.}

73. Where there is a demise for an annual rent, and no term is mentioned, there is a lease from year to year. ${ }^{94}$

Tenancy from Year to Year by Express Agreement.

74. Where a lease is made from year to year conditioned to be null and void if rent is not paid at a stated time it is not for a fixed and determinate period, but a lease from year to year.

Term of Tenancy Implied by the Payment of Rent.

75. Where rent is received by a landlord, that raises an

9I Blackstone's Commentaries, I45.

922 Addison on Contracts, $\$ 684$.

93 Taylor's Landlord and Tenant, $\S 478$.

93* Effinger $v$. Lewis, $32 \mathrm{~Pa}$. 367.

94 Hey $v$. McGrath, 8ז $3 \frac{2}{2}$ Pa. 310. 
implied tenancy from year to year, or the like, though the tenant was originally let in under an invalid lease.

Landlord may Elect to Treat Tenant Holding Over after Lease as Tenant or Trespasser.

76. Where the lease is for a definite period and the tenant holds over, the landlord may treat him as a tenant by sufferance, and turn him out without three months' notice previous to the end of the period, but the landlord may at his election treat the tenant from year to year at the same rent. ${ }^{95}$

Tenant by the Month may Terminate Lease at End of Any Month.

77. If a tenant rents by the month he has the right to terminate the lease at the end of any month. ${ }^{96}$ When we are dealing with the question of an implied renewal of a tenancy, all the terms of the former lease must be considered. The purpose is not to make a new lease essentially different, but to continue the former as far as its terms may be applicable. In its very nature the implied renewal of a lease assumes a continuation of its characteristic features. Hence if a landlord elect to treat one holding over as a tenant, he thereby affirms the form of the tenancy under which the tenant previously held. If there was a tenancy by the month, it will presumably so continue. The landlord cannot impose a longer term or one radically different from the former. ${ }^{97}$

A Lease from Year to Year, at the Pleasure of the Parties, a Continuous Lease.

78. A lease from year to year during the pleasure of the parties, is only a lease for one year certain, and every year after it is a springing interest arising from the first contract and parcel of it; so that with a view to the time which has elapsed or the number of years which the tenant has occupied, it is considered an estate for all that time, including the cur-

95 Hemphill $v$. Flynn, 2 Barr, I44.

96 Milling $v$. Becker, $96 \mathrm{~Pa}$. 182.

97 Hollis v. Burns, $100 \mathrm{~Pa} .206$. 
rent year, and the lessor may distrain and avow as for so much rent in arrears upon one entire lease. After the commencement of each new year it becomes an entire lease certain for years past and also for the year entered upon. ${ }^{98}$

The Beginning and End of a Lease.

79. A lease of land for one year from the first day of April, expires on the last day of March of the next year. The first day of April when the lease was to commence, being included in the term. ${ }^{99}$

\section{Continuation of Lease at Option of Tenant.}

8o. If the duration of a lease is left optional by the terms of the lease, it must be construed favorably to the tenant. If the duration is left optional by the terms of the lease, without saying at whose option, as, for instance, if a lease is made for seven, fourteen or twenty-one years, it means at the option of the tenant, who has the right of choosing whether he will put an end to the lease at the end of seven years, or continue it for fourteen years or twenty-one years. ${ }^{1}$.

\section{Agreements for Extension of Terms and Options.}

$8 \mathrm{I}$. It is customary to have the lease to continue from time to time in default of notice and to give options of renewals. As to these matters the practical directions for renting property are referred to.

In What Payable.

RENT.

82. Rent may be payable in money, provisions, chattels or labor.

What Rent may Issue Out of.

83. A rent may issue out of lands and tenements corporeal and their furniture. ${ }^{2}$

98 Roberts' Dig. 317. 99 Marys $v$. Anderson, $24 \mathrm{~Pa} .272$.

I Com. v. McNeile, 8 Phila. 438. 2 Mickle $v$. Miles, 3I Pa. 20. 
Interest on Rent.

84. Interest can be claimed on rent at the time it is due; although it cannot be included in a claim for a distress. ${ }^{3}$ Rent carries interest from the time it is due, unless from the conduct of the landlord it may be inferred that he means not to insist on it, or unless he acts in an oppressive manner by demanding more than is due where the tenant is willing to do justice, or there are other equitable circumstances making the charge improper. ${ }^{4}$

When no Time Fixed for the Payment of Rent.

85. In a lease for a year, if no time is fixed for the payment of rent, whether in money or kind, it is not payable until the end of the year. ${ }^{5}$

\section{Rent Due After a Sale.}

86. In case the landlord sells the demised premises, the rent which falls due after the sale goes to the purchaser, unless there is an agreement to the contrary. ${ }^{6}$

\section{Custom in Philadelphia to Apportion Rent.}

87. In Philadelphia it is the custom to apportion the rent to the date of the settlement of the purchase.

\section{A Tenant Bound by His Covenant to Pay Rent, although He Assigns Lease.}

88. A tenant is bound by his express covenant to pay rent, though he has assigned the lease with thelandlord's assent and the assignee is accepted as tenant, and although the rent has been received from him, unless the landlord has accepted the surrender of the former and released him. ${ }^{7}$

3 Gaskins थ. Gaskins, I7 S. '\& R. 390.

4 Obermyer $v$. Nichols, 6 Binn. I58; Railroad Co. $v$. Smith, 105 Pa. I95.

5 Boyd v. McCombs, 4 Barr, 146.

6 Johnson $v$. Smith, 3 P. \& W. 496.

7 Frank $v$. Maguire, $42 \mathrm{~Pa} .77$. 
Rent Due Landlord Before He Dies Goes to His Executor as Personal Property.

89. When the lessor, being tenant in fee, dies after the rent becomes due, it will be payable to the executors.

Rent Due After Death of Lessor Goes to His Heir or Devisee.

90. If he dies before it becomes due it will be payable to heir or devisee. ${ }^{8}$

An Agreement of Tenant to Pay Assessments.

91. A clause in a lease which provides that the lessee shall pay all water rents, taxes and assessments upon the premises includes a charge for paving and curbing streets in front of the leased premises, when ordered by the municipal authorities. $^{9}$

Notice to Lessor on Contingency Releasing Lessee.

92. Where a lease provides that on the occurrence of a contingency the lessee shall be relieved of any obligation of the lease, the lessee must give notice to the lessor of the occurrence of the contingency if he desires to avail himself of the benefit thereof; the mere occurence will not work relief. ${ }^{10}$

A Landiord Leaving a Number of Children, Each Child is Entitled to His or Her Share.

93. If the landlord should die leaving a number of children, his estate will descend to them as tenants in common, and the tenant will be bound to pay each child his proper proportion of the rent. ${ }^{11}$

Apportionment of Rent in Case of Sale of Reversion by Landlord in Parts.

94. In case of the sale of a reversion in parts, so that different persons become entitled to the rent, the different

8 Comyn on Landlord and Tenant, 226.

9 Griffin $v$. Pottery Co., I4 W. N. C. 266.

so Double v. Heat Co., 37 W. N. C. 389.

II Bank $v$. Wise, 3 Watts, 394. 
parties entitled to the rent may agree as to an apportionment. If they do not agree the apportionment is to be made by the jury according to the value of the parts. ${ }^{12}$

\section{Rent Payable in Advance upon Contingency.}

95. Rent, even for the whole term, may be made payable in advance and distrained for, upon the happening of any contingency, such as an attempt to remove goods from demised premises. ${ }^{13}$

\section{Tenant Bound by His Covenant to Pay Rent though Property is Burned.}

96. A covenant to pay rent is not extinguished by the destruction of the leased premises by fire, unless there be an express covenant to that effect, and it is no defence to a claim for rent that the premises had been destroyed by fire, and that the landlord had received the insurance money. ${ }^{14}$

Instances of Losses to Tenants for the Want of an Exemption from the Payment of Rent in Case of Fire.

97. There are cases in Pennsylvania showing that the landlords have, in numerous instances, stood upon their legal rights in such cases. In one case it was held that, although the demised property was insured, and the landlord received the insurance money for a loss from a relief fund, there was no defence to the payment of rent in case of loss by fire. ${ }^{15}$

Rerts made Payable to Tenant for Life Apportioned under Act of 1834 .

98. By the act of assembly of Feb. 24, I 834, the rent is to be apportioned to the time of the death, the administrator. of the life-tenant being entitled to the rent, to the time of the death of the life-tenant and the balance going to the remainderman.

12 Reed $v$. Ward, $22 \mathrm{~Pa}$. 144. 13 Goodwin $v$. Sharkey, $80 \mathrm{~Pa}$. I49.

I4 Hazlett $v$. Powell, $30 \mathrm{~Pa} .293$.

I5 Magaw $v$. Lambert, $3 \mathrm{~Pa}$. 444. 
Rent Payable in Grain, etc., Apportioned under Act of 1834.

99. A farm was leased for one year for a portion of the grain. The landlord died during the term. It was held, that the grain was to be apportioned according to said law, in the same proportion that the time from the beginning of the lease to the death of the landlord bore to the whole year; the current period being the whole of the year for which the lease was drawn. ${ }^{\mathbf{1 6}}$

When Rent is Payable in Grain, it is Not Due until Delivered.

I00. When the landlord is entitled to a share of grain in the ground, deliverable in the bushel, until the grain is severed and delivered to the landlord, he has no interest in the thing itself. If he sells, it goes to his vendee, and the landlord cannot pursue it in his hands. The only remedy for the landlord is by distress as in case of money rent. ${ }^{17}$ Grain severed before sheriff's sale will not pass to the purchaser. ${ }^{18}$

Interest of Landlord in Share of Grain Cannot be Taken in Execution Before Severance,

IOI. Where land is let to a tenant on shares, the interest of the landlord in the growing grain cannot be seized and sold on execution before severance, so far as to pass a title thereto against a purchaser at sheriff's sale of the land. ${ }^{19}$

\section{Good-will of Demised Premises.}

102. The good-will is not to be considerd separately from the rental, and its value is to be considered in fixing the rent. If a tenant establishes a good-will, the landlord will receive the benefit thereof upon the expiration of the tenant's lease, and the good-will will be inseparably attached to the premises. Of course, a landlord could agree to pay for the good-will at

16 Borie v. Crissman, $82 \mathrm{~Pa}$. 125.

17 Rinehart $v$. Olwine, 5 W. \& S. 157.

18 Long v. Seavers, I03 Pa. 5I7; Baker v. Lewis, I50 Pa. 25 I.

19 Long $v$. Seavers, Leg. Int. (Sept. 21, I883), Vol. 40, p. 359. 
the end of the lease, but he would not be likely to do so, and if a tenant expects to create and keep a good-will, he can have the lease to provide for a long term, with no provision for the landlord to terminate the lease except for defaults of the tenant. ${ }^{20}$

\section{COVENANTS.}

\section{Covenants Running with the Land.}

I03. A covenant is said to run with the land when either the liability to perform it or the right to take advantage of it passes to the assignee of the land. ${ }^{21}$

\section{Implied Covenants Run with the Iand.}

I04. All implied covenants run with the land; ${ }^{22}$ some express covenants in leases run with the land and others do not.

\section{When Covenants Run with the Land.}

I05. A covenant runs with the land when it relates to or touches and concerns the land in such a way that their benefit or burden is capable of running with it. ${ }^{23}$

\section{Assignees Bound by Covenants Running with the Land.}

Io6. In a covenant running with the land the assignee is bound without naming him. ${ }^{24}$

\section{Examples of Covenants Running with the Land.}

I07. The following are some of the covenants which run with the land, viz.: For quiet enjoyment; further assurance; to repair; to give peaceable possession to the lessor; to give the lessor right of way; to cultivate lands in a particular manner; to carry on a particular trade; to supply a lessee with water; to pull down old chimneys and erect new ones; for punctual payment of rent; to insure a factory with machinery and fixtures. 
Covenant to Pay Rent.

IOS. In every lease a covenant for the payment of rent should be inserted. If there is no such covenant, an agreement to pay as much as the property is worth will be implied. One of the advantages of an express covenant is, that, upon such covenant, the tenant always remains liable to pay the rent. In case there is only an implied agreement, the tenant can rid himself of all future liability by assigning the lease even to a beggar. ${ }^{20}$

\section{Covenants Not to Assign or Underlet.}

I09. A condition in a lease that the lessee or his assigns shall not alien, without the special license of the lessor, is determined by an alienation by license; and no subsequent alienation is a breach of the condition, nor does it give a right of entry to the lessor. ${ }^{26}$

\section{Are Construed Strictly.}

I IO. A condition against the assignment of a lease will not embrace an underletting, nor will a proviso that the demised premises shall not be underlet preclude the power of making an assignment. ${ }^{27}$

\section{An Assignment by Law Not a Breach.}

III. An assignment by act of law, as in bankruptcy, or by execution, is not a breach of the covenant not to assign, and even a sale of a lease under an execution upon a confession of judgment given bona fide by the tenant will not be a breach. ${ }^{27 *}$ To avoid such a result, leases sometimes have a provision against involuntary assignments; for example, "nor shall the lessee assign the term hereby granted, or underlet the premises, without the written consent of the lessor en-

25 Taylor's Landlord and Tenant, § $37 \mathrm{I}$.

26 Dumpor's Case, I Smith's Leading Cases, 89.

27 I Smith's Leading Cases, 128.

$27^{*} 2$ Stephens' Nisi prius, II 24. 
dorsed thereon, an assignment within the meaning of this lease being understood and intended to comprehend not only the voluntary action of the lessee, but also every levy or sale on execution, or other legal process, and every assignment or sale in bankruptcy or insolvency, or under any other compulsory procedure or order of court." It has been held, that a receiver of a lease cannot transfer it without the assent of the lessor, the lease prohibiting an assignment without such consent. ${ }^{28}$

\section{Covenant as to Use and Occupancy.}

II2. There can be such a covenant and by agreement its violation may cause a forfeiture of the lease.

\section{Iandlord Not Bound to Repair.}

II3. In the absence of an express agreement, there is no implied agreement of the landlord to repair demised premises, nor does he impliedly undertake that they are fit for the purposes for which they are rented; that they are tenantable, or shall continue so. If they burn down, he is not bound to rebuild. The rule here, as in other cases, is caveat emptor (let the purchaser beware). The lessee's eyes are his bargain. $\mathrm{He}$ is bound to examine the premises he rents, and secure himself by covenants to repair and rebuild. ${ }^{29}$

\section{The Repairs a Tenant is Bound to Make.}

II4. A lessee for years is bound to make tenantable repairs, such as putting in windows or doors that had been broken by him, or repairing fences and highways, and keeping the premises wind and water-tight, so as to prevent obvious waste and decay; but is not bound to make lasting and general repairs, such as putting a new roof upon an old, worn-out house or building, or putting up new fences. The extent to which he is bound to repair is not very definitely limited; 
but he seems not to be bound to make good such deteriorations as arise from necessary wear and tear incidental to a proper use, or for injuries resulting from inevitable accident, unless they can be remedied at slight expense and would otherwise occasion serious damage; but whatever injuries are occasioned by his voluntary negligence he is bound to repair; but a tenant is not bound to supply or maintain anything in the nature of ornament, such as painting, whitewashing, or papering, unless it be necessary in order to preserve exposed timber from decay. And the rule prevails, though the tenant be under a covenant to leave the premises "in good and sufficient repair, order and condition." $29 *$

\section{Express Covenant of Tenant to Repair.}

I I5. Where in a lease there is an express and unconditional agreement to repair and keep in repair, the tenant is bound to do so, though the premises be destroyed by fire or other accident. To guard against such a result there can be an exception in the contract or the tenant can insure against the risk. ${ }^{30}$

Tenant is Not Bound by His Covenant to Repair Injuries by Act of God or Public Enemies.

I I6. The tenant is not, by his covenant to repair, bound to repair an injury occasioned by an act of God or a public enemy. ${ }^{31}$

Tenant Cannot Charge Landlord for Permanent Repairs made Without His Authority.

I I7. If a tenant put permanent repairs on the premises without consent of the landlord, he cannot charge the landlord for them. ${ }^{32}$

29* Story on Contracts, $\S \S 924,925$.

30 Hoy $v$. Holt, 9I $\mathrm{Pa} .88$.

31 Pollard $v$. Shaaffer, I Dallas, 2ro.

32 Kline v. Jacobs, $68 \mathrm{~Pa} .57$. 
Agreement of Landlord to Repair Minor to that of Tenant to Pay Rent.

I I8. A tenant in possession agreed to take a lease of premises for another year if the landlord would make certain repairs and additions, which he agreed to do. The tenant refused to pay the rent because the landlord had not repaired and made the additions. The landlord distrained for rent, and in an action of replevin it was held that if the tenant held and enjoyed the demised premises, the covenant on the part of the landlord to repair and make additions was minor and subordinate, and did not go to the essence of the contract, so as to defeat the rent in toto; that he was not discharged from liability to pay the rent unless the building was worthless for the purpose for which it was rented without such additions and improvements, and if any damages had occurred to the tenant by reason of such non-performance on the part of the landlord, the tenant is entitled to have them deducted from the rent due, and if in excess, to a verdict. ${ }^{33}$

\section{Measure of Damages when Landlord Breaks His Agreement to Re- pair.}

I I9. A lease of a hotel stipulated that the landlord would raise the house, add a new story, and make other alterations; the tenant alleged that the alterations had been negligently done, and that his furniture had been injured, etc., he refused to pay the rent, on the ground that he suffered greater damage than its amount. The landlord distrained. In replevin held, the measure of damages to be the difference between the amount for which the property would have rented with the improvements, and the amount for which it would rent without them. ${ }^{34}$

\section{Tenant Not Relieved from Loss in Business during Repairs.}

120. Where a landlord enters by consent of the tenant to make repairs, with a stated reduction of rent for the time re- 
quired, the tenant cannot set up as a defence, the damage to his business resulting from the unexpected length of time in making the repairs unless unreasonably delayed. ${ }^{35}$

The Covenant that Improvements shall Remain Should be Guarded Against by the Tenant as Dangerous.

I21. An expensive boiler was put in a brewery by a tenant and it was held, that under such a covenant it could not be removed. ${ }^{36}$ This is a dangerous covenant to a tenant who may put up fixtures. If all fixtures are not included in the term improvement, it will often be difficult to draw a dividing line between those fixtures which may be classed as improvements and those which are not.

\section{Definition of the Word, "Improvement."}

I22. The Supreme Court seems to think that an engine would not be comprehended as an improvement, but that it would apply to permanent fixtures or buildings, etc. ${ }^{37}$

\section{Covenant of Landlord to Sell to Tenant.}

I23. Where the lease, or a writing signed by the lessor, gives a tenant the right to purchase the demised premises, equity will enforce specific performance. ${ }^{38}$

\section{Covenant for Re-Entry.}

I24. Leases sometimes contain a proviso or covenant for a re-entry by the landlord in case the tenant does not pay the rent or perform his agreements; for example the following form is given: "Provided always, and it is hereby expressly agreed, that if the rent hereby reserved, or any part thereof, shall be unpaid for days after any of the days on which the same ought to have been paid (although no formal demand shall have been made thereof), or in case of the breach

35 Reinman v. Blair, $96 \mathrm{~Pa} .155$.

36 Agnew $v$. Whitney, to Phila. 77.

37 Lemar $v$. Miles, 4 Watts, 330.

38 Newell's Ap., 39 Leg. Int. 336. 
or non-performance of any of the covenants and agreements herein contained, on the part of the said lessee, his executors, administrators, and assigns, then, and in either of such cases, it shall be lawful for the said lessor, at any time hereafter, into and upon the said demised premises, or any part thereof, in the name of the whole, to re-enter, and the same to have again, repossess and enjoy, as of his or their former estate, anything to the contrary notwithstanding."

\section{Requisites Before Entry.}

125. At common law, before a landlord could enter for a forfeiture for non-payment of rent, he must have made a formal demand of the precise sum due for the last current quarter only on the date it became due, before sunset, at the most notorious place upon the demised premises, or at the place mentioned for payment in the lease. ${ }^{39}$ In the above form a formal demand of rent is dispensed with, which dispensation will be operative.

\section{There Must Not be a Breach of the Peace in Making Entry.}

126. Notwithstanding a landlord may have the right to take possession of the demised premises, by a forfeiture or a termination of the lease, he cannot commit a breach of the peace in so doing, as will appear under the section as to forcible entry and detainer.

\section{In Pennsylvania a Re-Entry is Not Necessary for a Forfeiture.}

127. In England re-entry is necessary to express the option of the landlord to claim a forfeiture, whilst in Pennsylvania it depends upon the terms of the instrument, unless there be evidence to affect the landlord with a waiver of the breach, like the receipt of rent, or other equally unequivocal act. $^{40}$ Leases for years, granted on condition to be null and

39 Taylor's I.andlord and Tenant, § 493; McCormic v. Connell, 6 S. \& R. 150; Roberts $v$. Ristine, 2 Phila. 62.

40 Sheaffer $v$. Sheaffer, $37 \mathrm{~Pa} .525$; Davis $v$. Moss, $38 \mathrm{~Pa}$. 346. 
void, become so by breach of the condition, and cannot be set up by recognition. ${ }^{41}$

\section{Waiver of Forfeiture.}

I28. If the condition is, that the landlord may re-enter or avoid the lease, the lease is voidable only and may be affirmed by the acceptance of rent, if the lessor has notice of the breach at the time. ${ }^{42}$

\section{Amicable Action and Confession of Judgment in Ejectment.}

I29. Leases may contain an agreement that if the tenant does not pay his rent, deliver possession or perform any of his agreements, an amicable action and confession of judgment in ejectment may be entered of record in court, and that the landlord may thereupon be put into possession by the sheriff. One of the forms for such purpose is as follows: "And it is further agreed, that if the said rent shall at any time be in arrear or unpaid, or if the said lessee shall underlet or otherwise use the said premises than as above expressed, or shall fail to comply with the conditions of this lease, or notice given under the terms hereof, or shall not well and truly perform and fulfill all and every the covenants and agreements herein contained on the part of the lessee to be performed and kept, then this lease shall, at the option of the said lessor, cease and absolutely determine, and any attorney may immediately thereafter, as attorney for the said lessee, at the sole request of the said lessor, sign an agreement for entering in any competent court, an amicable action and judgment in ejectment (without any stay of execution or appeal) against the said lessee, and all persons claiming under said lessee, for the recovery by the said lessor of possession of the hereby demised premises, without any liability on the part of the said attorney, for which this shall be a sufficient warrant; and thereupon a writ of habere facias possessionem may issue forthwith without any prior writ or proceeding whatsoever, and 
the lessee hereby releases to the lessor all errors and defects whatsoever in entering such action or judgment, or causing such writ of habere facias possessionem to be issued, or in any proceeding thereon, or concerning the same; and hereby agrees that no writ of error or objection or exception shall be made or taken thereto; and a copy of this lease, verified by affidavit, being filed in said action, it shall not be necessary to file the original as a warrant of attorney, any law or rule of court to the contrary notwithstanding. No such determination of this lease, nor taking or recovering possession of the premises, shall deprive the lessor of any other action against the lessee for possession, for rent or for damages. All rights and liabilities herein given to, or imposed upon either of the parties hereto, shall extend to the heirs, executors, administrators, successors and assigns of such party." In case the landlord desires to recover possession upon such a provision, he employs an attorney-at-law, who will prepare the necessary papers and have judgment entered and a writ for possession handed to the sheriff. If the tenant has any defences or legalobjections to the proceeding, he also employs an attorney who will have the judgment opened and the tenant let into a defence.

\section{If Tenant has not Paid His Rent Punctually He Must be Warned Before Entry of the Judgment for Non-Payment.}

I30. In a lease the rent was to be paid monthly on certain days. After the first payment the rent was never paid punctually, but was received when tendered, and it was held that the conduct of the lessor in receiving the rent at any time was sufficient to induce the lessee to believe that the right to reçover possession by means of an amicable judgment in ejectment could not be insisted upon. If notice had been given that future payments must be made on the day when due, the case would have been different. ${ }^{43}$

43 Cogley $v$. Brown, II W. N. C. 224; Oliver $v$. Brophy, i8 W. N. C. 427. 
For a Purchaser to Have Benefit, the Lease should be Assigned.

I 3 . The warrant of attorney in the lease for confession of judgment for possession does not run with the reversion. The power cannot be exercised by any one who has not a specific assignment of the lease. ${ }^{44}$

\section{No Appeal to Supreme Court Allowed.}

132. A judgment confessed in an amicable action of ejectment under a lease, is not within the act of April 4, I879, providing for appeals in case of applications for the opening of judgments entered under warrant of attorney. ${ }^{45}$

\section{Position of Under-Tenants.}

133. A lease contained a provision for entering an amicable action of ejectment. It was signed by the lessee alone. Judgment was entered against the lessee and his subtenant. The under-tenant could be put out upon the judgment against the lessee, but judgment could not be entered against the under-tenant in ejectment. ${ }^{46}$

\section{Possession by Those Holding Paramount Title.}

134. After a judgment had been entered in an amicable action in ejectment by a landlord against his tenant, the sheriff returned to a writ for possession that he found the premises in possession of one not a party to the ejectment, who claimed to hold a paramount title. To the return of the sheriff was annexed an answer by the outside party, setting forth that he was in possession of the premises at the time the action in ejectment was brought, and that the tenant was not in possession; that he did not claim under the tenant but under another party. It was held that as the outside party was brought upon the record by the proceedings on the rule, and as the order directly affected his right to the possession

44 Hockley $v$. McGlinn, 40 Leg. Int. 279.

45 Swartz's Ap., I19 Pa. 208.

46 Stewart v. Lawson, J8 $\mathrm{I}$ Pa. 549. 
of the premises in suit, he was entitled to a writ of error, and that as such party was in possession of the premises and was not made a party in the proceedings, and as he claimed title paramount to the tenant, and not under him at all, the action of the court in ejecting him without hearing or trial was error. ${ }^{47}$

\section{Implied Covenant for Quiet Possession.}

I 35. In every demise there is an implied covenant of peaceable and quiet enjoyment, but not a guarantee to the tenant from injury by the wrongful acts of a stranger. The covenant for quiet enjoyment only means that the tenant shall not be evicted or disturbed by a good title in the premises or part of them. ${ }^{48}$

\section{Implied Covenant to Protect Tenant Against Paramount Claims.}

136. The landlord is bound to protect the tenant from all paramount claims. ${ }^{49}$ Such payments are considered as actual payments of so much rent, and may be pleaded by way of payment as contradistinguished from set-off. In cases of landlord and tenant, the very relation in which the parties stand to each other creates an implied covenant upon the landlord's part, that the tenant shall appropriate such part of his rent as shall be necessary to indemnify him against prior charges, and that the money so appropriated shall be paid on account of rent. The landlord is obliged to pay all arrears of ground rent or interest upon mortgages to which the property leased may be subject. Some cases hold that a mere threat of a distraint, and others hold that a mere demand of rent is sufficient to authorize the tenant to pay it. ${ }^{50}$ A subtenant may pay the paramount landlord where his occupation of the premises is liable to interruption from default in pay-

47 Hessel v. Fritz, 23 W. N. C. 299.

48 Moore $v$. Weber, 71 Pa. 429; Barns $v$. Wilson, 1 16 Pa. 303.

492 Addison on Contracts, 350 .

jo Notes to Lampleigh $v$. Brathwait, I Smith's Leading Cases, 277, 279. 
ment of the paramount rent. He need not wait for process. to be taken against him. ${ }^{51}$

\section{Implied Covenant to Use Property in Tenant-like Manner.}

I37. A tenant must take reasonable care of the property, and restore it at the expiration of the term for which it is hired in the same state and condition as it was when demised, subject only to the deterioration produced by ordinary wear and tear and the reasonable use of it for the purpose for which it was hired. ${ }^{52}$

\section{Covenants as to Farming.}

I 38 . It is implied from the letting of a farm for agricultural purposes that the tenant will cultivate and use the land according to the rules of good husbandry. ${ }^{53}$ Where a contract of a decedent is personal and his performance of it is of the essence of the contract, the contract dies with him, and does not give rise to liability on the part of his personal representatives for its execution subsequent to his death; but an ordinary contract of a lease of a farm is not such a contract. ${ }^{54}$ In leasing a farm for agricultural purposes, its cultivation according to the course of good husbandry is implied. An outgoing tenant has no right to remove from the land he has occupied manure made on the land from its produce during his occupancy, and the fact that he has bought some hay and some grain and fed the grain so bought to his horses will not alter the case, so long as the manure so made is commingled with that made from the produce of the farm. ${ }^{55}$ There was. a suit to recover damages. He could have been restrained by writ of estrepement under the act of March 29, I822. ${ }^{56} \mathrm{~A}$ tenant from year to year is bound by law to treat a farm in a husbandman-like manner according to the custom of the

5x Collins $v$. Whilldin, 3 Phila. I02.

522 Addison on Contracts, 370.

53 Lewis $v$. Jones, I7 $\mathrm{Pa} .262$.

54 Walker's Est., 6 Pa. C. C. R. 515. 55 Lewis ข. Jones, 17 Pa. 262.

56 Barrington v. Justice, 2 Clarke, 50I. 
country, and when he does not, a court of common pleas will restrain him by writ of estrepement under the said act from doing any injury to the premises contrary to the custom. A writ of estrepement was issued because the tenant was plowing down sod and grass for the purpose of planting the land with corn, and the court refused to dissolve the writ. ${ }^{57}$ The fact that a farm is used as a milk farm, and not strictly for agricultural purposes, does not vary the rule against the removal of manure by a tenant. ${ }^{58}$

INABILITY OF TENANT TO DISPUTE THE TITLE OF HIS. LANDLORD.

\section{The Rule and its Operation.}

I39. As a general rule a tenant is not permitted to dispute his landlord's title. ${ }^{59}$ A tenant cannot resist his landlord's recovery in ejectment by virtue of an adverse title acquired during his lease. ${ }^{60}$ Nor can one who comes into possession under the tenant. ${ }^{61}$

\section{Liability of Tenant to Forfeit His Lease.}

I40. If a tenant disaffirms or impugns the title of his landlord, the landlord may elect to annul the lease. ${ }^{62}$ It is based on the fact that every lease contains a covenant express or implied, that the lessee will do nothing to impugn the lessor's right. ${ }^{63}$

\section{Case of Collusion with Tenant.}

I4I. An intruder can gain no advantage of a landlord by colluding with his tenant, and an adverse claimant who gets

57 Jones $v$. Whitehead, 4 Clarke, 330.

58 Waln $v$. Conner, 5 Clarke, I64.

59 Comyn on Landlord and Tenant, 519.

60 Galloway $v$. Ogle, 2 Binney, 468.

6i Graham v. Moore, 4 S. \& R. 466; Cooper v. Smith, 8 W. 536; McCleary v. Allen, 2 P. \& W. I44.

62 Newman $v$. Rutter, 8 Watts, 5 I.

63 Cole $v$. Bolard, $22 \mathrm{~Pa}$. 43I, 
possession of the land by tampering with his adversary's tenant stands in the tenant's place and cannot resist the landlord's title where the tenant himself could not. ${ }^{64}$

\section{Case of Fraud by the Landlord.}

I42. When fraud has been committed by the landlord, the tenant is permitted to impeach the lessor's title. ${ }^{65}$ The tenant may show that the title of the landlord no longer exists. $^{68}$

\section{SEALING AND EXECUTION OF LEASE, STAMPS AND RECORDING.}

\section{Where Landlord Does Not Sign Lease.}

I43. In England it has been held that if a tenant executes a lease containing covenants to pay rent and repair, but the landlord does not do so, and the tenant enters and pays rent, and the landlord conveys away the property, the purchaser cannot sue upon the lease, but if there is no such conveyance the tenant will be taken to have waived his right to an execution of the lease by the lessor as a condition precedent to his liability upon his covenants. ${ }^{67}$ A lessee accepted a lease signed by himself alone, took possession and paid rent and it was held that tenant was bound. The term of the lease was less than three years. ${ }^{68}$

\section{Where Tenant Does Not Sign Lease.}

I44. If a person who does not execute a lease, but enters and takes possession by force of the lease, he is deemed in law to have covenanted to hold upon the terms of the lease

64 Stewart $v$. Roderick, 4 W. \& S. I88; Prutzman $v$. Ferree, Io W. I43; Dikeman v. Parrish, $6 \mathrm{~Pa}$. 2 Io.

65 Boyer $v$. Smith, 5 Watts, 55; Brown v. Dysinger, I Rawle, 407.

66 Newell $v$. Gibbs, I W. \& S. 496.

672 Addison on Contracts, $\$ 695$.

68 Kaier v. Leahy, I5 Pa. C. C. R. 243. 
and to observe the conditions of the lease, and the lessor may distrain or bring an action for the arrears of rent. ${ }^{69}$

\section{Kind of Seal.}

145. In Pennsylvania an ink scroll or printed seal is sufficient to make a sealed document, excepting in case of a corporation which must use its corporate seal.

\section{Witnesses Required.}

I46. It is not necessary to have subscribing witnesses, but it is better and it seems to be necessary in some cases, as where a party signs by a mark, or in case there are erasures or interlineations to be noted.

\section{Erasures and Interlineations.}

I47. It is better not to have any erasures or interlineations, especially in any material part of the lease, but if there are any, they should all be carefully noted above the names of the attesting witnesses, otherwise the omission may prove fatal to a recovery or a remedy under the lease.

\section{Stamps on Leases.}

I48. The act of Congress of June I 3,1898 , requires stamps as follows: lease, agreement, memorandum, on contract for the hire, use or rent of any land, tenement or portion thereof. If for a period of time not exceeding one year, twenty-five cents; exceeding one year and not exceeding three years, fifty cents; if exceeding three years $\$ \mathrm{I}$. A receipt for rent of real estate which sets forth the terms as for a lease is required to be stamped as a lease, unless there is a lease in existence for the same purpose which has been already taxed. ${ }^{70}$ Where leases are executed in duplicate, each must be properly stamped. ${ }^{71}$ Leases executed and de-

692 Addison on Contracts, 694; Taylor's Landlord and Tenant, § 245; Gas. Co. v. Phila. Co., $158 \mathrm{~Pa}$. 317.

70 Treasury decision, 7 Pa. Dis. Rep. 436.

7 I Treasury decision, $7 \mathrm{~Pa}$. Dis. Rep. 453. 
livered prior to July I, I898, are exempt from taxation. An assignment of the unexpired term of a lease is taxable on the basis of the term assigned. ${ }^{72}$ The transfer of a lease is sub, ject to taxation for the unexpired term. ${ }^{73}$ Leases of rights of way are subject to taxation under act of June $13,1898 .^{74}$

\section{Recording.}

I49. If the lessee does not take actual possession of the demised premises there is danger of the lease being cut out as to a subsquent grantee without notice. ${ }^{78}$

72 Treasury decision, 7 Pa. Dis. Rep. 521.

73 Treasury decision, 7 Pa. Dis. Rep. 573.

74 Treasury decision, 7 Pa. Dis. Rep. 707.

75 Aye v. Phila. Co., 193 Pa. Rep. 457. 


\title{
CHAPTER II.
}

\author{
FIXTURES.
}

SECTION

I50. Domestic fixtures.

151. Trade fixtures.

152. Agricultural fixtures.

153. Fixtures not removed at the end of lease.

154. Tenant's fixtures liable to execution.
SECTION

I55. Notice te landlord upon constable's sale of a house as a trade fixture.

156. The duty of placing fire escapes in Philadelphia.

\section{Domestic Firtures.}

I 50. As to domestic fixtures there are but few cases in Pennsylvania. According to the ancient laws of England, a tenant was denied the right to remove fixtures put up for purposes of ornament or convenience, but it was afterwards settled that there were many ornamental fixtures which the tenant could remove, as hangings, looking-glasses, tapestry, stoves and grates fixed into the chimney with brickwork, cupboards supported by holdfasts, articles of domestic convenience slightly affixed, but the court refused to extend the privilege of ornamental fixtures to a conservatory erected on a brick foundation fifteen inches deep, attached to the wall of the dwellinghouse and said that it was "clear on the one hand that many things of an ornamental nature may be in a degree affixed and yet during the term may be removed; and, on the other hand, equally clear, there may be that sort of fixing or annexation which, though the thing annexed may have been merely for ornament, will yet make the removal of it waste." It has been said that four circumstances are pointed out as mainly essential to be regarded wherever the question is whether a 
fixture of an ornamental nature be removable. I. The mode in which and the extent to which it is united with the premises. 2. Its nature and construction; as whether it appear to have been intended as a temporary or as a permanent improvement. 3. Whether its removal is likely to occasion any considerable damage to the freehold. Lastly, whether there is any custom or prevalent usage applicable to the case in question. ${ }^{1}$ After reviewing a number of cases outside of Pennsylvania it has been stated that domestic fixtures useful or ornamental are removable by a tenant if their removal does not materially injure the dwelling. That at the present time the same favors are shown for domestic fixtures as those erected for trade purposes, although formerly the latter received the greater favor. ${ }^{2}$ If it is to be held that domestic fixtures are to be considered like trade fixtures such result will be very much to the prejudice and injury of landlords. Take for instance the case of a finely constructed mansion-house and put it in the same position as a factory building, the difference will be very marked. Whilst the walls, woodwork and floors of the factory building can be largely broken into for the purpose of placing fixtures and machinery, it might, in the case of the mansion, be ruinous to a fine wall, the floors, or woodwork to drive nails or to cut into them in any way. A fine mansion is like a piece of fine china or glassware. If the same is broken the beauty is impaired and repairing will not remedy the injury. Tenants now have liberal rights as to the removal of domestic fixtures, and, so much so, that landlords may need protection in their leases, and, considering that trade fixtures are favored merely on account of trade, there is no such reason why domestic fixtures should be so more than they were at common law.

\section{Trade Fixtures.}

I5I. In Pennsylvania, generally, great liberality has been

I Vol. 2, part I (8 Am. Ed.), Smith's Leading Cases, 210, 2 II.

28 Am. \& Eng. Ency. of Law, 57. 
shown by the courts in permitting tenants to remove trade fixtures. However, it is to be noted in the case of the renting of a hotel property, the master found that flooring, a frame addition used as a summer dining-room, an elevation to the house, comprising three bed chambers and a carving room, a cupboard, hitching posts and rails, fences, the material used in altering shedding into a carriage-house, registers and slate around the same, double glass doors, gas pipe, sinks and tin spouting, were all permanent improvements attached to the realty, and which the tenant could not remove. On exceptions the finding of the master was affirmed by the court below, and also by the Supreme Court on appeal. ${ }^{3} \mathrm{~A}$ range was erected for the business purposes of a restaurant. It was not affixed to the freehold except by being built against one of the walls. There was no evidence that it was intended to be a part of the realty. It was held to be the personal property of the tenant and that he had the right to sell it. ${ }^{4}$ Fixtures had been annexed to the freehold in a permanent manner by a tenant, and the Supreme Court remarked that under the earlier decisions, physical annexation was the test, but this doctrine no longer prevails. "That the true rule to be deduced from the authorities is, that it is not the character of the physical connection with the realty which constitutes the criterion of annexation, but it is the intention to annex. IVhen a tenant puts in fixtures or conveniences for his own comfort, the law raises no presumption that he intended them as permanent improvements, to be left for the benefit of his landlord, and, as a general rule, he will be entitled to remove them during his term. For any injury to the freehold by reason of such removal, he is, of course, liable to the landlord for damages." 5 An engine was fastened to the freehold and the boilers were masoned in and covered with brick-

3 Kenney's Ap., 22 W. N. C. 89.

4 Townsend $v$. Underhill, $6 \mathrm{~Pa}$. C. C. R. 544.

5 Seeger v. Pettit, $77 \mathrm{~Pa} .437$. 
work. The court regarded them as fixtures which the tenant could have removed at the end of his lease. ${ }^{6}$

Agricultural Fixtures.

I 52. The ancient English doctrine was that the rule as to trade fixtures did not extend to an agricultural tenant, but that distinction to some extent has been repudiated as not applicable to the circumstances of this country. In Pennsylvania it has lately been held that a tenant for years of farm lands comes within the rule that a tenant for years can remove trade fixtures. ${ }^{7}$

Fixtures Not Remored at the End of Lease.

I53. If a tenant upon the expiration of his lease does not remove his fixtures, they become the property of the landlord. It has been held that if a tenant at the close of his term renews his lease, he should take care to reserve his rights to remove fixtures as he had under the old tenancy, and that where a tenant sells his fixtures to an incoming tenant, he should obtain his landlord's consent. ${ }^{8}$

\section{Tenant's Fixtures Liable to Execution.}

I54. A tenant's trade fixtures are liable to be sold at sheriff's sale and severed by the purchaser. A boiler and engine being movable fixtures were so liable. ${ }^{9}$

\section{Notice to Landlord upon Constable's Sale of a House as a Trade Fixture.}

I 55. The object of a lease was to dig for flint; the tenants erected a frame building, connecting it with an old mill. A constable levied upon the building as a movable trade fixture or as personal property; before the constable sold, the tenant

6 Davis $v$. Moss, 38 Pa. 346; Hey 2 . Bruner, 6r Pa. 87; Hill $v$. Sewald, $53 \mathrm{~Pa} .27 \mathrm{I}$.

7 Carver $v$. Gough, $153 \mathrm{~Pa} .225$.

8 Taylor's Landlord and Tenant. $\$ \S 551,552,553$.

9 Hey $v$. Bruner, 6r Pa. 87; Kile v. Giebner, Ir4 Pa. 38I. 
surrendered his term to the landlord, who had no notice of the levy. Afterward the constable sold the house, but the purchaser could not remove it. The landlord should have had notice of the levy. The building was prima facie part of the real estate, and it put a creditor of the tenant upon his inquiry as to its character. ${ }^{10}$

The Duty of Placing Fire Escapes in Philadelphia.

I 56. The act of June 3, I883, in view of prior decisions of the courts, changes the law of June II, I879, so that the department of factory inspectors must proceed against the owner in fee or for life, and not the tenants of buildings not properly supplied with fire escapes. ${ }^{11}$

Io Thropp's Ap., $70 \mathrm{~Pa}$. 395.

II In re Fire Escapes, $2 \mathrm{~Pa}$. D. R. 298; In re Fire Escapes, $12 \mathrm{~Pa}$. c. C. R. 525 . 


\section{CHAPTER III.}

\section{SECURITY FOR RENT.}

SECTION

I57. Where surety is liable to be sued at once.

I58. Covenant of suretyship runs with the land.

I59. Tenant bound to exonerate surety.

I60. Position of surety in case of a tenant holding over.

I6r. Alteration of lease as it affects surety.
SECTION

162. Discharge of surety by variation of lease.

163. Discharge of surety if landlord allows goods distrained to be removed.

164. Demand of rent by landlord. 165. Discharge of surety by giving time.

I66. Surety liable under a void lease.

Where Surety is Liable to be Sued at Once.

I57. By an agreement the defendant covenanted to be responsible for the performance of the terms and conditions of the lease on the part of the lessee. The lease contained a covenant to pay a certain money rent at stipulated times; it was held that the defendant was not a guarantor merely, but a surety; therefore, liable for the rent at once without showing the tenant's insolvency. ${ }^{1}$

Covenant of Suretyship Runs with the Land.

I 58. A covenant of suretyship runs with the land and may be sued on by the assignee of the reversion. ${ }^{2}$

\section{Tenant Bound to Exonerate Surety.}

I59. As soon as the surety's obligation to pay becomes absolute, he is entitled in equity to require the principal debtor to exonerate him, and he may at once file a bill to

I Korn v. Hohl, $80 \mathrm{~Pa}$. 333; Reigart $v$. White, $52 \mathrm{~Pa} .438$.

2 Taylor $v$. Kennelly, I4 W. N. C. I24. 
compel an exoneration, although the creditor has not demanded payment from him. ${ }^{3}$

\section{Position of Surety in Case of a Tenant Holding Over.}

I60. A surety became bound for a tenant's performance of contract of lease for one year, the rent being payable monthly, and if the tenant continued after the term, the contract to continue for another year and so on from year to year until legal notice was given for removal. Held, if the tenant held over the year, the surety was responsible for the subsequent rent. ${ }^{4}$ A lease was for a year, either party might determine it at the end of the term by giving a 'month's previous notice. A surety for the lessee gave due notice to the lessor that he would not be bound beyond the end of the current year. The lessee held over; the surety died before the end of the succeeding year. Held, his estate was not liable for the rent during that year; that it was inequitable to the surety to continue the tenant for another year after the notice. Equity often relieves a surety when the principal would not be relieved. The death of the surety was considered in deciding the case. ${ }^{5}$ A contract of suretyship, binding upon heirs, executors and administrators during a present or future period will not be revoked by the death of the surety. 6

\section{Alteration of Lease as it Affects Surety.}

I6I. When the parties to a contract materially alter it, without the consent of the surety, the latter will be released from liability. There must be a binding agreement; mere indulgence will not be sufficient. ${ }^{7}$ The mere fact that the landlord occupied part of the demised premises for a portion

3 Oil Co. v. Mining Co., $66 \mathrm{~Pa} 375$.

4 Coe $v$. Vogdes, 7 I Pa. 383.

5 Pleasanton's Ap., 75 Pa. 344.

6 Bank v. Yard, I50 Pa. 35I.

7 Whelen v. Boyd, II4 Pa. 228. 
of the year with the consent of the tenant, no change having been made in the contract, does not release the surety. ${ }^{8}$

\section{Discharge of Surety by Variation of Lease.}

162. In such case the tenant will be discharged. ${ }^{9} \mathrm{~A}$ reduction of rent will not discharge him. ${ }^{\mathbf{1 0}}$

Discharge of Surety if Landlord Allows Goods Distrained to be Removed.

163. If a landlord after distraining on goods, allow the tenant to remove them, the surety will be discharged to the value of the goods distrained. ${ }^{11}$ If the goods should be eloigned by the tenant without any negligence upon the part of the landlord or the bailiff, the surety will not be discharged. ${ }^{12}$

\section{Demand of Rent by Landlord.}

I64. No previous demand of the landlord for the rent is necessary. ${ }^{13}$

\section{Discharge of Surety by Giving Time.}

I65. A surety will be discharged by an agreement of the landlord which can be enforced at law or in equity, whereby he extends the time of payment for any definite period, but a mere consent to forbear for a loose and uncertain period will not discharge the surety. ${ }^{14}$

\section{Surety Liable under a Void Lease.}

I66. The defendant contended that a lease which he signed as surety, was not in law a lease for five years, because it was not signed by the lessor and that for that reason he was not

8 Medary $v$. Cathers, I6r Pa. 87.

9 Barnes $v$. Carney, 6 W. N. C. 448.

ro Flanigan $v$. Rossiter, 7 W. N. C. I80; Dickson $v$. Wolf, 5 W. N. C. 37 .

I I McNamee v. Cresson, 3 W. N. C. 450.

I2 Myers $v$. Hulseman, 3 W. N. C. 487.

13 Haynes $v$. Synnott, 34 W. N. C. 107.

14 Bank v. Legrand, I03 $\mathrm{Pa} .309$. 
liable as surety. The defendant's obligation was "to be responsible to the above-named lessor for the true and faithful performance of the above contracts, covenants and agreements on the part of the above-named lessee, for the full time in which he may retain possession of said premises under the above agreement." The lessee entered under the lease. It was held that so long as the tenant remained in possession, the surety was liable. ${ }^{15}$

15 Duffee v. Mansfield, I4I Pa. 507. 
TRANSFERS OF INTERESTS OF LANDLORDS IN DEMISED PREMISES.

SECTION

167. By a sale and conveyance of the demised premises.

168. $\mathrm{By}$ an assignment of the landlord for the benefit of creditors.

169. By a conveyance to a trustee to collect rents, etc.

170. By a judicial sale.

I7I. Notice of affirmation of lease to be given to tenant.
SECTION

172. When lease antedates incumbrance, lease preserved.

173. When rent is paid in advance.

174. Rent before and after date of sheriff's deed.

175. The right of a purchaser at an orphans' court sale to rents or possession.

176. Transfer by the will of the landlord.

I77. Transfer by descent.

By a Sale and Conveyance of the Demised Premises.

I67. Upon the delivery of a deed to the vendee he becomes the landlord of the vendee's tenants and entitled to receive the rents due after such delivery. He should give notice to the tenants of the delivery of the deed and request them to pay to him the future rent. If the vendor has a written lease it should be assigned and delivered to the vendee. By a custom rents of tenants are apportioned to the date of settlement. It will be well in an agreement for purchase to have it stated that the rents are to be apportioned to a date of settlement; if such is the intention. On March 22, I899. the plaintiffs agreed to sell a lot to the defendants on April 22, I899, subject to all the terms of the lease, and on April I, I899, the rent for the quarter then beginning was paid to the plaintiff. The defendant claimed that he was entitled to rent for May and June. When the defendant got his deed he knew 
there would be no rent until July I, 1899. It was held that the vendor was not liable to pay the vendee any part of the rent received April I. It was held that rent was not apportionable at law or in equity. It does not accrue de die in diem. The rent belonged to the vendor, as the legal title was in him when it accrued. That the vendor is a trustee for his vendee to convey to the vendee, makes no difference. ${ }^{1}$

\section{By an Assignment of the Landlord for the Benefit of Creditors.}

I68. In the deed of assignment there is usually inserted a clause providing for the sale of the property of the assignor. When such sale is made and the deed delivered to purchaser, the purchaser becomes the landlord of the assignor's tenants, but until such sale and conveyance the assignor can remain in possession of real estate and collect the rents. The assignee is not chargeable with the rental thereof. ${ }^{2}$

\section{By a Conveyance to a Trustee to Collect Rents, etc.}

I69. In such case the tenant should see that the trustee has express or implied authority to collect the rent, etc. It may happen in the course of time that the power of the trustee to collect the rents will cease in a change of the trusts. A copy of the trusts of the deed can be obtained and referred to from time to time to see if the trusts still continue.

\section{By a Judicial Sale.}

I70. When a purchaser at sheriff's sale gives notice for possession it is provided that, "Whenever any lands or tenements shall be sold by virtue of any execution as aforesaid, the purchaser of such estate may, after the acknowledgment of a deed therefor to him by the sheriff, give notice to the defendant, as whose property the same shall have been sold, or to the persons in possession of such estate under him, by title derived from him subsequently to the judgment under

I Singer v. Solomon, vol. 56, Leg. Int. 315, $8 \mathrm{~Pa}$. Dis. 402.

2 Detwiler's Ap., 96 Pa. 323; Breneman's Est., I50 Pa. 494. 
which the same were sold, and require him or them to surrender the possession thereof to him within three months from the date of such notice; ${ }^{3}$ and it is provided that, "If any lands or tenements shall be sold upon execution, as aforesaid, which at the time of such sale, or afterwards, shall be held or possessed by a tenant or lessee, or person holding, or claiming to hold the same under the defendant in such execution, the purchaser of such lands or tenements shall, upon receiving a deed for the same, as aforesaid, be deemed the landlord of such tenant, lessee, or other person, and shall have the like remedies to recover any rents or sums accruing subsequently to the acknowledgment of a deed to him, as aforesaid, whether such accruing rent may have been paid in advance or not, if paid after the rendition of the judgment on which sale was made, as such defendant might have had, if no such sale had been made." 4 In case a clemised property is sold at sheriff's sale upon execution, the purchaser has the option either to disaffirm the lease by giving three months' notice to quit from the date of the notice, or to affirm the lease, and avail himself of the rights of the former owner to recover the rent. If the purchaser does not choose to affirm the lease, he may recover for use and occupation during the time the tenant holds over. ${ }^{5}$

\section{Notice of Affirmation of Lease to be Given to Tenant.}

I 7 I. In case the lease is affirmed, notice should be given immediately to the tenant.

\section{When Lease Antedates Incumbrance, Lease Preserved.}

172. A purchaser at sheriff's sale under a judgment on a mortgage, by giving notice to quit to a tenant holding under a lease subsequent to the mortgage, disaffirms the lease and determines the tenancy; but in case of a lease made before a

3 Act June I6, 1836, P. \& L. Dig. 1987; P. L. 755, § 105.

4 Act June 16, I836, P. \& L. Dig. I993; P. L. 755, § 119.

5 Stockton's Ap., 64 Pa. 58. 
mortgage, the purchaser takes as assignee of the reversion, and the relation necessarily continues. ${ }^{6}$

\section{When Rent is Paid in Advance.}

I73. The lease may be disaffirmed, although the rent has been paid in advance. ${ }^{7}$

\section{Rent Before and After Date of Sheriff's Deed.}

174. The purchaser, in case he elects to affirm the lease, is entitled to the rent accruing after the acknowledgment of the sheriff's deed. ${ }^{8}$ Rent accruing between the date of the sheriff's sale and the acknowledgment of the sheriff's deed can be attached as the defendant's. ${ }^{9}$ Such rent, though payable in advance will not go to the purchaser. ${ }^{10}$

The Right of a Purchaser at an Orphans' Court Sale to Rents or Possession.

I75. By the act of April, I849, it is provided that after the confirmation of the sale and execution, and acknowledgment of the deed, a purchaser at an orphans' court sale shall have the right to obtain possession of the premises by proceeding in the same manner as provided in relation to sheriff's sales. The decree confirming the orphans' court sale does not operate of itself to transfer the title, and hence the title of the heirs is not divested by such sale until the purchaser has complied with the terms of sale and received his deed for the premises purchased. Wherefore, the heirs of a decedent are entitled to the rents accruing between the date of confirmation of an orphans' court sale and the date when the deed is delivered to the purchaser; and the payment of such rents to the purchaser is no defence to an action by the heirs therefor. ${ }^{11}$

6 Hemphill $v$. Tevis, 4 W. \& S. 535.

7 Market Co. $v$. Lutz, 4 Phila. 322.

8 Garrett $v$. Dewart, $43 \mathrm{~Pa} .342$.

9 Bank $v$. Hanson, i W. N. C. 6r3.

Io Bank v. Ege, 9 W. 436; Fullerton v. Shauffer, I2 Pa. 220.

II Strange $v$. Austin, I34 Pa. 96 . 
Transfer by the Will of the Landlord.

I76. In case a landlord should die leaving a will and thereby devising real estate directly and absolutely to devisees, they will become landlords in the place of the testator and will be entitled to collect rent falling due after his decease. However, in case such devisees should be minors, they should have a guardian appointed to act for them. In case such devisees should only have a life estate, then those entitled to the remainder will have the right to the rents upon his decease. In case of a devise to trustees who will be entitled to the rents it should be ascertained when such rights will terminate.

\section{Transfer by Descent.}

I77. In case a landlord dies without a will, a tenant will have to pay his rent to his heirs, according to their rights under the intestate laws. Consequently, it becomes important to consider such laws.

The act of April 8, I833, ${ }^{12}$ provides as follows:

Widow and Issue (Sec. I, Art. I).- "Where such intestate shall leave a widow and issue, the widow shall be entitled to one-third part of the real estate for the term of her life, and to one-third part of the personal estate absolutely."

Widow and Collateral Heirs (Sec. I, Art. II)."Where such intestate shall leave a widow and collateral heirs, or other kindred, but no issue, the widow shall be entitled to one-half part of the real estate, including the mansion house and buildings appurtenant thereto, for the term of her life, and to one-half part of the personal property absolutely."

Husband and Heirs (Sec. I, Art. III).- -Where such intestate shall leave a husband, he shall take the whole personal estate, and the real estate shall pass as hereinbefore provided, saving to the husband his right as tenant, by the

12 I P. \& L. Dig. 2407; P. L. 1833, 315. 
curtesy which shall take place, although there be no issue of the marriage, in all cases where the issue, if any, would have inherited."

Interest of Lineal Descendants (Sec. 2).- "That subject to the estates and interests hereinbefore given to the widow or surviving husband, if any, the real estate of such intestate shall descend to, and personal estate not otherwise hereinbefore disposed of, shall be distributed among his issue, according to the following rules and order of succession, viz.:"

Children Only (Sec. 2, Art. I).- “If such intestate shall leave children, but no other descendant being the issue of a deceased child, the estate shall descend to and be distributed among such children."

Grandchildren Only (Sec. 2, Art. II).- "If such intestate shall leave grandchildren or other descendant being the issue of a deceased grandchild, the estate shall descend to and be distributed among such grandchildren."

Other Lineal Descendants in Same Decree (Sec. 2 , Art. III).-." "If such intestate shall leave descendants in any other degree of consanguinity, however remote from him, and all in the same degree of consanguinity to him, the estate shall descend to and be distributed among such descendants."

Descendants in Different Degrees (Sec. 2, Art. IV). - "If such intestate shall leave descendants in different degrees of consanguinity to him, the more remote of them being the issue of a deceased child, grandchild or other descendant, the estate shall descend to and be distributed among them as follows, viz. :"

Children and Grandchildren (A)._- "Each of the children of such intestate shall receive such share as such child would have received, if all the children of the estate, who shall then be dead, leaving issue, had been living at the death of the intestate."

Grandchildren and Great-Grandchildren, Etc. (B). - "Each of the grandchildren, if there shall be no children, 
in like manner shall receive such share as he or she would have received if all the other grandchildren who shall then be dead, leaving issue, had been living at the death of the intestate, and so in like manner to the remotest degree."

The Issue of Descendants to Take by RepresentaTION (C).- "In every such case, the issue of such deceased, grandchild or other descendant, shall take by representation of their parents respectively, such share only as would have descended to such parent, if they had been living at the death of the intestate."

Interest of Father AND Mother (Sec. 3).--"In default of issue as aforesaid, and subject also as aforesaid to the estates and interests hereinbefore given to the widow or surviving husband, if any, the real estate shall go to the father and mother of such intestate, during their joint lives, and the life of the survivor of them; and the personal estate not otherwise hereinbefore disposed of, shall be vested in them absolutely, or if either the father or mother be dead at the time of the death of the intestate, the parent surviving such intestate shall enjoy such real estate during his or her life, and such personal property absolutely."

INTEREST OF Brothers AND Sisters AND THEIR DeSCENDANTS (Sec. 4).- "In default of issue as aforesaid, and subject to the estates and interests hereinbefore given to the widow or surviving husband, father and mother, of the intestate, if any, the real estate shall descend to, and the personal estate not otherwise hereinbefore disposed of, shall be distributed among collateral heirs and kindred of such intestate, according to the following rules and order of succession, viz.:"

Brothers and Sisters of the Whole Rlood (Sec. 4. Art. I).-." "If such intestate shall leave brothers and sisters or either of the whole blood, and no nephew or niece being the issue of a deceased brother or sister of the whole blood, the real estate shall descend to and vest in such brothers and sisters." 
Children of such Brothers and Sisters Deceased (Sec. 4, Art. II).-.."If such intestate shall leave neither brother nor sister of the whole blood, but nephews or nieces being the children of such deceased brother or sister, the real estate shall descend to and vest in such nephews and nieces."

Brothers and Sisters of the Whole Blood and Children of such Deceased (Sec. 4, Art. III).- " If such intestate shall leave brothers and sisters of the whole blood, and also nephews or nieces being the children of any such deceased brother or sister, the real estate shall descend to and vest in such brothers and sisters and nephews and nieces as follows, viz.: Every such brother and sister shall receive such share as he or she would have received, if all the brothers and sisters who shall then be dead, leaving children, had been living at the death of the intestate, and such nephews and nieces shall take by representation of their parents respectively, such share only as would have descended to such parents if they had been living, at the death of the intestate."

Other Descendants of such Brother or Sister (Sec. 4, Art. IV).- "If such intestate shall leave neither brother nor sister of the whole blood, nor any nephew or niece, being the child of such deceased brother or sister, the real estate shall descend to and vest in the next of kin of such intestate, being the descendants of his brothers and sisters of the whole blood."

Personal Estate, Brothers and Sisters of the Whole and Half Blood (Sec. 4, Art. V).- "The personal estate of such intestate not otherwise hereinbefore disposed of, shall in the several cases mentioned in this section, be distributed among the brothers and sisters of the intestate, and their issue in like manner in each of the said cases as is provided for the descent and division of the real estate of the intestate. but without any distinction of blood."

In Default of Persons Entitled to Real Estate as 
Before, Same to go to Father and Mother (Sec. 5).- “ín default of issue, and brothers and sisters of the whole blood and descendants as aforesaid, and subject to the estates and interests hereinbefore given to the widow or surviving husband, if any, the real estate shall go to and be vested in the father or mother of the intestate, or if both be living at the time of his death, in the father and mother, for such estate as the said intestate had therein."

In Default of Such, Real Estate to go to Brothers and Sisters of the Half Bloon (Sec. 6).- "In default of issue and brothers and sisters of the whole blood and their descendants, and also of father and mother, competent by this act, to take an estate of inheritance therein, the real estate of such intestate, subject to the life estates hereinbefore given, if any shall descend to and be vested in the brothers and sisters of the half blood of the intestate and their issue in like manner respectively, as is hereinbefore provided for the case of brothers and sisters of the whole blood and their issue."

The Next of Kin (Sec. 7).- "In default of all persons hereinbefore described, the real and personal estate of the intestate shall descend to and be distributed among the next of kin to such intestate."

Representation amongst Collaterals Limited (Sec. 8).- "Provided, That there shall be no representation admitted amongst collaterals after brothers' and sisters' children."

Inheritance of Real Estate to Persons of the Blood of THE Ancestors (Sec. 9).-_"Provided also, That no person who is not of the blood of the ancestors or other relations from whom any real estate descended, or by whom it was given or devised to the intestate, shall in any. cases before mentioned, take any estate of inheritance therein, but such real estate subject to such life estate as may be in existence by virtue of this act, shall pass to and vest in such persons as would be entitled by this act, if the persons not of the blood 
of such ancestor or other relation had never existed, or were dead at the decease of the intestate."

When the Surviving Husband or Wife Takes the Whole Estate (Sec. IO).- "In default of known heirs or kindred competent as aforesaid, the real estate of such intestate shall be vested in his widow, or if such intestate were a married woman in her surviving husband for such estate as the intestate had therein, and in such case the widow shall be entitled to the whole of personal estate absolutely."

Of Escheats to Commonwealth (Sec. 12).- "In default of all known heirs, or kindred, widow or surviving husband as aforesaid, the real and personal estate of such intestate shall go to and be vested in the commonwealth by escheat."

Certain Collaterals to Take by Representation.By the act of April 27, 1855, "Among collaterals, when by existing laws entitled to inherit, the real and personal estate shall descend and be distributed among the grandchildren of brothers and sisters, and the children of uncles and aunts, by representation; such descendants taking equally among them such share as their parent would have taken if living."

Descendants of Grandparents to Take by RepresenTAtion as Next of Kin.-By the act of May 25, I887, ${ }^{14}$ provision is made for the descent to descendants of grandparents by representation when the grandparents would have taken as next of kin, but real estate in such cases to vest in persons of the blood of the ancestor from whom it was derived.

Adopting Parents and Adopted Child to Inherit From EAch OTHer.-By the act of April I3, I887, ${ }^{15}$ provision is made for such inheritance. There is a provision of this law that it shall only apply to such property as the adopted child shall have inherited or derived from the adopting parents or their kindred.

Inheritance in Case of Illegitimate Children.-By

13 I P. \& L. Dig 2413; P. L. $1855, \S 2,368$.

14 I P. \& L. Dig. 2413; P. L. 1887 , 26 I.

I5 I P. \& L. Dig. 2416; P. L. $1887,53$. 
the act of April 27. I855. ${ }^{16}$ illegitimate children and their mother inherit from each other, and by the act of June 5 , ${ }^{1} 88_{3},{ }^{17}$ illegitimate children, born of the same mother, and leaving neither mother nor issue, are capable of inheriting, strviving inherit from each other.

Husband's Rights Lost by Desertion.-By the act of May $4,1855,{ }^{18}$ if a husband deserts his wife or neglects to provide for her for one year previously to her death, he will lose his rights to his wife's property under the intestate laws and as tenant by the curtesy.

Husband's Rights to Personal Property, Wife Leaving Children.- "If a married woman leave a child or children living, her personal estate shall be divided amongst the husband and such child or children, share and share alike; if any such child or children being dead, shall have left issue, such issue shall be entitled to the share of the parent." 19

I6 I P \& L. Dig. 2420; P. L. I885, 368.

17 I P. \& L. Dig. 2420; P. L. $1883,88$.

I 8 I P. \& L. Dig. 2902; P. L. I885, 430.

19 Act April I1, 1848, I P. \& L. Dig. 1068; P. L. 537. 


\section{CHAPTER V.}

TRANSFERS OF INTERESTS OF TENANTS IN DEMISED PREMISES.

Assignuent of Lease by TenANT AND UNDERLETTING.

SECTION

178. Leases not to be assigned except by writing.

I79. Difference between assignments and underletting.

ISo. Position of under-tenant.

sSI. Power of tenant to assign or underlet.

182. Tenant bound to pay rent after he assigns his lease.

I83. Assignee liable as long as he holds title.

184. Implied indemnity of assignee.

185. Implied indemnity of tenant to under-tenant.

Assignment of Lease wilex TENant Dies.

186. A lease a part of decedent's assets.
SECTION

187. When representatives become personally liable.

Lease in case of an Assignment FOR THE BENEFIT OF Creditors.

188. Assignee for the benefit of creditors has the right to accept lease or not.

I89. Landlord's preference under the act of $189 I$, in case of assignments for the benefit of creditors.

190. Agreement of assignee with sheriff for sale of goods.

191. Liability of assignee for rent.

Sileriff's Levy and Sale of a LEASE.

192. Practice as to levy and sale.

\section{ASSIGNMENT OF LEASE BY TENANT AND UNDERLETTING.}

\section{Leases Not to be Assigned Except by Writing.}

I78. Leases and term of years are not to be assigned by landlords unless by writing or by their agents unless they are authorized by writing. ${ }^{1}$

I Act March 21, 1772, I P. \& L. Dig. 2190; I Sm. L. 389. 


\section{Difference between Assignments and Underletting.}

179. An assignment of lease is where the whole term is transferred by a tenant. An underletting is where a tenant transfers less than his whole term. The distinction between an assignment and an underletting depends solely upon the question of interest which passes, and not upon the extent of the premises transferred. Where, therefore, the lessee of a house for seven years demised part of the house to another for the whole of his term, this is not an under-lease but an assignment pro tanto; and so, on the other hand, where the lessee of a house for seven years demised the whole of the house for seven years, all but one day, this is an underlease and not an assignment. ${ }^{2}$

\section{Position of Under-Tenant.}

I80. Every under-lessee becomes tenant to the lessee who grants the under lease, and not tenant to the original lessor. Between him and the under-lessee no privity is said to exist.

\section{Power of Tenant to Assign or Underlet.}

I8I. A tenant may either assign or underlet. ${ }^{3}$ A covenant not to assign is not broken by an underletting.

\section{Tenant Bound to Pay Rent After He Assigns His Lease.}

I82. In case a tenant covenants to pay rent, his liability to pay rent upon the covenant lasts, although he assigns his lease and the landlord accepts rent from the assignee. ${ }^{4}$

\section{Assignee Liable as Long as He Holds Title.}

183. An assignee of a lease is personally liable to the head landord for the rent so long as he holds the lease. By assigning the lease he may get rid of any liability for rent falling due after the assignment. A tenant acquiring the leasehold by assignment of the lease is charged with notice of its covenants,

2 Comyn on Landlord and Tenant, 52.

32 Hilliard on Contracts, 63. 4 Frank v. Maguire, $42 \mathrm{~Pa} .77$. 
and he takes the estate of the assignor subject to them. But his liability grows out of privity of estate. It ceases when the privity ceases. If he has assigned before the time for performance, his liability would have ceased with his title, and the liability would have attached to his assignee by reason of privity of estate. Each successive assignee would be liable for covenants maturing while the title was held by him, because of privity of estate; but he would not be liable for those previously broken or subsequently maturing, because of the absence of any contract relations with the lessor. While he holds the estate and enjoys its benefits he bears its burdens, but he lays down both the estate and burdens by an assignment, even though, as it is said in some of the cases, if the assignment be to a beggar. ${ }^{\circ}$

\section{Implied Indemnity of Assignee.}

I84. A lessee who assigns is entitled to be indemnified by his assignee against the non-payment of rent and the nonperformance of the covenants in the original lease, since his liability continues although he is not in possession.

\section{Implied Indemnity of Tenant to Under-Tenant.}

I85. When a tenant underlets, the law implies a duty on his part to indemnify the under-tenant against all his covenants with the superior landlord, and the under-tenant may have an action on the case against him for any injury he may sustain by reason of any such breach of contract.

\section{ASSIGNMENT OF LEASE WHEN TENANT DIES.}

\section{A Lease a Part of Decedent's Assets.}

186. When a tenant dies, a lease to him will vest in his executors or administrators as personal property. A goodwill is the probability that the old customers will resort to the old place, and cannot be distinguished or separated from

5 Goss v. Brick Co., 4 Super. Ct. Rep. 167. 
the lease of the house. ${ }^{6}$ Consequently the good-will will tend to enhance the value of the lease. The good-will of an inn does not exist independently of the house in which it is kept. ${ }^{7}$ Generally the first duty of an executor or administrator is to sell the lease with the good-will, if they are worth anything. It was held that it is the duty of an executor to sell and dispose of, for the benefit of the creditors of the estate, a goodwill and unexpired term owned by the decedent in his lifetime. $^{8}$

\section{When Representatives Become Personally Liable.}

I87. If the executors or administrators take possession and use the demised premises they will become personally liable as assignees; but they may get rid of this liability at any time by an assignment of the lease. In case a lease is worthless, it may be best to get the landlord to accept a surrender of the lease and to release the estate.

\section{LEASE IN CASE OF AN ASSIGNMENT FOR THE BENEFIT OF. CREDITORS.}

Assignee for the Benefit of Creditors Has the Right to Accept Leags or Not.

188. Trustees under an assignment for the benefit of creditors are entitled to a reasonable time to ascertain whether or not property, held under a lease by the debtor can be made available for the benefit of creditors; they may, there: fore, offer it for sale, and make an experiment to see if the lease be beneficial for the estate, without incurring liability. If an assignee take possession, assume the management of the premises, or do some other act indicating an intention to accept the assignment of the lease, he becomes liable upon the lessee's covenants. Until the assignee accepts the term, it remains in the bankrupt. If the assignee accept the lease,

6 I Ḣofiman's Chancery, 68.

7 Elliott's Ap., $60 \mathrm{~Pa}$. 161 .

8 Coppel's Est., 4 Phila. 378; Wiley's Ap., 8 W. \& S. 244. 
he may rid himself of future claims by assigning over as other assignees may. ${ }^{9}$ There was a lease from year to year, which was not assignable without the consent of the landlord. On May 27,1822 , the tenants made an assignment for the benefit of creditors. The assignees took an inventory and possession of the goods in the store, took the key, and made a public sale in the store. The assignors remained in the dwelling part of the house until June I2, I822. On July 4, I 822, the assignees tendered the key of the demised premiseswhich the landlord refused to accept-and paid one quarter's rent, and declared that they had made no other use of the premises than to make the public sale. It was held that the assignees were not liable to pay rent which became due after the date of the assignment. That if the lease was valuable, they were bound to do the best with it for the estate, but that assignees may elect or refuse to take a lease. ${ }^{10}$ Where the landlord seeks to enforce a claim based on an alleged election by the assignee to hold the lease for the benefit and at the expense of the estate, it is incumbent on him to prove by clear and satisfactory evidence an express agreement by the assignee to so hold it, or conduct on the part of the assignee from which there is a plain and necessary implication that he elected to do so. The bare possession of the leased premises for a comparatively brief time, for the purpose of disposing of the stock of merchandise on the premises at the time of the assignment, is insufficient to indicate an acceptance of a lease by the assignee. ${ }^{11}$

\section{Iandlord's Preference under the Act of 1891, in Case of Assignmenti for the Benefit of Creditors.}

I89. The act of assembly of May 26, I89I, provides for the payment of rent in case of assignments for the benefit of creditors. Where goods are assigned which are liable for

9 Taylor's Landlord and Tenant, § 458 .

so Pratt $v$. Levan, I Miles, 358.

II Weinmann's Est., I64 Pa. 405. 
distress for rent the landlord will be first entitled to receive. out of the proceeds of the sale of such goods by the assignee. his rent due him at the time of the making of the assignment not exceeding one year's rent. If the proceeds of the sale shall not be sufficient to pay the landlord and the costs of the assignment, he will be entitled to receive the proceeds of the sale after deducting so much for costs as he would be liable to pay in case of a sale under a distress. ${ }^{11 *}$

\section{Agreement of Assignee with Sheriff for Sale of Goods.}

190. An assignee for the benefit of creditors, executioncreditors and the sheriff may agree that the assignee shall sell. The assignee may agree to protect the landlord to the extent that he could be protected by a landlord's warrant. The landlord can give notice to the assignee of his claim for rent. ${ }^{12}$

\section{Liability of Assignee for Rent.}

191. An assigned estate was not liable for rent of premises which had been occupied by the assignor, but which the assignee had never taken possession of, and which accrued after the date of the assignment. ${ }^{13}$

\section{SHERIFF'S LEVY AND SALE OF A LEASE.}

\section{Practice as to Levy and Sale.}

I92. A leasehold, being a chattel real, by reason of its fixed and permanent character, can, under an execution, be seized and held only as real estate, not as personal goods. susceptible of transportation. The levy of a leasehold can be only by description of the realty out of which it issues. Under a $f$. fa. against a lessee, the sheriff went upon the premises leased, examined them, etc.; afterwards, out of view of them, he endorsed a description of them on his writ, and returned that he had levied on them. Held, a good levy. ${ }^{14}$

II* I P. \& L. Dig. 212; 1891, P. L. I22.

I2 Leidich's Est., I6r Pa. 45r.

13 Assigned Est. of Snyder, 8 Phila. 302.

14 Iron Works Ap., $77 \mathrm{~Pa}$. 103. 


\section{CHAPTER VI.}

POWERS OF TENANT AND LANDLORD TO MORTGAGE.

SECTION

193. Powers under the act of 1855 .

194. Lease must be recorded.

195. Machinery put in after mortgage.

196. Mortgage a breach of covenant not to assign.

197. The act is not restricted to mining leases.
SECTION

198. Fixtures and machinery cannot be removed without consent of mortgagee.

199. Act of 1853 as to mortgages of mines.

200. Act of I89I as to mortgages of ores, etc.

20I. Mortgages of rentals or royalty.

\section{Powers under the Act of 1855 .}

193. By the act of April 27, I855, every lessee for a term of years of any colliery, mining land, manufactory or other premises may mortgage his lease with all buildings, fixtures and machinery thereon with the same effect as in case of the mortgaging of a freehold interest and title as to lien, notice, evidence and priority of payment, provided that the mortgage be acknowledged and recorded together with the lease; provided that such mortgage shall in no wise interfere with the landlord's rights, priority or remedy for rent. ${ }^{1}$

\section{Lease Must be Recorded.}

194. The lease must be recorded with the mortgage. ${ }^{1 *} \mathrm{~A}$ copy of a lease recorded, referring to the record of the lease, will be sufficient. ${ }^{2}$

I I P. \& L. Dig. I607; I855, P. L. 368.

I* Sturtevant's Ap., $34 \mathrm{~Pa}$. I49.

2 Ladley $v$. Creighton, $70 \mathrm{~Pa} .490$. 
Machinery Put In After Mortgage.

195: A mortgage under the act will bind machinery brought into a mill after the execution and recording of the mortgage. ${ }^{2 *}$

Mortgage a Breach of Covenant Not to Assign.

196. A mortgage of a leasehold amounts to an assignment of the term within the meaning of a clause making an assignment a ground of forfeiture. ${ }^{3}$

\section{The Act is Not Restricted to Mining Leases.}

197. In view of the remedial purposes of the statute, and the general expression contained in the subsequent acts of April 3, I868, and May I3, I876, the words "or other premises" are not to be restricted to colliery, mining or manufacturing leaseholds. A leasehold interest in a city lot for a term of years, the lessee paying a yearly rent and taxes, and being required to erect a building thereon, was within the operation of the act: Under the act on the failure of a mort. gagee of a leasehold either to record the lease with his mortgage, or to cause full and distinct references to be made it the mortgage to the book and page where the lease is there recorded, it was held that the mortgage was without lien."

\section{Fixtures and Machinery Cannot be Removed Without Consent of Mortgagee.}

198. The act of April 27, I855, gives to a mortgage thereunder the same force and effect as a mortgage of real estate, and gives the mortgagee like remedies for protection and enforcement of his security. The fixtures and machinery cannot be removed to the detriment of the mortgagee ever though the mortgage should not be due, unless the mortgagee has provided against it by reserving to himself the pos-

2* Ladley $\%$. Creighton, 7o Pa. 490.

3 Becker $v$. Werner, $98 \mathrm{~Pa} .555$.

4 Hilton's Ap., II6 Pa. 35I. 
session and control of the mortgaged property until default is made in payment of the mortgage debt."

Act of 1853 as to Mortgages of Mines.

199. The act of April 5, 1853, authorizes tenants of coal mines in Schuylkill county to mortgage their leases, fixtures, etc., as provided in the law."

Act of 1891 as to Mortgages of Ores, etc.

200. The act of May 20, $189 \mathrm{I}$, provides for the mortgaging of iron ore, iron, oil, gas, etc., to be mortgaged as therein provided. It also provides for the mortgaging of coal leases, etc., as therein prescribed. ${ }^{\top}$

\section{Mortgages of Rentals or Royalty.}

201. By act of May I3, I889, rentals and royalties of mines may be mortgaged as provided. ${ }^{8}$

5 Gill v. Weston, I10 Pa. 312.

6 I P. \& L. Dig. 1605; P. L. 295.

7 I P. \& L. Dig. I608; P. L. 102.

8 I P. \& L. Dig. I611; P. L. 197. 


\section{CHAPTER VII.}

THE RECOVERY OF POSSESSION OF DEMISED PREMISES UNDER THE ACT OF APRIL 3, I830, FOR THE NON-PAYMENT OF RENT.

SECTION

202. The act of 1830 .

203. Who may have the benefit of the act.

204. The rent due must be certain. 205. The notice to quit.

206. By whom notice can be given.

207. To whom notice should be given and manner of service.

208. Payment of rent on removal.

\section{SECTION}

209. The complaint.

210. Summons.

$2 i \dot{i}$. The service of the summons.

212. The hearing.

2r3. The neeessary proof.

2I4. The judgment.

215. A ppeal.

2I6. Certiorari.

2r7. The execution.

2I8. Appeal to Supreme Court.

The Act of 1830 .

202. "In case any lessee for a term of years, or at will, or otherwise, of a messuage, lands or tenements upon the demise whereof any rents are, or shall be reserved, shall neglect or refuse to pay rent reserved as often as the same may grow due according to the terms of the contract, and where there are no goods on the premises adequate to pay the said rent so in arrear, except such articles as are exempt from levy and sale by the laws of this commonwealth, it shall and may be lawful for the lessor to give the lessee notice to quit the premises within fifteen days from the date of the notice, if such notice is given on or after the Ist of April and before the Ist of September, and within thirty days from the date thereof if given on or after the Ist of September and before the Ist day of April; and if the lessee shall not within the period aforesaid, remove from and deliver up the said premises to the 
said lessor or pay and satisfy the rent so due and in arrear, it shall be lawful for the lessor to make complaint on oath or affirmation to any two aldermen or justices of the peace, as the case may require, who, on its appearing to them that the lessor has demised the premises for a term of years or otherwise, whereof any rent or rents have been reserved, that the said rent is in arrear and unpaid, that there is not sufficient goods and chattels on the premises to pay and satisfy the said rent, except such as are by law exempt from levy and sale, and that the lessee has, after being notified in manner aforesaid, refused to remove and re-deliver up possession of the premises, shall then and in that case insure their precept, reciting substantially the complaint and allegation of the lessor, directed to any constable of the proper city or county, commanding him to summon the said lessee to appear before the said alderman or justices at a day and time to be therein fixed, not less than three nor more than eight days thereafter, to answer the said complaint, and the said alderman or justices shall, on the day appointed, or on some other day then to be appointed by said justices or aldermen, proceed to hear the case, and if it shall appear that the said complaint, so made as aforesaid by the lessor, is in all particulars just and true, then the said aldermen or justices shall enter judgment against such lessee that the premises shall be delivered up to the lessor, and at the request of the lessor issue a writ of possession directed to the said constable, commanding him forthwith to deliver actual possession of the premises to the lessor and also to levy costs on the defendant in the same manner that costs are now by law levied and collected on other writs of execution; but if on the hearing aforesaid it shall appear that the said complaint is vexatious and unfounded, the said alderman or justices shall dismiss the same, with costs to be paid by the lessor. Provided always, that at any time before the said writ of possession is actually executed, the lessee may supersede and render the said writ of none effect, by paying to the said constable for the use of the 
lessor the rent actually due and in arrear and the costs; which rent so in arrear shall be ascertained and determined by the said aldermen or justices on due and legal proof and endorsed by them on the said writ of possession, together with the costs of the proceedings, of all which doings the said constable shall make return to the said aldermen or justices within ten days after receiving of the said writ, and the said constable shall be answerable in default of executing the said writ according to its lawful requisitions or in returning the same in the same manner as to the amount of rent, ascertained and determined and costs as constables are now by law answerable on other writs of execution.' And provided further, that no writ of possession shall be issued by the said aldermen or justices for five days after the rendition of judgment, and if within the said five days, the tenant shall give good, sufficient and absolute security by recognizance for all costs that may have and may accrue, in case the judgment shall be affirmed, and also for all rent that has accrued, or may accrue up to the time of final judgment, then the tenant shall be entitled to an appeal to the next court of common pleas, which appeal shall be then tried in the same manner that other suits are tried. And provided further, that nothing herein contained shall prevent the issuing a certiorari with the usual form and effect." 1

\section{Who May Have the Benefit of the Act.}

203. Lessors are expressly given the benefit of the law. The word lessor seems to mean the same as landlord, and consequently heirs, grantees and devisees of the original lessor would have the benefit.

\section{The Rent Due Must be Certain.}

204. The tenant has the privilege to stop the proceedings by the payment of his rent, and as the amount of rent due 
must be found in the proceedings, there is an indication that the rent must be certain as under the acts of 1772 and 1863 , and in proceedings for distraint for rent.

\section{The Notice to Quit.}

205. By the notice there must be a demand for the rent claimed. The rent must not be calculated to a date subsequent to that of the notice. ${ }^{1 *}$

\section{By Whom Notice Can be Given.}

206. The act of 1830 provides that the lessor shall give the notice, but an heir can do so and avail himself of the remedy.? and also a sheriff's vendee and an assignee. ${ }^{3}$

\section{To Whom the Notice Should be Given and Manner of Service.}

207. In case the tenant has not assigned his lease or underlet the demised premises the notice may be served on the defendant on the premises or elsewhere. ${ }^{3}{ }^{*}$ In case the tenant has assigned or underlet, the notice must be served upon the individual residing on the premises, viz., the assignee or under-tenant. A sub-tenant cannot be turned out of possession without notice, for he may be willing to pay the rent. It seems that it will be best to give notice to the lessor as well as the assignee and under-tenants, and that if any person is entitled to notice he can be served on or away from the premises. $^{4}$ In case a person entitled to notice cannot be found it may possibly be sufficient to leave the notice at his residence or on the premises, but a personal service should be made if possible. For further remarks as to service, see as to notice under act of 1863 .

I* Stoever $v$. Miller, 4 Phila. I 49.

2 Clark v. Everly, 8 W. \& S. 226.

3 McKeon v. King, 9 Barr. 213; Glenn v. Thompson, 75 Pa. 389.

$3^{*}$ Reid v. Christy, 2 Phila. Rep. I44.

4 Clark v. Everly, 8 W. \& S. 226. 
Payment of Rent on Removal.

208. The tenant can pay the rent and thereupon the proceeding will be stayed, or he may remove, but, in case of a removal, the tenant should notify the landlord.

\section{The Complaint.}

209. If the lessee shall not remove from and deliver up the premises to the lessor, or pay and satisfy the rent due and in arrear, the lessor can make complaint on oath or affirmation to an aldernan, a justice of the peace or magistrate. The complaint must show that the lessor has demised the premises for a term of years or otherwise, and that certain rent has been reserved; that the rent is in arrear and unpaid; that there are not sufficient goods and chattels on the premises to pay and satisfy the rent in arrear, except such as are by law exempted from levy and sale, and that the lessee has, after being notified as aforesaid, refused to remove and deliver up possession of the premises. If the lessor has conveyed or has died intestate or has devised the demised premises, there should be averments accordingly.

\section{Summons.}

210. The precept recites substantially the complaint and allegation of the lessor. It is directed to any constable of the proper city or county, commanding him to summon the lessee to appear before the alderman, justice or magistrate, at a day and time to be therein fixed, not less than three nor more than eight days thereafter, to answer the said complaint.

The Service of the Summons.

2II. The law does not state the manner of service. It probably can be served the same as a summons in an ordinary suit. The act of 1830 , like the act of 1772 , does not prescribe the manner of service. It was remarked that under the act of 1772 for possession, the summons could be served on an agent at a theatre because at the time of the passage of the act personal service of the ordinary summons was not 
necessary, ${ }^{5}$ but it was said from the language of the act, service on the demised premises upon the person in possession seems to be contemplated. In Snyder $v$. Carfrey, $54 \mathrm{~Pa} .94$, it was held that a return as served "personally on the defendant at his dwelling-house by leaving a copy of the original summons and making known the contents thereof," was good under the act of 1863 , and of any summons. ${ }^{6}$

\section{The Hearing.}

212. The aldermen or justices on the day appointed, or on some other day then to be appointed, proceed to hear the case, and if it shall appear that the complaint is in all particulars just and true, then the said aldermen or justices enter judgment against the lessee that the demised premises shall be delivered up to the lessor. At the hearing the lessor must prove the allegations in his complaint. If the lease is in writing, it should be produced and proved in the legal way. Under our present law, the lessor, if his tenant be living, can be a witness. The notice to quit should be proved by the person who served the notice. The jurisdiction of the justice or alderman and of the court of common pleas on appeal, will be ousted where it shall appear by the evidence that a question of title arises between the party charged as tenant and the party claiming as landlord; for instance, where the lessee should claim to have the lessor's title by parol purchase from him, the lessee is entitled to have his rights determined in an action of ejectment. The tenant has no right to attorn to the holder of an adverse title. The title of a stranger, not claiming by or under the lessor, cannot come in question unless the title of the lessor has actually come to an end by his own act, or been divested by act of the law. The lessee can prove that the lessor's title, having expired, has become vested in another. It is not necessary that the evidence must fully establish the invalidity. A lessor entered into a parol

5 Watts v. Fox, 64 Pa. 336. 6 Snyder v. Carirey, 54 Pa. 94. 
agreement for the sale of premises; the lessee, from the date of the agreement, for several years had exclusive possession of the premises under it; the parties had, during all that time, treated the lease as at an end, and a large number of payments had been applied on account of the purchasemoney. It was held that the lessee was entitled to have his rights determined by an action of ejectment. ${ }^{i}$

\section{The Necessary Proof.}

2I3. Under the act of I830, the landlord must prove the demise; the reservation of rent; the tenant's failure to pay the same; the insufficiency of the goods on the premises, not exempt from levy and sale, to answer a distress; the service of proper notice to quit, and the tenant's failure to pay the rent in arrears, or to remove from the premises before the inception of the proceedings. ${ }^{8}$

\section{The Judgment.}

214. The judgment must be against the lessee; that the premises shall be delivered up to the lessor, it cannot be for the rent in arrear; it should not be in the alternative for the rent or possession. An execution cannot be issued for the rent under the judgment. However, the rent in arrear must be ascertained and determined by the justice or alderman, on due and legal proof, so that the same can be endorsed by him on a writ of possession. If, on the hearing, the complaint shall be found to be vexatious and unfounded, it will be dismissed and the costs will be ordered to be paid by the lessor.

\section{Appeal.}

215. No writ of possession shall be issued for five days after the rendition of the judgment: and if within the five days the tenant shall give good, sufficient and absolute security, by recognizance, for all costs that may have, and may ac-

7 Mohan $v$. Butler, rr2 Pa. 590.

8 Palethorp $v$. Schmidt, I2 Super. Ct. R. 214. 
crue, in case the judgment shall be affirmed, and also for all rent that has accrued or may accrue up to the time of final judgment, then the tenant shall be entitled to an appeal to the next court of common pleas, which appeal shall be then tried in the same manner in which other suits are tried. The act does not expressly say that the appeal will be a supersedeas of execution, but it seems to be the intention that it shall be. Upon an appeal the case is tried upon the merits, as if no decision had been made before. If the proceedings are affirmed by the court of common pleas, a writ of possession can be issued.

\section{Certiorari.}

2I6. The act provides that a certiorari can be issued with the usual form and effect. In the state, except in the city of Philadelphia, the certiorari can be issued within twenty days after the date of the judgment or the tenant's knowledge of the judgment. The certiorari, however, in the state, outside Philadelphia, will not be a supersedeas of execution. Upor proceedings upon certiorari the court will not consider the testimony or evidence; the only questions involved will be those concerning the regularity of the proceedings. In case of a charge of fraud, or where there is a question of jurisdiction, depositions may be taken for the hearing on the certiorari. In a certiorari to the judgment of a magistrate in a proceeding by a landlord under the act of 1830 to recover possession of premises for non-payment of rent it is sufficient if the transcript of the record of the magistrate discloses the facts necessary to give jurisdiction. It is not necessary that all of the facts should be set forth in detail; the general finding was in the very words of the statute, and was sufficient. ${ }^{9}$ In the city of Philadelphia the certiorari will be a supersedeas of execution until the final determination by the court, provided it shall be issued within ten days from the date of the judgment, 
and upon oath of the party applying for the same (to be administered by the prothonotary of the court of common pleas), that the certiorari is not for the purpose of delay, but that the proceedings proposed to be removed are, to the best of his knowledge and belief unjust and illegal, and will oblige him to pay more money than is justly due, a copy of which affidavit shall be filed in the prothonotary's office, and the party applying for the certiorari shall give security for the payment of all costs that have accrued or may accrue, and of the rent which has already or may become due up to the time of the final determination of the certiorari, in the event of the same being determined against him. ${ }^{10}$

\section{Tne Execution.}

217. If no appeal shall be taken or no certiorari issued, in the city of Philadelphia, a writ of possession will be issued, directed to a constable, commanding him forthwith to deliver actual posession of the premises to the lessor, and also to levy the costs on the defendant in the same manner in which costs are levied and collected on other writs of execution, provided that at any time before the writ of possession is actually executed, the lessee may supersede and render the writ of none effect by paying to the constable. for the use of the lessor, the rent actually due and in arrear, and the costs; which rent in arrear is to be found and endorsed on the writ of possession with the costs as aforesaid. The constable must make return of the writ of possession within ten days after receiving the writ.

\section{Appeal to Supreme Court.}

218. If, upon appeal to the court of common pleas by a tenant, the judgment is affirmed against him, he may appeal to the Superior Court or Supreme Court, as the case may be, in which case the testimony taken in the court of common pleas will be considered.

10 Act March 24, 1865, I P. \& L. Dig. 2559; P. L. 750. 
CHAPTER VIII.

PROCEEDINGS TO OBTAIN SECURITY EOR RENT OR POSSESSION WHEN TENANT REMOVES FROM THE DEMISED

PREMISES, IN PHILADELPHIA.

SECTION

219. Act of March 25, 1825 .

220. Tenant must remove.

22I. Notice must be signed by landlord or his agent.
SECTION

222. Complaint must show a lease for years.

223. Tender of rent.

Act of March 25, 1825.

219. "If any lessee for a term of years in the city and county aforesaid, shall remove from such demised premises, without leaving sufficient property thereon to secure the payment of at least three months' rent, or shall refuse to give security for the payment thereof, in five days after demand of the same, and shall refuse to deliver up possession of such premises, it shall and may be lawful for the landlord or lessor to apply to any two aldermen or justices of the peace within the city and county of Philadelphia, and make an affidavit or affirmation of the fact, and thereupon the said aldermen or justices of the peace shall forthwith issue their precepts, to any constable of the proper city or county, commanding him to summon such lessee, before such aldermen or justices, on a day certain, not exceeding eight nor less than five days, to answer such complaint. And the said aldermen or justices shall, on the day appointed, proceed to hear the case, and, if it shall appear that the lessee has removed from the premises, without leaving sufficient goods and chattels, or giving security for the payment of the rent as aforesaid, and has refused to deliver up possession of the demised premises, they 
shall enter judgment against such lessee, that said premises shall be delivered up to the lessor or landlord forthwith, and shall, at the request of the said lessor or landlord, issue a writ of possession, directed to said constable, commanding him forthwith to deliver possession of the premises to the landlord or lessor and also to levy the costs on the defendant, in the same manner that executions issued by justices of the peace are directed by law." 1

\section{Tenant Must Remove.}

220. On May 20, I826, a landlord notified a tenant to give security for three months' rent in five days or to give peaceable possession on or before May 26. The tenant did not comply. On May 27, the landlord made an affidavit before two justices of the peace that the tenant then had possession as tenant from year to year of a certain house, that he had no goods or personal property on the premises, sufficient to satisfy a quarter's rent; but that nearly all had been removed; that he had demanded the security or possession. On the same day the summons was issued judgment was rendered against the tenant, a writ of possession was issued. A writ of certiorari was afterwards issued by the court of common pleas and on a hearing the judgment was reversed. On a writ of error to the court of common pleas the Supreme Court held that it is not sufficient that the tenant has removed part of his goods without leaving sufficient to secure the payment of three months' rent while he himself remains in possession of the premises. ${ }^{2}$

\section{Notice Must be Signed by Landlord or His Agent.}

221. A notice under the act was signed by George W. Powell, not as agent or attorney of the landlord nor in his own right as assignee or purchaser, although he subsequently claimed to act as the agent of the landlord. The tenant was

I Act March 25, 1825, P. \& L. Dig. 2659.

2 Fretag $v$. Anderson, I Rawle, 72. 
not served personally with the notice or summons and he did not waive or cure the defect by an appearance. The judgment of the justices was reversed and the proceedings were quashed. ${ }^{3}$

\section{Complaint Must Show a Lease for Years.}

222. The complaint must allege that the premises were let by plaintiff to defendant for a term of years."

\section{Tender of Rent.}

223. A sub-tenant is entitled to the right of tendering security for rent under the act. ${ }^{5}$ A tender after the five days is too late. ${ }^{6}$

3 Powell v. Campbell, 2 Phila. 42.

4 Geisènberger $v$. Cerf, I Phila. I7; Mund $v$. Vanfleet, 2 Phila. 4 I.

5 Grider $v$. McIntyre, 6 Phila. II2.

6 IVard $v$. Wandell, ro $\mathrm{Pa} .98$. 


\section{CHAPTER IX.}

\section{COLLECTING RENTS.}

SECTION

224. Jurisdiction of justices of the peace, etc.

225. The hearing.

226. Suits in court.

227. Practice in equity as to receivers collecting rents.

228. Collection of rent due during administration of receivers.

229. Loss of rents collected by receiver from sub-tenants.

230. Recovery of rent in case of death of tenant.

23I. Landlord to present claim to the orphans' court.

232. Collection of rent in case of bankruptcy.

233. Rent under the bankrupt act of 1898 not apportioned.

Rights to Rent from Sheriff's Sales of Personal PropERTY.

234. Act of 1836 .

235. Rent apportioned.

236. Landlord should notify sheriff of his claim.
SECTION

237. Note taken no waiver of claim.

238. The goods must have beer liable to distraint.

Equitable Relief to a Tenant IN CASE RENT IS Claimed by Two Adverse Parties

239. The nature of the proceeding.

Preference of Wages over RENT.

240. Act of April 9, 1872.

24I. The claim for wages may be sold and assigned.

Collection of Rent by AtTACHMENT.

242. Liability of rent due to be attached by an attachmentexecution.

243. Iiability of tenant in case of foreign attachment against the landlord.

Jurisdiction of Justices of the Peace, etc.

224. Justices of the peace and magistrates have origina? jurisdiction of all cases of rent not exceeding $\$ 100$ to be recovered as debts of similar amounts are recoverable. ${ }^{1}$ The

I Act March 22, I8I4, I P. \& L. Dig. 2550, § 43; 6 Sm. L. I82. 
jurisdiction of justices of the peace in cases of contract, etc., is given where the sum demanded does not exceed $\$ 300$, but this extension does not apply to magistrates in cities of the first class. ${ }^{2}$

\section{The Hearing.}

225. At the hearing the landlord proves the renting and the rent in arrear. If there is a lease it should be produced and proved if not admitted. The parties can appeal from the judgment of the justice as in other cases and there can be a certiorari and the proceedings are as in other cases.

\section{Suits in Court.}

226. If the amount of the claim is sufficient the tenant can be summoned to appear in court and the case proceeds as in other cases. In case of a judgment and execution the constable or sheriff, as the case may be, should be notified if the tenant has waived the exemption law.

\section{Practice in Equity as to Receivers Collecting Rents.}

227. "When a receiver is appointed to take charge of real estate, tenants are ordered to attorn to him and to pay him the rents. .. . Tenants can be requested to attorn and be served with a copy of the order. If they refuse, a petition can be presented setting forth the facts and notifying the tenants that application will be made to the court at the time named. The court then makes the order to attorn and it is enforced by attachment. . . The rights of a landlord are not affected by the appointment of a receiver, but the landlord cannot exercise his rights without leave of the court. When the receiver sold the goods of a tenant without distraining, the English courts gave no priority to the landlord." 3

2 Act July 7, I879; I P. \& L. Dig. 2553, § 51; P. L. 194, § 1.

3 Brewster's Practice (Equity), § 6136. 
Collection of Rent Due During Administration of Receivers.

228. A landlord has a lien on the fund raised by sale by a receiver which had accrued under the receivership and the fund should not be reduced by commissions or counsel fees, but the landlord may be charged with part of the costs of an audit, if necessary to adjudicate conflicting claims. ${ }^{4}$

\section{Loss of Rents Collected by Receiver from Sub-Tenants.}

229. If receiver collects rents from sub-tenants, the landlord should receive the entire amount collected unless mingled in a general fund in conducting business and the landlord takes no steps to have the court direct such rental set apart. If the landlord fails to do this he will lose his priority for such rents. ${ }^{5}$

\section{Recovery of Rent in Case of Death of Tenant.}

230. By the act of Feb. 24, I834, the debts of a decedent are to be paid as follows:

I. Funeral expenses, medicine furnished and medical attendance given during the last illness of the decedent, and servants' wages not exceeding one year.

II. Rents not exceeding one year.

III. All of the debts, without regard to the quality of the same, except debts due to the commonwealth, which shall be last paid.

While the first class ought, where the estate is certainly solvent, to be paid immediately, the claim for rent is not required to be paid until the expiration of a year after letters granted. ${ }^{6}$ The landlord of the deceased insolvent tenant is not entitled to the preference to a year's rent which did not accrue until the death of the tenant. ${ }^{7}$

4 Lane v. Hotel Co., I90 Pa. 230.

5 Lane v. Hotel Co., I90 Pa. 230.

6 Hood on Executors, 176.

7 McKim's Est., 2 Clarke, 224. 
Iandlord to Present Claim to the Orphans' Court.

231. After the death of a tenant it would seem that resort must be made to the remedy provided by the said act of assembly, and that the right to distrain for the rent is gone. ${ }^{8}$

\section{Collection of Rent in Case of Bankruptcy.}

232. On Nov. 25,1898 , a petition in bankruptcy was filed. On Nov. 28, I898, a distress was made for rent due Nov. I. On Dec. 2, 1898, a distress was made for another month's rent. On Dec. I2, I898, the bankrupt court made an order that the landlords should proceed no further with the distress, but should deliver to the receiver the property distrained upon, subject to whatever lien, if any, there might be for said rent and costs which should be paid as a preferred claim out of the first moneys in the hands of the receiver. The trustee was ordered to pay the rent and for use and occupation. The referee said that "Where the landlord makes a demand upon the assignee before the removal of the goods for an amount not exceeding a year's rent, it should, I think. if unpaid, be admitted as entitled to priority of payment, whether the right of distraint exists or not. Where more than a year's rent is demanded, the question of the right of distraining will arise." The court (McPherson, J.) overruled exceptions to the allowances. ${ }^{9}$

\section{Rent under the Bankrupt Act of 1898 Not Apportioned.}

233. The former bankrupt law provided for an apportionment and payment of rent up to the time of the bankruptcy: The present law has no such provision. It has been held that rent to accrue in the future cannot be called a debt owing. Only those instalments of rent which have become due and payable before the filing of the petition are provable. "No matter how large a portion of the instalment period has transpired, unless it has been fully completed, and the instalment

8 Hoskins $v$. Housten, 2 Clarke, 489.

9 In re Gerson, $8 \mathrm{~Pa}$. Dis. R. 277. 
of rent has become due, there is no provable claim. The lessor's rights against the bankrupt are unaffected, but he can collect payment from after-acquired property only. He cannot share in the assets administered in bankruptcy." 10 It is suggested that there can be a clause in a lease providing that in case any petition shall be signed or presented, to have the lessee or his assignee of the lease adjudged a voluntary or an involuntary bankrupt under the bankrupt law of the United States, that then the rent of the current period shall be apportioned to the date of such signing and the apportioned amount due at that time shall be paid as a debt due in bankruptcy.

RIGHTS TO RENT FROM SHERIFF'S SALE OF PERSONAL Act of 1836. PROPERTY.

234. When goods liable to the distress of the landlord are sold upon execution, the landlord is entitled to an amount not exceeding one year's rent from the proceeds of sale. ${ }^{11}$

Rent Apportioned.

235. Rent, although not then due, will be apportioned to the time of the levy. ${ }^{12}$

Landlord Should Notify Sheriff of His Claim.

236. The landlord should give notice of his claim to the sheriff before the sheriff has parted with the proceeds; and the sheriff should give reasonable time for such claim to be made. ${ }^{13}$

Note Taken no Waiver of Claim.

237. The landlord can make his claim, although a note has been taken for the rent. ${ }^{14}$

Io Collier on Bankruptcy, 349. II Act June I6, I836.

12 Wickey $v$. Eyster, $58 \mathrm{~Pa}$. 501. 13 Fisher $v$. Allen, 2 Phila. 115.

14 Kendig v. Kendig, 3 Pitts. Rep. 287. 
The Goods Must Have Been Liable to Distraint.

238. A landlord cannot claim rent in arrear out of the proceeds of a sheriff's sale of a tenant's goods which were not, at the time of the levy, upon the demised premises, and liable to distraint. ${ }^{15}$

\section{EQUITABLE RELIEF TO A TENANT IN CASE RENT IS CLAIMED BY TWO ADVERSE PARTIES.}

\section{The Nature of the Proceeding.}

239. A tenant filed a bill in equity stating that she was the tenant of certain premises, and was subjected to conflicting claims for the rent due by her, in consequence of the action of the landlord. Against these double claims she asked to be protected. It was held that in the case of a claim under a title paramount and hostile to the landlord the relief would not be granted; but as the landlord himself had subjected a tenant to a double liability, the prayer of the bill was granted and the accruing rent was ordered to be paid to a receiver. In cases of this sort the tenant does not dispute the title of his landlord, but he affirms the title, and the tenure and contract by which the rent is payable, and puts himself upon the mere uncertainty of the person who is to pay the rent. ${ }^{16}$ Sometimes difficulties arise from the conveyances of the landlord, or between his heirs and devisees, and in such case relief to a tenant will be granted.

\section{PREFERENCE OF WAGES OVER RENT.}

Act of April 9, 1872.

240. Under the act of April 9, 1872, and its supplement of June 12,1878 , the claims of mechanics, laborers and others employed in and about mines, manufactories or other business, are preferred to claims for rent of any of said mines, 
manutactories, or other real estate held under lease, where the lessee or lessees are the parties employing the mechanics, laborers and others.

The Claim for Wages May be Sold and Assigned.

24I. The claim for wages may be sold and assigned. ${ }^{1-}$

\section{COLLECTION OF RENT BY ATTACHMENT.}

Liability of Rent Due to be Attached by an Attachment-Execution.

242. Upon a plaintiff obtaining a judgment against a defendant he can obtain what is known as an attachment-execution. Upon the writ of attachment being served on the tenant of the defendant, debts due by the tenant are attached. Money coming into the hands of a garnishee after the service of an attachment-execution and before it is dissolved is bound thereby. ${ }^{18}$ E. owned land which was leased, he applied to be discharged as a bankrupt December 7 , and was discharged December I2. A quarter's rent fell due the I 5 th of the next January passed to the assignee, and no part of it was bound by an attachment-execution served November $2 \mathrm{I}$. Held, that in foreign attachment the land itself can be attached and a lien which carries with it the accruing rents obtained, but an attachment-execution cannot be levied of land, but only of debts or choses in action. Rent not due is an incident of the reversion, is a part of it, and therefore, a part of the realty, and a levy on the reversion which the plaintiff might make on a $f$. $f a$. would have fastened on the rent and carried it over by a sale to the purchaser of the reversion. ${ }^{19}$

Liability of Tenant in Case of Foreign Attachment Against the Landlord.

243. The landlord's title may be attached by a foreign attachment. That is, a non-resident of Pennsylvania may own

17 Riddlesburg C. \& I. Co.'s Ap., II4 Pa. 58.

18 Mahon v. Kunkle, 50 Pa. 216. I9 Evans v. Hamrick, 6I Pa. I9. 
real estate in that state and suit may be commenced against him to compel his appearance in the suit. Upon real estate being attached a copy of the writ is served upon the tenant, which has the effect of sequestering in the hands of the tenant all rent due and which will fall due until the execution against the garnishee, unless the attachment is sooner dissolved. The court may, at any time after the return of the attachment, on application by the plaintiff, and affidavit of a just cause of action, issue a writ to the sheriff, requiring him to collect and recover from the tenant of the premises all such rent due or as may accrue after the attachment until further order of court. No such order, can, however, be made, unless the sheriff return that the tenant holds under the defendant in the attachment. The sheriff has the same power as any landlord, and when he collects the rent he pays it into court. A third party cannot be permitted to take the money out of court without a notice to the tenant by a scire facias. After judgment against the tenant as garnishee, the plaintiff can have execution for the rents attached in the tenant's hands, in case the sheriff has not collected the same; but in case the sheriff shall have collected the rents, then, upon an award of execution against the tenant, the plaintiff in the attachment suit may have the money in court paid into his hands, on his giving security to restore. In case the rents are not sufficient to pay the judgment, the real estate is sold at sheriff's sale as in other cases. ${ }^{20}$

20 Act June 13, 1836, I P. \& L. Dig. 2161, 2162, 2163, 2164; P. L. 568. 


\section{CHAPTER X.}

\section{DISTRAINT FOR RENT.}

PAge IOI.

SECTION

244. Act of March 21, 1772, regulating distraints for rent.

245. Distraint after termination of lease.

246. Distraint by lessor who has conveyed.

247. Distraint by executors and administrators.

248. Distraint by an assignee of the reversion.

249. Distraint by joint tenants.

250. Distraint by tenants in common.

251. Distraint by guardians.

252. Distraint by receivers.

253. Distraint by heirs, devisees, etc.

254. What rent may be distrained for.

255. Goods liable to distress.

256. Goods privileged from distress.

257. Authority given to distrain.

258. Penalty for distraining when no rent is due.

259. Distraining for morc rent than is due.

260. Entering premises to make a distraint.

261. Distraining upon the goods.

262. Rescue of goods distrained.

263. Interference with distraint proceedings.
sEctIoN

264. Unreasonable or excessive distraint.

265. Placing watchman.

266. Leaving goods on premises.

267. Notice, etc., to tenant.

268. Tender of rent.

269. Replevin.

270. The time for issuing the writ.

27r. Order for the writ.

272. Entering security.

273. The pleadings.

274. Trial and judgment.

275. Replevin the proper remedy for illegal distraint upon stranger's goods.

276. Liability of landlord for distraining on goods of a stranger.

277. Appraisement of the goods.

278. Sale of goods.

279. Manner of sale.

280. Exemption of rented pianos.

281. Exemption of sewing machines.

282. Liability of goods sold according to instailment plan.

283. Three hundred dollars exemption law.

284. Appraisers to be appointed.

285. Under-tenants cannot claim benefit.

286. Refusal of exemption.

287. Who can claim exemption. 
SECTION

288. When claim should be made.

289. Request for appraisement.

290. How claim is to be made when tenant absent.

291. Right to distrain on property fraudulently removed under act of 1772 .
SECTION

292. Goods of a stranger not to be followed.

293. Goods sold are exempt.

294. Rent must. be due at time of removal.

295. Right to collect rent not due under act of 1825 .

\section{Act of March 21, 1772, Regulating Distraints for Rent.}

244. The act provides that, "When any goods or chattels shall be distrained for any rent reserved and due, upon any demise, lease or contract whatsoever, and the tenant or owner of the goods so distrained shall not, within five days next after such distress taken, and notice thereof, with the cause of such taking, left at the mansion-house or other most notorious place on the premises, charged with the rent distrained for replevy the same with sufficient security according to law; then, and in such case, after such distress and notice as aforesaid, and expiration of said five days, the person distraining shall and may, with the sheriff, under-sheriff or any constable in the city or county, where such. distress shall be taken (who are hereby required to be aiding and assisting therein), cause the goods and chattels so distrained to be appraised by two reputable freeholders, who shall have and receive for their trouble the sum of two shillings per diem each, and shall first take the following oath or affirmation: I, A. B., will well and truly, according to the best of my understanding, appraise the goods and chattels of C. D., distrained on for rent by E. F.; which oath or affirmation such sheriff, under-sheriff or constable are hereby empowered and required to administer; and, after such appraisement, shall or may after six days' public notice lawfully sell the goods and chattels so distrained for, for the best price that can be gotten for the same, for and towards satisfaction of the rent for which the said goods and chattels shall be distrained, and of the charges of such distress, appraisement and sale, leaving the 
overplus, if any, in the hands of the said sheriff, under-sheriff or constable for the owner's use." 1

Distraint After Termination of Lease.

245. By the act of March 21, I772, a landlord may distrain for arrears of rent after the termination of the lease, provided his title or interest continues.

Distraint by Lessor who has Conveyed.

246. A lessor who has conveyed has no right to distrain for rent in arrear. ${ }^{1 *}$

Distraint by Executors and Administrators.

247. Executors or administrators can distrain for arrearages of rent due to a decedent at the time of his decease.

Distraint by an Assignee of the Reversion.

248. When a lessor assigns his reversion, the assignee may distrain under the statute of 32 Henry VIII, in force in this state. When a landlord conveys, it will be best to take an assignment of the lease to the purchaser.

\section{Distraint by Joint Tenants.}

249. One of several joint tenants may distrain for the whole rent, although he must avow jointly with his companions.

\section{Distraint by Tenants in Common.}

250. Tenants in common not holding one title, and possessing several estates, must distrain severally for the respective portions, and avow separately. In case tenants in common make a joint lease, they may distrain together.

Distraint by Guardians.

25I. Guardians may distrain for rent due their wards.

\section{Distraint by Receivers.}

252. A receiver in chancery may distrain without any special order of court, but if there is a doubt in whom the 
legal right exists, he should get an order, as he must distrain in the name of the person having the legal right.

Distraint by Heirs, Devisees, etc.

253. Heirs and devisees and trustees imposed with the duty of collecting rent may distrain.

What Rent may be Distrained For.

254. The rent must be certain, or that which can be made certain. On a demise of a grist-mill, the lessee to render one-third of the toll, the lessor may distrain for a certain quantity of grain the value being stated. ${ }^{2}$ Rent payable in kind by a share of grain may be distrained. ${ }^{3}$ When the rent is a certain quantity of grain the lessor may distrain for so many bushels in arrear and name the value, in order that if the goods should be replevied or the arrears tendered, the officer may know what amount of money is to be raised by the sale and in such case the tenant may tender the arrears in grain. ${ }^{4}$ In case of a lease of a farm on shares the lessor can distrain as in the case of a money rent. ${ }^{5}$ A lease was for a fixed rent in money, and at the additional rent of $\$ 30$ per annum for every sum of $\$ 500$ or fractional part thereof that should be expended in permanent improvements made by the landlord. Held, that the $\$ 30$ additional rent could be distrained for. ${ }^{6}$ If lessee covenants to pay lessor for all gas consumed on the premises, a sum for gas consumed is to be regarded as rent in arrear, and may be distrained for. ${ }^{7}$

\section{Goods Liable to Distress.}

255. The goods of a stranger whilst on the premises. ${ }^{8}$ The goods of a sub-tenant. ${ }^{9}$ Household furniture furnished a

2 Fry $r$. Jones, 2 Rawle, $11 . \quad 3$ Steel $v$. Frick, 56 Pa. 172.

4 Warren $v$. Forney, I3 S. \& R. 52.

5 Brown $\tau$. Jacquette, $94 \mathrm{~Pa}$. II3.

6 Detwiler v. Cox, 75 Pa. 200. 7 Assn. v. Jones, I02 Pa. 307.

8 Karns v. McKinney, $74 \mathrm{~Pa} .387$.

9 Page $v$. Middleton, $118 \mathrm{~Pa} .546$. 
boarding-house keeper for use in her boarding-house. ${ }^{10}$ The goods of a person conducting an independent business. ${ }^{11}$ Fixtures slightly attached to the premises which the tenant may remove at his pleasure. ${ }^{12}$ Goods on storage not with a warehouseman. ${ }^{13}$ The goods of a mere renter of rooms. ${ }^{14}$ All furniture not in the actual use of the boarder, necessary for his boarding and lodging in the house. ${ }^{15}$ By the act of March 21, 1872, any cattle or stock of tenants feeding or depasturing upon the demised premises; all sorts of corn, grass, hops, roots, fruits, pulse or other produce whatsoever, which shall be growing upon the demised premises, may be distrained for rent, and the purchaser shall have free ingress and regress to and from the same where growing, to repair the fences from time to time, and when ripe, to cut, gather, make; cure and lay up and thresh, and after to carry the same away in the same manner as the tenant might have done, had such distress never been made. Goods levied upon, claimed by a third party after an interpleader narr and bond filed. ${ }^{16} \mathrm{~A}$ brick malt-house erected by a tenant and which he could remove. ${ }^{17}$

Goods Privileged from Distress.

256. Implements of trade if they be in actual use at the time or if there be any other sufficient distress on the premises. Things annexed to the freehold which the tenant cannot legally remove. Things delivered to a person exercising a public trade, to be carried, wrought, worked up or managed in the way of his trade or employ. Goods which cannot be restored again in the same plight and condition.

so Myers c. Esery, $3.34 \mathrm{~Pa} .177$.

II Karns $v$. McKinney, $74 \mathrm{~Pa} .387$.

I2 Furbush $\%$. Chappel, I05 $\mathrm{Pa} .187$.

13 Page $v$. Middleton, II $8 \mathrm{~Pa} .546$.

14 Lane $\%$. Steinmetz, 9 W. N. C. 574.

I5 Jones $v$. Goldbeck, 8 W. N. C. 532.

16 Gillian $v$. Tobias, 2 W. N. C. 37 I.

I7 Spencer v. Darlington, 74 Pa. 286. 
Goods in the custody of the law. ${ }^{18}$ Where the tenant in the course of his business is necessarily put in possession of the property of those with whom he deals, or of those who employ him, such property is not liable to distress for rent: for example, goods on storage, the goods of a guest at a hotel, the goods of a boarder for rent due by a boarding-house keeper, grain sent to a mill, cloth in a tailor's shop, goods on a wharf, goods of a principal in the hands of a factor. ${ }^{19}$

\section{Authority Given to Distrain.}

257. Thelandlord may himself distrain without theintervention of a constable; but a constable will be required when the inventory and appraisement shall be made thereafter. It will be best, however, to have a constable to attend to the matter from the beginning, so that one may have the benefit of his knowledge and experience. It is customary to give a constable a warrant authorizing him to distrain. A correct bill or statement for the rent due should be given to him. The constable will obtain the necessary information from the landlord and make out the warrant. A landlord issuing a warrant for distress is required to credit on the rent in arrear only. actual payments and such sums as the parties have agreed to treat as payments on account of rent. $\mathrm{He}$ is under no legal obligation to deduct any claim for unliquidated damages which the tenant may have against him. ${ }^{20}$ In distraining for rent interest should not be added to the rent. ${ }^{21}$

\section{Penalty for Distraining when no Rent is Due.}

258. By $\S 3$ of the act of March 2I, I772, double the value of the goods distrained and sold with costs may be recovered. It has been held that the injured party may elect to bring an action at common law, and, if the circumstances warrant,

18 Simpson $v$. Hartopp, and notes, vol. I, part II, 8th ed., Smith's Leading Cases, 783, 450.*

19 Karns v. McKinney, $74 \mathrm{~Pa} .387$.

20 Speneer $v$. Clinefelter, IOr $\mathrm{Pa} .219$.

21 Bantleon v. Smith, 2 Binney 145. 
recover exemplary damages exceeding the amount of the statutory penalty. ${ }^{22}$ Making the distress, when the claim is wholly false, is a mere trespass. ${ }^{23}$

Distraining for more Rent than is Due.

259. When the landlord distrains for more rent than is due or makes an excessive distress he is liable in an action. ${ }^{24}$

\section{Entering Premises to Make a Distraint.}

260. A landlord may not break open an outer door to make a distraint, nor may he break open or tear down gates or enclosures for that purpose. He may enter an open door or window. He may break open inner doors. If he has entered and made a distraint and is refused admittance afterward, for the purpose of proceeding with the distraint, he may break open an outer door. A breach of the peace in so doing should be avoided. The rule that "a man's house is his castle" extends to a barn or outhouse. ${ }^{25}$ There is a question as to whether or not the landlord may lift a latch of a door, to open it, to make a distraint. During the absence of a tenant and his family the defendants came to his house with a landlord's warrant, and, finding the door locked, opened the front door with a key which they brought and made a levy on and sold certain goods, and it was held that the entry was wrongful. No violence was used, but force in the legal sense was employed to turn the key and open the door. It was remarked that some conflict of authority exists on the question whether the landlord may lift the latch of a door which is shut but not locked; there was no need to enter into the controversy. However, it was suggested that if a man merely latches his door, he may, perhaps, he regarded as inviting all persons to enter his house who have business therein. ${ }^{26}$ In

22 Rees $v$. Emerick, 6 S. \& R. 286.

23 Richards $v$. McGrath, 100 Pa. 389.

24 Richards $v$. McGrath, IoO Pa. 389.

25 Semayne's Case, vol. I, part I, Smith's Leading Cases (8th ed.), 244. 26 Murray $v$. Vaughn, I6 Pa. C. C. R. 657. 
New York it has been held that opening a door is a breaking, within the meaning of the law. Lifting a latch is, in law, just as much a breaking, as the forcing of a door bolted with iron. The fastening is enough. Sliding down a window fastened with pulleys will not be allowed. ${ }^{27}$ This seems a very proper doctrine to hold. In case of a place of business when every one having business to transact with the proprietor has an invitation to enter by lifting a latch during business hours, it might be well to hold that a sheriff or constable can enter to levy or distrain, but in case of a dwelling-house it would be very improper to hold that they can enter by lifting a latch. In case of a dwelling-house the usual course is to ring or knock, and if there is no response the conclusion will be that the proprietor is away. To allow a sheriff or constable to lift a latch and to enter a dwelling-house with no one about would be intolerable. As long as the rule is to be made for all kinds of buildings without distinction, the New York rule seems to be the proper one to adopt. The right of access shotld be confined to an open door or window, the presumption being in such cases that some one is in the house. To even allow an entry through an open window is bad enough, and the law should not be made worse than it is. Not a case has been discovered in Pennsylvania in which any entry into an open window was made, and the indication is that according to a custom and usage in this state, since its foundation, distraints have not been made generally in that way. If that is so, it seems that an ancient precedent in England permitting such an entry ought to be disregarded. That a sheriff or constable should be permitted to get through an open window into a dwelling-house, which may be for the time unoccupied, seems as bad as the cases of lifting a latch or unlocking a door to enter.

\section{Distraining upon the Goods.}

26r. The constable enters upon the premises and makes a

27 Curtis $\approx$. Hubbard, I Hill's Rep. N. Y. 336. 
seizure of such things as are liable for rent and proceeds to make an inventory of so many of the goods as he judges to be sufficient to cover the rent distrained for, together with the charges of the distress. The Supreme Court held that the seizure of property necessary to complete a distress need not be an actual seizure of the particular goods. If the landlord gives notice of his claim for rent, and declares that the goods which he names shall not be removed from the premises until the rent be paid, it is a sufficient seizure. ${ }^{28}$

\section{Rescue of Goods Distrained.}

262. Upon any pound-breach or rescous of goods or chattels distrained for rent, the person or persons grieved therein may recover treble damages and costs of suit against the offender or against the owner in case goods afterwards come to his possession. ${ }^{29}$ "Upon any pound-breach or rescous of goods or chattels distrained for rent, the person or persons grieved thereby, shall, in a special action upon the case for the wrong thereby sustained, recover his, her or their treble damages and costs of suit, against the offender or offenders in such rescous or pound-breach, any or either of them; or against the owner or owners of the goods distrained, in case the same be afterwards found to have come to his or their use or possession." 30 In case of pound-breach the distrainer may follow the goods and retake them and impound them again. ${ }^{31}$

\section{Interference with Distraint Proceedings.}

263. A landlord's distress warrant is not legal process within the meaning of $\S 8$ of the act of March $3 \mathrm{I}, \mathrm{1} 860$, and an indictment will not lie under that section for resisting the execution of that warrant. Until an appraisement has been made the constable is only the landlord's bailiff. After the

28 Furbush v. Chappel, 105 $\mathrm{Pa}$. 187.

29 Act March 21, 1772, I P. \& L. Dig. 2642; P. L. 370.

30 Act March 21, 1772. 31 Woglam v. Cowperthwaite, 2 Dall. 6\%. 
appraisement the case might be different. The act of 1772 gives remedy for the rescue of goods distrained, but indictment will not lie. ${ }^{32}$ The owner of a leased piano was held liable in damages for removing it from the premises of the lessee after the landlord had distrained upon it for rent; but treble damages under the act of March 21, I772, were not recoverable, because the owner had no knowledge of the distress. No notice that the piano was leased or hired was given to the landlord as required by the act of May 13,1876 , which exempts musical instruments from levy and sale, or an execution or distress for rent. ${ }^{33}$

\section{Unreasonable or Excessive Distraint.}

264. By the statute of Marlebridge ( 52 Hen. III c. 4), in force in Pennsylvania, "distresses shall be reasonable, and not too great; and they that make unreasonable and undue distresses shall be grievously amerced for the excess of such distress." The remedy for a party aggrieved under this statute is by an action on the case and not trover or trespass. ${ }^{\mathbf{3 4}}$ It often happens that constables, in giving notice to tenants of a distraint enumerate certain articles and then notify the tenant that all the goods on the premises are distrained upon. If this be so, it would seem that great injustice may be done a tenant, especially when all the goods in a store, factory or the like, are distrained upon. It appears to be the duty of the constable to exercise his judgment as to the quantity of goods to be distrained upon; and, consequently, the rule is, that the landlord will not be liable for a trifling excess. To hold the landlord liable, it is not necessary that the proceedings should have gone further than a levy under a distress warrant. If there be but one thing on the premises which can be taken, so that the landlord must either take it or go without his distress, an

32 Commonwealth $v$. Nichols, $4 \mathrm{~Pa}$. Dis. R. 318.

33 Delp $v$. Hoffman, 7 Pa. Dis. R. 256.

34 Taylor's Landlord and Tenant, $\$ 730$. 
action will not lie, although the value of the thing taken greatly exceed the amount of rent due. In case the tenant causes a writ of replevin to be issued, he will be required to give security for double the value of the goods distrained upon; and, in some cases, the amount of this security may be enormous, by reason of an excessive distraint.

Placing Watchman.

265. Upon the distraint being made, a watchman may be placed in charge of the goods to prevent their sale or removal, or the landlord may remove the goods immediately, and the tenant should have notice of the place to which the goods have been removed.

\section{Leaving Goods on Premises.}

266. It is usual to leave the goods on the premises, the landlord taking the risk of removal, or placing a watchman over them, or taking security for the goods.

\section{Notice, etc., to Tenant.}

267. A copy of the inventory, with a notice of the distress, and the cause of the taking, should be left in the house with the tenant, or some one for him. Within five days next after the distress taken, and notice thereof or before the sale, if the tenant has any defence to make to the payment of the rent, or the distress, he may cause the goods distrained upon to be replevied.

\section{Tender of Rent.}

268. In order to stop a distraint or other proceeding of the landlord, it sometimes will become necessary to pay the rent; and, in endeavoring to do so, the laws respecting a tender of money should be regarded. To make a legal tender, the proper kind of money should be obtained, such as gold coin, legal tender notes, etc. The debtor must actually produce and offer the money to the party entitled to payment, or his agent authorized to receive payment with- 
out qualification or condition. Where a sale of goods under a distress for rent has been commenced and the tenant tenders the landlord the difference between the amount realized by the sale and the full amount of rent claimed with costs, the refusal of the tender and the continuance of the sale render the landlord liable in an action of trespass, for the value of the goods afterwards sold, notwithstanding the proceedings before the tender were legal and regular. ${ }^{35}$ The tender was made to the constable and the attorney for the landlord in legal tender notes. Silver coins less than a dollar are made a legal tender for debts not over $\$ 10 .^{36}$ Trade dollars are not good for legal tender. ${ }^{3 \pi}$ Silver dollars of the weight of four hundred and twelve and one-quarter grains Troy, of standard silver are made a legal tender, except where otherwise stipulated by contract. ${ }^{38}$ Foreign gold or silver coins are not a legal tender. ${ }^{39}$ Gold coins of the United States are made a legal tender. ${ }^{40}$ United States notes are made a legal tender. ${ }^{41}$ Bank notes are not made good for a legal tender. A tender was made of notes of the Branch Bank of Harrisburg and it was held that they were not a legal tender. ${ }^{42}$ If a tender is made in bank notes not made a legal tender and they are not objected to on that ground but the tender is refused it seems that the tender will be good or excused. ${ }^{43}$

\section{Replevin.}

269. If a landlord should distrain for rent and there should be objections to make to his so doing, action of replevin can be brought.

35 Richards $\%$ McGrath, Ion Pa. 389.

36 Vol. I. Sup. Rev. Stat. U. S. 264.

37 Vol. I, Sup. Rev. Stat. U. S. 124.

38 Vol. I. Sup. Rev. Stat. U. S. 152.

39 Sec. 3584 , Rev. Stat. U. S. 708.

40 Sec. 3585 , Rev. Stat. U. S. 708.

4 I Sec. 3588, Rev. Stat. U. S. 708.

42 Cornell v. Green, io S. \& R. 14.

43 Brown v. Dysinger, I Rawle, 408. 
The Time for Issuing the Writ.

270. After the distraint, the landlord cannot proceed to appraise and sell until five days have expired. Some persons have the impression that the writ of replevin must be issued and served within the five days. They are mistaken, for the tenant can have the replevin any time before the sale. However, unless the writ be issued within the five days, the constable may proceed with the appraisement and sale.

\section{Order for the writ.}

271. The order for the writ to be taken to the clerk of the court of common pleas can be as follows:

\section{A. B.}

v.

\section{D., landlord;}

E. F., bailiff.

Issue writ of replevin for (here describe the goods distrained upon).

Value of goods, \$-; Rent, \$-.

Returnable (fill in the next return-day of writs).

\section{Entering Security.}

\section{G. H., Attorney for Plaintiff.}

272. Upon the receipt of the order for the writ, the clerk of the court will prepare the writ and deliver it to the plaintiff's attorney; but before the sheriff serves the writ, security will have to be given as required by the act of 1772 . The bond must be executed by the plaintiff and one responsible person or trust company as surety for double the value of the goods distrained. The sheriff usually takes the word of the plaintiff or his attorney as to the value of the goods. If the value of the goods should be double the amount of the rent, it seems as if the valuation ought to be satisfactory. The bond is prepared by the sheriff, and is made to him, and is conditioned for the prosecution by the plaintiff of his suit against the defendant with effect and without delay, and for the return of the goods in case the decision of the suit 
shall result in favor of the defendant. Formerly in the city of Philadelphia, the sheriff was liable for not taking proper security, but he now is relieved of the responsibility by the act of April 10, 1873, which requires the bond and security to be approved by a judge. In Philadelphia the surety makes an affidavit as to his property (as required by the rule of court), which is presented to a judge. Upon the judge's signing his approval, the clerk of the court certifies such approval to the sheriff who enters the writ and prepares the bond. Upon the execution of the bond, the deputy sheriff serves the writ. Upon the constable being served with the writ he usually stops proceedings and surrenders possession of the goods.

\section{The Pleadings.}

273. The plaintiff should promptly file the declaration. The defendant thereupon files what is called an avowry, whereby he justifies his action by stating the renting and the distraint for rent. In case an owner of goods, not the tenant, claims that the goods belong to him, and that they are not liable to be distrained upon, he sets forth the necessary facts to raise issue as to property. The plaintiff having filed a reply joining issue, the case is then ready for trial. The constable, if he is joined, files what is called a cognizance, wherein he justifies his conduct as bailiff. Where, by a lease, the landlord has the right to distrain the tenant's goods for thirty days after removal from the demised premises, the plea, hors de son $f e e$, is a proper one to raise the issue whether the distress was made within thirty days after the removal of the goods distrained. The plea means, "I am no longer your tenant and am with my goods out of your land." In England at common law, the property of the tenant could never be taken after the disruption of the relation of landlord and tenant and a removal from the demised premises. To the said plea the landlord can reply that, "The goods so distrained 
were, by the terms of the lease, made liable to distress during thirty days after removal and were distrained within said thirty days." 14

Trial and Judgment.

274. By the statute of 17 Charles II, in force in Pennsylvania, the jury may find the amount of the rent in arrear and the value of the goods distrained upon. Upon obtaining judgment, the landlord can have an execution to recover the amount of rent found to be due. If the amount of rent is not recovered by such execution, the landlord brings suit on the replevin bond. He should have an assignment made by the sheriff and he should bring suit in his own name; concerning the value of the goods, he can offer the finding of the jury as to their worth. The attorney for the landlord should inform the judge that his client desires the benefit of the law, and that he desires the judge to instruct the jury to find the rent in arrear, if any, and the value of the goods. If this is not done, the landlord will be entitled only to a judgment for the return of the goods and for such damages as the jury may find. In such case, however, the landlord will have his right of action upon his replevin bond. As the landlord cannot claim property in him, a claim-property bond would be out of place.

Replevin the Proper Remedy for Illegal Distraint upon Strangers' Goods.

275. The owner of a chattel in the possession of a tenant, which hàs been distrained for rent and sold, cannot maintain trover for it against the landlord where notice of the distress was given to the tenant. The notice may be given to the tenant or to the owner at the landlord's discretion. The principal object of notice is to enable and, indeed, compel the proper party to contest the legality of the distress before

44 Mather v. Wood, I Pa. Dis. Rep. 793. 
the property is sold, and thus prevent the landlord's being involved in unforeseen difficulties. ${ }^{45}$

\section{Liability of Landlord for Distraining on Goods of a Stranger. .}

276. Under the act of March 21, 1772, replevin is the proper remedy to be used by a person whose goods have been improperly distrained upon by a landlord for rent due by a tenant. Where such a person receives notice of the distress, and the landlord postpones the sale to give him an opportunity to bring replevin, which he refused to do, he cannot after the sale bring trespass against the landlord for the value of the goods. ${ }^{46}$ A landlord who distrains upon goods knowing them to be the property of another, left with the tenant for sale on commission, is a trespasser ab initio, and is liable to the owner of the goods in an action of trespass. ${ }^{47}$

\section{Appraisement of the Goods.}

277. At the expiration of the five days, the person distraining, with the sheriff, under-sheriff or constable, causes the goods distrained upon to be appraised by two reputable freeholders. "The day of the distress is to be excluded in the computation of the five days. ${ }^{48}$ The appraisers are sworn by the officer to appraise the goods. Before an appraisement can be lawfully made, five clear days must intervene after the distress taken; and notice thereof, with the cause of taking must be left at the mansion-house or most notorious place on the premises. Notice must be in writing and should inform the tenant or the owner of the goods taken and the amount of rent in arrear. ${ }^{49}$ Before a landlord can lawfully sell goods distrained for rent, he must cause the goods and chattels so distrained to be appraised by two reputable freeholders. An appraisement by three persons was irregular. As the pro-

45 Caldclegh $v$. Hollingsworth, 8 W. \& S. 302.

46 Esterly Machine Co. $v$. Spencer, I 47 Pa. 466.

47 Brown $v$. Stackhouse, 155 Pa. 582.

48 Brisbin $v$. Wilson, $60 \mathrm{~Pa} .452$.

49 Snyder $v$. Boring, 4 Pa. Super. Ct. Rep. 196. 
ceeding is statutory, the direction of the statute must be followed, or its protection will be lost. If the seizure is irregular it is a trespass; if the seizure is regular, but the subsequent steps are not in accordance with the statute, the landlord becomes a trespasser $a b$ initio. $^{50}$ The landlord is not compelled to weigh and measure all the goods in a store which he has distrained, nor need he detail every article or notion in a stock of millinery goods. The inventory should be so full and complete as to inform the tenant of the goods distrained and for which he may issue a replevin. ${ }^{51}$ "A failure to have the appraisement made as required by the statute is fatal to the proceeding of distress, and renders the landlord liable as a trespasser $a b$ initio." 52 It is immaterial whether the property belongs to the tenant or to a stranger, so far as the liability for a tortious sale is concerned. ${ }^{53}$

\section{Sale of Goods.}

278. After the goods are appraised, they are sold at public sale by the constable, after the six days' public notice. Goods distrained for rent may be impounded on the premises for a reasonable time after five days, and seven days would be such reasonable time. ${ }^{54}$ As there has been some doubt as to the right to keep the goods in the tenant's house after the five days, sometimes the precaution is taken to get the tenant's consent to such occupancy. At all events, if the goods are to be kept over such reasonable time, the tenant's consent should be procured. In computing the six days' notice of the sale, the day on which the notice of the sale is given is excluded, and the day of the sale included. In computing the five days which must elapse before the appraisement, the day of seizure is excluded. If the fifth day

50 Snyder v. Boring, 4 Pa. Super. Ct. Rep. 196.

5I Richards 2 . McGrath, I00 Pa. 389.

52 Wyke $v$. Wilson, $173 \mathrm{~Pa}$. 12.

53 Hazlett $v$. Mangel, 9 Pa. Super. Ct. I39.

54 Wiatt $v$. Ewing, 7 Phila. R. 195. 
falls on Sunday it is also excluded, so that if goods be distrained on Tuesday, an appraisement cannot properly be made before the succeeding Tuesday. The appraisement being made on Tuesday, the five days allowed for a replevin will end on Monday. ${ }^{55}$ A distress with notice thereof on February $\mathrm{I}$, and an appraisement with a notice on February 7 , of the sale to take place on February I3, and a sale in pursuance of such notice will satisfy the act of March 21, 1772, regulating the proceedings in cases of distress for rent. The appraisement and "six days' public notice" required by the statute are, in the order named, conditions precedent to a sale; but there is no express provision in it or necessary implication from its language, which postpones the notice of the sale to a day subsequent to the appraisement. A notice of the distress is valid if served on the day that the distress is made. It sustains the same relation to the distress, in the order of procedure, as the notice of sale does to the appraisement. It is as necessary to a valid appraisement of the property distrained, as a six days' public notice is to a lawful sale of it. A notice given on Tuesday, the day of the appraisement, is sufficient to authorize a sale on the following Monday of the goods distrained; the intervening Sunday has no effect on the computation, because it did not fall on the last day of the period. The computation of time in such case is governed by the act of June 20,1883 , providing for the exclusion of the first and the inclusion of the last day. ${ }^{56}$ A postponement of the sale for a week will be permissible. ${ }^{5 i}$ In case of a postponement of a sale, it will be well to get the written consent of the tenant.

\section{Manner of Sale.}

279. Goods must be sold separately or in parcels, not the entire stock in the mass. They may be sold in such lots as 
shall be best calculated to bring the highest price. If sold in too large parcels the injured party may have a remedy. ${ }^{58}$

\section{Exemption of Rented Pianos.}

280. By the act of May I3, I876, all pianos, melodeons and organs leased or hired by any person or persons, residing in this commonwealth, shall be exempt from levy and sale on execution and distress for rent due by such person or persons so leasing or hiring any such piano or pianos, melodeon or melodeons, organ or organs, in addition to any articles now exempt by law; Provided, that the owner or owners of any such piano, melodeon or organ, or his or their agent or the person or persons so leasing or hiring the same, shall give notice to the landlord, or his agent, that the instrument is leased or hired. In order to have a piano exempted under the act of May I 3, I876, the noticc required by the law should be given to the lessor when the piano is delivered to the tenant, or before the right of distress has accrued. ${ }^{59}$ A piano was rented to the wife of a tenant for her private use, with the privilege of purchasing, and the piano was distrained upon for rent, and it was lield that it was simply the property of a stranger found on the demised premises, and left for no purpose of trade. It did not belong to or further the business of the tenant, but was simply leased by his wife. ${ }^{60}$

\section{Exemption of Sewing Machines.}

28r. It would seem that sewing machines rented or hired are unprotected from distress for rent. By the act of April I 7, I 869, sewing macluines bclonging to seamstresses are exempted from distress. By the act of March 4, I870, sewing machines used and owned by private families are also exempt. A tenant rented a sewing machine. A landlord's warrant was issued for the collection of rent, under which

58 Richards 2 . McGrath, Ioo Pa. 389.

59 McGeary $v$. Mellor, $87 \mathrm{~Pa}$. 46r; Rohrer $v$. Cunningham, $138 \mathrm{~Pa} .162$.

60 Kleber $v$. Ward, $88 \mathrm{~Pa} .93$. 
distress was made upon some personal property, including the sewing machine. The lease contained a waiver of exemption. At the hour fixed for the constable's sale the owner of the sewing machine gave the constable notice that it was his property, and forbade his selling the same as the property of the tenant, as it was only leased to him. The constable sold the other property, but not the sewing machine, and adjourned the sale of it for one week, notifying the owner of the fact. At the expiration of the week, nothing having been done in the meantime by the plaintiff, the constable put up the machine and sold to E. Batterton, who took possession of it. The owner of the machine then sued out a writ of replevin for it, and summoned the purchaser. The Supreme Court held, first, that the machine was not exempt under the act of April 17, 1869, because it did not belong to a seamstress; second, it was not exempt under the act of March 4, I870, as the property of the owner, because that act expressly excepts from its operation "persons who keep sewing machines for sale or hire;" third, that the owner could not claim it exempt as the property of the lessee. The latter had left it upon the premises, from which he had moved, and made no claim of ownership or demand to have it exempted, and at the date of the sale the lease had expired. It was not at that time a sewing machine "owned and used" by a private family within the meaning of the act; and that the owner should have caused the replevin to be issued before the sale. The claim for exemption is a personal privilege, and must be claimed by the tenant. ${ }^{61}$

\section{Liability of Goods Sold According to Instalment Plan.}

282. The rule that the goods of a stranger on demised premises in the way of business are not subject to distress is this: That "where the tenant in the course of his business is necessarily put in possession of property of those with whom

6r Bogert $v$. Batterton, 6 Pa. Super. Ct. R. $468^{\prime}$. 
he deals, or those who employ him, such property although on demised premises is not liable for rent due thereon from the tenant." The plaintiff was a furniture dealer and furnished certain furniture to the keeper of a boarding-house who agreed to pay $\$ 425$ for the use of the articles. She agreed to pay $\$ 25$ per week until the amount was paid, when said rent should cease, and the articles should become her property absolutely. It was provided that the title to the furniture should remain in the dealer until the tenant's obligation was complied with. These goods were distrained upon, were purchased at a constable's sale and removed by the purchaser. Held, that it was not the furniture of a boarder, but it was furniture in use of the proprietor of the house. As between the tenant and the furniture dealer the property belonged to the latter, but as between the tenant and her landlord, the same belonged to her, and was liable to distress. ${ }^{62}$

\section{Three Hundred Dollars Exemption Law.}

283. By the act of April 9, I849, property to the value of three hundred dollars (\$300), exclusive of all wearing apparel of the tenant and his family, and all Bibles and school books in use in the family [which remain exempted as theretofore]. owned by or in possession of the tenant, are exempted from distress for rent.

\section{Appraisers to be Appointed.}

284. The constable, upon the request of the tenant, summons three disinterested and competent persons, who are sworn or affirmed to appraise the property which the tenant may elect to retain. The wife's separate property may be distrained for rent due by the husband; the married woman's act, protecting the separate property of a married woman, does not alter the law of landlord and tenant. ${ }^{63}$ 


\section{Under-Tenants Cannot Claim Benefit.}

285. Tenants held demised premises expressly subject to the condition in the original lease, that they would not assign their term or sub-let the premises without the consent of the landlord. The tenants assigned the lease in violation of the condition. There was no consent of the landlord to the assignment, and no recognition by him of the sub-tenant. Neither the relation of landlord and tenant, nor of debtor and creditor, was established. It was held that the assignee, not being a debtor for the rent, was not entitled to the exemption of the statute as to the goods of his distrained upon. The claim was made against the original tenants. They were the debtors, within the meaning of the act, but they claimed no exemption; and those who came in under them, without the landlord's consent, had no right to claim it. ${ }^{64}$

\section{Refusal of Exemption.}

286. If a tenant's demand of exemption is refused, and the officer proceeds to sell, the tenant's right to the property is gone, and a right of action only remains for the wrong done by refusing the demand. ${ }^{65}$

\section{Who can Claim Exemption.}

287. Corporations, associations and partnerships cannot claim the exemption law for their property. The claim must be individual. ${ }^{66} \mathrm{~A}$ bachelor debtor may have the benefit of the exemption law, though it is generally spoken of as intended for the debtor's family. ${ }^{67}$ Non-residents are not entitled to the benefit of the law. ${ }^{68}$

\section{When Claim Should be Made.}

288. A claim for exemption should be made promptly. It

64 Rosenberger $v$. Hallowell, 35 Pa. 369; Bogert $v$. Batterton, $6 \mathrm{~Pa}$. Super. Ct. R. 468.

65 Bonsall $v$. Comly, 44 Pa. $442 . \quad 66$ Bonsall $v$. Comly, $44 \mathrm{~Pa} .442$.

67 Dieffenderfer $v$. Fisher, 3 Grant, 30.

68 Snow v. Dill, 6 W. N. C. 330. 
should be made before the sale, and generally before the advertisements are put up. ${ }^{69}$

\section{Request for Appraisement.}

289. The defendant must demand an appraisement; but any words which apprise the officer of his desire for the benefit of the exemption are sufficient. ${ }^{70}$

\section{How Claim is to be Made when Tenant is Absent.}

290. During the absence of the defendant, a child or any one of his family of proper age, his wife, attorney or agent, and perhaps a neighbor or relation as next friend, may claim the benefit of the law. ${ }^{71}$

Right to Distrain on Property Fraudulently Removed under Act of 1772.

291. By the act of March 21, I772, if a tenant fraudulently or clandestinely removes his goods from the demised premises with intent to prevent a distraint, the landlord, within thirty days after the goods are removed, can take and seize such goods wherever the same may be found, as a distress for the arrears of rent, provided the goods have not been sold bona fide and for a valuable consideration before such seizure.

A removal of the goods in the night is in itself clandestine, and is sufficient evidence of fraud. . . . Suppose the landlord should come to the premises for the purpose of distraining, and should refrain from a distress on the tenant's promising that he would pay the rent or give satisfactory security by a certain hour, and in the meantime his goods should remain where they were; and after this the tenant should remove the goods as soon as the landlord's back was turned, and all this in the daytime - this would be a palpable fraud. But where there is no evidence of more than a simple removal in the daytime without the knowledge of the landlord, there is no ground for presumption of fraud, nor will the law suffer it

69 Diehl v. Holben, $39 \mathrm{~Pa} .2$ 2 3. $\quad 70 \mathrm{Diehl} v$. Holben, $39 \mathrm{~Pa} .2 \mathrm{r} 3$.

7I Wilson v. McElroy, $32 \mathrm{~Pa}$. 82; Meitzler's Ap., $73 \mathrm{~Pa} .368$. 
to be presumed. The tenant is not bound to give notice to the landlord that he is about to remove his goods, nor is he under any obligation not to remove them; it is the landlord's business to be vigilant; he has the right to distrain whenever the rent has become due, and if he neglects it he runs the risk of losing this extraordinary remedy with which the law has favored him. $^{72}$

Goods of a Stranger Not to be Followed.

292. The goods of a stranger removed from the premises before levy are not liable to be followed and levied on off the premises under the act of $1772 . .^{33}$

\section{Goods Sold are Exempt.}

293. If goods have been sold to a bona fide purchaser having no knowledge of such removal, they cannot be distrained upon.

Rent Must be Due at Time of Removal.

294. In order to follow the goods under the act, rent must be due at the time of the removal. ${ }^{74}$

Right to Collect Rent not Due in Case of Fraudulent Removal under Act of 1825 .

295. By the act of March 25, 1825, and supplement, in Philadelphia, Pittsburg and Allegheny, if goods are fraudulently removed from the demised premises, with intent to defraud the landlord of his distress, the landlord can have his rent apportioned to the time of such removal, and follow and take the goods as a distress within thirty days from such removal; provided he makes oath or affirmation that he verily believes the goods were carried away for the purpose of defrauding him as aforesaid; And provided further, that goods sold bona fide and for a valuable consideration are excepted.

72 Grace $v$. Shively, 12 S. \& R. 216.

73 Sleeper $v$. Parrish, 7 Phila. R. 247.

74 Grace $v$. Shively, I2 S. \& R. 216. 


\section{CHAPTER XI.}

LIABILITY OF GOODS OF TENANT FOR TAXES OF LANDLORD.

\section{SECTION}

296. Act of April 19, 1883, providon tenant's goods for taxes ing for a right to distrain in cities of the first class.

Act of April 19, 1883, Providing for a Right to Distrain on Tenant's Goods for Taxes in Cities of the First Class.

296. "The receiver of taxes of the said cities of the first class, is hereby authorized and empowered to distrain and levy upon and sell any goods, chattels or personal property found on any premises on which the taxes are delinquent, or upon the goods, chattels or personal property of the owner of said premises, wherever the same may be found, whether in his own possession or in that of any trustee or other person for him, or in the possession of his executors, administrators or legal representatives." There is a provision among others to said act reading as follows: "And provided further, That when goods, chattels or personal property of any tenant shall have been levied upon, by virtue of the provisions of this act, the said receiver of taxes is hereby authorized, empowered and directed to proceed with due diligence, to collect from said tenant; and when the amount of taxes, costs and charges exceeds the amount of rent due, then only the amount of rent then due; but the lien of the levy shall remain upon said goods during the occupancy of said premises by said tenant, and all rents, after accruing, shall be applied to the extinguishment of said taxes, until the tax, charges and costs shall have been fully paid. The amount collected by said receiver of taxes shall be a lawful deduction from the rent due, 
or that may thereafter become due, and in the event of the refusal of any landlord to allow of said deduction to said tenant on account of rent, and shall refuse to accept the receipt of said collector in lieu thereof, then it shall be the duty of the city solicitor of said cities of the first class, to defend the said tenant in any action brought by the said landlord or his agent for the recovery of said rent from said tenant; the costs and expenses thereof to be paid by said city; Provided further, That in no case shall any tenant or tenants be compelled to pay the said tax, costs and charges, or any portion thereof, until the rent shall have become due and payable, neither shall said receivers of taxes follow said tenant's goods, chattels or personal property, to any other premises upon a previous levy, upon a change of residence of said tenants or a bona fide removal of said goods, in the ordinary course of business." 1

I 2 P. \& L. Dig. 4530 , § 169; 1883, P. L. 9, § 3. 


\section{CHAPTER XII. \\ RIGHTS TO CROPS AND EMBLEMENTS.}

SECTION

297. Definition of emblements.

298. Growing grass.

299. Things not of annual growth.

300. Right lost by forfeiture of lease.

301. Definition of waygoing crop.

302. Who entitled to the crop.

303. Straw included.

304. Must be fall grain.

305. Crop may be sold by tenant.

306. The protection of the crop.
SECrioN

307. Crop in case of execution.

308. Definition of a cropper.

309. Landlord not entitled to grain as rent until delivered.

310. Under orphans' court sale, crops as rent pass to purchaser.

311. Crops payable as rent, growing at the death of landlord, go to heirs.

\section{Definition of Emblements.}

297. The vegetable chattels, called emblements, are the corn and other products of the earth which are produced annually, not spontaneously, but by labor and industry.

\section{Growing Grass.}

298. A growing crop of grass, even if grown from seed, and though ready to be cut for hay, cannot be taken as emblements, because it is said the improvement is not distinguishable from what is a natural product, although it may be increased by cultivation.

\section{Things not of Annual Growth.}

299. Such things as are not of annual growth, and do not require the labor of the tenant, but are the permanent and natural product of the earth, such as trees, fruit and grass, are not emblements. ${ }^{1}$

I Reiff $v$. Reiff, $64 \mathrm{~Pa}$. I34. 
Right Lost by Forfeiture of Lease.

300. A tenant who is ejected for breaking the terms of his lease is not entitled to emblements. In the month of August, while corn and potatoes which had been planted by the tenant during the term were still growing and ungathered, the landlord entered an amicable confession of judgment in ejectment for conditions broken, and had the tenant put out of possession; and it was held that the articles in question could not be taken away by the tenant. ${ }^{2}$

\section{Definition of Waygoing Crop.}

301. Although a tenant for a certain period may not be entitled to emblements, yet by a custom in Pennsylvania he is entitled, like a tenant for an uncertain period, to what is known as the waygoing crop. The waygoing crop is the crop of grain sown in the fall to be reaped at the next harvest. ${ }^{3}$

\section{Who Entitled to the Crop.}

302. A tenant from year to year is entitled to the waygoing crop. ${ }^{4}$ This custom may be controlled by an express provision in the lease. ${ }^{5}$

\section{Straw Included.}

303. The straw is included. ${ }^{6}$

\section{Must be Fall Grain.}

304. The tenant cannot sow the land with spring grain, and cut it after the term is out. ${ }^{7}$

2 Hunter $v$. Jones, 2 Brewster's Rep. 370.

3 Demi v. Bossler, I P. \& W. 224.

4 Clark $v$. Harvey, $54 \mathrm{~Pa}$. 142.

5 Craig v. Dale, I W. \& S. 509.

6 Craig v. Dale, I W. \& S. 509.

7 Demi v. Bossler, I P. \& W. 224. 
Crop May be Sold by Tenant.

305. A tenant may dispose of his waygoing crop as he may of an article of personal property. ${ }^{8}$

The Protection of the Crop.

306. The landlord or any other person who injures the waygoing crop can be sued by the tenant for damages. ${ }^{9} \quad \mathrm{~A}$ trespass by the landlord on the waygoing crop cannot be justified by a breach of the tenant's contract or bad husbandry. The redress must be by suit, and not by confiscation of the tenant's rights. ${ }^{10}$

\section{Crop in Case of Execution.}

307. A lessee of land encumbered with a judgment prior to the lease under which the premises are levied upon and sold, is entitled to the waygoing crops sown by him prior to the levy and condemnation in preference to the sheriff's vendee. ${ }^{11}$

\section{Definition of a Cropper.}

308. If one be hired to work land, receiving for his compensation part of the produce, he is a cropper, and not a tenant. He has no interest in the land, but receives his share as the price of his labor. The possession is still in the owner. ${ }^{12}$

\section{Landlord Not Entitled to Grain as Rent until Delivered.}

309. Where the rent of a farm is payable in a share of grain raised on it, division and delivery are essential to vest the title to the grain in the landlord.

\section{Under Orphans' Court Sale, Crops as Rent Pass to Purchaser.}

310. By an orphans' court sale of the property, the right

8 Shaw $v$. Bowman, 9I Pa. 4I4.

9 Forsythe $v$. Price, 8 Watts, 282.

Io Clark v. Harvey, $54 \mathrm{~Pa}$. I42. II Bittinger v. Baker, $29 \mathrm{~Pa} .66$. I2 Adams v. McKesson's Ex., 53 Pa. 81. 
to a share of the growing crops reserved as rent passes to the purchaser. ${ }^{13}$

Crops Payable as Rent, Growing at the Death of Landlord, go to Heirs.

3II. A crop was growing at the death of the intestate; it was harvested and divided afterwards, the tenant taking his part and delivering to the landlord his share. It was held, as a rent payable in kind, it passed with the inheritance, and belonged to the heirs, rather than the administrator. ${ }^{14}$

I3 Burns v. Cooper, 3I Pa. 426.

I4 McDowell $v$. Adams, $45 \mathrm{~Pa}$. 430; Waugh's Exrs. v. Waugh, 84 Pa. 350. 


\section{CHAPTER XIII.}

POWER OF TENANT TO BIND OWNER'S PROPERTY FOR MECHANICS' LIENS.

SECTION

312. In what cases properties are bound.

313. Act of May I8, 1887, re-
SECTION

quiring written consent of landlord for tenant to bind premises for repairs, etc.

\section{In what Cases Properties are Bound.}

312. It has been held that a lessee under an improvement lease, who has contracted with his lessor to put up a building on the land, may, by his contract with a mechanic and materialman, bind the estate of the lessor. ${ }^{1}$ But the presence of an express covenant by the lessee to build is not that which distinguishes a building contract from an improvement lease, where the work is to be done by the tenant and his servants. There was no express covenant to build, but the amount of rent the lessee was to pay was directly affected by his omission to build, or his actual building. ${ }^{2}$ Where a tenant contracts with a landlord to build, for compensation to be made by the landlord, either in money or the occupation and use of the premises he is as an ordinary contractor to build. $\mathrm{He}$ is the landlord's agent, holding possession for him, building for him at ultimate cost; and the building is liable to lien as in all other cases of building by contract. Occasionally such contracts have been inadvertently called improvement leases, but they are not in the ordinary meaning of the term. Improvement leases do not ordinarily contemplate the pur-

I Reed $v$. Kenney, 4 W. N. C. 450.

2 Barclay $v$. Wainwright, $86 \mathrm{~Pa}$. 19I.

130 
chase of material for building and the employment of mechanics, but simply the labor of the tenant and his servants. A permission or license to build, without a duty on the tenant to do so, is not sufficient to subject a property to a lien. If the building is erected with the landlord's consent, and at his ultimate expense, a lien may be filed. ${ }^{3}$ The mechanics' lien laws were originally intended to apply to cases of the erection of new buildings, but by the act of August I, I868, these laws were extended in Philadelphia to claims for the repair, alteration or addition to any house or building, when the same is for not less than fifty dollars. It is provided, however, that such extension will not apply where the repairs, alterations or additions are done by a lessee or tenant, without the written consent of the owner or his agent. The lien dates from the time of the filing of the claim, and until the lien is filed the owner may convey the property clear of the lien. Whether the insertion of a clause in a lease, authorizing the making of alterations and improvements by the lessee, constitutes such a written consent on the part of the lessor as authorizes the filing of a lien under said act, depends upon the question whether the cost of such alterations or improvements is to be borne by the lessor or the lessee. If by the former, the consent is sufficient to authorize the filing of such lien; if by the latter it is not. A tenant agreed to make repairs, to make no alterations or improvements without the lessor's consent, and further to leave all alterations at the expiration of the term, for the lessor's benefit. It was held that the terms of the lease indicated no intention that the expense of the repairs was to be borne by the lessor, and that therefore a lien could not be filed under the act of $1868 .{ }^{*}$ In case a landlord makes an agreement with his tenant as to the erection of buildings and improvements, care should be taken not to subject the estate of the lessor to mechanics' liens. The agreement should be carefully written under the

3 Hall v. Parker, $94 \mathrm{~Pa}$. Io9.

4 Boteler v. Espen, $99 \mathrm{~Pa} .313$. 
supervision of counsel acquainted with the authorities upon the nice distinctions the courts have made.

Act of May 18, 1887, Requiring Written Consent of Landlord for Tenant to Bind Premises for Repairs, etc.

3I3. By this act the property of the landlord will not be liable to liens for repairs, alterations or additions where the same has been altered by the tenant without the written consent of the owner or his agent, and notice must be given to the owner or his agent at the time of furnishing the materials or performing the work of an intention to file a lien. 


\section{CHAPTER XIV.}

\section{INSURANCE BY TENANTS.}

\section{SECTION}

314. Such insurance distinguished from other insurance.

\section{Such Insurance Distinguished from Other Insurance.}

314. A leasehold interest in buildings is insurable. A provision that the policy shall become void "if the assured is not the sole and unconditional owner of the property, or if the building stands on ground not owned in fee simple by the assured, or if the interest of the assured is not truly stated in the policy" is not applicable to an insurance of such an interest. A policy of insurance, like any other contract, is to be read in the light of the circumstances that surround it. ${ }^{1}$

I Tool v. Ins. Co., 25 W. N. C. 370. 


\section{CHAPTER XV.}

\section{EVICTION.}

SECTION

315. Eviction in part does not suspend the whole rent when tenant remains.

316. Landlord taking possession of ruins after a fire.

317. Physical expulsion not necessary.

3I8. Where tenant takes possession in case of tenant's desertion.
SECTION

319. Landlord using a way.

320. Operation against current rent.

321. Eviction by an injunction.

322. No eviction by conduct not depriving tenant of the use of property.

323. Waiver of eviction by paying rent.

Eviction in Part does not Suspend the Whole Rent when Tenant Remains.

315. An eviction of a tenant from a portion of the demised premises, when the tenant continues in possession of the remaining part, using and enjoying it, does not work a suspension of all subsequent rent; and the tenant is liable to his landlord, in an action for use and occupation, for such portion of the rent as the value of the part retained bears to the whole. If a tenant be evicted from a part of the demised premises, he may remove from the residue, and thereby wholly relieve himself from the payment of future rent. ${ }^{1}$

\section{Landlord Taking Possession of Ruins After a Fire.}

316. If the landlord takes possession of the ruins of his premises destroyed by fire, for the purpose of rebuilding, without the assent of his tenant, it is an eviction. If with his 
assent, it is a rescission of the lease and, in either case, rent will be suspended. ${ }^{2}$

Physical Expulsion Not Necessary.

3I7. The modern doctrine as to what constitutes an eviction, is that actual physical expulsion is not necessary, but any interference with the tenant's beneficial enjoyment of the demised premises will amount to an eviction at law; and it has been held that a landlord's refusal to allow an undertenant to enter the premises, under threats of suit, whereby the tenant is deprived of the underletting, is such an interruption of the latter's right as amounts to an eviction. ${ }^{3}$ If the landlord claims, and uses, certain privileges upon the demised premises against the tenant's consent, he must show a reservation of them. or the rent is suspended. ${ }^{4}$

\section{Where Landlord Takes Possession in Case of Tenant's Desertion.}

3I8. C. rented a tavern-house to $S$. for one year from April I, I 868. In January, I869, a constable levied on the goods of S. for taxes. Before the sale, S. left the premises; the constable left the key with $C$. On the day after the sale there was a bill "To let" put upon the premises. In I869 a new tenant leased from C., who had the key. After S. left and before the expiration of the term, C. made some repairs to the bar-room. The claim was for rent from December, I868, until April I, I869. It was held that taking care of the key, and repairing after the tenant had voluntarily left, was no eviction. He would have been entitled to enter if he had returned, but he did not return. He was neither put out nor sold out by the plaintiff. ${ }^{5} \quad$ A. demised certain premises to B., for business purposes, for a certain time. Before the lease expired $\mathrm{B}$. locked the premises, moving certain goods, but

2 Magaw v. Lambert. 3 Barr. 444; Hoeveler v. Fleming, 9I Pa. 322.

3 Dorian $v$. Chase, 2 W. N. C. 609.

4 Vaughan $v$. Blanchard, 4 Dall. 124.

5 Pier v. Carr, 69 Pa. 326; Milling $v$. Becker, $96 \mathrm{~Pa}$. I82. 
leaving others. A. thereupon broke the lock of the door, removed B.'s signs and remaining goods, and used the rooms for the remainder of the term for his own purposes. Held, that there had been an eviction. ${ }^{6}$

When a tenant is evicted he is discharged from the rent for the time following, but not for that due before eviction. ${ }^{\text {T }}$

\section{Landlord Using a Way.}

319. A landlord, after he made a lease, claimed a right of passage through the cellar leased to another cellar back, though he had other communication thereto, and had actually used this privilege against the tenant's consent. As the privilege had not been reserved, the rent was suspended. If the lessor enter into part, the whole rent is suspended; for the lessor cannot apportion it by a wrongful act of his own. ${ }^{8}$

\section{Operation Against Current Rent.}

320. Eviction of the tenant by the landlord has no operation on rent already due; it suspends the rent of the month, quarter, or other portion of time running on at the time of the eviction. The suspension of the rent is intended as a punishment, and operates in the nature of a forfeiture. ${ }^{9}$

\section{Eviction by an Injunction.}

32I. When a tenant is enjoined by his landlord from using the demised premises by an ex parte injunction, there may be an eviction. ${ }^{10}$

\section{No Eviction by Conduct not Depriving Tenant of the Use of Prop- erty.}

322. When the rental of a house is to be a sum certain and the board of the lessor, mere annoyances by the language

6 Burr v. Cattnach, ig W. N. C. 22.

8 Vaughan $v$. Blanchard, I Yeates, 175.

9 Kessler $v$. McConachy, I Rawle, 435.

Io Pfund $v$. Herlinger, Io Phila. I3. 
and general conduct of the lessor do not amount to an eviction, unless they are of such a character as to prevent the tenant from enjoying the house to its full capacity. ${ }^{11}$

Waiver of Eviction by Paying Rent.

323. Where a tenant, after eviction from a part of the demised property continues to pay rent without setting up the eviction as a defence, he waives his rights, and his subsequent holding over, not only after the eviction but after the expiration of the term in which it occurred, is under a new or implied agreement to pay at the same rate for the use and occupation of so much of the demised property as remained in his possession after the eviction. ${ }^{\mathbf{1 2}}$

II Ewing v. Cottman, 43 W. N. C. 525.

12 Ward's Est., $22 \mathrm{~Pa}$. C. C. R. 284. 


\section{CHAPTER XVI.}

SURRENDER.

SECTION

324. Parol surrender of lease for more than three years.

325. Surrender must be accepted.

326. Evidence of acceptance.

327. Surrender to agent.

328. Effect of surrender on request.
SECTION

329. Surrender by a tenant does not extinguish the term of a sub-tenant.

330. Effect of silence of landlord upon a surrender.

\section{Parol Surrendex of Lease for More than Three Years-}

324. The fact that a lease is for a longer period than three years does not prevent a rescission thereof by parol, when accompanied by a surrender of the lease and premises by the tenant to the landlord, and the acceptance thereof by the latter. ${ }^{1}$

\section{Surrender Must be Accepted.}

325. A tenant surrendered his term to his landlord, and paid him the rent in full to that time; whereupon the landlord immediately took possession, and proceeded to repair the house by building a new bath-room, a new porch, putting in a new range, and making general repairs such as could not have been made while the house was occupied by a tenant. Judgment was obtained against the tenant, because his affidavit of defence did not state that a surrender of the lease was accepted by the landlord; and it was held that taking possession, repairing, and advertising the house for rent were 
all acts in the interest and for the benefit of the tenant, and did not discharge him from his covenant to pay the rent. ${ }^{2}$

\section{Evidence of Acceptance.}

326. Taking care of the key, cleaning and repairing by the landlord would not be conclusive evidence of the landlord's acceptance of a surrender. ${ }^{3}$

\section{Surrender to Agent.}

327. In an action to recover rent reserved under a written lease, an affidavit of defence which alleges that the defendant lessee surrendered possession to A. B., the agent for the plaintiff, and that possession thereof was accepted by hin, is a good affidavit and sufficient to carry the case to a jury. ${ }^{4}$ It was held that agents for managing real estate can accept surrenders. ${ }^{5}$ When a tenant abandons leased premises with notice to the agent of the lessor, who had collected rent for the premises, he will not be relieved from liability under the lease unless it is shown that the agent has authority to accept a surrender, or unless the lessor ratify his act. ${ }^{6}$

\section{Effect of Surrender on Request.}

328. A surrender, with an acceptance of the keys, is not necessarily a surrender of the term. But where there is a precedent request by the landlord for the keys, his acceptance of them is an acceptance of the term. ${ }^{7}$

Surrender by a Tenant does not Extinguish the Term of a SubTenant.

329. A tenant after sub-letting a part of the demised premises, assigned his term to a stranger. Three days later,

2 Breuckmann $v$. Twibill, 89 Pa. 58; Lane $v$. Nelson, I67 Pa. 602.

3 Milling $v$. Becker, $96 \mathrm{~Pa} .182$.

4 De Morat $v$. Falkenhagen, $148 \mathrm{~Pa} .393$.

5 Weightman $v$. Harley, 20 W. N. C. 470.

6 Murphy $v$. Lòsch, $148 \mathrm{~Pa}$. 171.

7 Reaney $v$. Fannessy, I4 W. N. C. 9 I. 
the assignee surrendered the lease to the landlord, who immediately granted him a new lease for a longer term. This arrangement was made without notice to, and in disregard of, the known rights of the sub-tenant. Held, such surrender and new demise did not extinguish the term of the sub-tenant: he was entitled to hold thereafter, not under or in subordination to the new lease, but in hostility to it; and his goods could not be distrained by the landlord for rent due from the assignee on the new lease.

Nor did the landlord thereafter sustain any relation to the sub-tenant out of which the right to distrain upon the latter's goods, for rent in arrear on the sub-lease, could arise; if such right subsisted in the landlord, after the surrender, it passed out of him by virtue of the new lease which he granted to the assignee. $^{8}$

\section{Effect of Shlence of Landlord upon a Surrender.}

330. In a suit for rent a tenant paid all the rent due by him at the time of his removal, to the agent of the landlord; and handed to him the keys of the premises, and surrendered possession thereof to him, which he accepted without comment. The silence of the agent was considered to be an acceptance of the surrender, because he ought to have declared his intention to hold the tenant responsible for future rent, if that was his purpose. Silence is acquiescence in such cases. $^{9}$

8 Hessel $v$. Johnson, $142 \mathrm{~Pa} .8$.

9 Weightman $v$. Harley. 20 W. N. C. 470. 


\section{CHAPTER XVII.}

\section{FORCIBLE ENTRY AND DETAINER.}

SECTION

331. Act of assembly relating to same.

332. Must be a breach of the peace.

333. Forcible detainer.
SECTION

334. Tenant holder-over not liable for forcible detainer.

335. To constitute forcible entry or detainer there must be violence.

\section{Act of Assembly Relating to Same.}

33I. By the act of assembly of March 3I, I860, the provisions as to forcible entry and detainer are as follows :-

"If any person shall, with violence and a strong hand, enter upon or into any lands or buildings, either by breaking open doors, windows or other parts of the house, or by any kind of violence or other circumstances of terror, or if any person, after entering peaceably, shall turn out by force or by threats, or menacing conduct, the party in possession, every person so offending shall be guilty of a forcible entry, and on conviction, shall be sentenced to pay a fine not exceeding $\$ 500$ or to undergo an imprisonment not exceeding one year, or both, or either, at the discretion of the Court, and to make restitution of the lands and tenements entered as aforesaid.

"If any person shall, by force and with a strong hand, or by menaces or threats, unlawfully hold and keep the possession of any lands or tenements, whether the possession of the same were obtained peaceably or otherwise, such person shall be guilty of forcible detainer, and upon conviction thereof, shall be sentenced to pay a fine not exceeding $\$ 500$, or to undergo an imprisonment not exceeding one 
year, or both, or either, at the discretion of the court, and to make restitution of the lands and tenements unlawfully detained as aforesaid: Provided, That no person shall be guilty of forcible detainer, if such person, by himself, or by those under whom he claims, has been in peaceable possession for three years next inmediately preceding such alleged forcible cletention." 1

\section{Must be a Breach of the Peace.}

332. These laws have an important place in considering the rights and remedies of landlords and tenants.

"The general common-law principle is, that though the mere breaking and entering the house of another is not a misdemeanor; yet if that entry is attended by circumstances constituting a breach of the peace, it will become a misdemeanor." $1 *$

" "A mere refusal to deliver possession when demanded will not warrant the process for forcible entry and detainer; but the possession must be attended with such circumstances as might excite terror in the owner, and prevent him from claiming his rights; such as apparent violence offered in deed or word to the person, having unusual offensive weapons, or being attended by a multitude of people." 2

"The force must exceed a bare trespass." "An entry by breaking the doors or windows, etc., whether any person be in the house or not, especially if it be a dwelling-house, is a forcible entry within the statute." 3

A landlord has no right to expel even a tenant at will by force, and he cannot enter with a strong hand to disposses a tenant with force after the expiration of the term; he cannot assert his title with violence. ${ }^{4}$

I P. L. Dig. I203; P. L. 382, §§ 21, 22.

I* Wharton's Criminal Law, § 2014.

2 Wharton's Criminal Law, $\$ 2015$.

3 Wharton's Criminal Law, §2034; I Wharton's Precedents of Indictments, 435, 436; Com. $v$. Rees, 2 Brewster, 564.

4 Wharton's Criminal Law, § 2038. 
The words "with strong hand" mean something more than a common trespass, viz.: the degree of violence amounting to a breach of the peace. A mere entry by an open door or window, or with a key, however procured, or by trick and contrivance will not suffice, nor an entry to which the possessor is induced by threats of destroying his cattle or goods.

\section{Forcible Detainer.}

333. The same circumstances of violence or terror which make any entry forcible will make a detainer forcible also. It was held in England that the offense may be committed by a lessee who forcibly maintains possession when his term has expired. ${ }^{6}$

Prosecutors obtained a lease, and upon attempting to take possession were opposed by defendants, who closed and fastened the gate, and kept them out by main force. It was held that as the prosecutors, although they never had possession, had the right of possession, the defendants were liable for a forcible detainer. ${ }^{7}$

It has been held that a person rightfully entitled to possession of a stall could lawfully require the lessor's agent in possession to leave the stall, and if he should refuse he could use such reasonabe force as would compel him to withdraw from it; that it did not appear that any breach of the peace was committed beyond the defendant's putting his hand to the collar of the agent's coat and walking him away from the stall; that this was done after the agent was required to leave. ${ }^{8}$

\section{Tenant Holder-Over not Liable for Forcible Detainer.}

334. A lessee, permitted to hold over after the expiration of his term, is in no sense a trespasser while he continues in

5 I Wharton's Precedents, 437.

6 Taylor's Landlord and Tenant, 584 .

7 Com. v. Wisner, 8 Phila. 6r2.

8 Com. v. M'Neile, 8 Phila. 438. 
possession, but, on the contrary, he has a clear right to remain upon the demised premises until he is notified to quit. ${ }^{9}$

To Constitute Forcible Entry or Detainer there Must be Violence.

335. One who has leased premises to another is not guilty of the crime of forcible detainer if he refuse to admit the tenant to the premises. A prior possession of the premises by the prosecutor and an unlawful detention of them by the landlord are necessary to sustain a conviction. The indictment must follow the words of the statute "and with strong hand." The words vi et armis are not a sufficient substitute. The same description and degree of force is necessary to constitute a forcible entry as forcible detainer. A prosecution for forcible detainer is not an appropriate remedy for the breach of an agreement to give possession of lands and tenements. ${ }^{10}$

9 Com. v. Knarr, I35 Pa. 35.

ro Com. v. Brown, 28 W. N. C. 149. 


\section{CHAPTER XVIII.}

PROCEEDINGS TO RECOVER POSSESSION OF DEMISED PREMISES AT THE END OF THE TERM UNDER THE ACT OF MARCH 2 I, I772.

SECTION

336. Words of the act.

337. Who are entitled to the benefit of the act.

338. Rent must be certain.

339. Notice to quit.

340. Service of notice to quit.

341. Complaint.

342. Venire to the sheriff.

343. Service of summons.

344. Proceedings before the jury.

345. Proceedings when the title is disputed.
SECTION

346. Finding of the jury, judgment and writ for possession.

347. Proper form for the record.

348. Removal by certiorari.

349. What can be shown at hearing upon certiorari.

350. Appeal to the Supreme Court.

351. Tenant may traverse the inquisition in an action of ejectment.

Words of the Act.

336. "Where any person or persons in this province, having leased or demised any lands or tenements to any person or persons, for a term of one or more years, or at will, paying certain rents, and he or they, or his or their heirs, or assigns, shall be desirous upon the determination of the lease, to have again and repossess his or their estate so demised, and for that purpose shall demand and require his or their lessee or tenant to remove from and leave the same, if the lessee or tenant shall refuse to comply therewith in three months after such request to him made, it shall and may be lawful to and for such lessor or lessors, his or their heirs and assigns to complain thereof to any two justices of the city, town or county, where the demised premises are situate, and 
upon due proof made before the said justices, that the said lessor or lessors had been quietly and peaceably possessed of the lands or tenements so demanded to be delivered up, that he or they demised the same under certain rents to the then tenant in possession, or some person or persons under whom such tenant claims or came into possession, and that the term for which the same was demised is fully ended, that then and in such case it shall and may be lawful for the said two justices to whom complaint shall be made as aforesaid, and they are hereby enjoined and required forthwith to issue their warrant, in nature of a summons, directed to the sheriff of the county, thereby commanding the sheriff to summon twelve substantial freeholders to appear before the said justices within four days next after issuing the said summons, and also to summon the lessee or tenant, or other person claiming or coming into possession under the said lessee or tenant, at the same time to appear before them, the said justices and freeholders, to show cause, if any he has, why restitution of the possession of the demised premises should not be forthwith made to such lessor or lessors, his or their heirs or assigns; and if upon hearing the parties, or in case of the tenant's or other persons claiming or coming into possession under the said lessee or tenant, neglect to appear after being summoned as aforesaid, it shall appear to the said justices and freeholders, that the lessor or lessors had been possessed of the lands or tenements in question, that he or they had demised the same for a term of years, or at will to the person in possession, or some other under whom he or she claims or came into possession at a certain yearly or other rent, and that the term is fully ended, that demand had been made of the lessee or other person in possession as aforesaid, to leave the premises three months before such application to the said justices, that then and in every such case it shall and may be lawful for the said two justices to make a record of such finding by them, the said justices and freeholders, and the said freeholders shall assess such damages as they 
think right against the tenant or other person in possession as aforesaid, for the unjust detention of the demised premises, for which damages and reasonable cost shall be entered by the said justices, which judgment shall be final and conclusive to the parties; and upon which the said justices shall, and they are hereby enjoined and required to issue their warrant under their hands and seals directed to the sheriff of the county, commanding him forthwith to deliver to the lessor or lessors, his or their heirs or assigns, full possession of the demised premises aforesaid, and to levy the costs taxed by the justices, and damages so by the freeholders aforesaid assessed, of the goods and chattels of the lessee or tenant, or other person in possession as aforesaid, any law, custom or usage to the contrary notwithstanding."

\section{Who are Entitled to the Benefit of the Act.}

337. Lessors who have leased for one or more years or at will to tenants paying certain rents, or their heirs or assigns. Where there is a lease for less than a year the lessor may proceed. ${ }^{1}$ An owner of premises leased them and gave notice to the tenant to quit, he afterwards conveyed the premises and his grantee afterwards conveyed them; the last grantees are assignees within the meaning of the act and could recover possession under the act. ${ }^{2}$

The Supreme Court defined the word "lessor" in the act of I 863 to include whoever may succeed to the lessor's title. ${ }^{8}$ Devisees under wills are not named, but it seems that they are assignees within the meaning of the law. A devise in this state is a kind of conveyance or declaration of uses in the lifetime of the testator. On this ground, before the act of assembly to remedy this defect, a will did not pass after acquired property.

Premises were leased, the landlord gave the tenant notice to quit and afterwards conveyed part of the premises; the

I Shaffer $v$. Sutton, 5 Binn. 228; Hollis $v$. Burns, Ioo Pa. 206.

2 Duff $v$. Fitzwater, $54 \mathrm{~Pa}$. 224. 3 Glenn $v$. Thompson, $75 \mathrm{~Pa} .389$. 
grantee at the end of the term proceeded under the act of March 21, 1772 , to recover possession of the part, the lessor not joining nor taking any steps to recover possession of the remainder. Held, that the case was within the act. The court remarked, however, that a landlord cannot proceed for part and hold the tenant for the residue. ${ }^{4}$

\section{Rent Must be Certain.}

338. By the terms of the act this is so. The rent of "taking care of the grain of the landlord on the place, and keeping out the cattle" is not certain. ${ }^{5}$ A demise at will in consideration of services to be rendered annually to a religious society, as for singerand organist, was held not to be for a certain rent. ${ }^{6}$ The act does not apply where there is a lease at will without a reservation of rent. ${ }^{7}$ The words certain rent mean what is ordinarily understood by the expression, and the act applies only to leases in which a certain rent is clearly and distirctly reserved, and not to cases where the rent reserved is so uncertain as to require the intervention of a jury to render it certain. $^{8}$

\section{Notice to Quit.}

339. A notice to quit "at the end of the term" is sufficient; the tenant is bound to take notice of its expiration. It is sufficient to describe the property as in the lease, as the tenant will know what property has been rented. ${ }^{\circ}$ The notice nust be positive, not in the alternative or conditional.

The notice must be given by the person interested in the premises or his agent properly appointed. It should be signed by the landlord himself or by some person in his name who has been authorized by him, and directed to the tenant. As the tenant is to act upon the notice at the time it is given to

4 De Coursey v. Trust Co., 8I Pa. 217.

5 Scott $v$. Fuller, 3 P. \& W. 55.

6 Hohly $v$. Society, 2 Pa. 293.

8 Davis v. Davis, 115 Pa. 26r.

7 Graver $v$. Fehr, 89 Pa. 460.

9 Duff v. Fitzwater, 54 Pa. 224. 
him it should be binding on all parties concerned. The notice to quit may be waived, but such waiver should be stated in all the proceedings.

Where the lease is for a fixed definite period a notice before the expiration of the term is unnecessary; if the tenant do not remove, the landlord may, after the expiration, give notice and proceed under the act. ${ }^{10}$ In case the lease is for a fixed certain term the landlord does not have to wait until the end of the term before serving the notice to quit, he can give notice for possession at the end of term if he has time to give three months' notice before them, but if he has not time he can give notice to quit after the term and upon the expiration of the three months' notice. When the lease is from year to year the notice must be given three months before the expiration of the current year. ${ }^{11}$

\section{Service of Notice to Quit.}

340. The notice had better be served on the tenant personally on the demised premises if possible so as to avoid all questions. Care should be exercised in obtaining and preserving a proof of service of notice.

\section{Complaint.}

34 I. If the tenant should refuse to comply with the notice, the landlord must make a written complaint, with an affidavit before two justices of the peace of the county where the demised premises are, and state:

That he was quietly and peaceably possessed of the demised premises (the premises should be described, located and identified, so that the officer executing the writ of possession will know what property he is to take possession of).

That he demised the same on certain rents to the tenant in possession or to some person under whom he claims or came

Io Logan $v$. Herron, 8 S. \& R. 459.

I B Boggs v. Black, I Binn. 332; Fahnestock v. Faustenauer, 5 S. \& R. I74. 
into possession. [The remarks concerning the complaint under the act of 1863 , are referred to.]

That the term for which the same were demised is fully ended.

That notice to quit had been given three months before the end of a current year, in case of a tenancy from year to year; or three months before making the complaint, in case of a lease for a fixed period.

That the tenant has neglected or refused to comply with the notice.

\section{Venire to the Sheriff.}

342. Upon the proof being made, the justices prepare the summons, directed to the sheriff of the county, and thereby command him to summon twelve substantial freeholders to appear before them within four days after issuing the summons, and also to summon the lessee or tenant, or other person claiming or coming into possession under the tenant, to appear before them, to show cause, if any they have, why restitution of the possession of the demised premises should not be forthwith made to the lessee or his heirs or assigns. The summons should particularly recite the complaint.

\section{Service of Summons.}

343. Theact does not state how the summons is to be served on the defendants.

Leased premises were a theatre, and not a dwelling-house, nor did the defendant live in it, but it was occupied by his agent; and the return of the sheriff showed that he summoned the defendant to appear by leaving a true and attested copy of the writ on the premises with the agent, and making known to him the contents thereof. The court held that the object of the law was, that the service should be made in such manner that the person in actual possession should have notice of the summons. The court called attention to the fact that, at the time of the passage of the act, personal service of 
the ordinary summons was not necessary, and that the sheriff might leave "notice in writing of such summons at the house of the defendant, in the presence of one or more of his family or neighbors, signifying that the defendant should be and appear according to the contents of such summons." The court said : From the language of the act, service on the demised premises upon the person in possession seems to be contemplated; that service on an agent in possession is sufficient. ${ }^{12}$

Personal service on the tenant on the premises or elsewhere will probably be good as a notice to quit for non-payment of rent, under the act of 1830 , will be good served on the defendant off the demised premises. ${ }^{13}$

Under the act of 1863 , the summons must be served upon the defendant personally or at his dwelling-house. If it cannot be served personally, and the defendant has no residence in the county, it may be necessary to proceed under the act of $177^{2}$, by serving a person in possession of the demised premises who holds possession under or by the authority of the tenant.

\section{Proceedings Before the Jury.}

344. Sickness of counsel is a ground for continuance. ${ }^{14}$ When justices of the peace do not allow a reasonable time to the tenant to procure his testimony, the court will set aside the proceedings. ${ }^{15}$ Upon certiorari, ground being laid by affidavit, the court will go into proof of partiality, corruption or extortion. ${ }^{16}$

A description of premises in an inquisition under the act is sufficient, if it is the same as in the lease. If the tenants knew what to take and enjoy by the description in the lease, they knew what to surrender, and if the sheriff has to be called in, he will deliver only the premises which the tenants obtained

I2 Watts $v$. Fox, $64 \mathrm{~Pa}$. 336. I3 Reid $v$. Christy, 2 Phila. I44.

I4 McMullin v. Orr, 8 Phila. 342. I5 Stewart v. Martin, I Yeates, 49.

I6 McMullin $v$. Orr, 8 Phila. 342. 
under the lease. The description in this case held to be sufficient was, "Certain premises, stables, etc., with the appurtenances, situate on the north side of Filbert street above Eighth, in the city of Philadelphia." 17

Where the jurors cannot agree the justices may discharge them, and issue a new precept to the sheriff directing him to summon a new jury. ${ }^{18}$

\section{Proceedings when the Title is Disputed.}

345. "If the tenant shall allege that the title to the premises is disputed and claimed by some other person whom he shall name, in virtue of a right or title accrued or happening since the commencement of the lease by descent, deed or will of the lessor, and if the claimant shall forthwith, or upon a summons immediately to be issued by the justices, returnable in six days next following, before them to appear, and if the claimant on oath or affirmation to be administered by the justices, shall declare that he verily believes that he is entitled to the premises in dispute and shall, with one or more sufficient sureties, become bound by recognizance in the sum of one hundred pounds to the lessor, his heirs and assigns, to prosecute his claim at the next court of common pleas, then the justices shall forbear to give judgment. It being provided, that if the claim shall not be prosecuted, the recognizance shall be forfeited to the use of the lessor, and the justices shall proceed to give judgment and possession to be given under the act of 1772 ." 19

Finding of the Jury, Judgment and Writ for Possession.

346. If the jury shall find the complaint to have been well founded, the record of their finding of these facts is made by the two justices. In that inquisition all the facts should be specifically found and stated, and the jury should assess damages for the unjust detention of the property, for which

17 Duff v. Fitzwater, $54 \mathrm{~Pa}$. 224. $\quad$ I8 White v. Arthur, $24 \mathrm{~Pa} .96$.

19 Act March 21, 1772. 
damages and reasonable costs judgment shall be entered by the nugistrates.

Upon the finding of the jury being entered of record by the magistrates, it is final and conclusive, and the magistrates issue a writ of possession, under their hands and seals, directed to the sheriff, commanding him forthwith to deliver to the lessor full possession and to levy the costs taxed and the damages.

Proper Form for the Record.

347. The Supreme Court, in sustaining a record by Thompson, C. J., said: "The record here follows with the utmost strictness the form given in Binn's Justice in such cases, edition of 1870 , by Brightly, p. 535. That form has been in use for more than a third of a century, and is copied from Graydon, which is much older. Hundreds of records have been made in accordance therewith, and, so far as I know, it has never been condemned by any court." 20

\section{Removal by Certiorari.}

348. Proceedings may be removed by certiorari to the court of common pleas, but the certiorari will not be a supersedeas to the execution.

Not even in the city of Philadelphia, under the act of March 24, $1865 .{ }^{21}$

Neither an affidavit nor a bond is required to support a certiorari to the magistrate under the act of March 2 I, I772. It is a common-law writ. ${ }^{22}$

\section{What Can be Shown at Hearing upon Certiorari.}

349. Upon certiorari only the regularity of the proceedings, as it appears by the record, can be examined. A lease showed that its termination depended upon a contingency,

20 Buchannan $v$. Baxter, $67 \mathrm{~Pa} .348$.

2 I De Coursey $v$. Trust Co., 8r Pa. 2 I7.

22 Veditz $v$. Levy, 17 W. N. C. 477. 
but the record did not show it, and the court could not consider the terms of the lease not part of the record, and it was held to be improper to allow depositions to be read at the hearing. ${ }^{23}$

To establish fraud or want of jurisdiction the court may hear facts by affidavit: but not to show irregularity which would contradict the record. ${ }^{24}$

\section{Appeal to the Supreme Court.}

350. The judgment of the court of common pleas in proceedings by certiorari may be brought before the Supreme Court. The jury before the justices was intended to take the place of a jury in court, but with differences. In case the jury should blunder as to law or facts, or in case the justices should blunder in advising and performing their parts of the proceeding there will be no remedy in the courts, provided the forms conform to the act of assembly. The remedy for informalities is by certiorari. By such a procceding the court of common plẹas can affirm or reverse the proceedings before the justices for informalities, subject to review by the Superior Court, but as to the evidence, law and merits of the case the decision of justices and their jury will be final and conclusive. As the warrant for possession follows immediately after the judgment the law seems to be very favorable to landlords. ${ }^{25}$

\section{Tenant May Traverse the Inquisition in an Action of Ejectment.}

35I. An adverse finding by the jury may be traversed by the tenant in an action of ejectment to try the title. ${ }^{26}$

23 Steamboat Co. v. Hass, I5I Pa. II3.

24 Wistar $v$. Ollis, $77 \mathrm{~Pa} .291$.

25 Clark v. Yeat, 4 Binn. I84; Clark v. Patterson, 6 Binn. I.28.

26 Galbraith v. Black; 4 S. \& R. 206. 


\section{CHAPTER XIX.}

PROCEEDINGS TO RECOVER POSSESSION AT THE END OF THE LEASE UNDER THE ACT OF DECEMBER I4, I863.

SECTION

352. Words of the act.

353. Power of justice of the peace extended to aldermen.

354. Act extended to assignees.

355. Appeal will be a supersedeas in Philadelphia.

356. Tenancy to be established by parol or written agreement.

357. Notice to quit.

358. Tenant not bound to give notice to quit.

359. Notice given by assignec of lease.

360. Verbal notice.

$36 \mathrm{r}$. Time of giving notice.
SECTION

362. No limitation for landlord to proceed on notice.

363. Notice to quit may be waived.

364. Service of notice for possession.

365. Complaint.

366. Summons.

367. Service of summons.

368. Hearing.

369. Warrant for possession.

37o. Appeal.

37 I. Judgment.

372. Record.

373. Certiorari.

374. Appeal to Superior Court.

Words of the Act.

352. "Sec. I.- That when any person, or persons, in this state, having leased or demised any lands, or tenements, to any person, or persons, for a term of one or more years, or at will, shall be desirous, upon the determination of said lease, to have again and repossess such demised premises, having given three months' notice of such intention to his lessee. or tenant, and said lessee or tenant, shall refuse to leave and surrender up said premises, at the expiration of said term, in compliance with the terms of said notice, it shall be lawful for such lessor, his agent, or attorney, to complain thereof, to any justice of the peace, in the city, borough, or county, wherein the demised premises lie, whose duty it shall 
be to summons the defendant to appear at a day fixed, as in other civil actions, and upon due proof being made, the tenant, having notice of the time and place of hearing, that the said lessor was quietly and peaceably possessed of the lands, or tenements, so required to be surrendered $ı p$, and that he demised the same to the tenant in possession, or to some other person, under whom sucl tenant claims, and that the term for which the same were demised, is fully ended and that three months' previous notice had been given of his desire to repossess the same, then, and in that case, if it shall appear right and proper to the said justice, he shall enter judgment against the said tenant, that he forthwith give up the possession of the said premises to the said lessor; and that said justice shall also give judgment in favor of the lessor. and against the lessee or tenant, for sucl clamages as, in his opinion, the said lessor may have sustained, and for all the costs of the proceedings; and he shall forthwith issue his warrant, to any constable in the county, commanding him, immediately, to deliver to the lessor, his agent, or attorney, full possession of the said demised premises, and to levy the damages and costs, awarded and taxed by the said justice. of the goods and chattels of the lessee, or tenant, or other person in possession; any law, custom, or usage to the contrary notwithstanding: Provided, That the defendant may at any time within ten days after the rendition of judgment, appeal to the court of common pleas, in the manner provided in the first section of an act relative to landlords and tenants, approved April 3, r830: And provided further, That such appeal shall not be a supersedeas to the warrant of possession aforesaid. but shall be tried in the same manner as actions of ejectment. and if the jury shall find in favor of the tenant, they shall also assess the damages which he shall have sustained by reason of his removal from the premises; and for the amount found by the jury, judgment shall be rendered in his favor, with costs of suit, and that he recover possession of the premises, and he shall have the necessary writ or writs, of execution to 
enforce said judgment: And provided further, That the tenant may have a writ of certiorari to remove the proceedings of the justice, as in other cases." 1

Power of Justice of the Peace Extended to Aldermen.

353. The powers and jurisdiction conferred upon justices of the peace are conferred upon aldermen, and any one may act with like effect, as may be done by any justice of the peace. ${ }^{1 *}$

Act Extended to Assignees.

354. Act applies to cases in which the owner or owners have acquired title by descent or purchase from the original lessor or lessors. ${ }^{2}$

Appeal will be a Supersedeas in Philadelphia.

355. That part of the act which provides that an appeal shall not be a supersedeas as to a warrant for possession was repealed as to the county of Philadelphia. ${ }^{3}$

Tenancy to be Established by Parol or Written Agreement.

356. The proceedings shall be founded upon a written lease or contract in writing, or on a parol agreement, in and by which the relation of landlord and tenant is established between the parties, and a certain rent is therein reserved. ${ }^{4}$

\section{Notice to Quit.}

357. It must be given three months before the end of the term, and must be to quit at the termination of the lease, not some other date.

If a tenant is bound to give possession at a fixed period, the landlord may, without notice to him, set him out of possession, if it can be done without breach of the peace, or he may bring ejectment if the tenant will not go out, and he

I I P. \& L. Dig. $2650, \S 28$; I863, P. L. (I864) II25.

I* Act of April I I, I866. 2 Act of February 20, 1867.

3 Act of June 25, 1869.

4 Act of March 6, I872. 
may sue him upon his covenant for damages. These were the common-law remedies of the landlord. As an additional remedy the act of 1772 was passed, requiring three months' notice for possession "before the application to the justices." The act of 1863 was an additional remedy, not repealing the act of 1772 . The act of 1863 requires the notice to be given "three months before the expiration of the term." Where the lease is from year to year or for any indefinite period, notice is necessary to terminate the demise. ${ }^{5}$

Where the lease is from year to year, or for any indefinite period, notice is necessary to terminate the demise and this, under the act of 1863 , must be given three months before the expiration of the term. ${ }^{6}$

The notice must be to quit upon the determination of the lease, and not upon some other date. ${ }^{7}$

In giving notice to quit on a certain date it will be well to require possession at the expiration of the lease, to wit, on a certain date. Notice to give possession "at the end of the said term of one year" is sufficient. ${ }^{8}$

A landlord cannot without having given three months' notice, proceed under the act to dispossess a tenant holding from month to month, although the lease contains the tenant's agreement to surrender possession on receiving thirty days' notice. ${ }^{9}$

\section{Tenant Not Bound to Give Notice to Quit.}

358. A tenant is not bound to give his landlord any notice that he intends to remove, unless the lease requires it. ${ }^{10}$

\section{Notice Given by Assignee of Lessor.}

359. When the assignee of a lessor gives notice to quit, or a note requiring the date of the commencement of a tenancy,

5 Rich v. Keyser, 54 Pa. 86. 6 Dumn v. Rothermel, I12 Pa. 272.

7 Borough $v$. Walters, 29 W. N. C. 483.

8 Snyder $v$. Carfrey, 54 Pa. 90.9 Gault $v$. Neal, 6 Phila. 6I.

ro Cook $v$. Neilson, ro Barr, 4I; Brown v. Brightly, 14 W. N. C. 497. 
he must show on the face of the paper his authority for giving the notice.

He must sign as assignee of the lessor or recite the assignment in the notice. If, however, the tenant knew or was told of the assignment at the time of the notice, it would be good. ${ }^{11}$

Verbal Notice.

360. A verbal notice to quit is sufficient; and if it be written, a mistake may be corrected at the time of service. ${ }^{12}$

\section{Time of Giving Notice.}

361. Property was leased for one year from March 25, 1868. On December 25, 1868, notice was given, under the act of 1863 , to quit at the end of the term. The lease commenced on March 25, and the last day of the lease was March 24, 1869. March 24 counted a whole day when its last moment had arrived. Counting December 25, on which the notice was given, and March 24, when the lease expired, there was three months' notice before the end of the term. December 25 is to be counted, for the law takes no notice of the fraction of a day in the computation of time. Service on that day was one day's notice. It was held that the notice was measured by the terms of the act itself. ${ }^{13}$

No Limitation for Landlord to Proceed on Notice.

362. After a notice to quit is given, there is no limitation as to the time when the landlord may commence proceedings for possession. The right runs on, unless it is waived. ${ }^{14}$

\section{Notice to Quit may be Waired.}

363. A three months' notice to quit under the act of 1772

II Donaldson v. Likens, 2 Brewster, 486.

12 Tham $v$. Hamberg, 2 Brewster, 528; Koenig v. Bauer, I Brewster, 304.

13 Duffy $v$. Ogden, $64 \mathrm{~Pa} .240$.

I4 Boggs v. Black, I Binney, 332. 
may be waived in the lease, as when the tenant agrees to quit "without further notice." 15

A lease was made to James Glenn and Charles A. Glenn, but a notice to quit was directed to James Glenn \& Son, and was only served on James Glenn; and it was held that a notice to one of two joint lessees is good, and that the verbal mistake in the recital of the names is immaterial. ${ }^{16}$

\section{Service of Notice for Possession.}

364. The acts of March 21, I772, December 14, I863, April 3, I830, February 28, I865, and March 26, I825, to enable tenants to obtain possession of demised premises, require notices for possession to be given by landlords. These acts do not state how such notices are to be given. It is remarkable that there are but few decisions as to the manner of service. According to the common law of England it was necessary to give notice to terminate leases of uncertain duration, and by the drift of our decisions it seems that the notices under our acts can be given in the same way as at common law. Under the act of $I 772$ it has been the practice to leave the notice at the dwelling-house of the tenant. ${ }^{17}$ In a case under the act of 1863 , there was evidence to show that a written notice to quit was pushed under the defendant's door when absent to evade the service; that on his return he entered by the same door; and that the next day the plaintiff told him of the written notice, and the Supreme Court held that such service was sufficient. ${ }^{18}$ Under the act of 1830 , it was decided by the court below that the notice must be served on the party in actual possession at the time, in order to deprive him of his estate. That a sub-lessee cannot be turned out of his possession under the act of 1830 without notice, for he may be willing to pay the rent; but the Supreme Court did not consider the questions.

15 Hutchinson v. Potter, II Pa. 472.

16 Glenn $v$. Thompson, $75 \mathrm{~Pa} .389$.

17 Griffiths $v$. Marsh, 4 T. R. 465.

I8 Currier v. Grebe, I42 Pa. 48. 
In a court of common pleas it was objected that a notice under the act of 1830 did not appear to have been served upon the premises, but the objection was not sustained. ${ }^{19}$ In the case of the lease of a theatre, it was held that leaving a notice with the lessee's agent at the theatre was sufficient. These few authorities appear to be about all the light we can get from the Pennsylvania authorities.

It seems that resort may be had to the English authorities as to service of notices to quit for possession. According to the English practice, service of notice upon the tenant will be good, if given personally, if served upon the actual occupiers, if given to the assignee of the lessee, if delivered to the wife or a servant of the lessee at his dwelling-house (when delivered to a servant or agent it should be expressly said that the notice is to the lessee to quit), if the notice is sent by mail, addressed to the landlord or his authorized agent. ${ }^{20}$

The best course would seem to be to serve the lessee personally on the demised premises. If this cannot be done, then serve a notice at the demised premises on the lessee's wife or servant, if a dwelling-house, but if a place of business then on the principal person having charge thereof, and for an extra precaution serve a notice also on the lessee or his assignee, if recognized, personally. If the lessee or the assignee is away from the city or place in which the demised premises are located, as an extra precaution send him a notice by registered letter and preserve the proof of mailing. In case a notice to quit is given under the act of 1830 for nonpayment of rent, notice had better be given also to all the under-tenants, so that they will have an opportunity to pay the rent in arrear.

Depositing a letter, properly addressed, with the postage prepaid is prima facie evidence that the person to whom it is addressed received it. Evidence that a letter was so sent,

19 Reid v. Christy, 2 Phila. 144.

20 I Addison on Contracts (8th ed.), *275. 
demanding payment of rent, is competent to rebut the allegation that no demand had been made; $;^{21}$ and it seems that this authority will apply to all notices given by landlords to tenants. As the presumption, however, may possibly be overcome by the tenant testifying that he did not receive the letter, it will be best to use also other methods of service. A registered letter, however, had better be sent.

\section{Complaint.}

365. In case the tenant shall refuse to comply with such notice, the persons entitled to the benefit of the act, or their agent or attorney, may complain thereof to any justice of the peace in the county where the demised premises lie. In Philadelphia county the complaint can be made to one of the magistrates.

The complaint should show: first, that the lessor was quietly and peaceably possessed of the demised premises; second, that he demised the same to the tenant in possession for a certain term and rent therein stated, by a written lease or on parol agreement, in and by which the relation of landlord and tenant is established between the parties and by which said rent is reserved; that the term for which the premises are demised is fully ended; that three months' notice of the owner's desire to repossess the premises has been given by him, previous to the end of the term or current year, and that the tenant in possession has neglected or refused to comply with the notice to quit the premises. In case the present owner claims by deed from the original landlord, the complaint should show that on a certain date, by a deed of conveyance, duly made and executed, bearing date the same day and year, for the consideration therein mentioned, the original lessor did grant and convey the demised premises unto the present owner (and his heirs), who declares that he makes the complaint as such grantee. 
In case the landlord has died intestate, it will be well to state that he died on a certain date, intestate, seized in fee of the demised premises, and that the complainant is solely entitled to the same under the intestate law of the state of Pennsylvania. In case of a devise by will or obtaining title otherwise, there should be statements in the papers accordingly.

\section{Summons.}

366. Upon the complaint being made, the magistrate prepares the summons. This summons should contain a recital of all the statements of the complaint.

\section{Service of Summons.}

367. It must be served as in a personal action, on the tenant personally or by leaving a copy thereof at his dwellinghouse, and making known to an adult member of the family the contents thereof. A service of summons personally on defendant at his dwelling-house by leaving a copy of the original summons and making known the contents is a sufficient service. ${ }^{22}$

\section{Hearing.}

368. If it shall appear right and proper to the justice, he enters judgment against the tenant, that he forthwith give up the possession of the premises to the lessor or present owner; and he shall also give judgment in favor of the lessor or present owner and against the lessee or tenant for such damages as, in his opinion, the lessor may have sustained, and for all the costs of the proceedings.

The act of Dec. I4, I863, gives to a single justice the jurisdiction exercised by two justices and twelve freeholders under the act of March 21, I 772.

Under the act of 1863 , the justice must hear any defence the tenant may offer. The appeal under the act of 1863 is in 
place of the provisions of $\S \mathrm{I} 3$ of the act of 1772 , for withdrawing the proceedings from the justices and freeholders upon the assertion by a third party of a title adverse to the lessee's ; and of the act of March 20, I8ro, excluding a justice's jurisdiction when the title to land may come in question. A tenant before a justice or in court on appeal, may set up any defence of which he could avail himself in ejectment by his lessor. The scope of an inquiry into the rights of landlords is no narrower than that into the rights of tenants..$^{23}$

Warrant for Possession.

369. Upon judgment being entered, a warrant can be issued to any constable in the county for obtaining possession of the premises and to levy the damages and costs of the goods and chattels of the lessee or tenant or other person in possession.

\section{Appeal.}

370. The defendant may, at any time within ten days after the rendition of the judgment, appeal to the court of common pleas in the manner provided in the first section of the act relative to landlords and tenants, approved April 3, 1830; but such appeal shall not be a supersedeas to the warrant of possession, and the appeal shall be tried in the same manner as are tried actions of ejectment; and if the jury shall find in favor of the tenant, they shall also assess the damages which he shall have sustained by reason of his removal from the premises and for the amount found by the jury, judgment shall be rendered in his favor, with costs of suit, that he recover possession of the premises; and he shall have the necessary writ or writs of execution to enforce the judgment. The tenant may have a writ of certiorari to remove the proceedings of the justice as in other cases.

23. Quinn $v$. MeCarty, 8і Pa. 475: Heritage $v$. Wilfong, 58 Pa. I37; Mohan v. Butler, II2 Pa. 590. 
The act of June 25, 1869, provides that the appeal shall be a supersedeas of the warrant of possession in the city of Philadelphia, notwithstanding the terms of the act of 1863 .

Judgment.

37. The judgment should include all rent that has accrued up to the time of the rendition of the judgment. ${ }^{24}$ The facts found by the justice must appear in the record of the judgment or by reference to the complaint, if fully set forth therein. The record must contain every essential to support his judgment. Nothing which ought to appear can be taken by intendment. ${ }^{25}$

Premises were not sufficiently described. There were boundaries given of the land, but the acres were in blank, with the addition of the words, "more or less." In this case the lease was said to be for a year or at will. One or other should have been stated. ${ }^{26}$

\section{Record.}

372. The record of the justice or magistrate should record the proceedings and should particularly find the facts stated in the complaint, using, as far as possible, the words of the act of assembly and its amendments.

\section{Certiorari.}

373. The tenant may have a writ of certiorari. Upon a certiorari the evidence is not brought up. The regularity of the proceedings only is examined. It does not supersede or stay the proceedings except in the city of Philadelphia, as aforesaid. The writ of certiorari must be issued within twenty days, or in Philadelphia, under the act of 1865 , within ten days after the judgment is entered.

24 Dunmire \%. Price, 12 W. N. C. 179.

25 Givens v. Miller, $62 \mathrm{~Pa}$. 133; Davis v. Davis, Ir5 Pa. 26r.

26 Givens v. Miller, $62 \mathrm{~Pa}$. I33. 
Appeal to Superior Court.

374. An appeal to the Superior Court from the judgment of the court of common pleas can be taken; but such appeal to the Superior Court will not be a supersedeas to the writ of possession when the judgment shall be against the party at whose instance the writ of certiorari was issued. 


\section{CHAPTER XX.}

PROCEEDINGS TO RECOVER POSSESSION IN PHILADELPHIA ON A LOST LEASE.

SECTION

375. Act of February 28, 1865.

Act of February 28, 1865.

375. "In all cases, in the city of Philadelphia, where there is a lease or verbal letting of property for a term of years or from year to year, and the landlord, whether the owner at the time of such lease or letting or by purchase subsequent thereto, has lost the lease or evidence of the beginning and conclusion of the term or cannot produce proof of the same, it shall be lawful at any time after the first year or after the term of years, as the case may be, for the landlord desiring to recover possession of the demised property, to give notice in writing to the tenant that he has lost such lease or is unable to make such proof, and requiring the tenant, within thirty days from the time of service of such notice, to furnish him, in writing, with the date at which his term of tenancy commenced, and such notice, if supported by affidavit, shall be evidence of what it sets forth. If the tenant shall furnish, in writing, the date as required, such writing shall be evidence of the facts contained in it; but if the tenant shall fail or refuse, within thirty days, to comply with the said requirement, the landlord may, at the expiration of that period, give to the tenant three months' notice to quit the premises occupied by him, and so shall proceed thereafter in the same manner as is now provided in case of the usual notice to quit at the end of the term. Providing, That if the tenant shall 
make affidavit within the thirty days aforesaid, that he is unable to comply with the requirement of the landlord, stating the causes of such inability, the landlord shall give six months' notice to the tenant to remove from the demised premises upon which he shall proceed as provided in cases of the three months' notice as aforesaid." 1

I I P. \& L. Dig. $2654 ;$ 1865, P. L. 253 , § I. 


\section{CHAPTER XXI.}

\section{NEGLIGENCE AS TO RENTED PROPERTY.}

SECTION

376. Defects before renting.

377. Where property rented is unfit for use.

378. Landlord employing plumber.

379. Liability of owners.

380. Landlord and tenant may both be liable.

$38 \mathrm{I}$. Liability in case of an open grate.

382. Landlord and tenant may sue at same time.

383. Where landlord interferes with tenant.

384. Where tenant injures property.

385. Liability between tenants.
SECTION

386. Liability depending upon obligation to repair.

387. Remedy in case tenant commits waste.

388. Act of 1822 as a remedy for waste.

389. Order to permit inspection of waste.

390. Writ of estrepenent.

39I. Remedy by suit for waste.

392. Remedy by an injunction for waste.

393. Liability of contractor for injury.

394. Liability for leakage from a cess-pool.

395. Liability for not repairing sidewalk.

\section{Defects Before Renting.}

376. When a person rents a property to another, he is liable for defects thereof; he is liable for defects which exist when he parts with its control. ${ }^{1}$

Where Property Rented is Unfit for Use.

377. One who erects a building for rent is bound to use reasonable skill and diligence in its erection, regard being had to the uses and purposes for which it is designed. If a landlord rents a house unfitted for the purpose of the tenant, as for heavy storage, he must forbid such use in the lease, or

I Redfield on Negligence, $\S 502$. 
he will be liable to a stranger for damages. ${ }^{2}$ In Curtin $v$. Somerset, I4O Pa. jo, the Supreme Court remarked that in Godley $v$. Hagerty, the builder was the owner and that in Carson $v$. Godley, the warehouse was erected under the personal superintendence of the owner. ${ }^{3}$

\section{Landlord Employing Plumber.}

378. It has been held that a landiord who employs a plumber to construct a water-closet in the upper story of a house, is not responsible for damages resulting from the improper construction of the water-tank to the tenant of the premises, it not being shown that the plumber selected was not a competent workman. That as the injury arose not from the water-closet, which was a lawful and useful construction in itself, but from want of skill in the construction of it, the landlord was not liable. ${ }^{4}$ Plumbing work is a part of the real estate and for defects thereof the owner of the house is presumptively responsible. If the landlord provides pipes and other plumbing work of good quality, the tenant only is responsible for the mode in which these accommodations are used, and for any overflow caused either by neglect to turn off the water, or by such misuse of the works as deprives them of power to stop the flow of water. ${ }^{5}$

\section{Liability of Owners.}

379. When an owner has done all in his power to erect a safe structure, he is not liable to others for its occult defects, if he had not knowledge of them nor reason to believe their existence. A warehouse fell and destroyed barrels of whisky and the plaintiff claimed that the house had been negligently built by defendants and there was a verdict for the defendants. ${ }^{6}$

2 Godley v. Hagerty, $20 \mathrm{~Pa} .387$; Carson v. Godley, $26 \mathrm{~Pa}$. III.

3 Curtin v. Somerset, $140 \mathrm{~Pa} .70$.

4 Meany $v$. Abbott, 6 Phila. 256.

5 Redfield on Negligence, $\S 513$.

6 Walden $\approx$. Finch, $70 \mathrm{~Pa} .460$. 
Iandlord and Tenant may both be Liable.

380. The landlord and tenant may be liable for the same injury - the former for negligent construction, and the latter for negligent use of the premises. A landlord is not liable for a nuisance erected by his tenant after the renting, nor in the absence of a covenant in the lease for the consequences of the natural decay of the premises, as where fences are suffered by the tenant to fall into decay, whereby a stranger's cattle stray and are injured. ${ }^{7}$

\section{Liability in Case of an Open Grate.}

$38 \mathrm{I}$. There was a vault under the sidewalk on the public street in front of the premises, into which there was an opening, covered by a grate. One of the bars of the grate was broken during the term, and by reason thereof a person was injured and it was held that the tenant was liable, but not the landlord; for it was shown that the premises were in good repair when demised, and it did not appear that the landlord was bound to repair. ${ }^{8}$

\section{Iandlord and Tenant may sue at Same Time.}

382. A tenant and landlord may both maintain actions at the same time for injury done to the estate; the former for the interruption of his possession and diminution of his profits, the latter for the permanent injury to his property. ${ }^{9}$

\section{Where Landlord Interferes with Tenant.}

383. A tenant may sue the landlord for any interference with the leased premises, in violation of the lease. ${ }^{10}$

\section{Where Tenant Injures Property.}

384. A landlord may sue the tenant for an injury to the demised premises. ${ }^{11}$

7 Redfield on Negligence. $\$ 56$.

92 Hilliard on Torts, 584.

8 Bears $v$. Ambler, 9 Pa. 193.

I 2 Hilliard on Torts, 589. I0 2 Hilliard on Torts, $\mathbf{5 8 4}$. 
Liability Between Tenants.

385. As between different tenants under a common landlord, the question of liability from the condition of the premises is always one of negligence in the use of premises. ${ }^{12}$

Liability Depending upon Obligation to Repair.

386. If a landlord agrees to repair, he will be liable to a third person for the want of the repairs. ${ }^{13}$

\section{Remedy in Case Tenant Commits Waste.}

387. Waste as respects tenants is the spoil or destruction done or permitted to lands, houses or other corporeal hereditaments by the tenant thereof, to the prejudice of the heir or of him in reversion or remainder. Waste may be permissive or active or voluntary. If a tenant should permit buildings to go to ruin for the want of tenantable repairs, that would be permissive waste; if he should injure buildings, that would be voluntary waste, other cases of voluntary waste would be in case a tenant should not cultivate farm land according to usual course of husbandry or when he should open and work new mines.

\section{Act of 1822 as a Remedy for Waste.}

388. It is provided that it shall and may be lawful for any owner or owners of any lands or tenements, leased or let for years or at will, at any time during the continuance or after the expiration of such demise, and due notice given to the tenant or tenants to leave the same, according to the provisions of the act of assembly in such case made and provided, to apply to the court of common pleas of the proper county while in session, or to any judge thereof, in vacation, by petition and affidavit made by him, her or them, or some credible person, setting forth such of the facts before mentioned as may be necessary to 
bring him, her or them within the provisions of the act and that the tenant or person in possession has committed waste to the freehold (or allow it to be done by others), or threatens to do the same, and that such owner or some other person for him or them, verily apprehends, in consequence of such threat, that such waste will be committed, unless the same be restrained by law, it shall be lawful for the court or judge to order a writ of estrepement to stay waste. A motion my be made to dissolve the writ. ${ }^{14}$ The writ cannot be issued without security being given to indemnify the respondent as in case of the issuing of preliminary injunctions. ${ }^{15}$

\section{Order to Permit Inspection of Waste.}

389. After the issuing of a writ of estrepement the court will make an order for the inspection of the premises to ascertain whether waste has been committed since the service of the writ. ${ }^{16}$

\section{Writ of Estrepement.}

390. Valuable forms in proceedings for waste appear in Richards' Pennsylvania Form Book, under the subject, "Estrcpement" (see, also, his comments). The writ contains a command to the sheriff to prohibit and restrain the defendant from committing waste and also a command to the defendant not to commit waste. By virtue of the writ the sheriff may resist those who commit waste or offer to do so; and he may use sufficient force for the purpose. At common law if the writ is directed and delivered to the tenant and he commits waste, the court could imprison for contempt. ${ }^{17}$

\section{Remedy by Suit for Waste.}

391. If a tenant injures the landlord's house or lands the landlord can sue for damages. 
Remedy by an Injunction for Waste.

392. The equity jurisdiction of courts was extended to the prevention or restraint of the commission or continuance of acts contrary to law and prejudicial to the interests of the community, or the rights of individuals, and, consequently, waste being an act contrary to law, an injunction will be granted. ${ }^{18}$

Liability of Contractor for Injury.

393. Where a contractor for cleaning a well in an outhouse removed some boards in the course of his work which were replaced on the roof without being fastened and thirteen months after the work was done and the contractor was paid by the landlord, a member of the family of the tenant of the premises was injured by one of the boards falling upon her. It was held that the contractor was not liable for such injuries. That if the contractor had failed to fully perform his contract, he would be responsible to the landlord with whom he contracted for any breach; but he owed no duty to a stranger for such non-performance, much less to one who was injured more than a year after the work was done. The contractor's work having been accepted by the landlord, he owed no duty to persons who should afterwards use the well; and the landlord not being bound to replace the boards unless under a covenant to repair; it was the duty of the tenant of the premises to secure the boards if they were dangerous, or to see that they were made secure by the one whose duty it was to do so. $^{19}$

Liability for Leakage from a Cess-pool.

394. It was held that if a cess-pool was not improperly near a neighbor's dwelling, was properly constructed and was in good repair when the tenant took possession, the

I.8 Act June I6, I836; I P. \& L. Dig. 7 10; I836, P. L. 784 , § I3.

I9 Fitzmaurice v. Fabian, 29 W. N. C. 339; Curtin v. Somerset, I40 Pa. 70 . 
landlord was not responsible for injuries to a neighbor from leakage. The tenant who used the defective cess-pool would be liable because of its use. The court did not place the liability of the tenant upon his liability to repair. It seems that if the leakage could have been stopped by an ordinary repair the tenant would also be liable on that ground. ${ }^{20}$

\section{Liability for Not Repairing Sidewalk.}

395. It is the duty of property owners on a street to keep in proper repair the sidewalk along their respective residences, and if they fail to do so they will be liable for any injury resulting therefrom. An owner of property in the actual possession of a tenant is liable for injuries caused by defects in the sidewalk on the public streets, along his property, even though he had no notice to repair the same. Owing to this primary liability after recovering from the municipality, the latter can recover from the property owner. ${ }^{21}$

20 Wander $v$. McLean, I34 Pa. 334.

2I Mintzer v. Hogg, I92 $\mathrm{Pa}$. 137. 


\section{CHAPTER XXII.}

RIGHTS OF LANDLORDS AND TENANTS IN CASE RENTED PROPERTY IS TAKEN FOR PUBLIC USE.

SECTION

396. Constitutional provision.

397. Difference when state takes.

398. Damages awarded to landlords and tenants.

399. Party wall condemned and taken down by public authority.

400. Tenant can recover damages to building erected before ordinance for removal.
SECTION

40I. Landlords and tenants may unite to recover damages for taking property for public use.

402. Land may be cultivated until possession taken.

403. Effect of taking on liability for rent.

404. What damages can be recovered.

\section{Constitutional Provision.}

396. The constitution of the state of Pennsylvania provides that: "Municipal and other corporations and individuals invested with the privilege of taking private property for public use, shall make just compensation for property taken, injured or destroyed by the construction or enlargement of their works, highways and improvements, which compensation shall be paid or secured before such taking, injury or destruction. The general assembly is hereby prohibited from depriving any person of an appeal from any preliminary assessment of damages against any such corporation or individuals, made by viewers or otherwise; and the amount of such damages, in all cases of appeal, shall, on the demand of either party, be determined by a jury, according to the course of the common law."

\section{Difference when State Takes.}

397. When the commonwealth exercises the power of 176 
eminent domain, it must provide the means of payment before taking the property; but a corporation or individual must pay or secure its price. ${ }^{1}$

\section{Damages Awarded to Landlords and Tenants.}

398. When land is appropriated by the sovereign, the landlord is entitled only to the present value of his reversion, or the property subject to the term of the lease, and the tenant, being personally bound, is entitled to the value of his term, subject to the rent and so much besides as will indemnify him for the rent payable in the future; but a chancellor would regard the damages awarded to the tenant to indemnify him against his covenant to pay rent as in equity the money of the landlord, and decree it paid to him; a jury of view to assess damages ought at once to award it to him. The inevitable consequence of such award is to release the tenant from his personal obligation. The landlord receives his full loss, the value of the rent and the reversion-what the land, subject to the term, would be worth to a purchaser of the reversion, who would, of course, be entitled to the rent as incident to it. The tenant receives his full loss, the value of his term, subject to the rent; what it would be worth to an assignee who would assume the payment of the rent. If the rent is the full value of the premises he has lost nothing, and is entitled to receive nothing. If he has paid a consideration for the term, and has it at a pepper-corn or nominal rent, he is entitled to recover what such a lease is worth. ${ }^{2}$

\section{Party Wall Condemned and Taken Down by Public Authority.}

399. The owner of an adjoining lot caused a party-wall to be condemned, whereby he was authorized to remove the same. In taking it down the tenant's house was exposed. Held, not a defence to a claim for payment of rent. ${ }^{3}$

I McClinton v. Railroad Co., 66 Pa. 404; Railroad Co. v'. Railroad Co., I4I Pa. 407.

2 Dyer $v$. Wightman, $66 \mathrm{~Pa} .425$.

3 Wilson $v$. Barns, 17 W. N. C. 27. 


\section{Tenant can Recover Damages to Building Erected before Ordinance for Removal.}

400. A tenant who has leased a building after the passage of an ordinance providing for the widening of the street upon which the building is situate, is entitled to recover damages for the injury caused by the demolition and re-erection of the front of the building which had been erected before the enactment of the ordinance. An ordinance for the widening of a street was subsequent to the date of the plaintiff's lease. Held, that the tenant could recover damages for actual injury from dirt and grime, which were necessarily encountered, and which injured his stock. He could not recover for loss of profits in business. ${ }^{4}$

Landlords and Tenants may Unite to Recover Damages for Taking Property for Public Use.

40I. The landlords and tenants of properties taken and injured by railroad corporations may unite in a proceeding to recover damages for such taking or injury. The jury should ascertain the aggregate amount of damages sustained and designate the proportion to which each of the parties interested is entitled. In estimating the damages payable to the tenant it is proper for the jury to consider as elements of damage the facts that the location of the railroad compelled the removal of the business conducted by the tenant, and the depreciation in value of the leasehold, and also of the machinery and personal property of the tenant used in the business consequent upon such removal. ${ }^{5}$

Land may be Cultivated until Possession Taken.

402. A land owner may continue in the cultivation of his land after the location of a railroad upon it, until actual entry by the company, and may recover compensation not only for injuries to the land but for the loss of growing crops planted

4 Justice v. Phila., 169 Pa. 503; Shaw v. Phila., I69 Pa. 506.

5 Getz v. Railroad Co., to5 $\mathrm{Pa} .547$. 
before a bond given or notice to enter for construction. So a tenant to whom the land is demised after the location of the line and the notice thereof may recover for all his growing crops destroyed by the construction, which were planted before he had notice of the time when his possession would be interfered with by the company. ${ }^{6}$

\section{Effect of Taking on Liability for Rent.}

403. Where under the right of eminent domain a lease is wholly destroyed, the tenant is relieved from the payment of any further rent although the term of the lease may not have expired; but where there is but a partial destruction the lessee is liable for the rent for the residue of the term and he must look to the state or her grantee for compensation for any injury he may have sustained. ${ }^{7}$

What Damages can be Recovered.

404. Tenants were under a contract to remove daily from the city gas works a large quantity of tar and the premises which they leased enabled them to receive the tar without cost and to manufacture it without transporting it to and from distant points, and in a proceeding to recover damages for the taking of the leasehold premises by a railroad company it was held proper to admit evidence that after the land was taken it became necessary to carry the tar to the place of distillation by a boat specially constructed; that it was necessary to erect temporary works for distillation of tar when received and that it was necessary to haul over inaccessible roads the barrels needed to hold the tar and its product. ${ }^{8}$

6 Lafferty $v$. Railroad Co., I24 Pa. 297.

7 Rap $v$. Klair, 5 Mont. 16.

8 Ehret $v$. R. R. Co., 15I Pa. 158. 


\section{CHAPTER XXIII.}

FEES OF CONSTABLES, JUSTICES OF THE PEACE AND WATCHMEN IN LANDLORD AND TENANT PROCEEDINGS.

SECTION

405. The act of Feb. 17,1899 , relating to fees of constables. $405^{*}$. The act of May 23, I893, re-
SECTION

lating to the fees of justices and magistrates.

406. No provision in the act of I 899 for watchman.

The Act of Feb. 17, 1899, relating to Fees of Constables.

405. The act of May 23, I893, ${ }^{1}$ provided for fees of constables in Pennsylvania. The intention of the act was to make the fees uniform throughout the state. The act provided that all inconsistent acts or parts of acts were repealed. By the act of Feb. 17, I899, ${ }^{*}$ the fees of constables are fixed nearly the same as under the act of 1893 , as follows:

For executing landlords' warrant, ......\$\$ 50

For taking inventory of goods (each item), .. .02

For distraining goods, ............ .50

For selling the same, for each dollar (not exceeding one hundred dollars), ........ .03

For each dollar above one hundred dollars, . $\quad .02$

For advertising the same,.......... I.00

For copy of vendue paper when demanded

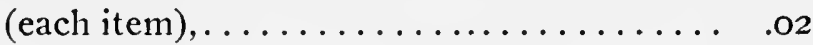

For putting up notice of distress at mansion house, or at any other place on the premises, ........................ .25

For executing a writ of possession, . . . . 2.00 For executing writ of restitution, . . . . . 2.00

I I P. \& L. Dig. 2064; I893. P. L. II7, § 2. I* P. L. I 899, p. 3. 180 
For serving summons in landlord and tenant proceedings, .................. \$o. 50

For serving summons notices on tenant,.... .50

Constable and appraisers, personally, each one dollar on appraisement,.......... 1.00

The Act of May 23, 1893, Relating to the Fees of Justices and Magistrates.

$405 *$. By the act of May 23, I893, ${ }^{2}$ the fees of justices and magistrates throughout the state in landlord and tenant proceedings are as follows:

Holding inquisition under landlord and tenant act, each day, each justice,......\$2.00

Process, et cetera, to sheriff, each justice,... . 75

Recording proceedings, each justice,...... I.50

Writ of restitution, each justice, ........ .75

Fees in landlord and tenant proceedings under act of 1830 are:

Entering complaint, ...........\$0.25

Issuing process,................ .25

Hearing and determining case, ........ .50

Record of proceedings,............. 50

Writ of possession (and return),........ 50

When more than one magistrate is required in landlord and tenant proceedings the above fees shall be charged by each magistrate.

Fees in landlord and tenant proceedings under act of 1863 are:

Entering complaint,............\$o.75

Issuing process, . . . . . . . . .

Hearing and determining case, . . . . . I.00

Record of proceedings,........... I.50

Issuing writ of restitution (and return), . . . I.00

2 I P. \& L. Dig. 2057 ; 1893, P. \& L. 117, § I. 
No Provision in the Act of 1899 for Watchman.

406. Under the act of 1872 the fees for watchmen in Philadelphia county were fixed at the rate of $\$ 3.00$ per day. The act of 1893 did not provide and the act of 1899 does not provide for the fees of watchmen, and it may possibly be held that in Philadelphia they will still be entitled to their fees under the act of 1872 . 


\title{
CHAPTER XXIV.
}

\author{
MINING LEASES.
}

PAGE 184.

SECTION

407. Mining leases in Pennsylvania.

408. Mining right distinct from surface right.

409. Rights of tenant for life.

4I0. Rights of guardians to lease.

4II. Tenant bound to work mine.

4I2. Clause for re-entry necessary.

4I3. Incidental rights of mining tenant.

4I4. Right of support.

415. Loss of springs on surface.

416. Tenant cannot open mines.

417. Rent to be paid, though no clay be taken out, not damages.

418. No warranty of coal.

419. Relief in case of mistake.

420. Tenants taking partners.

42I. Forfeiture for not developing favored.

422. Manner of conveying in case of sales of minerals.

423. Questions as to whetlier there is a salc, a lease or right to take coal without a sale.

424. Mining by tenants in common.

425. Oil and gas leases.

426. Right to mine for oil or gas is necessarily exclusive of
SECTION

the right of the landlord to mine.

427. Liability to pay compensation in case of exhaustion of mines.

428. Obligation to drill through land worthless for oil or gas.

429. Mortgages of mineral leaseholds.

430. Perpetual lease of ore lands.

431. Options to drill or to pay rent.

432. Provisions for the forfeiture of an oil or gas lease for the benefit of the lessor only.

433. Right of mining tenants to pollute streams.

434. Liability for manufacturing coke and injuring crops, etc., of adjoining premises.

435. As to whether or not a mining lease has been forfeited for not operating.

436. Rights to make openings to reach coal.

437. Agreements for diligence in drilling and working for oil, etc.

438. In agreements for coal leases time is of the essence of the contract. 
SECTION

439. Relief against forfeiture of an oil and gas lease for nonpayment of rent.

440. Partnership in mineral leaseholds.

44I. Relief against forfeiture of mining leases.

442. A lease for exploration for oil ceases when exploration finished.

443. Interest on royalties.

444. Tenant will not be compelled in equity to test land for oil or gas if there is no fraud.

445. Covenants to pay royalties run with the land.
SECTION

446. When lessee to follow his own judgment in sinking additional wells.

447. The meaning of the phrase, "to continue so long as oil or gas are produced in paying quantities."

448. Necessity for having oil leases recorded.

449. Jurisdiction in equity for account of gas, etc.

450. Rent may be payable in oil or gas.

45I. Liability of assignee of an oil or gas lease for the payment of royalties.

\section{Mining Leases in Pennsylvania.}

407. It is customary in Pennsylvania to lease lands for the mining of coal and other minerals, and for the obtaining of coal oil and gas. By such leases it is generally arranged that the tenant is required to mine or drill and to pay the landlord a certain proportion of the products of the mining or drilling, usually called royalties. Such leases are generally for a term of years, or for so long as ore, oil, gas, etc., can be obtained in paying quantities.

\section{Mining Right Distinct from Surface Right.}

408. A right to dig for minerals is essentially different from a right to the soil. Nothing is more common in every part of the state where coal or iron abounds than a right to dig for it below the surface of the ground, separated from a right to the surface itself. A grant of it conveys no more than a license to take and appropriate the minerals beneath; and it vests no property in them until they are taken and appropriated. ${ }^{1}$

I Brandt $v$. McKeever, I8 Pa. 70; Grubb v. Grubb, 74 Pa. 25. 
Rights of Tenant for Life.

409. A tenant for life or his grantees may work open mines to exhaustion. ${ }^{2}$

\section{Right of Guardians to Lease.}

4IO. A guardian has ordinarily power to lease any of his ward's property of such character as makes it the subject of a lease; but without the approval of the orphans' court he cannot dispose of any part of the realty. Oil is a mineral, and being a mineral is part of the realty; and a guardian cannot lease the same, as it would in effect be the grant of the corpus of the estate of his ward. ${ }^{3}$ This doctrine may possibly be held to extend to any trustee who is bound to preserve the corpus or principal of an estate intact.

\section{Tenant Bound to Work Mine.}

4I I. A tenant of a mine is bound to work the same in a proper manner and with reasonable diligence, so that the lessor may receive the compensation or income contemplated. Damages can be recovered for failure to do so.*

\section{Clause for Re-entry Necessary.}

412. Clauses of re-entry belong to all mining leases from the necessity of the case. Mining exhausts the land itself, and if the landlord has no clause of re-entry for non-payment of rent he may lose not only his rent, but that part of his land which has been exhausted by the extraction of minerals. It is not waste for a tenant to mine and not pay his rent. ${ }^{5}$

\section{Incidental Rights of Mining Tenant.}

4I3. A lease which gives the right to take out all the coal beneath a certain surface confers also the right to make all

2 Irwin $v$. Covode, $24 \mathrm{~Pa} .162$.

3 Stoughton's Ap., $88 \mathrm{~Pa} .198$.

4 Koch's Ap., 93 Pa. 434.

5 Heil v. Strong, 44 Pa. 264. 
necessary openings to reach the coal. When anything is granted all the means to obtain it are granted. ${ }^{6}$

\section{Right of Support.}

414. Of natural right the surface land is entitled to support from the strata below. ${ }^{7}$

\section{Loss of Springs on Surface.}

415. The loss of springs to the owner of the surface by reason of the ordinary working of mines does not render the owner of minerals liable for damages. ${ }^{8}$

\section{Tenant Cannot Open Mines.}

416. It is waste for a tenant without authority to opera mines and take minerals. He can work open mines. ${ }^{9}$

Rent to be Paid, though no Ciay be Taken Out, Not Damages.

4I7. An agreement to pay for the privilege of taking clay, whether exercised or not, is not for liquidated damages, but for a privilege. ${ }^{10}$

\section{No Warranty of Coal.}

418. In a lease there is no implied warranty that the lease contains coal-veins. ${ }^{11}$

\section{Relief in Case of Mistake.}

4I9. A lease was made upon the supposition that an oilwell was upon the demised premises. The well was upon the premises of another person, and it was held that the tenant was to be relieved from the mistake. ${ }^{12}$

6 Trout $v$. McDonald, $83 \mathrm{~Pa}$. I44.

7 Chadwick $v$. Coleman, $80 \mathrm{~Pa}$. 8r.

8 Coleman $v$. Chadwick, $80 \mathrm{~Pa} .8 \mathrm{I}$.

9 Griffin $v$. Fellows, $8 \mathrm{I} / 2 \mathrm{~Pa}$. II4.

Io Johnson $v$. Cowan, $59 \mathrm{~Pa} .275$.

II Harlan v. Coal Co., $35 \mathrm{~Pa} .287$.

I2 Mays v. Dwight, $82 \mathrm{~Pa}$. 462. 


\section{Tenants Taking Partners.}

420. Where a lease is made of certain coal mines to two persons as tenants in common, and the lessees afterwards associate themselves as partners for the purpose of mining, shipping and selling coal from the demised premises for the whole period of the lease, the leasehold is thereby converted into partnership assets, and becomes the property of the firm. ${ }^{13}$

\section{Forfeiture for Not Developing Favored.}

42I. Forfeiture for non-development or delay is essential to private and public interests in relation to the use and alienation of property. In such cases as this equity follows the law. In general, equity abhors a forfeiture, but not where it works equity and protects a land-owner from the laches of a lessee whose lease is of no value till developed, except for a purpose foreign to the agreement. ${ }^{14}$

\section{Manner of Conveying in Case of Sales of Minerals.}

422. The technical words grant, bargain and sell, or the like, are not necessary to the creation of a separate estate in the coal, provided the intention to sell the coal is manifest. $^{15}$

The reports of the decision of cases in Pennsylvania abound with questions as to whether or not there is a sale of coal, and it will be best, if a sale is intended, to have the deed to conform as nearly as possible to a regular deed of conveyance of real estate.

\section{Questions as to Whether there is a Sale, a Iease or Right to Tako Coal Without a Sale.}

423. It is held to be settled that an instrument which is in terms a demise of all the coal in. under and upon a tract of

13 Patterson $v$. Silliman, $28 \mathrm{~Pa} .304$.

14 Mowne $v$. Armstrong, Leg. Int., July I4, 1882.

I5 Finnegan $v$. Stineman, $5 \mathrm{~Pa}$. Super. Ct. I24. 
land, with the unqualified right to mine and remove the same is a sale of the coal in place, and this, too, whether the purchase-money stipulated for is a lump sum or is a certain price for every ton mined, and is called rent or royalty. There is no distinction to be made between a perpetual lease and a term lease as to the application of the above law. There will be a sale, notwithstanding a term is created within which the coal is to be taken out. ${ }^{16}$

A deed of bargain and sale, with words of inheritance, granted the perpetual right to mine, dig, and carry away coal in certain veins. A royalty was reserved to the grantor on all coal mined. It was held that the omission of the word "all" before coal, and the reservation of the word "royalty," showed that it was not the intention of the parties to convey the coal absolutely, or to exclude the grantor from mining. No time was fixed for payment of the royalty, and there was no covenant requiring the grantees to mine. There was no consideration for the sale. There was a grant of the privilege of raising iron ore at twenty-five cents per ton, there was only a sale of the privilege. After referring to numerous cases, and considering them, the court said that it will be observed that in every case where it is held that an exclusive right was conveyed, a deed in expressed words granted all the mineral or provided payment for all. ${ }^{\mathbf{1 7}}$

(See further on this subject Practical Directions, Chapter . XXV.)

\section{Mining by Tenants in Common.}

424. A tenant in comimon may mine, but if he does so he will have to account to his co-tenants for their shares.

No presumption of partnership arises from the operation of an oil well by tenants in common. ${ }^{18}$ Tenants in common may become partners; but the law will not create the relation

16 Finnegan $\%$ Stineman, $5 \mathrm{~Pa}$. Super. Ct. I24.

I Jennings $v$. Beal, $158 \mathrm{~Pa} .283$.

I8 Neill $v$. Shamburg, $158 \mathrm{~Pa} .263$. 
for them as the consequence of a course of conduct naturally referrable to the relation existing between them. ${ }^{19}$

\section{Oil and Gas Leases.}

425. The grant of oil and gas privileges cannot be of oil and gas in place, as in case of coal, iron and other minerals.

On the lease of land for the sole purpose of drilling and operating for oil and gas, the lessee's right is in the nature of easement of entry and examination, with a right of possession arising where the particular place of operation is selected for egress, storage, transportation, etc., during the continuance of operations. The real subject of possession to which the lessee is entitled is in the oil and gas contained in or obtainable through land; these are minerals ferc naturc, and are part of the land and belong to the owner only so long as they are in it and under his control. The lessee, when he has drilled a gas well and controls the gas produced thereby, is in possession of all the gas in the land.

There was a lease of exclusive right and privilege of operating for oil for the term of fifteen years. It was for a definite term. It was only a grant of the exclusive right to operate for oil, not a sale of the oil. It must be treated as a lease for the production of oil and not as a sale of the oil or the land. ${ }^{20}$

Right to Mine for Oil or Gas is Necessarily Exclusive of the Right of the Landlord to Mine.

426. This principle arises from the necessity of the case. The joint operation of the landlord and tenant would possibly conflict, and the tenant may be deprived of all the benefits of the gas or oil on the premises.

\section{Liability to Pay Compensation in Case of Exhaustion of Mines.}

427. Where the lessor in a coal lease sells to the lessee all

19 Dunham v. Loverock, I58 Pa. 197.

20 Duffield $\%$. Rosenzweig, I44 Pa. 520. 
the coal in the land described in the lease at a certain minimum royalty per year for a term of years, whether there was any coal or not; and both parties know of the existence of workable and marketable coal in the land, although they do not know the quantity of coal, the fact that the coal is exhausted before the end of the lease will not relieve the lessees from the payment of the minimum royalty for the term of years because of such exhaustion of the coal. ${ }^{21}$

The parties contracted with reference to iron which was supposed to exist, and did exist on the lands demised. There was no agreement to pay a fixed, absolute sum for ore in place. The lessee was bound to use all proper efforts to find ore to mine, and to take it away. He was only bound to pay for the ore as mined or as it could be mined; and if the ore was exhausted before the termination of the lease, the obligation to pay royalty ceased. In this case Fulmer simply agreed to mine a thousand tons of ore each year, and to pay seventeen and one-half cents per ton, whether he mined or not. That is, if he failed to mine the quantity of ore he agreed to take out, he paid for it just as if he had mined it. But it is only for ore which he might have taken out if he would. If the ore was not there, he was under no duty to pay, because he never could get it. The foundation of his liability to pay was the supposition that the ore was there. If the ore was not there the fundamental condition of all liability is gone. ${ }^{22}$

Obligation to Drill Though Land Worthless for Oil or Gas.

428. After a lease was executed it was claimed that the demised premises were worthless for either oil or gas; that the land did not contain either oil or gas in paying quantities. It was held that such claim would not be a defence in a suit for sums to be paid for not drilling, etc.; that the damages for delaying to drill were fixed and liquidated by the parties, and that only in this way or by reserving rent could the land- 
owner make himself sure of any compensation for allowing an oil or gas lease to become and remain an encumbrance of his property. ${ }^{23}$

\section{Kortgages of Mineral Leaseholds.}

429. In case of a mining lease it can be mortgaged like a chattel; and a mortgage in such case will not be subject to the act of June 8, I88I, providing against absolute conveyances with parol and unrecorded defeasances. That act is applicable to deeds for real estate only. Mining leases may be mortgaged and recorded, etc., under the act of April 27, $1853 \cdot{ }^{23 *}$

\section{Perpetual Lease of Ore Lands.}

430. A lease of coal lands for a certain period "and for such other and longer time as the lessee shall continue to pay rent is not invalid by reason of the uncertainty of the term." The case of Lewis $v$. Effinger, $30 \mathrm{~Pa} .28 \mathrm{I}$, and Effinger $v$. Lewis, $32 \mathrm{~Pa} .367$, settle the validity of a lease for a term certain, and thereafter to continue at the will of the lessee. ${ }^{24}$ A perpetual lease at the will of the lessee may be created under the common law of Pennsylvania, inasmuch as livery of seisin is not necessary to pass an estate which may be equivalent to a fee simple. ${ }^{25}$

\section{Options to Drill or to Pay Rent.}

43I. An oil lease provided that the lessee should complete a well on the leased premises within six months "or in default thereof, pay to the party of the first part for further delay an annual rental of $\$ 500$, payable quarterly in advance." Held, that upon failure to drill the well within six months, the lessor was entitled to the stipulated rental. ${ }^{26}$

23 Springer $v$. Gas Co., I45 $\mathrm{Pa} .430$.

23* I P. \& L. Dig. 1607; P. L. 368, § 8.

24 Myers $v$. Coal Co., I26 Pa. 582. 25 Effinger v. Lewis, $32 \mathrm{~Pa} .367$. 26 Leatherman $v$. Oliver, .15 I Pa. 646; Galey $v$. Kellerman, 123 Pa. 491. 
Provisions for the Forfeiture of an Oil or Gas Lease for the Benefit of the Lessor Only.

432. It was provided that "a failure to complete said well, or pay said rental for ten days after the time above specified for so doing, shall render this agreement null and void, and it can only be renewed by mutual consent; and no right of action shall after failure accrue to either party on account of the breach of any promise or agreement herein contained." Held, that the lessor could enter upon giving ten days' notice, but that the lessee could not compel the lessor to terminate the lease. ${ }^{27}$

Right of Mining Tenants to Pollute Streams.

433. Damages resulting to another from the natural and lawful use of his land by the owner thereof are, in the absence of malice or negligence, damnum absque injuria. One opening a coal mine in the ordinary and usual manner, may, upon his own lands, drain or pump the water which percolates into his mine into a stream which forms the natural drainage of the basin in which the mine is situate, although the quantity of the water may thereby be increased and its quality so affected as to render it totally unfit for domestic purposes by the lower riparian owners. ${ }^{28}$

Liability for Manufacturing Coke and Injuring Crops, etc., of Adjoining Premises.

434. One who is engaged in manufacturing coke from coal not mined by himself, but purchased at mines of other persons, will be liable in damages for a substantial injury to the crops and soil of an adjoining farm, caused by the smoke and vapors emitted from his ovens. ${ }^{29}$

27 Springer $v$. Gas Co., I45 Pa. 430; Leatherman v. Oliver, 151 Pa. 646; Ray v. Gas Co., $138 \mathrm{~Pa} .576$.

28 Coal Co. v. Sanderson, $113 \mathrm{~Pa}$. 126.

29 Robb v. Carnegie, $145 \mathrm{~Pa} .324$. 
As to Whether or Not a Mining Lease has been Forfeited for Not Operating.

435. The acts and declarations of the tenant may evince an intention to abandon permanently the premises and operation. $^{30}$

Rights to Make Openings to Reach Coal.

436. A lease which gives the right to mine, to take out all the coal beneath a certain surface confers also the right to make all necessary openings to reach the coal. Tenant opened a new shaft near a barn, whereby a spring was destroyed. Held, that the tenant could do so; that if the destruction of the spring was a necessary incident of mining under the lease, it would be damnum absque injuria. ${ }^{31}$

Agreements for Diligence in Drilling and Working for Oil, etc.

437. It was held that ceasing operations for three months, and making no effort during that period to produce oil, was a ground for forfeiture. ${ }^{32}$

In Agreements for Coal Ieases Time is of the Essence of the Contract.

438. Held that as an interest was an oil and gas leasehold, liable to sudden changes in value, time was of the highest importance in dealing with it, and presumably the essence of all contracts in relation to its sale. ${ }^{33}$

Relief Against Forfeiture of an Oil and Gas Lease for Non-Payment of Rent.

439. The lessor in an oil and gas lease will not be permitted to enforce a forfeiture of the lease for a delay of one day in the payment of rentals where by his acts and declarations he has lured the lessee into the belief that a forfeiture will not be enforced for so short a delay. ${ }^{\mathbf{3 4}}$

30 Karns $v$. Tanner, $66 \mathrm{~Pa} .297$. 3r Trout $v$. McDonald, $83 \mathrm{~Pa}$. 144.

32 Kennedy $v$. Crawford, $138 \mathrm{~Pa}, 56 \mathrm{r}$.

33 Kelly v. Marshall, I72 Pa. 396. 34 Steiner v. Marks, I72 Pa. 400. 13 
Partnership in Mineral Leaseholds.

440. A demise of land for a term of years, "with the sole and exclusive privilege, during said period, of digging and boring for oil and minerals, and of gathering and collecting the same therefrom," conveys an interest in the land, a chattel real, but none the less a chattel. Though such a leasehold be held by owners in undivided shares, under instruments made to them in their individual names, yet the property being a mere chattel, the owners by associating as partners in its operation and development, may convert it into partnership assets; and such association may be established by evidence of the several admissions of the alleged partners, or the admission of one and the acts and declarations of others. If one partner assigns his interest in the leasehold without the knowledge and assent of the others, such assignment is subject to the equity of the other partners to have the partnership debts then existing first paid out of the partnership assets. ${ }^{35}$

\section{Relief Against Forfeiture of Mining Leases.}

44I. Where time is not stipulated as essential and a forfeiture for non-payment of money, or other matter that admits of accurate and full compensation, is provided as a mere penalty whose object is to enforce performance of another and principal obligation, equity will relieve against it and will not permit it to be used for a different and inequitable purpose. ${ }^{36}$

A Lease for Exploration for Oil Ceases when Exploration Finished.

442. An oil lease contained a grant of a right to mine and remove oil for a fixed period of twenty years at a royalty of one-eighth of the oil so mined and removed. Held, that the right of the lessee was to explore for and determine the existence of oil under the land and if none were found, his right 
ceased when the explorations were finished and the lot abandoned. ${ }^{3 \tau}$

\section{Interest on Royalties.}

443. Where a coal lease provides for an annual rental, payable quarterly, and a royalty for coal mined in excess of a specified quantity, and in the course of dealing between the parties the lessor frequently accepted royalties long after they were due, without demanding interest on the same and finally gave a receipt "in full payment for coal rent in excess of minimum," and it appears that the receipt was not given under a mistake as to any matter of fact, the representatives of the lessor cannot, after his death, recover interest on the royalties which had accrued and were paid prior to the giving of the receipt. Interest is a legal and uniform rate of damages allowed in the absence of any express contract when payment is withheld after it has become the duty of the debtor to discharge his debt. When a balance of an account was paid without any charge for interest it cannot be claimed. When there is a stipulation for interest it may be recovered even after the principal debt has been paid; but it is otherwise when the interest is recoverable merely as damages or as an incident to the debt. A receipt in full is in effect a stated account and if interest is not claimed it is waived by the receipt. $^{38}$

Tenant Will Not be Compelled in Equity to Test Land for Oil or Gas if there is no Fraud.

444. A bill in equity will not lie by the lessor of an oil and gas lease against the lessee or his assigns to compel the latter to test part of the leased land not yet drilled, or upon his failure to do so, to surrender the land to the lessor, unless it is shown that the failure of the lessee to drill amounts to a fraud upon the rights of the lessor. ${ }^{39}$

37 Oil Co. v. Fretts, I52 Pa. 45I. 38 Waller v. Coal Co., 191 Pa. 193.

.39 Young $v$. Oil Co., $194 \mathrm{~Pa} .243$; Calgan v. Oil Co., I94 Pa. 234. 
Covenants to Pay Royalties Run with the Land.

445. Covenants to pay royalty in an oil lease run with the land and are binding upon the assignee who has received the production from the wells. ${ }^{40}$ An assignment of an oil and gas lease in consideration of a certain sum paid at the time of the assignment and the further consideration of the sum of $\$ \mathrm{I}, 000$ if oil is found, etc., creates no covenant running with the land and the assignor is not entitled to recover from an assignee of the assignee the $\$ 1,000 .{ }^{41}$

When Lessee to Follow his own Judgment in Sinking Additional Wells.

446. Where a lessee under an oil and gas lease has entered upon land and sunk wells he is entitled, in determining whether he shall sink additional wells, to follow his own judgment. If that is exercised in good faith, a different opinion by the lessor, or the experts, or the court, or all combined is of no consequence, and will not authorize a decree interfering with him. ${ }^{42}$

The Meaning of the Phrase, "To Continue so Long as Oil or Gas are Produced in Paying Quantities."

447. Where a lease is to continue as long as oil or gas is found or produced in paying quantities, the phrase "found or produced in paying quantities" means paying quantities to the lessee or operator. If a well, being down, pays a profit, even a small one, over the operating expenses, it is producing in "paying quantities," though it may never repay its cost, and the operation as a whole may result in a loss. ${ }^{43}$

Where an oil or gas lease provides that the lessee shall market gas if "found in sufficient paying quantities to justify marketing the same," the lessee must do so but he will not be required to do so at a loss, but only at a reasonable profit; and in determining whether it could be so marketed, the distance to market, the expense of marketing and every cir-

40 Williams $v$. Short, $155 \mathrm{~Pa} .480$. 42 Young $v$. Oil Co., I94 Pa. 243.
4I Fisher $v$. Guffey, $193 \mathrm{~Pa} .393$. 43 Young $v$. Oil Co.. $194 \mathrm{~Pa} .243$. 
cumstance of a similar kind should be taken into consideration. ${ }^{44}$

Necessity of Having Oil Leases Recorded.

448. Where the lessees in an oil lease fail to put their lease on record and never go into actual possession or occupation of the land, their title may be cut out by that of a subsequent purchaser for value without notice. ${ }^{45}$

Jurisdiction in Equity for Account of Gas, etc.

449. The lessor can have discovery and account in equity relating to his share of the profits of gas, etc. ${ }^{46}$

Rent may be Payable in Oil or Gas.

450. Rent need not be money, it may be a share in the product, as the share in an oil lease or the share of the proceeds of the sale of gas in a gas lease. ${ }^{47}$

Liability of Assignee of an Oil or Gas Lease for the Payment of Royalties.

45I. The assignee of an oil or gas lease will be liable for the payment of royalties which accrue whilst holding the assignment of the lease, the covenant to pay royalty runs with the land. 48

Owing to his privity of contract with the lessor, a lessee's liability upon his covenants in an oil and gas lease continues after his assignment of the lease; but an assignee of the lease being in privity of estate only with the lessor, is liable only upon covenants which are broken while his privity of estate exists. An assignee would not be liable to drill a well when the time for performance had elapsed before the assignment. but the obligation of a covenant to prosecute the business of developing the land is a continuing one. ${ }^{49}$

44 Iams $v$. Gas Co., I94 Pa. 72.

45 Aye v. Phila. Co., 19.3 Pa. 457.

46 Stone v. Oil Co., $188 \mathrm{~Pa} .602$.

47 Stone $v$. Oil Co., $188 \mathrm{~Pa} .602$.

48 Fennell $v$. Guffey, I55 Pa. 38; Stone v. Oil Co., I88 Pa. 602; Fennell v. Guffey, I39 $\mathrm{Pa}$. 34 $\mathrm{I}$.

49 Gas Co. $v$. Johnson, т23 Pa. 576. 


\section{CHAPTER XXV.}

PRACTICAL DIRECTIONS IN MATTERS RELATING TO THE RENTING OF PROPERTY.

PAGE 199.

SECTION

452. Examination of the property.

453. See what neighbors can do in diminishing the value of demised premises.

454. Inquiries of landlord before renting.

455. False representations by lessee.

456. See if demised premises in the city of Philadelphia are liable to be taken for public use.

457. Examination of the title of the landlord.

458. Examination as to encumbrances.

459. See if lease can be destroyed by an orphans' court sale.

460. See if there is a liability for a distraint for taxes.

46r. Obtaining rights for a show case.

462. Obtaining sign rights by tenant.

463. Provisions in case of fire or other casualty.

464. Directions for making rents certain for distraint and possession.

465. Directions in case of an underletting.
SECTION

466. Giving riglits to tenants to purchase.

467. Fixtures of tenant to be protected in cases of renewed leases.

468. Making a penalty to be paid as rent.

469. Directions in taking assignments of leases.

470. Provisions prohibiting parol testimony to affect written leases.

471. Restrictions as to the use of demised premises.

472. Making rent due in advance by occurrences after the lease.

473. Providing against the liability of the owner for nuisances.

474. Prevention of defences being waived by paying rent or other action.

475. Prevention of the termination of farm leases by death of tenant.

476. Provisions for amicable ejectments.

477. Providing for distraint after removal of tenant.

478. Giving sub-tenants the benefit of the exemption law. 
SECIION

479. Providing for surety in eases oi extensions of lease.

480. Getting the consent of the surety to alter lease.

481. Extension of right to terminate lease to assignees, etc.

482. Danger of landlord losing his right to rent by the nonperformance of an entire contract.

483. Cautions in preparing agreements for the extension of term and for options.

484. Necessity of a consideration for an agreement to change the terms of a lease.

485. Protecting landlord in farm leases.

486. Making the payment of taxes, charges, etc., as rent.

487. Necessity of reading leases.

488. Protecting fire insurance from conduct of tenant.

489. Distinguishing between a lease and sale in granting mining rights.

490. Necessity of a particular description of the extent of a right to mine.

49I. Ascertaining if any old mining leases are outstanding.

492. Protection to landlord who reserves the surface in a lease to mine.

493. Binding remainderman in case of a lease by tenant for life.

494. Necessity of recording oil lease when tenant does not take possession.

Examination of the Property.

452. The property proposed to be rented should, if possible, be examined thoroughly. As to the parts thereof which cannot be well examined, inquiry should be made.
SECTION

495. Necessity for having time fixed for delivery of landlord's share of crops.

496. Protection of parties in agreements to pay for taxes, charges, assessments, etc.

497. Dangers in using clause that landlord may change terms of lease.

498. In case of doubtful construction, the tenant favored.

499. Fixing a time for the tenant to perform an agreement to make improvements.

500. Protecting landlord's right to tenant's fixtures at the end of the lease from levy, etc.

50r. If an assignee assigns his lease and retains an interest he will remain liable.

502. Necessity of having a clause for forfeiture for a breach of a covenant not to assign.

503. Guarding against the breach of trifling covenants giving the right to recover possession.

504. In case a tenant agrees to use or not to use demised premises for a certain business or purpose.

505. Danger of there being a breach of a covenant not to assign lease by taking a partner.

506. Necessity for a description to locate prenises in leases or amicable ejectments.

506*. Giving right to distrain off the demised premises. 
The premises may be out of repair and in bad condition, but these circumstances would be no ground for a legal complaint by a tenant.

A tenant discovered that demised premises were wholly in an unfit and uninhabitable condition, owing to the defective construction of the drains. Having been informed by his physician that it would be dangerous to remain on the premises, he removed therefrom, and it was held, that the defects were no defence to a claim for rent. ${ }^{1}$

A tenant leased premises to be used as a saloon. After he took possession he discovered that they had a bad reputation. In consequence of such reputation the business people of the neighborhood did not care to enter them. It was held that the tenant was bound to pay the rent; that there was no relation of confidence between landlord and tenant; that they deal as strangers; that the tenant should have inquired into the reputation of the premises; that mere silence in regard to a material fact, where there is no legal obligation to disclose, will not avoid a contract, although it operates as an injury to the party from whom the fact is concealed. ${ }^{2}$

There is no implied covenant that the landlord warrants the leased premises to be tenantable, or that he undertakes to keep them so, in the absence of a provision in the lease that the landlord shall repair. A tenant having abandoned the premises, alleging that they were not habitable, it was held that he was liable for the rent for the remainder of the year. ${ }^{3}$

These cases, selected from a large number, are sufficient to show the necessity of the examination and inquiry recommended. If landlord is to repair, the lease should so provide.

It is a general practice for landlords to repair and keep rented premises in good condition; and this practice has led to a general erroneous belief that the landlord is bound to

I Hollis $v$. Brown, I59 $\mathrm{Pa} .539$.

2 Twibill $v$. Brown, 17 W. N. C. 22 I.

3 Reeves $v$. McCormick, I68 Pa. 57 I. 
conform to this practice. ${ }^{4}$ The consequence has been that a large amount of litigation has arisen for want of a knowledge of the laws on this subject. The landlord can agree in the lease to repair and keep in good condition, but should make an exception in case of fire and other casualties, if he should need such protection.

See what Neighbors Can Do in Diminishing the Value of Demised Premises.

453. A bill-posting company rented the roof and wall of premises for the display of advertisements on the wall by means of a stereopticon; and a neighbor placed a structure so that it prevented advertisements being seen from the streets. The lease was rendered practically valueless, and the tenant refused to pay the rent. It was held that the landlord was not responsible; that the covenant for quiet possession relates only to the acts of the lessor and those claiming under him, or the holder of a better title. This case shows the necessity there is for tenants to consider, before renting property, what may be done by the owners of adjoining or neighboring properties to their prejudice. ${ }^{5}$

\section{Inquiries of Landlord before Renting.}

454. The proposed tenant can question the landlord as to everything he desires to know about the premises; and if the landlord should give any false or fraudulent answers to such questions, they will be a ground for defence. A lessor falsely represented that he had an offer of $\$ 20,000$ for a lease. The real offer was one of but $\$ 10,000$; and the lessee obtained a judgment against the lessor for $\$ 10,000$ - the difference, in an action for deceit. ${ }^{6}$ A tenant contemplating a lease of premises for the purpose of using them as a millinery store, inquired of the landlord as to the condition of the bulk show-

4 Huber $v$. Baum, I52 Pa. 626.

5 Oakford $v$. Nixon, 39 W. N. C. 49.

6 Guffey $v$. Clever, I46 Pa. 548. 
windows, and was told by him that they had new roofs and were in perfect condition. The roofs of these windows were not new, and were in bad condition. It was held that the landlord was liable for the deceit. ${ }^{7}$

In case the proposed landlord is questioned as to the condition of the premises or other matters relating thereto, and is mistaken in his answer, without any intention to deceive or defraud the tenant, that tenant will have no remedy for such erroneous answer. In case the representations of a landlord are relied upon it will be best to have them in the shape of an agreement in a lease, or in a paper executed therewith.

\section{False Representations by Lessee.}

455. The landlord can question the tenant concerning his ability to pay the rent, and other existing matters relating to the tenancy. A lease may be avoided by the lessor at his option where he was induced to make the lease by false representations of the lessee. ${ }^{8}$

See if Demised Premises in the City of Philadelphia are Liable to be Taken for Public Use.

456. For the city of Philadelphia there are plans to show streets opened and unopened. Where a lease is of property in Philadelphia in an unimproved neighborhood, which lease is to exist for a considerable term, and improvements will be erected by the lessee, it may be well to see whether or not any unopened streets on the city plan are made to run through the demised premises, and what effect the opening of such streets will have upon such improvements. In case any improvements are built on such unopened streets, it may be that the tenant can recover no damages from the city.

\section{Examination of the Title of the Landlord.}

457. See that the proposed landlord has a good title. This

7 Sacks $v$. Schimmel, 39 W. N. C. 452.

8 Harvey $v$. Gunzberg, I48 Pa. 294. 
should be done especially in cases where the lessee intends to expend a considerable sum of money for improvements. The tenant can question the landlord as to his ownership; but if he wishes to be thoroughly satisfied and protected, he should have the title examined or insured. The law implies a covenant of the landlord that the tenant shall have undisturbed possession of the demised premises during the term, but it seems that such a covenant will be an insufficient protection.

It was held that where a tenant was evicted during his term by the holder of a paramount title, without fraud on the part of the lessor, his measure of damages was the consideration paid by him. If he had paid only the rent during the term of his possession, he was entitled to only nominal damages. In such case the lessee was not entitled to recover the value of the improvements for the prosecution of his business-some of the improvements having been erected in pursuance of a covenant made by him in the lease, and which improvments, by the terms of the lease, the lessee had the right to take down and remove at the end of the term. ${ }^{9}$

\section{Examination as to Encumbrances.}

458. See that there are no charges or encumbrances which may result in a sheriff's sale of the premises and the destruction of the lease. As to any judgments, municipal claims, or mortgages, the lessee can procure certified searches, as in the case of purchase of a property. In case of a sheriff's sale upon a prior encumbrance, the purchaser can give notice for possession, and break the lease. There may be proceedings on mortgages, or for arrears of ground rent; and such proceedings may result in leases being broken by sheriff's sale. It was held that a tenant can tender payment of the amount due on a prior mortgage, and have the owner of the same restrained from selling. ${ }^{10}$

9 Lanigan $v$. Kille, 97 Pa. I20.

Io Hartman v. Quay, I Chester Co. R. 487. 
In proceedings by sheriff's sale under mortgages, ground rents, and even under judgments, the effect may be to destroy what are known as easements-such as rights of way, and the like-created after the recording of the mortgage, the creation of the ground rent, or the entry of the judgment.

See if Lease can be Destroyed by an Orphans' Court Sale.

459. Purchasers at orphans' court sales will have the same right to break leases that purchasers at sheriff's sale have. In case an owner of the property proposed to be rented should be lately deceased, it ought to be ascertained whether or not there is any probability of the property being sold by order of court to pay the debts of the decedent. The lien of debts will expire at the end of two years from death of lessor if no statement is filed as by law provided.

\section{See if there is a Liability for a Distraint for Taxes.}

460. In case property in the city of Philadelphia is leased. ascertain whether or not there are delinquent taxes; for if there are, there will be a liability of the goods on the demised. premises to be seized upon for the payment of the taxes. Any taxes, however, paid by the tenant to the tax collector, will be considered as payments on account of rent.

\section{Obtaining Rights for a Show Case.}

46r. In renting a business place it may be desirable to have the privilege of exhibiting a show-case at the street entrance. In such case the lease should provide for the privilege. As to the entry, the tenant will only have a right of way. It may be desirable to have a show-case at the front door. on the outside. There may be public authority for the placing: of such show-cases. In that case authority can be obtained from the owner for such outside show-case and the like. The first floor was rented to a merchant tailor. The second floor was rented to a photographer. The tailor complained that the photographer had placed a show-case upon the pave- 
ment by the side of his door. It was held that all that any of the tenants had was an uninterrupted passageway in common with the public. If the tailor, when he rented the premises, had wanted to have the door and passageway clear, he could have attained that end by a provision in the lease; provided the lease to the photographer was not in the way. ${ }^{11}$

Obtaining Sign Rights by Tenant.

462. If a tenant desires to have any rights to have signs on the walls he should contract for them. Where a tenant rents a floor, he rents the inside, and not the outside, and he has no right to put out a sign in front, unless with the consent of the landlord. ${ }^{12}$

\section{Provisions in Case of Fire or other Casualty.}

463. When a tenant rents an upper floor merely, and such floor shall be wholly destroyed by fire or other casualty, without his fault, in case there is no covenant to rebuild, the lease ends and the rent ceases; ${ }^{13}$ but this is not so in case a tenant rents a whole property or from the ground. $\mathrm{He}$ is without any protection in the lease; he is liable to pay rent, although the premises are destroyed by fire or other casualty, and of late it has become customary to have the tenant protected in his lease against such results.

There is a variety of ways of having such agreements made in leases. In case of the total destruction of the premises by fire, without the fault or neglect of the tenant or of his agents or servants, there may be a provision that the lease shall become void; provided, however, that all back rent, and the current rent apportioned up to the date of the fire, may be recovered under and according to the terms of the lease.

In case of a destruction in part, by fire, so that the premises may be repaired by the landlord, there can be a provision

II Cunningham $v$. Eentrekin, I5 Pa. C. C. R. I83.

I2 Hall $v$. Stewart, 19 W. N. C. I29.

I3 Camp v. Casey, $7 \mathrm{~Pa}$. C. C. R. I6o. 
that the landlord shall repair, and that the tenant shall not be required to pay any rent during such time as he may be required to vacate the premises while repairs are being made. In case, however, he remain in possession of the premises, and be deprived of the use of but a part thereof, he could be allowed a just proportion of the rent for the parts not occupied during the repairs.

The most difficult transaction to provide for is the renting of a place of business. If a loss in part shall be so great as to hinder or prevent the tenant from continuing his business, it may be best to agree that the lease shall terminate; but if the loss will not materially prevent such continuation, the landlord can agree to repair, and the tenant can be allowed a just deduction from his rent for the loss of the use of the parts destroyed during repairs.

To protect the landlord, the rental value of the parts destroyed should be the only measure of the allowance. As to the loss to business, the tenant may not be able to protect himself by insurance further than the loss of goods. There may be a loss in part, leaving to the tenant room and conveniences sufficient to continue the business; but he may not be able or willing to do so, by reason of a great or entire loss of stock, fixtures, machinery, etc.; and such conditions may be made grounds for terminating the lease.

There may be a lease of land with several buildings thereon used as a plant for carrying on manufacturing business, and one of the buildings in which a particular branch of the business shall be carried on may be destroyed and the tenants cannot wait for the repair or rebuilding, and it may be to the interest of the tenant for the lease to terminate, and in another case one or several of a number of buildings may be destroyed but a business can still be carried on in the others until the lost or damaged building or buildings are rebuilt or repaired.

In some cases an arbitration clause will be useful to decide in case of a dispute as to the right to remove and to fix the 
amount of the deduction for rent following a partial loss and continued occupancy.

Directions for Making Rents Certain for Distraint and Possession.

464. The acts of assembly for the recovery of the possession of property at the end of the term require that the rent shall be certain. The act for the recovery of the possession of rented properties for the non-payment of rent indicates that it applies only to cases where the rent is certain; and rent made certain is one of the essentials for making a distress for rent. These requirements make it important that the rent shall be made certain. The requirement of certainty, however, does not mean that the rent must be payable in money. It may be paid in any commodity whose value may be accurately estimated in money. Rent may be payable in the proportion of the toll of a mill, or of a proportion of iron or wheat. ${ }^{14}$ There may be cases where nearly the whole rent is made payable in money, yet there may be a provision concerning some small matter whereby the whole rent may be rendered uncertain. If rent is to be paid in produce, or from products from mining, it may be necessary to have an accounting and settlement; and in important leases there can be provisions for such accounting and settlement at certain periods; and in case of the tenant's default there can be a provision for the landlord's annulling the lease and recovering possession by amicable ejectment, or in case of disputes as to accounts there can be a provision for arbitration.

\section{Directions in Case of an Underletting.}

465. In case of an underletting the under-tenant will take, of course, subject to the terms of the lease of the head landlord, and subject to all rent due, and which shall fall due, to him. There may be a provision in the lease whereby the first tenant cannot underlet without the written consent of

I4 Jones $v$. Gundrim, 3 W. \& S. 53I. 
the landlord. If there be any such requirement in the lease it should be complied with. It may happen that the undertenant will promptly pay his rent to the first tenant (his landlord), but that such landlord will not pay his rent to the head landlord; and the consequence may be that the under-tenant's goods will be distrained upon for rent, although he has paid his rent to his own landlord.

In case a lessee for years transfers his interest to a third person, with a reservation of rent, he cannot distrain for his rent unless the sub-lease contains an express power of distress. $^{15}$

Giving Rights to Tenants to Purchase.

466. It sometimes happens that the tenant is given an option (or the privilege of purchasing) the demised premises during the term of the lease. In such case it will be well to have the terms of sale fully expressed in the lease, so that, in case of a resort to a court of equity, a decree for specific performance can be granted. To protect the right of the tenant to purchase it may be important that notice should be given by having the lease acknowledged and recorded.

If the tenant is in possession, possibly that would oblige any one purchasing from the landlord to inquire of the tenant as to whether or not there is an agreement to purchase the premises.

In case there is an option in the lease for the tenant to purchase, there may be danger to the landlord, upon the tenant's exercising his option, of such tenant's being in possession of the premises as purchaser before the execution of a deed and settlement. To avoid this result it can be provided in the lease that the tenant shall remain as such until the execution and delivery of the deed and the settlement for the purchase. ${ }^{16}$

Knowledge of the existence of a lease will not relieve one

I5 Manuel $v$. Reath, 5 Phila. II.

I6 Newell's Est., 100 Pa. 513; Knerr v. Bradley, 105 Pa. I90. 
dealing with the lessor from the duty of inquiring of the person in possession whether he claims otherwise than under the lease, the possession, apart from the lease, being notice of the possessor's claim of title, whatever that may be. ${ }^{17}$

\section{Fixtures of Tenant to be Protected in Cases of Renewed Leases.}

467. If a tenant, at the expiration of his lease, does not remove his fixtures, they become the property of the landlord. If a tenant, at the close of his term, renews his lease and acquires a fresh interest in the premises, he should take care to reserve the right to remove such fixtures at the end of the extended term. Where his continuance in possession is under a new lease, his right to remove fixtures is determined, and he is in the same situation as if his landlord, being seized of land, together with the fixtures, had demised both to him $;^{18}$ and as this doctrine may be upheld by our courts, it will be well to have the reservations recommended.

\section{Making a Penalty to be Paid as Rent.}

468. A tenant agreed to pay a penalty, in the nature of rent, as punishment for the breach of a covenant not to carry on business on the demised premises; and this penalty was to be paid in addition to the amount of rent, in equal monthly payments, at the time of the payment of the rent. It was held that the penalty, in fact, was not rent, and that it could not have the incident of distress because that incident pertains only to that which, in strict legal contemplation, is rent. There was not a stipulation for a right to distrain. The distinction between that which was rent and that which was penalty was preserved throughout the agreement. The court seemed to intimate that if the penalty had been definitely named as additional rent, and if a power of distress had been given, there might have been a right of distress. ${ }^{19}$

17 Anderson $v$. Brinser, 129 $\mathrm{Pa} .376$.

18 Taylor on Landlord and Tenant (4th Ed.), 405.

I9 Latimer $v$. Groetzinger, 27 W. N. C. 223. 


\section{Directions in Taking Assignments of Leases.}

469. In case of the taking of an assignment of a lease it should be ascertained whether or not there exists any prohibition against the tenant's assigning his lease. Leases generally require the written consent of the landlord for the tenant to assign or underlet, and if so, such assent should be obtained.

Of course, in case of the assignment of a lease, the lease should be examined by the proposed assignee, and the assignor or his landlord can be questioned as to whether or not there have been any changes in the terms of the lease. Records can be examined, or the tenant questioned, to ascertain if he has mortgaged his lease under acts of assembly or otherwise.

An assignee will only be liable for the payment of rent, or for the performance of agreements during the time he holds the demised premises as such assignee.

To protect the landlord against assignments without his assent, the prohibitory clause should be made to extend and apply to all assignments after the first with consent, and to all assignments by operation of law, or in any way whatever.

\section{Provisions Prohibiting Parol Testimony to Affect Written Leases.}

470. In negotiations for a lease it often happens that conversations take place about the terms thereof; and, to prevent the admission of such testimony there can be a clause in the lease providing that parol testimony will not be admissible to show any agreement, term or provision not in the lease.

\section{Restrictions as to the Use of Demised Premises.}

47I. The lease may provide that the premises may be used solely for a certain purpose, or that the premises shall not be used for certain purposes. The tenant will have a wide latitude to carry on business if there is no restriction; and it may be a business prohibited in fire insurance policies. 
Making Rent Due in Advance by Occurrences after the Lease.

472. There can be a stipulation in the lease that if the lessee should become embarrassed, make an assignment for the benefit of his creditors, or be sold out at sheriff's sale, the whole rent for the balance of the term shall become due and payable in advance; and the landlord can be preferred in the distribution of the proceeds of the sheriff's sale of the tenant's goods to the extent of one year's rent, although the rent be payable in advance, as aforesaid. ${ }^{20}$

\section{Providing Against the Liability of the Owner for Nuisances.}

473. An owner of real estate cannot, by leasing the same to a tenant, avoid liability to a third party for the continuance of a nuisance on the premises, which, before such leasing, it was his duty to abate. A lessor out of possession is liable in damages to a third party for continuance by his tenant of a nuisance arising from a well and private sewer that were either defectively constructed or out of repair at the beginning of the lease. If the tenant contribute to the nuisance by use of the well and sewer, he will be liable; but such liability would not relieve the landlord of his duty to see that his property, before it passed out of his possession, was in such condition that its use would be uninjurious to his neighbors. The landlord should be careful that there are no nuisances on the property at the time he rents-and in some cases it would be well to have witnesses who have inspected the premises and who will testify as to the condition of the property at the time of the lease.

\section{Prevention of Defences being Waived by Paying Rent or other Action.}

474. Where a lease provided that a building should be completed by a certain date, and the lessor failed to keep that part of his contract, and the lessee made a large number of payments of rent after entering, without making any claim

20 Platt $v$. Johnson, т68 $\mathrm{Pa} .47$. 
for deduction on account of the delay in obtaining possession, he was held to have waived any right that he had to make such a claim. ${ }^{21}$ Sometimes tenants may think it best to be protected against such waivers by their actions, and in paying rent, payments may be made under protest.

Prevention of the Termination of Farm Ieases by Death of Tenant.

475. There is a conflict of authority as to whether or not a farm lease will terminate with the death of the tenant; and if that is not the intention there can be a provision in the lease to the contrary.

\section{Provisions for Amicable Ejectments.}

476. For the protection of the landlord it has become common to have an agreement in the lease for the entry of a judgment in ejectment for the recovery of the demised premises by the landlord, in case the tenant makes default in the payment of rent or breaks any of his agreements. Such an agreement will be of great benefit to the landlord, as otherwise legal proceedings may be necessary to recover possession, whereby there may be great delay and troublesome litigation.

According to the decisions, the landlord may lose his right to such a provision for amicable ejectment for non-payment of rent if he has been in the habit of giving time to the tenant to pay the rent after it is due, and thereby leading the tenant to believe that a forfeiture will not be insisted upon. To avoid such a result, the lease can provide that in case the landlord shall not demand or collect his rent when due, or in case, by words or actions, he shall have given additional time to the tenant to pay his rent, any such circumstances or actions shall not be set up as a defence against the amicable suit and judgment in ejectment, and that the landlord may institute such suit and obtain such judgment without notice to the tenant.

21 Murphy $z$ : Marshall, 39 W. N. C. 446. 
In entering the suit and judgment, that tenant alone who has signed the lease, or his assignee, if right is given to the assignee, should be made a party defendant. If he alone is made a party, the sheriff under his execution can put an under-tenant, and all persons claiming any right to possession under the tenant, out of possession. There should be a provision that the clause in question shall apply to the heirs, executors, administrators and assigns of the parties.

There was an amicable action in ejectment and confession of judgment. The record showed as a ground for the forfeiture of the lease that the tenant did not pay the rent. The judgment was stricken off, one of the reasons being "that there being no place named in the lease for the payment of the rent, the landlord was bound to be on the premises by himself, or his agent, on the day or days when the rent fell due, ready to receive the same, and if he allowed these days to pass, then, before he could declare a forfeiture, he must demand the rent of the defendant in person." 22

To avoid any questions like this the lease can provide that the rent shall be paid to the lessor at his residence. place of business, or at any place the lessor may designate.

Where a lessee for years holds over after the expiration of his term, he is tenant from year to year, subject to all the covenants and stipulations in the original lease, so far as they are compatible with a yearly holding; but a warrant of attorney for a confession of judgment in ejectment for nonpayment of rent, etc., contained in the lease limited to the former year is not applicable to the new situation unless made so by express agreement. ${ }^{23}$ This case is not like McBrier \%. Marshall, I26 $\mathrm{Pa}$. 390, in which there was an option to hold for an additional term.

Leases generally provided for a continuation of the term in case of a holding over, but in case of renting for only a 
certain term it will be well to agree that the rights and remedies to the ejectment shall extend to any renting whatever, by implication or otherwise, after the expiration of the term.

It will be well for the lease to provide for the filing of a copy of the lease in court in lieu of filing the original lease.

\section{Providing for Distraint after Removal of Tenant.}

477. In case the tenant removes his goods from the demised premises clandestinely, they can be followed and distrained upon for thirty days, as provided by an act of assembly; but in case there is no clandestine removal of the goods, they cannot be followed and distrained upon. Hence it is important to have a clause inserted in the lease that in case the tenant shall remove any of his goods from the premises, whether clandestinely or not, they may be distrained upon wherever found, say within thirty days after removal.

\section{Giving Sub-Tenants the Beneft of the Exemption Law.}

478. There was a provision against a tenant assigning or sub-letting without the consent of the landlord, and it was held that a sub-tenant of a tenant, who has not been recognized as such by the landlord, cannot claim the benefit of the exemption law, as against a distress for rent. ${ }^{24}$ In view of this decision it may be to the interest of under-tenants to get the consent and approval of head landlords before leasing, and that they shall have the same rights to the exemption law as their landlords have. And lessees, in order to protect under-tenants, may provide in their leases that the right to the exemption shall extend to assignees or undertenants who may become such with the consent of the head. landlords.

\section{Providing for Surety in Cases of Extensions of Lease.}

479. In case of a person becoming surety for a tenant,

24 Rosenberg $v$. Hallowell, 35 Pa. 369. 
there is danger of the surety's denying his liability for extended periods, upon giving notice. To avoid such results the surety can be made to agree that his liability as surety shall extend, not only to the original term, but to any continuations or extensions thereof under or by reason of the lease.

A lease can provide that all renewals or extensions shall be upon the condition that the surety consents to be bound for the same.

\section{Getting the Consent of the Surety to Alter Lease.}

480. In case of an alteration of the terms of a lease without the consent of the surety, he may be discharged. Such consent had better be in writing.

Extension of Right to Terminate Lease to Assignees, etc.

48I. Have a right to terminate a lease to extend to grantees, assignees, devisees, heirs, executors, administrators, etc., if so intended.

There was a reservation in the lease by the lessor of the right to terminate the lease at any time by giving thirty days' notice. It was held that such reservation did not inure to the benefit of the lessor's grantees, there being no provision to extend this right to the grantees or assigns, as a number of other agreements in the lease had been made to extend to grantees and assigns. ${ }^{25}$

\section{Danger of Landlord Losing his Right to Rent by the Non-Perform- ance of an Entire Contract.}

482. Landlords, in renting property, should be careful, in case they promise to do something to the demised premises in the future, not to make their contract for performance entire. The plaintiff leased a warehouse to the defendants at an annual rent of $\$ \mathrm{I}, 500$, payable quarterly; at the time of the making of the contract he delivered to them possession of the

25 McClintock $v$. Loveless, 5 Pa. Dis. R. 417. 
three lower stories, and agreed to give them possession of the cellar and of the fourth and fifth stories on demand; he refused to deliver possession thereof, and the defendants were compelled for want of room to abandon the premises and to rent another house for the transaction of business. The plaintiff sued for use and occupation. The court held that the contract was entire, and being so, there could be no recovery unless complete performance had been prevented or waived by the party entitled to demand it. ${ }^{26}$ To the same effect is Block $v$. Dowling. ${ }^{27}$

Cautions in Preparing Agreements for the Extension of Term and for Options.

483. In case there is a lease for a certain term the tenant can go out of the demised premises and the landlord may enter without notice. Even in a case of a tenancy from year to year it has been held that the tenant can go out at the end of any year without notice. For mutual convenience leases often contain the following or a similar form:

"And it is hereby mutually agreed, that either party hereto may determine this lease at the end of said term, by giving the other notice thereof, at least prior thereto, but in default of such notice, this lease shall continue upon the same terms and conditions as are herein contained, for a further period of and so on from to unless or until terminated by either party hereto giving to the other notice for removal previous to the expiration of the then current term."

As questions may arise as to whether the provisions as to notice are to apply not only to the present but to future terms, it will be well if such is the intention to have the notice to terminate to expressly apply not only to the original term 
but to the termination of the second term, and to each future additional or extended term there may be, express or implied. It sometimes occurs that a tenant is given an option to continue for an extended term, certain or uncertain, and it appears that care should be exercised in the language of the lease giving such option.

The Supreme Court affirmed a judgment on the opinion of the court below. In that opinion it was said: "The lease was to continue 'for the term of one year with the privilege of three years from the first day of April, I885, at the rent of two hundred and four dollars per year.' We interpret this language to mean that the lessee could remain one year or from year to year, not exceeding three years. A privilege to remain three years must include the privilege to remain two years. The whole necessarily includes the parts. We must construe the lease in favor of the tenant rather than in favor of the lessor. In the absence of anything to the contrary the tenant, by giving due notice, such as was given, had the right to terminate the lease at the end of the second year; he exercised the option secured to him under the lease. The lease fixed the rent at two hundred and four dollars per year, indicating a term from year to year rather than a term for three years. The landlord cannot complain, for he received due notice of the intention to quit. It is argued that this interpretation destroys the mutuality of the contract, but we must remember that the contract starts out with granting a privilege in favor of the tenant." 28

In case a term can be extended at the option of the tenant it is suggested that there can be the usual clause that either party may terminate the lease on notice, say, on three months' written notice if a yearly tenancy, and that the tenant must give notice, say, three months and one week before the end of the term, whether or not he exercises the option. That if the option is not exercised the tenancy shall run on

28 Gillion $v$. Finley, 22 W. N. C. 124 (s. c.). 
from year to year unless either party gives three months' notice to terminate before the end of the term, as provided in the other clause. The tenant may not exercise an option for two years, but he may be willing to remain for another year as a tenant from year to year, and so on, and the landlord may also be willing, and a provision can consistently be made for the running on of a tenancy from year to year if the option is not exercised. Modern cases show considerable litigation as to agreements for extending leases and the exercise of options, and it will be well for the practitioner to carefully examine these cases and to steer clear of any mistakes. ${ }^{29}$

A lease provided "that if the said lessee should continue on the premises after the termination of the above contract, then the same is to continue in force for another year, and so on from year to year, unless either party shall give legal notice in writing to the other party of his intention to terminate said letting." It was held that as a tenant from year to year is not bound to give notice of his intention to quit at the end of the current term, the tenant, in this case, was not bound to give notice under the foregoing clause. Some printed leases have the word "legal" inserted. It will be well to see that the word is omitted to guard against the above decision. ${ }^{30}$

\section{Necessity of a Consideration for an Agreement to Change the Terms of a Lease.}

484. An agreement between landlord and tenant, made during the term, to modify the lease, is not binding until the end of the term without some new consideration; but it may be valid for any time subsequent to the expiration of the term; and the continuance of the tenant in possession paying the rent agreed upon would be sufficient consideration for the modification as to the subsequent time. Such a contract may

29 Lipper v. Bouve, 4I W. N. C. 566; Harding v. Seeley, 148 Pa. 20; Ashhurst v. Phonograph Co., I66 Pa. 357; Megargee v. Longaker, ro $\mathrm{Pa}$. Super. Ct. R. 49r; Rohbock v. McGargo, $6 \mathrm{~Pa}$. Super. Ct. R. I34.

30 Brown v. Brightly, I4 W. N. C. 497. 
be implied by the acts of the parties. Even if it be an express agreement, not binding in law, but supposed to be so by the parties and carried out by them; and if a new year be entered upon, under the supposition and intention that it is and should be mutually binding, such agreement will be entirely valid. ${ }^{31}$ In case of an agreement as to the amount of rent and other matter during the term, care should be exercised to have some consideration expressed.

\section{Protecting Landlord in Farm Leases.}

485. In farm leases it may be important for the landlord to have agreements incorporated in the lease, as to the management of a farm by the tenant. Notwithstanding there may be a custom concerning such management, it would be well to understand distinctly what the tenant is or is not to do in the way of farming. For example, there may be the usual clause against the tenant's removing things necessary for the nourishment of the land, against plowing, or for planting of crops and manuring.

Making the Payment of Taxes, Charges, etc., as Rent.

486. In case the tenant is required by the lease to pay taxes, water rent, for light, or for power and the like, it will be well to have a provision that such payments shall be paid as rent. and that they can be treated and distrained for as rent. It may be well to have fixed charges for such payments, with fixed times of payment. so that the landlord can distrain for certain amounts in such cases; but where this is not done, the maxim that "that is certain which can be rendered certain" will apply.

Necessity of Reading Leases.

487. Before leases are executed. the parties should read them or have them read.

It has been said: "If a party who can read will not read a

3 I Walker $v$. Githens, 32 W. N. C. 505. 
deed put before him for execution; or if, being unable to read, will not demand to have it read or explained to him, he is guilty of supine negligence. This is undoubtedly true where the parties stand on an equal footing and deal at arms' length."

\section{Protecting Fire Insurance from Conduct of Tenant.}

488. Sometimes insurances are affected by renting to tenants, or by tenants making alterations or putting in or using things prohibited in the policy.

A shoe store was changed into a dry goods, hardware and grocery store, in which a keg of powder was placed. The occupation of grocer and storage of gunpowder were prohibited. There was a loss by a fire in the grocery store, and an explosion of the powder. It was held the insurance company was not liable; that it was not material that the landlord did not know that his tenant kept gunpowder; that forbidden articles in a policy of insurance would be of no practical importance if the effect of keeping them depended upon the landlord's knowledge that they were kept by his tenant. $^{\mathbf{3 2}}$

In renting properties for business, or consenting to assignments, or an underletting, it would often be well to examine the policies of insurance to see if the business of the proposed tenant is prohibited. If the business is found to be so, perhaps the insurance companies will allow the business for an additional premium. It would also be well to insert an agreement of the lessee, that he will not, on penalty of instant forfeiture, occupy or permit the demised premises to be occupied excepting for a particular business, and that he will not, knowingly, do or commit, or willingly suffer to be done or committed, any act or thing contrary to the conditions or stipulations of the policies of insurance on the premises. Of course, it will have to be proved that the tenant had notice in

32 Fire Assn. v. Williamson, $26 \mathrm{~Pa}$. 196. 
some way of such conditions and stipulations. Unless something of this kind is done, a tenant, assignee, or any undertenant, may, at any time, imperil the insurance.

\section{Distinguishing Between a Lease and Sale in Granting Mining Rights.}

489. In Pennsylvania there has been much confusion and litigation under the laws relating to mining rights or leases. It has sometimes been a difficult question to determine whether there is a sale of ore in a mine, or whether there is a lease. In such instances the question becomes important because of the differences between a sale and a lease.

If there is a sale, rights are given to the purchaser similar to those he obtains under title as the purchaser of a piece of land. Ore or coal is a portion of the land, and not produce. A purchaser may hold the right to ore as to a piece of land, yet another person may own the soil above. In case of a sale, there should be a deed executed by the proper parties, and recorded, so as to give notice; although the purchaser being in possession of the mine possibly may give notice. If full ownership is intended, the word "heirs" had better be used. In case of a conveyance of the ore, the title to it will belong wholly to the purchaser, as real estate. If royalties or other amounts are to be paid in the future, they will be in the shape of purchase-money. In case the vendor shall die, the mine or ore will not belong to his estate. The unpaid purchasemoney will not go to the heir or devisee as rent, but to the executor or administrator, like any debt due to the estate. Testators may happen to die under the impression that they own the mine, and that there was a lease. In consequence, blunders may be made in wills for which there will be no remedy.

If there is a lease the landlord will retain the ownership of the coal or ore until it is separated by mining; and he will have what is called a reversion-that is, the right to the possession of the property at the end of the term of the lease. 
In case the lessor dies, the rent or royalty falling due after his death will go to his heir or devisee, and not to his executor or administrator. In case of a sale, the purchaser will pay taxes on the mine; but in case of a lease, the lessor will be liable to pay the taxes.

In case a person bargaining for a mining property is to have an unlimited right to take all of the coal or ore for a price, there will be a sale. The principle leading to such a result seems to be that where there is the right to take the whole product of the piece of land, the effect is the same as if there was an express grant of the land. What has led to mistakes and disastrous results is this: that there can be a sale or grant of coal in place, although there may be nearly every indication of a lease. The document may be entitled a lease; the words, "demised" or "rented," may be used; there may be a term of years; there may be amounts to be paid called "rent"; there may be provisions against assigning or underletting, and of forfeiture for non-payment and the like -and yet, because of an indication that the grantee is to pay for all of the coal, whether mined or not, there will be a sale, and often so contrary to the real intention of the vendor.

If there be a provision in the lease that the grantee shall mine a certain amount of coal per annum, and if he do not, that he shall pay a certain amount of money per annum, that circumstance may result in a sale. Such clauses are probably put in what are supposed to be leases as a spur to urge a supposed tenant to diligence in mining. In order to avoid mistakes in drawing grants or leases of mining rights, the following suggestions are made:

In case the owner of a mine, after explanation, should see fit to sell and convey all of the coal or ore in a mine, let there be a deed made in the manner used when a piece of land is conveyed, the words, "grant," "bargain" and "sell," etc., being used instead of such words as "leased," "demised," etc. Let the deed express the fact that it is the intention to sell the mineral, and not to lease it. The coal or ore can be 
granted for a sum of money payable at once or in instalments, or there can be a provision that the purchaser shall mine continuously and pay a certain proportion of the product of the mine as purchase-money. The deed should be signed by the proper parties, exactly as in the case of conveyance of real estate. Married women should join in the deed with their husbands; minors' interests should be sold under order of the orphans' court; the deed should be acknowledged and recorded.

If life tenants hold title, and the mine is not opened, they themselves will have no right to. open mines, and, consequently, they cannot convey or lease to others any right to open mines.

The question has arisen in the mind of the author as to whether or not the vendor will be secured the payment of the purchase-money. The payment of the purchase-money can be charged upon the mine in the deed of conveyance; and, in such case, a sale of the mine can be made to secure the charge by equitable ejectment or by judgment against the owner of the mine. It is not customary to charge a mine expressly with the payment of the purchase-money, and it may be doubtful whether or not there will be any charge without such expression. The best way to secure purchase-money would probably be by a purchase-money mortgage. Such mortgage may be made to bind, not only coal or ore in place, but minerals severed by mining. As to coal or ore severed by mining, however, there may be doubts as to whether the mortgage would not be void as to creditors, although it may be good between the parties.

If there is to be a lease of coal or ore, then the paper should be styled a lease, and should have all of the features or indications of one; and, particularly, there should be a term, leaving a reversion in the landlord. The lease can expressly declare that there is to be no sale or conveyance of the coal, but only a lease. The lease can also declare that the ownership of the coal or ore in place shall remain the property of 
the landlord until severed by mining. Above all, the lease should guard against granting to the tenant all the minerals, or in requiring him to pay in any way for all the minerals. If the rent is to be paid in the form of royalties, it will be best to have the payments made from a portion of the coal mined. The lease can provide, as usual, that the tenant shall mine continuously; and there can be a clause of forfeiture for failure to do so.

If the land is unoccupied by the lessor, and only valuable for mining, then it will be well to lease the land with the right to mine. It was held that in order to constitute a lease, it is not necessary that the lessee should have an interest in the surface. ${ }^{33}$ In the mining districts leases of lands for mining purposes are restricted to the use of only so much of the surface as will be necessary for mining purposes, with the right in the lessor to use the remainder of the surface. An agreement that a person shall for a term enter on the land, dig ore, erect buildings, etc., and pay, say fifty cents a ton, for all ore mined, amounts to a lease.

The following cases draw distinctions between a sale, lease and license for the purpose of obtaining minerals:

There was a demise of land for a term of years with the sole and exclusive right and privilege, during said period, of digging and boring for oil and other minerals, and of gathering and collecting the same therefrom. The Supreme Court said: "The contract referred to was a lease of the lands for a specified term and for a particular purpose, at a fixed rent or royalty reserved out of the production." It was "not a mere license, as in Funk $v$. Haldeman, 53 Pa. 229, for in that case the words of the grant amounted neither to a lease nor a sale of the land, nor of any of the minerals in the land. Funk's right was, therefore, declared to be a license to work the land for minerals, a license coupled with an interest which the licensor could not revoke. Nor does the act of February

33 Sheets $v$. Allen, $89 \mathrm{~Pa}$. 47. 
3, I882, import a sale of all the coal, gas and other minerals in the land, absolutely; the cases of Caldwell $v$. Fulton, $3 \mathrm{I} \mathrm{Pa.}$ 476; Sanderson $v$. City of Scranton, 105 Pa. 469, and others involving the same principle, do not, therefore, have any application." $\mathbf{3 4}$

There was an agreement whereby one gave a defendant the sole right to quarry, take and sell stone for a term for which he was to pay a certain amount per annum. The Supreme Court said: "The agreement between Cooper and defendant granted the latter the sole right to quarry, take and sell ganister stone from a certain tract of land for the term of fifteen years. Without going into the niceties of distinction between licenses, chattel interests and sale of minerals in situ, as sales of the land, it is sufficient for the present case to say, while the grant from Cooper to defendant was more than a license, because it passed an exclusive interest in the land for a certain purpose for the specified term, it was less than a sale, for the term was limited, and stone not actually taken would remain part of the land and revert to the lessor at the end of the term. It was, therefore, a lease, a chattel interest within the case of Brown $\%$. Beecher, I20 $\mathrm{Pa}$. 590." 35

In connection with the practical questions here considered, it will be well to read Chapter XXIV, on Mining Leases.

\section{Necessity of a Particular Description of the Extent of a Right to Mine.}

490. There was a tract of two hundred acres, on which coal had been mined at several openings. The lease described the thing granted by the lessors no otherwise than as their "coal-bank." It was said that the lease ought to have been drawn so as to exclude dissension: that it was for the jury to say what was the extent of the demise. Words

34 Brown v. Beecher, I20 Pa. 590.

35 Duncan $v$. Hartman, $143 \mathrm{~Pa} .595$. 
enough were not put into the instrument to define the boundaries of the grant. ${ }^{36}$

\section{Ascertaining if any Old Mining Leases are Outstanding.}

49I. It is customary in mining leases to have agreements for the forfeiture of the lease for the non-payment of royalties, or for the non-performance of certain things to be done by the tenant. The forfeiture will depend upon the election of the landlord, as the provision for such forfeiture will be for his benefit. It sometimes happens that tenants, after making attempts to find minerals, or to mine, abandon the demised premises; and if there is any evidence of previous mining, inquiry should be made of the landlord as to whether or not he has exercised his right of forfeiture. If he has not, there may be an outstanding tenancy that will make the title of the new tenant defective.

Protection to Landlord who Reserves the Surface in a Lease to Mine.

492. In case a lessee has a right to mine he can open mines so near to the lessor's dwelling-house, to a spring, or to a stream, as possibly to do damage, for which there will not be remedy. Mine owners have the right to pollute streams in mining, and that in some cases should be considered. The right to open and work mines may be restricted to certain localities so as to avoid such damage.

\section{Binding Remainderman in Case of a Lease by Tenant for Life.}

493. A lessor having a life estate made a coal lease in which it was stated that "All covenants herein bind executors, administrators and assigns." The lessor having died, the representatives and heirs of the lessor executed an instrument in writing, providing that the lessee should not be dispossessed until the end of the term, and it was held that 
the lessee had no right to have the lease cancelled upon the death of the lessor. ${ }^{37}$

In taking a lease from the owner of a life estate, if those entitled in remainder join in the lease in renting the property for a certain term, the rent to be paid to the tenant for life during his life and then to those entitled in remainder, it seems as if the remaindermen will be bound according to the above authority. In such case it will be well to have the lease acknowledged and recorded, so as to give notice to purchasers or mortgagees of the remaindermen. It can be agreed that in case the remaindermen, their heirs or assigns, shall not be bound by the lease, that it shall cease.

\section{Necessity of Recording Oil Lease when Tenant does not Take Pos- session.}

494. If a tenant does not go into actual possession or occupation and his lease is not recorded, his title may be cut out by that of a subsequent purchaser for value without notice. $^{38}$

\section{Necessity for Having Time Fixed for Delivery of Landlord's Share of Crops.}

495. Rent reserved for a farm was one-half of all the crops raised thereon. The lease did not indicate in terms when the rent should be paid. As there was no covenant to pay at any particular time, it was held that the end of the year was the period which the law assigned for the annual reditus to the landlord. The crops were severed from the ground, and it was held that the fact that the grain had been severed prior to a sheriff's sale of the farm, but not delivered to the landlord, did not vest the title to the grain in him as against the sheriff's vendee. ${ }^{39}$

The lease can provide that the delivery of the crops shall be due to the landlord upon severance, and then they should

37 Gas Co. v. Patterson, 184 Pa. 364.

38 Aye $v$. Phila. Co., $193 \mathrm{~Pa}$. 457.

39 King $v$. Bosserman, I3 Super. Ct. R. 480. 
be delivered. In coal oil and gas leases they may possibly be treated like farm leases as to questions when productions mined are due to the landlord.

In case of a private sale, and the crops not being due until the end of the year, the vendee may become entitled to the crops although harvested unless the vendor reserves such crops in the agreement of sale. ${ }^{40}$

\section{Protection of Parties in Agreements to Pay for Taxes, Charges, Assessments, etc.}

496. In case a tenant agrees to "pay taxes, water rents and assessments upon the premises" he will have to payfor paving and curbing a street opposite the demised premises and he possibly would not agree to do so. When tenant is to pay taxes, gas, water rent, etc., he has to pay the parties entitled to receive payment. ${ }^{41}$

A lease can provide that in case temant does not pay such claims, the landlord can treat the amounts unpaid as rent and collectible by distress, and that the agreement to pay shall extend to and bind the assigns of the parties.

\section{Dangers in Using Clause that Landlord may Change Terms of Lease.}

497. In the city of Philadelphia and, it may be, elsewhere in Pennsylvania, the following form has been used extensively:

"And it is hereby mutually agreed, that either party hereto may determine this lease at the end of said term, by giving the other notice thereof, at least

prior thereto, but in default of such notice. this lease shall continue upon the same terms and conditions as are herein contained, for a further period of and so on from to

unless or until terminated by either party hereto giving to the other notice for removal previous to the expira-

40 King 2 . Bosserman, $8 \mathrm{~Pa}$. Dis. 344.

4I Hand $v$. Suravitz, $148 \mathrm{~Pa} .202$. 
tion of the then current term. Provided however, that if the lessor shall have given notice previous to the expiration of said term, or any extension or renewal thereof as above, of intention to change the terms and conditions of this lease, and the lessee shall hold over after such notice he shall be considered lessee under the terms and conditions mentioned in such notice, for such further period as he may remain in possession of said premises, and until this lease is terminated by notice as hereinbefore provided."

It seems that care should be exercised in filling in the form. or its use. For an instance, a lease was prepared for a tenant to sign in which the blanks were filled in so that either party could terminate the lease upon three months' notice before the end of the term, but so that the landlord could change the terms of the lease upon ten days' notice before the end of the term, and if the proposed lessee had signed the lease the result would have been that the lessee could have been compelled to vacate on ten days' notice by the lessor so changing the terms that they would not be accepted by the lessee. Even supposing the lease should provide that the notice to change the terms should be given three months before the end of the term, and the notice by lessor should be given at the last hour, there may be a question whether according to the reading of the form the lessee would not be in for another year with changed terms because he had no opportunity to give and had not given notice to terminate the lease at the end of term three months before its termination.

\section{In Case of Doubtful Construction, the Tenant Favored.}

498. The rule of law respecting leases of doubtful duration is, they must be construed favorably to the tenant. If the duration is left optional by the terms of the lease. without saying at whose option, as for instance. if a lease be made for seven, fourteen or twenty-one years. it means at the option 
of the tenant who has the right of choosing whether he will put an end to the lease at the end of seven years, or continue it for fourteen or twenty-one years. And in all cases of uncertainty, the tenant is most favored by law, because the landlord, having the power of providing expressly in his own favor, has neglected to do so; and on the principle that every man's grant shall be taken most strongly against himself. ${ }^{42}$

In view of the above principle of construction the landlord should be careful to see that his lease is entirely free from doubt, and in doing so the aid of counsel should be obtained in every important lease.

Fixing a Time for the Tenant to Perform an Agreement to Make Improvements.

499. In case tenant agrees to make improvements he can do so at any time during lease.

There was a lease for five years with privilege of a ten years' lease. The tenant was to improve, and it was held that the lessee could make the improvements at any time during the lease. ${ }^{43}$

There may be a case where it will be to the interest of the landlord that the improvements shall be made before the end or near the end of the lease. If the tenant has the whole term in which to improve he may happen to break his agreement near the end of the lease and go out without improving, and the landlord may have no redress but in action for damages, which may be useless.

\section{Protecting Landlord's Right to Tenant's Fixtures at the End of the Lease from Levy, etc.}

500. If there be an agreement between the landlord and tenant that the fixtures of the tenant are to become the property of the landlord at the end of the lease, such fixtures may be levied upon in the meantime. ${ }^{44}$

42 Com. v. McNeile, 8 Phila. 438.

43 Palethrop v. Bergner, $52 \mathrm{~Pa}$. 149.

44 Lemar v. Miles, 4 Watts, 330. 
It is suggested that the landlord possibly may be protected by a provision in the lease that in case of a levy upon such fixtures the title and ownership thereof shall vest in the landlord immediately before the issuing of any execution or attachment against the tenant, subject to any rights of the tenant to use the same during his lease. Under such circumstances delivery to the landlord would not be necessary.

\section{If an Assignee Assigns his Lease and Retains an Interest He will Remain Liable.}

50I. The privity of estate which induces the liability of the assignee is the actual or beneficial enjoyment of the premises. It is not necessary that the legal title shall be, or shall continue, in him who is to be held because of his privity of estate. One who has a beneficial interest in the estate created by the lease, or enjoys the profits thereof, or has a right to enjoy such profits, is in privity of estate, as the successor to the title of the lessee. When the assignee of a leasehold estate executes a lease of the premises, reserving a larger rent or containing covenants more advantageous than those found in the original leasehold, he reserves to himself a benefit under the original lease, and his privity of estate is thus continued. ${ }^{45}$

In case an assignee assigns his lease he should be careful not to retain any interest in the demised premises or in the rents and income thereof in any way or manner, directly or indirectly.

\section{Necessity of Having a Clause for Forfeiture for a Breach of a Covenant Not to Assign.}

502. The fact that an assignment of a lease is in violation of a covenant therein does not prevent the passing of the title. $^{46}$ In view of this consequence it becomes important that the landlord should have the right to terminate the lease for such a breach, as otherwise he may have only a right to 
an action for danages which may prove fruitless. In assessing damages for a breach of covenant not to assign it is considered in how much worse position the plaintiff will be than he would have been in if he had retained the defendant's liability. ${ }^{47}$ As to the assignor's liability, he will remain liable although he assigns, and the landlord financially may be in the same and, perhaps, a better position, and if so, how can there be any damages recovered?

Guarding Against the Breach of Trifling Covenants Giving the Right to Recover Possession.

503. It seems that in justice to a tenant he should have reasonable notice to perform trifling covenants before the landlord can recover possession. In a lease commonly used, if the tenant does not keep the premises in good order and repair, and remove ashes, rubbish or refuse matter therefrom the lease shall determine and the landlord may recover possession. It will not do to argue that a breach in such case is a small matter. Landlords generally tolerate such violations of a lease, but it is not safe always to rely upon such conduct. If a landlord should desire to break a lease he may be tempted to take every advantage allowed by the law.

\section{In Case a Tenant Agrees to Use or Not to Use Demised Premises for a Certain Business or Purpose.}

504. A lessee under a lease containing a covenant that under penalty of forfeiture he would neither occupy nor permit the premises to be occupied otherwise than as a saloon or dwelling, without the lessor's written consent indorsed. was not released from liability for the rent by a failure to obtain a license to sell liquors. ${ }^{+8}$ This case, shows a danger there may be in a person renting a property for only a certain business or use and then discontinuing the business or the use provided. When there is a restriction as to a business it 
should be broad enough so that the tenant can get another person to take his place in case he should vacate.

Danger of there being a Breach of a Covenant Not to Assign Lease by Taking a Partner.

505. Case of tenant taking a lease with a covenant not to assign and then taking a partner: Where a partner of the lessee, on a dissolution, becomes his successor in the business, and continues to occupy the demised premises, and the lease contains a clause against an assignment without the consent of the landlord, such continuing partner will be deemed as assignee of the term. ${ }^{49}$

It may occur that an individual tenant may take a partner and assign to him a right in the lease, and in such case it may be well to have the prohibition against an assignment, with the provision that the tenant may take a partner and give him a right in the lease. For safety, if there is no such clause, the consent of the landlord to the assignment had better be procured.

\section{Necessity for a Description to Locate Premises in Leases or Amicable Ejectments.}

506. An amicable action with confession of judgmnt upon a lease was entered for premises No. I 36 South Third Street, in the city of Philadelphia. The case appears to have been taken to the Supreme Court by a writ of error without any intermediate rule. There was an objection that the description was too indefinite, but the Superme Court affirmed the judgment, because the street number alone indicated the premises. $^{50}$ The question arises: Supposing no street number had been given, what would have been the result? The act of 1806 requires a description to be filed in proceedings in ejectment.

The safe practice is to describe the land so that the sheriff

49 McAdam on Landlord and Tenant, 285.

50 Flanigan $v$. The City, 5I Pa. 49I. 
can execute the writ without difficulty and with no extrinsic aid or explanation. ${ }^{51}$ It is suggested that it will be well to give the street number, if any, in a lease, or to give some description that will particularly locate the demised premises. If this is not done it will be well for the amicable action and writ of execution to define and locate the premises, as it is not known how the courts will decide in case objection is made.

\section{Giving Right to Distrain Off the Demised Premises.}

506*. At common law a landlord could not distrain goods off the demised premises. By the act of March 2I, I772, ${ }^{52}$ if a tenant should fraudulently or clandestinely remove his goods from the demised premises to prevent the landlord from distraining, the landlord, within thirty days after the removal of goods, may follow and distrain upon them, if they should not be sold. By the act of March $25,1825,{ }^{53}$ and a supplement thereto, if goods should be fraudulently removed in Philadelphia, Pittsburg or Allegheny to prevent a distress, the rent can be apportioned to the date of removal and goods can be followed and distrained upon an affidavit being made as to fraudulent removal. It was held as to the first act that a mere removal in the claytime, without the knowledge of the landlord, would not be fraudulent; that the landlord must be vigilant, and if he should neglect to distrain when the rent becomes due he will lose his remedy under the act. ${ }^{54}$ A lease contained a clause reading as follows: "And it is further agreed, that should the property of the lessee be removed from the aforesaid premises, the lessor is hereby authorized, at any time within ninety days thereafter, to enter upon the same wherever found, and to seize and sell so much thereof as will fully satisfy him, the said lessor, for all arrears

5I I Brewster's Practice, 363.

52 Act of March 21, 1772, I P. \& L. Dig. 2638; I Sm. L. 370.

53 Act of March 25, I825, I P. \& L. Dig. 2639; P. L. Ir4.

54 Grace $v$. Shively, 12 S. \& R. 216; Grant's Ap., 44 Pa. 477. 
of rent then due or to become due, as above provided, and the costs thereon." The court of common pleas of York county, in considering this clause, said: "Can it mean a removal to which the landlord consents, if that be the fact, or can it mean any other than a fraudulent or clandestine removal? Without deciding a question which, on this motion; has not arisen, it looks as if it must be construed to mean a fraudulent or clandestine removal, and if it was neither, but with the knowledge and consent of the landlord, then it is not effective, and no levy could be made under the landlord's warrant, and the plaintiff would not have been injured by the conduct of the defendant under it: Owens $v$. Shovlin, I I6 Pa. 37I." 55 From the narrow construction of the act of I 772 by the decisions, such clauses as that above stated have been commonly inserted in leases. According to the letter of such clauses, after a removal at any time, by day or by night, with or without the knowledge of the landlord, the goods removed can be levied upon at any time. The words being plain and leading to no absurdity, there is no room for construction or to incorporate by implication the words "fraudulently" or "clandestinely." In construing the contract the acts of assembly can have no application further than this: that the acts were narrow and such clauses were made broader, omitting the words "fraudulently" or "clandestinely." In treating the clauses in question as the acts of assembly there would be a violation of fundamental rules of construction. The plain words of the lease would be disregarded, and, above all, the intention of the parties would not prevail. Owens $v$. Shovlin, quoted in Baer $v$. Kuhl, has no application to the question considered. There was a provision for a distress in case of a tenant's removal from the premises, but there was no provision for following and distraining upon goods removed. A lease was for a store room for two years, for the yearly rent of $\$ 2,000$, 
with the stipulation that if the lessee should "at any time during the continuance of this lease, attempt to remove or manifest an intention to remove his goods and effects out of or off the premises, without having paid in full for all rent which shall become due during the term of this lease, then the whole rent for the whole term shall be taken to be due, and the lessor may proceed to distrain and collect the whole as if by the conditions of the lease the whole rent was payable in advance." It was held that by the lease it was not required that the attempt or intention to remove the goods should be fraudulent in order to authorize a distraint. ${ }^{56}$ This case shows the great liberality of the courts in allowing persons generally to make their contracts regardless of results or hardships. Considering the doubts which have arisen, as above indicated, it is suggested that the clauses in question can provide for the apportionment of the rent to the date of the removal of goods, or to have rent fall due in advance; and to give the right to distrain. whether the removal may be by day, by night, fraudulent, with the knowledge or consent of the landlord or otherwise. The right to distrain on goods removed, with the rent apportioned to the date of removal, with the right to recover possession for non-payment of rent by an amicable ejectment, would be sufficient generally to protect a landlord. To go further than this and to have the whole future rent to fall due, if of considerable amount, seems morally wrong, though, like Shylock's bond, it may be legally right.

56 Goodwin v. Sharkey, 80 Pa. I49. 


\title{
CHAPTER XXVI.
}

\author{
FORMS.
}

PAge 238.

SECTION

507. A lease.

508. Farm lease.

509. Farm lease on shares.

510. Farm lease on shares, short form.

5II. Covenant that lessee shall fallow the land and now but once a year, etc.

512. Covenant that lessee may dispose of hay and straw.

513. Covenant to lay down part of the ground with clover, etc.

5I4. That the lessee shall use the hay, dung, etc., on the premises.

5I5. Fire clause for farm lease, No. I.

516. Fire clause for farm lease. No. 2.

517. Fire clause for a dwelling.

518. Fire clause for a business property.

519. To protect against assignment of lease.

520. For insertion after ejectment clause.

52r. Giving an option to purchase.

522. Surety for tenant.

523. Assignment of lease.

524. Surrender of lease.

525. Distress warrant.
SECTION

526. Notice of distraint.

527. Affidavit of appraisers and appraisement.

528. Consent of tenant to permit distrained goods to remain.

529. Notice of constable's sale.

530. Claim for benefit of exemption law.

531. Summons of appraisers.

532. Affidavit of appraisers and election.

533. Appraisement of exempted goods.

534. Amicable action and judgment in ejectment.

535. Notice to quit for non-payment of rent under act of 1830.

536. Complaint.

537. Summons.

538. Writ of restitution.

539. Record.

540. Notices to quit at end of lease.

541. Complaint for possession under act of 1772 .

542. Precept to the sheriff.

543. Inquisition.

544. Record.

545. Summons to third party claiming title. 
SECTION

546. Complaint for possession under act of 1863 .

547. Summons.

548. Record.

549. Writ of restitution.
SECTION

550. Notice in case of lost lease. 551. Second notice.

552. Notice when tenant is unable to answer first notice.

\section{A Lease.}

507. This Agrement Witnesseth, that A. B., of doth hereby let unto $C$. D. [here describe premises] for the term of one year from the first day of January A. D. nineteen hundred, at the rent of three hundred dollars per annum, to be paid montlly in advance, the first monthly payment thereof to be made on the first day of January, Anno Domini I900, and said lessee doth hereby agree to pay said rent to the said lessor on the days and times aforesaid, at the of the said lessor, or at such other place within as said lessor may in writing from time to time direct, without demand being made therefor, and that he will not assign this lease, nor underlet the said premises, or any part thereof, or use or occupy the same other than as a without the written consent of the said lessor first had and obtained, and during the said term will keep said premises in good condition, order and repair, and at the termination of said term or of any extended term, will deliver up the said premises in as good condition, order and repair as they now are, reasonable wear and tear, and loss or damage by fire or other casualties, excepted. And the said lessee further agrees that if the rent shall remain unpaid on any day on which the same ought to be paid, then the lessor may enter the premises, and proceed by distress and sale of the goods there found, to levy the rent and all costs and officer's commissions. The said lessee further agrees that all goods on the said premises, and for thirty days after removal, shall be liable to distress for rent, and hereby waives the benefit of all exemption laws in relation thereto. And said lessee further agrees that this waiver shall extend and be applicable to any process, execution or executions that may be issued in any or all suits, actions or proceed- 
ings, for the collection of rent due and in arrear, and for damages for the non-fulfilment of any of the covenants herein contained. And it is hereby mutually agreed, that either party hereto may determine this lease at the end of said term, by giving the other notice thereof, at least

prior thereto, but in default of such notice, this lease shall continue upon the same terms and conditions as are herein contained, for a further period of one year and so on from year to year unless or until terminated by either party hereto giving to the other notice for removal previous to the expiration of the second or any succeeding, current, additional or extended year or term under said lease, expressed or implied.

All rights and liabilities herein given to, or imposed upon, either of the parties hereto, shall extend to the heirs, executors, administrators, successors and assigns of such party.

In witness whereof, the said parties have hereunto set their hands and seals, this day of , one thousand nine hundred.

Sealed and delivered in the presence of

SEAL.

SEAL.

NotE.-The above lease can have clauses inserted according to the circumstances, such as the following: To remove rubbish; to pay for light, heat or power as rent; for amicable ejectment proceedings to recover possession for not performing the terms of the lease; for the landlord to enter the demised premises for examination; a fire clause; for sign rights; for rights of way; for elevator rights, etc. In case the tenant's ownership shall be transferred by operation of law, such an event may be made a ground for recovering possession of the premises.

\section{Farm Lease.}

508. This Agreement Witnesseth, that A. B., of doth hereby let and demise unto C. D. [describe farm], for the term of three years from the first day of April, A. D. nineteen hundred, at the rent of six hundred dollars per annum, to be paid quarterly in advance by the lessee at the 
such place as the lessor or any subsequent owner may require; the first quarterly payment thereof to be made on the first day of April, I900, which said rent the said lessee doth hereby agree to pay to the said lessor on the days and times aforesaid, and that he shall not nor will assign this lease nor. underlet the said premises, or any part thereof, or use or occupy the same other than as a farm, without the written consent of the said lessor first had and obtained, and shall and will during the said term keep, and at the termination thereof deliver up, the said premises in as good order and repair as they are now in, reasonable wear and tear and casualties which may happen by fire or otherwise only excepted. The lessee agrees as follows, viz.: That he will use on the said premises all the hay, straw and fodder which shall be grown thereon; that he will not sell, assign, pledge, remove or cause or suffer to be removed any of the dung, manure or compost made or which shall be on said premises, and that he will use and spread the same thereon at propertimes and places for the nourishment thereof, and that upon the termination of this lease or any subsequent letting thereunder he will leave upon the said premises any remaining hay, straw, fodder or manure, which shall then become the property of the lessor; that he will not convert into tillage or garden ground any of the pasture or meadow ground; that he will not mow any of the meadow or pasture ground more than once in any one year; that he will not cut down or use any of the trees upon the said premises; that he will mow or keep down in the usual manner, thistles, docks and other seeding weeds; that he will keep the fences in good repair, the lessor furnishing such materials for the purpose as he may think necessary; that he will cultivate the said farm with respect to crops and in every respect according to the usual. course and custom of good husbandry, sowing winter grain with a sufficient quantity of timothy and clover seed. And if the rent shall remain unpaid on any day on which the same ought to be paid, then the lessor may enter the premises, and proceed by distress and 
sale of the goods there found, to levy the rent and all costs and officer's commissions. The said lessee further agrees that all goods on the said premises, and for thirty days after removal shall be liable to distress for rent and hereby waives the benefit of all exemption laws in relation thereto or to any execution. And it is hereby mutually agreed, that either party hereto may determine this lease at the end of the said term, by giving the other notice thereof, at least three months prior thereto, but in default of such notice, this lease shall continue upon the same terms and conditions as are herein contained, for a further period of one year and so on from year to year unless or until terminated by either party hereto giving to the other three months' written notice for removal previous to the expiration of the second or any succeeding or extended term under this lease, express or implied. And it is further agreed, that if the lessee shall die or if there shall be any involuntary assignment of this lease by law or otherwise, or if the said rent shall at any time be in arrear and unpaid, or if the said lessee shall underlet or otherwise use the said premises than as above expressed, or shall fail to comply with the conditions of this lease or shall not well and truly perform and fulfil all and every the covenants and agreements herein contained on the part of the lessee to be performed and kept, then this lease shall, at the option of the said lessor, cease and absolutely determine, and any attorney may immediately thereafter, as attorney for the said lessee, at the sole request of the said lessor, sign an agreement for entering in any competent court, an amicable action and judgment in ejectment (without any stay of execution or appeal) against the said lessee and all persons claiming under said lessee for the recovery by the said lessor of possession of the hereby demised premises, without any liability on the part of the said attorney, for which this shall be a sufficient warrant; and thereupon a writ of habere facias possessionem may issue forthwith without any prior writ or proceeding whatsoever, and the lessee hereby releases to the lessor all errors and defects 
whatsoever in entering such action or judgment, or causing such writ of habere facias possessionem to be issued, or in any proceeding thereon, or concerning the same; and hereby agree that no writ of error or objection or exception shall be made or taken thereto; and a copy of this lease verified by affidavit, being filed in said action, it shall not be necessary to file the original as a warrant of attorney, any law or rule of court to the contrary notwithstanding. No such determination of this lease, nor taking or recovering possession of the premises, shall deprive the lessor of any other action against the lessee for possession for rent or for damages.

It is mutually agreed that this lease shall extend and apply to and bind the respective heirs, assignees, devisees, executors and administrators of the lessor and lessee and all covenants, agreements, conditions and provisions herein shall apply to and bind the owner of the lease or demised premises as if the same ran with the land or as if they were original parties and the lessee agrees that no objection shall be made to the said ejectment proceedings by reason of rent not having been demanded or collected when due or by any waiver.

In witness whereof, the said parties have hereunto set their hands and seals, this day of one thousand nine hundred.

Sealed and delivered in the presence of

SEAL.

SEAL.

\section{Farm Lease on Shares.}

509. This Agreement Witnesseth, that A. B. doth hereby let and demise unto $C$. D. [here describe the farm with buildings] for the term of one year from the first day of April, A. D. nineteen hundred; the said C. D. to yield and pay unto the said A. B. one-half part of all the grain which shall be raised or grown upon the said premises, and which letting is to be according to the following agreements:

The said C. D. shall plant crops and cultivate the farm as 
follows [state how fields are to be planted; what crops are to be sown; how much winter grain, etc.]. Each party is to find and pay for one-half the seeds for crops. The said C. D. is to find and pay for all farming implements, all the working stock, all the necessary labor and all the other expenses in working and cutivating the farm and is to work the farm diligently in a husband-like manner. The said C. D. is to have the right to keep and feed not more than horned cattle and horses; the products of the dairy and garden products are to be for the exclusive use and benefit of the said C. D. The manure, hay, straw and corn which shall be grown upon the premises and all manure made thereon shall belong solely to the said A. B., but the same shall be used upon the farm for its nourishment, but any part thereof which shall not have been so used shall belong to the said A. B. The said A. B. shall have the right to store in the farm buildings his share of the crops, and the said A. B. reserves the right of entering and visiting the said farm and the farm buildings, to inspect the farming operations, receive, take care of and dispose of his share of the grain. The said C. D. shall keep the fences up and in good order and repair at his own expense; keep down the weeds and preserve all trees and timber. It is agreed that there shall not be any partnership between the parties hereto; and it is hereby mutually agreed that the said A. B. shall have the ownership of one-half part of all the grain sowed when in the ground and until it shall be divided and that all crops shall be cut and harvested in due season by the said C. D., and that there shall be a division between the said A. B. and C. D. of their shares of the grain upon such harvesting. And the said lessee doth hereby agree to pay the said rent to the said lessor and deliver to him his share of the said grain at the time aforesaid, at or in said barn or at such other place, within said as said lessor may in writing from time to time direct, without demand being made therefor, and that he will not assign this lease nor underlet the said premises, or any 
part thereof, or use or occupy the same other than as a farm without the written consent of the said lessor first had and obtained, and during the said term will keep said premises in good condition, order and repair, and at the termination of said term will deliver up the said premises in as good condition, order and repair as the same now are, reasonable wear and tear and casualties which may happen by fire or otherwise excepted. And the said lessee further agrees that if the rent shall remain unpaid on any day on which the same ought to be paid, then the lessor may enter the premises and proceed, by distress and sale of the goods there found, to levy the rent and all costs and officer's commissions. The said lessee further agrees that all goods on the said premises, and for thirty days after removal, shall be liable to distress for rent and hereby waives the benefit of all exemption laws in relation thereto. And said lessee further agrees that this waiver shall extend and be applicable to any process, execution or executions that may be issued in any and all suits, actions or proceedings, for the collection of rent due and in arrear, and for damages for the non-fulfilment of any of the covenants herein contained. And it is further agreed, that if the said rent or grain shall at any time be in arrear and unpaid or undelivered, or if the said lessee shall underlet said premises or any part thereof or assign this lease, or in case of an assignment of the lease by operation of law, or if he shall use the said premises otherwise than as above expressed and provided, or shall not well and truly perform and fulfil all and every the covenants and agreements herein contained on the part of the lessee to be performed and kept, or in case the lessee shall die; or in case of a levy by execution on the lessee's right or interest in the crops, then this lease shall, at the option of the said lessor. cease and absolutely determine, and any attorney may immediately thereafter. as attorney for the said lessee, at the sole request of the said lessor, sign an agreement for entering in any competent court, an amicable action and judgment in ejectment (without any stay of exe- 
cution or appeal) against the said lessee and all persons claiming under said lessee for the recovery by the said lessor of possession of the hereby demised premises, without any liability on the part of the said attorney, for which this shall be a sufficient warrant; and thereupon a writ of habere facias fossessionem may issue forthwith without any prior writ or proceeding whatsoever, and the lessee hereby releases to the lessor all errors and defects whatsoever in entering such action or judgment, or causing such writ of habere facias possessionem to be issued, or in any proceedings thereon, or concerning the same; and hereby agrees that no writ of error or objection or exception shall be made or taken thereto; and a copy of this lease verified by affidavit, being filed in said action, it shall not be necessary to file the original as a warrant of attorney, any law or rule of court to the contrary notwithstanding. No such determination of this lease, nor taking or recovering possession of the premises, shall deprive the lessor of any other action against the lessee for possession, rent, grain, or damages. All rights and liabilities herein given to or imposed upon either of the parties hereto, shall extend to the heirs, executors, administrators, successors and assigns of such party.

In witness whereof, the said parties have hereunto set their hands and seals this day of , one thousand nine hundred.

Sealed and delivered in

the presence of

SEAL.

SEAL.

\section{Farm Lease on Shares, Short Form.}

510. This agreement, made this 2oth day of October, A. D. 1864 , between J. J. Brown, of the one part, and J. L. Jaquette, of the other part, as follows:

That for the term of one year, commencing on the first day of April, I 865 , to be fully completed on the thirty-first day of 
March, 1866, the said Jaquette for and in consideration of one-half the product, agrees to farm for the said J. J. Brown, the land lately purchased by him of John E. Morgan, on the following terms and conditions : Each party is to find one-half the stock, including cattle, poultry, etc., and one-half the seeds for crops. The said Jaquette to find all the farming implements and all the working stock, and it is distinctly understood that no more of such stock is to be kept on the place than is absolutely necessary for the working thereof. The said Jaquette to find all the requisite labor, pay the road tax and one-half of all other taxes. He is to submit to J. J. Brown at the end of every month or three months, as may be agreed upon, a true and careful statement of all receipts and make settlement of the same. No timber is to be cut on the premises without the special direction of the owner. The fences are to be kept in good repair, the weeds kept down and the premises generally preserved in tidy and neat order. J. J. Brown is to pay one-half the blacksmith's and wheelwright's bill, and reserves for himself the privilege, should he at any time desire, of keeping on the farm, for his own use, one horse.

Note.-The above form appears in the report of the case of Brown $v$. Jaquette, $94 \mathrm{~Pa}$. II3, in which it was held that there was a lease of the farm on shares, and not a partnership; that the interest of Jaquette was divested by a sheriff's sale, as well as the right of Brown to distrain.

Covenant that the Lessee shall Fallow the Land, and Mow but Once a Year, etc.

$5 \mathrm{Ir}$. And also that he, the said C. D., his executors, administrators or assigns, shall not crop or sow any part of the arable land which he hath liberty to keep in tillage as aforesaid, above two years together, but every third year permit the same to lie fallow and unsown, and not cross-crop the same or any part thereof; and when and as it shall be laid down, shall and will sow the same with grass seed in a husband-like manner, and shall not mow or cause to be mowed, 
any of the meadow or pasture ground hereby demised, more than once in any one year of the said term; but shall and will, during the said term, plough, sow, manure and manage all the ground hereby demised in a due and regular course of husbandry, according to the custom of the country, and preserve all the trees, young oaks and saplings growing on the said premises, and not to do or commit or cause to be done or committed, any manner of waste, spoil or destruction in or upon the said demised premises or any part thereof.

\section{Covenant that Iessee may Dispose of Hay and Straw.}

512. And also that he, the said C. D., his executors, administrators or assigns, shall and may, at any time during this demise, except only in the last year thereof, have liberty to dispose of any quantity of the hay and straw arising from the said premises, on bringing and laying upon the same premises, where most need requires, one good load of rotten dung for every load of hay or straw so sold and disposed of.

\section{Covenant to Lay Down Part of the Ground with Clover, etc.}

5I3. And also that he, the said C. D., his executors, administrators or assigns, shall and will, the summer preceding the expiration or other sooner determination of this demise, summer-fallow twenty-five acres of such part of the arable land hereby demised, as shall be then in course, in a husbandlike manner, fit to be sown with a crop the ensuing season, and also lay down with clover seed and rye grass, twentyfive acres more of the arable land hereby demised, which shall be then in tillage and sow upon each acre thereof ten pounds of the best clover seed and two bushels of the best rye grass . seed.

That the Lessee shall Use the Hay, Dung, etc., on the Premises.

5I4. And also that he, the said C. D., his executors, administrators or assigns, shall and will, during the continuance of this demise, use and spread on the said demised premises, all 
the hay and straw arising therefrom, and all the compost and dung which shall be made thereby shall spread and bestow upon the said premises in a husband-like manner, save only the compost or dung to be made in the last year of his demise, which the said C. D., his executors, administrators or assigns shall leave upon the said premises, unto and for the said A. B. or his assigns, if then living, but in case of his decease, to and for such other person or persons as shall then be entitled to the freehold and inheritance of the said premises without being paid or allowed anything for the same.

\section{Fire Clause for Farm Iease, No. 1.}

5 I5. It is hereby mutually agreed and provided that in case the dwelling house or barn on the demised premises, by reason of fire or other casualty, shall be totally destroyed or rendered unfit for continued occupancy, then the said lease shall continue until the maturity of the crops the lessee may have planted on said premises and until the expiration of a reasonable time for harvesting such crops and taking the same away, and the lease shall then terminate and rent shall be apportioned and paid to that time, but the lessee shall be allowed and have deducted from his rent the rental value of such portions of the demised premises as he shall be deprived of by such fire or casualty. Provided, however, that in such case the lessor shall have the right at any time after the fire or casualty to enter said premises with his employés, contractors, workmen, materials and vehicles and to rebuild the building or buildings destroyed or damaged by such fire or casualty, which shall then become the property of the lessor free from any rights of the lessee to the same, and the lessor may, at any time. rent such buildings again to the said lessee or any other party. And it is hereby agreed that in case of a partial destruction or damage of the dwelling house and barn or either of them, by fire or other casualty, so that they can both be continued to be occupied, then the lessor shall, with the least possible delay, have the said premises 
restored to the same condition as before such loss or damage by fire or other casualty; but said lessee shall be allowed and have deducted from his rent the rental value of such parts of the demised premises as he shall be deprived of until such repairs are completed.

\section{Fire Clause for Farm Lease, No. 2.}

516. It is hereby mutually agreed and provided that in case of a total destruction of the dwelling house or barn, or in case that either of them shall become untenantable or unfit for occupancy by reason of fire or other casualty, then this lease shall terminate on the date of such fire or casualty, and the rent shall be apportioned and paid to that date; but if in any such case the lessee shall have any crops planted or growing in said farm, they shall belong to the said lessee, who shall have the right to cultivate, harvest and take them away in the proper season, but for sucl continued partial use and occupation, the said lessee shall pay the lessor such a reasonable sum as may be agreed upon by the parties, but in case they cannot or will not so agree, then each party shall choose an arbitrator to fix such amount, but if the arbitrators cannot or will not agree, they shall choose a third arbitrator to act with them, and the decision shall be by a majority of the arbitrators, which decision shall be final and conclusive upon the parties.

\section{Fire Clause for a Dwelling.}

$5^{\text {I }}$. It is hereby agreed that if the dwelling on the demised premises shall be wholly destroyed or damaged by fire or other casualty or shall be partially destroyed or damaged by fire or other casualty, so that the same cannot be continuously occupied, then, and in either such case, the lease shall terminate on the date of such fire or casualty, and the rent shall be apportioned and paid to that date; but in case of a partial loss or damage so that the said dwelling can be continuously occupied whilst repairs are being made, then the lease shall 
be continued and the said lessor, with workmen and others, at seasonable times in the daytime, may enter said building and premises and shall repair and amend the said building at his own cost and expense as soon as the same can be practically done, and in case of such continued occupancy, the lessee shall be allowed and have deducted from his rent, such part thereof as shall compensate him for being deprived of any portions of the building or premises until repairs are made; such compensation, however, being rated and estimated only according to the rental value of such portions during the deprivation thereof.

\section{Fire Clause for a Business Property.}

$5^{18}$. It is hereby agreed that if the building on the demised premises shall be wholly destroyed or damaged by fire or other casualty, or in case the said building shall be partially destroyed or damaged by fire or other casualty, and such partial destruction or damage shall be so great, to such an extent or of such a nature or character, as to prevent the occupation or the continuation of business on the demised premises; or if the destruction or damage of the property of the lessor or lessee in said building by such fire or casualty, shall be so great, to such extent or of such a nature as to prevent the continuation of said business at an early date or profitably; then in either such case of total or partial destruction or damage, this lease shall terminate at the date of such fire or casualty, and the rent shall be apportioned and paid to that date; but otherwise and in case of a partial destruction or damage of said building or the contents, by fire or other casualty, so that the same can be continued to be occupied and said business can be continued profitably, then this lease shall be continued and the lessor, with his workmen and others, may enter said premises at reasonable times, during working hours, to repair said building, and the said lessor shall, with due diligence, at his own cost and expense, repair said premises and the lessee shall be allowed and have deducted from 
his rent such an amount as will compensate him for being deprived of any portions of said premises whilst repairs are being made; such compensation to be rated and estimated, however, only according to their rental value.

\section{To Protect against Assignment of Lease.}

519 . It is hereby agreed that this lease or any continuation or extension thereof, expressly or impliedly, shall not, without the written consent of the lessor, or his successor in title, be sold, assigned, transferred or mortgaged by the lessee, or his successor in title, or by reason of his or their death, bankruptcy or insolvency, or by execution, by attachment, by operation of law, or by any legal or equitable proceedings whatever in any way or manner, and upon any of such occurrences happening, this lease shall, at the option of the lessor, his heirs and assigns, terminate, and upon such termination, the rent shall be apportioned and paid to the lessor and his successors to the date of any such occurrences, and possession can be recovered by the amicable ejectment proceedings hereinafter mentioned; and it is further agreed that any consent of the lessor, his heirs or assigns, to any assignment of this lease, shall not obviate the necessity of obtaining consent to any future assignments; and the rights of the lessor, his heirs and assigns, to terminate the lease shall not be lost or waived by the receipt of rent or any other act, excepting written consent aforesaid; and this clause against assignments shall extend to and bind, not only the lessee, but all persons claiming by, through or under him, or under this lease.

\section{For Insertion after Ejectment Clause.}

520. [Clause to be inserted after an ejectment clause.] It is agreed that the lessee shall not make any defence to the proceedings or judgment in ejectment above provided or to any proceedings in relation thereto, by reason of any rent not having been demanded or collected when due, or any habit 
or custom in collecting or receiving rent after the same shall fall due, or by reason of any act or acts of the lessor by the receipt of rent or otherwise, which might be a waiver of his rights to said ejectment proceedings, or by reason of any misdescription or inadequate description of the demised premises in said proceedings; and that the above ejectment clause shall run and be binding upon and operative against any person or persons, company or corporation who may become a tenant under this lease, or any renting thereunder. or under the terms thereof, by assignment, operation or implication of law, or otherwise; and further, no objection shall be made by reason of the joinder of improper parties in the ejectment proceedings, or by reason of the lessor not having given to the lessee any notice before proceedings in ejectment, and all agreements for said ejectment proceedings shall run with the land and be for the benefit of the lessor and against the lessee and their respective successors in title.

\section{Giving an Option to Purchase.}

$52 \mathrm{I}$. It is hereby agreed that the lessee shall have the op. tion to purchase the said demised premises [here give a particular description of the premises if general description indefinite in lease] at any time during the existence of any tenancy express or implied under this lease for the price or sum of $\$$ in the following manner, viz.: $\$$ to be paid in cash upon the exccution and delivery of the deed and the balance thereof $\$ \quad$ is to be paid at the expiration of five years from the execution and delivery of the deed, with interest at the rate of five per cent. per annum, payable half yearly, and the payment of which balance shall be secured upon the said premises by a purchase-money mortgage with bond and warrant of the said lessee of the usual form, and the said lessee shall assign to the said lessor a perpetual fire insurance of said premises for the sum of $\$$

as collateral security for the payment of the said mortgage debt, and upon the said lessee giving written notice to the said les- 
sor of the exercise of his said option and offering and agreeing to purchase said premises upon the said terms, then the said lessor and his wife shall and will sell, grant and convey the said premises to the said lessee upon said terms. It being hereby agreed and provided that the lessee shall remain as lessee under said lease and letting until the execution and delivery of the deed of conveyance. The said wife of the said lessee has signed and acknowledged this lease with her husband so that the lessee in case he shall purchase shall have a title free of her interest.

\section{Surety for Tenant.}

522. I, A. B., do hereby agree to be responsible as surety to C. D. or his assigns, for the true and faithful performance of the above-named contract on the part of E. F., and this obligation shall extend to and bind the executors and administrators of the said A. B., and shall extend to and be for the benefit of C. D., his heirs, assigns and successors in title, and as long as the above lease and any letting thereunder shall continue.

In witness whereof, I have hereunto set my hand and seal, the day of one thousand nine hundred.

Sealed and delivered in the presence of

SEAL.

\section{Assignment of Lease.}

523. This indenture, made the day of , A. D. 1900 , between A. B., of , of the first part, and C. D., of , of the second part, Witnesseth that the said A. B. for and in consideration of the sum of dollars, to him in hand paid by the said C. D., at and before the ensealing and delivery of these presents, the receipt whereof is hereby acknowledged, hath granted, bargained, sold, assigned, transferred and set over and by these presents doth grant, bargain, sell, assign, transfer and set over unto the said C. D., his executors, administrators and assigns a certain lease, bearing 
date the Ist day of January, I895, made between E. F., of the one part, and the said A. B., of the other part, of the premises [here briefly describe the premises] for the term of years at and under the rent of per annum. Together with the said premises and all the rights and privileges of the said A. B. to the same and by and under said lease. To have and to hold the said premises and every part thereof with the appurtenances unto the said C. D., his executors, administrators and assigns, for and during all the rest, residue and remainder yet to come and unexpired of the said term of years, in as full, large and ample a manner to all intents and purposes as the said A. B., his executors, administrators or assigns now holds or may at any time hold, and enjoy the same by virtue of the said lease. Subject, nevertheless, to the several rents, covenants, conditions and agreements in the said lease reserved and contained.

In witness, etc.

SEAL.

\section{Surrender of Lease.}

524. Know all men by these presents that the undersigned A. B. doth hereby, on the date hereof, surrender and yield up to C. D. the lease made by the said C. D. to the said A. B., dated the day of A. D. I885, for premises [here describe the premises] and the possession of the said premises; and the said C. D., in consideration thereof doth hereby accept the said surrender and possession.

Witness the hands and seals of the said parties this day of , A. D. I900.

Witnesses :

SEAL.

SEAL.

Distress Warrant.

525. To , constable of

Whereas, C. D. is indebted to me in the sum of dollars and cents for the rent of [here briefly describe the premises] due on the day of , A. D. I899, 
you are hereby authorized and empowered to collect the sand amount of rent, by distraining the goods and chattels in and on said premises, according to the acts of assembly in such case made and provided; and to proceed to sell the same according to law, for the best price that can be obtained for the same, returning the overplus if any, to the said C. D. after paying the said rent and all legal costs and charges of such distress.

Witness my hand and seal this Ist day of January, I90o.

\section{A. B. SEAL.}

By virtue of the above landlord's warrant, I do levy on the following goods, being on the premises, to wit:

One piano.

One carpet.

January I, 1900 .

O. P., Constable.

Notice of Distraint.

526.

A. B.

$v$.

C. D.
By virtue of a landlord's warrant to me directed and dated the Ist day of January, 1900, for the sum of dollars I do hereby levy on the following goods, being on the premises therein described.

Debt, .............\$

To wit:

One piano.

One carpet.

To C. D.

Take notice, that by authority and on behalf of your landlord, A. B., I have this day distrained the several goods and chattels specified in the above schedule, on the premises situate for the sum of dollars, rent due to him, the said A. B., as aforesaid, and if you do not pay the said 
rent so due and in arrear as aforesaid, or replevy the same goods and chattels according to law, within five days hereafter, I shall, after the expiration of the said five days from the date hereof, cause the said goods and chattels to be appraised and sold according to the act of assembly in such case made and provided.

Given under my hand the Ist day of January, I90o.

O. P., Constable.

Afflavit of Appraisers and Appraisement.

527. We, G. W. and T. J., being duly say that we will well and truly, according to the best of our understanding, appraise the goods and chattels of C. D., distrained for rent by $A$. $B$.

and subscribed before me

this day of A. D. 1900.

G. W.

T. J.

Appraisement of the goods and chattels of the abovenamed C. D.:

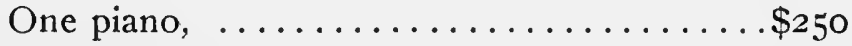

One carpet, ................ 50

day of , A. D. 1900 .

$\$ 300$

G. W.

T. J.

\section{Consent of Tenant to Permit Distrained Goods to Remain.}

528. I, C. D., do hereby consent that A. B., my landlord, shall continue in possession of my goods and chattels on $\mathrm{my}$ premises, upon which he has distrained for rent, for the space of days from the date hereof, he at my request having agreed to extend the time of sale of said goods and chattels until that time.

Dated the day of A. D. 1900 .

C. D. 
Notice of Constable's Sale.

529. Will be sold at public vendue, on the day of A. D. I900, at [briefly describe place of sale] the following goods and chattels, distrained for rent as the property of C. D., that is to say:

One piano.

One carpet.

O. P., Constable.

Claim for Beneft of Exemption Law.

530. To , constable.

Sir:-Please take notice that as to the distraint of A. B. upon my goods for rent, I claim the benefit of the act of assembly, approved the 9th day of April, A. D. 1849, entitled, "An act to exempt property to the value of three hundred dollars from levy and sale on execution and distress for rent." And that I desire appraisers summoned and an appraisement made of the goods elected to be retained by me under and according to said act.

C. D.

\section{Summons of Appraisers.}

531. To M. N., G. H., K. L.

You are hereby summoned to appraise, after having been duly sworn or affirmed, the goods of C. D., distrained upon for rent due to A. B., which he may elect to retain to the value of three hundred dollars under the exemption law.

O. P., Constable.

Affidavit of Appraisers and Election.

532. We, the subscribers, having been summoned by $O$. $\mathrm{P}$., constable, to appraise the goods of C. D., distrained upon for rent due A. B., and which the said C. D. may elect to retain, under the exemption law of 1849 , being duly sworn 
or affirmed, say that we will well and truly appraise the same.

M. N.,

G. H.,

K. L.

Sworn to or affirmed before me this day of A. D. 1900 .

To M. N.)

G. H. Appraisers.

K. L.

Sirs:-Please notice that I hereby elect to retain the following goods to be exempted under the $\$ 300$ exemption law.

Viz.: One piano.

One carpet, etc.

Appraisement of Exempted Goods.

C. D.

533. We, the subscribers, the appraisers appointed to appraise the goods of C. D., distrained upon by A. B. for rent, and claimed by the said C. D. as exempt under the $\$ 300$ exemption law, and having been respectively sworn or affirmed, do value and appraise the same as follows:

One piano, ................\$250.

One carpet, .................. 50

$\$ 300$

Appraised the day of I9.

Amicable Action and Judgment in Ejectment.

M. N.

G. $\mathrm{H}$.

K. L.

534.

$\left.\begin{array}{c}\text { A. B., plaintiff, } \\ v \text {. } \\ \text { C. D., defendant. }\end{array}\right\} \begin{gathered}\text { In the Court of Common Pleas of } \\ \text { county, Pa. }\end{gathered}$

Amicable Action and Confession of Judgment in Ejectment by a provision in a lease. 
Whereas, the above-named A. B., by a certain lease dated the first day of January, I900, leased and demised to the said C. D. [here describe premises as in the lease], said lease is hereunto annexed and made a part of this document. And whereas, the said C. D. entered into possession of said premises under the said lease as tenant thereunder and is still in possession of the same. It is hereby agreed that an amicable action in ejectment be entered by the prothonotary of the court of common pleas of county, as if a summons in ejectment had been issued by A. B., the said plaintiff, against C. D., the said defendant, for [here describe the property as in the lease, and if not described according to a street number in a city or town, or by metes and bounds, describe the premises more particularly; for example say: and which premises are more particularly described as follows, viz.: All that certain three-story brick dwelling house and lot of ground on which the same is erected, situate on the south side of Washington street, fifteen feet westward from the west side of Front street, in the city of Philadelphia, containing in front on Washington street fifteen feet and extending of that width southward between parallel lines at right angles with said Front street sixty feet; or as follows, viz. : All that certain tract of land and farm with the buildings and improvements thereon erected, situate on the west side of road, between road and road, in township, in the county of , in the state of Pennsylvania, containing acres, and bounded on the east by said road, on the north by land of , on the west by land of , and on the south by land of ] and as if said summons in ejectment had been issued and made returnable to the Monday of , I900, and had been duly returned "served" by the sheriff upon the said C. D. And the said C. D. hereby confesses judgment in ejectment for said premises in favor of said A. B., plaintiff, without any stay of execution, appeal, writ of error or objection or exception. This judgment is entered under, by virtue of and in purstance of an agreement and provision in the 
said lease and upon the determination of the lease by reason of the said C. D. not having paid to A. B. the following rent under said lease, due as follows, viz.: one month's rent, due day of , A. D. $1900, \$ 25$, but in permitting the same to be in arrears and unpaid, whereby the said lease has absolutely ceased and determined, G. H., as attorney for C. $D$., has signed this agreement under and by virtue of the authority in said lease.

E. F., attorney for A. B., the plaintiff.

G. H., attorney for C. D., the defendant.

County of Philadelphia, ss.

A. B., being duly sworn, doth depose and say, that the facts set forth in the above agreement are true; that the lease referred to in the agreement is annexed thereto; that the abovenamed C. D. has not paid to this deponent $\$ 25$, one month's rent due under said lease and which became due on the day of A. D. 1900, and that said rent is, remains and now is wholly unpaid and the said C. D. is indebted to this deponent for the same.

Sworn and subscribed, etc.

A. B.

Notice to Quit for Non-Payment of Rent under Act of 1830.

Philadelphia, , I9 . To

You are hereby notified to quit the premises situate which I have leased to you, reserving rent-"or pay and satisfy the rent due and in arrear," being $\$$, which amount was due on the day of , 19, and is hereby demanded-(you having neglected or refused to pay the amount so reserved, as often as the same has grown due, according to the terms of our contract-and there being no goods on the premises adequate to pay the rent so reserved, except such articles as are exempt from levy and sale by the laws of this commonwealth) within fifteen days [or thirty days, accord- 
ing to the time of year] from the date hereof, or I shall proceed against you as the law directs.

Respectfully yours,

Complaint.

536. County of

ss.

On this day of

peared before me, one of the

, A. D. I9, personally apin said county,

who, being duly sworn according to law, saith: That he demised the premises situate to a certain for the term of reserving rent; that the said rent is in arrear and unpaid; that there are not sufficient goods and chattels on the premises to pay and satisfy the said rent, except such as are by law exempt from levy and sale, and that the said lessee has (after being notified to quit the said premises within days from the date of said notice) refused to render and deliver up possession of the said premises.

SEAL.

Sworn and subscribed before me,

I9.

\section{Summons.}

537. City of Philadelphia, ss.

The Commonwealth of Pennsylvania, to any constable of said city, greeting:

Whereas, Complaint on oath or affirmation hath been made before me, the Subscriber, Magistrate of Court No.

$$
\text { , of said city by that demised to }
$$

the premises situate No. street, in said city, reserving rent, which rent is in arrear and unpaid, and there are not sufficient goods and chattels on the premises to pay and satisfy the said rent, except such as are by law exempted from levy and sale; and that the said lessee has, after being notified according to law, refused to pay the rent in arrear or remove and re-deliver up possession of the premises:

You are therefore hereby commanded to summon the said 
to be and appear before the said magistrate, at his court, on the day of , A. D. 19 , between the hours of o'clock M., and o'clock M., to answer the said complaint.

Witness our said magistrate and the official seal of the said court, the day of , A. D. 19 .

Magistrate of Court No.

\section{Writ of Restitution.}

538. County of ss.

The Commonwealth of Pennsylvania, to any constable of the said county, greeting:

Whereas, proof was made on the day of I9 , before , one of in said county, That rented to a certain tenement, situated in the rent whereof is in arrear and unpaid; that there are not sufficient goods and chattels on the premises to pay and satisfy the said rent, except such as are by law exempt from levy and sale, and that the said lessee has, after being legally notified, refused to remove and re-deliver up possession of the premises, according to the act of assembly in such case made and provided, and whereon the said in consideration of the premises, did enter judgment against said lessee that said premises should be delivered up to the lessor, and did also ascertain the amount of rent in arrear to be dollars.

Therefore we command you forthwith to deliver actual possession of said premises to the lessor, and we also command you that you levy the costs indorsed hereon on the goods and chattels of the said and of your proceedings herein make return to the said within ten days after your receipt of this writ, to wit: on the day of

I9.

In witness whereof, the said hand and seal the day of

hath hereunto set his

SEAL. 
FORMS.

Record.

539.
A. B.
Landlord and tenant case.
C. D.
Costs.
On the day of
A. D.
A. B., the plaintiff, appears and com- plains, on oath, that on the day of A. D. he demised to C. D., the defendant (here describe prem- ises), for the term of
at the rent

of per annum, payable quarterly; that on the day of A. $D$. the amount of dollars of said rent due, according to the terms of said demise, on the day of A. $D$. , was in arrear and unpaid; that on the day of

A. D. , he notified the said defendant, C. D., that such amount of rent was due, and demanded payment thereof, or in default that the said defendant should quit the said premises within days from the service of said notice; that there are not on the said premises sufficient goods, etc., exempted from levy and sale; and that the said defendant, after being so notified, has refused to deliver possession of said premises to said A. B. Same day, summons issued returnable . E. F., constable. Returned on oath, "Served by delivering a true copy to the said defendant personally upon the premises on the

$\therefore$ The day of , A. D. day of

A. D.

, parties appear. G. H. sworn for plaintiff. Whereupon, on hearing, it appearing that the above complaint is in all particulars just and true, judgment is entered against the said defendant, that he deliver actual possession of the premises to the plaintiff; and it is ascertained that the rent due to the plaintiff is

The day of

sued. Returnable the

Possession given the
A. D. day of day of writ of possession isof $A . D$.

, A. D. 


\section{Notices to Quit at End of Lease.}

540. To A. B.: You are hereby notified and required to quit and deliver up to me possession of the premises (describing them), which you hold as tenant under me, upon the expiration of your lease, viz.: the day of A. D. , as I desire to have again and repossess the same.

C. D.

NorE.-It is suggested that the above notice can be given under either the act of 1772 or 1863 when there is a certain term and when the notice shall be given three months before the end of the term.

To A. B.: You are hereby notified and required to quit and deliver up to me possession of the premises (describing them), which you hold as tenant under me from year to year, at the end of your current term, viz.: the day of

A. D. , as I desire to have and repossess the same and to terminate the tenancy at that time.

C. D.

NotE.-It is suggested that the above notice can be given under either of said acts when served three months before the expiration of the current year if there is a yearly tenancy.

To A. B.: You are hereby notified and required to quit and deliver up to me possession of the premises (describe them), which you hold under me as tenant from month to month, at the end of the monthly term which will expire on the day of A. D. , as I desire to have again and repossess the same and to terminate the monthly tenancy at that time.

C. D.

NotE.-It is suggested that the above notice can be given under a monthly tenancy. Under the act of 1863 three months' notice must be given before the end of the lease, and where there is a monthly tenancy the notice to quit must necessarily be given three months before the termination of a future monthly tenancy. This course must be pursued or the remedy under the act of $I 772$ will have to be taken. Under that law there can be a month's notice to terminate the renting from month to month, with a notice that possession will be required three months after the notice or three months after the termination of the monthly tenancy, 
or there can be a month's notice to terminate the lease, and after it terminates three months' notice can be given for possession.

To A. B.: Sir-E. F., having leased to you the premises [here describe the premises], for the term of five years, and the said E. F. having, by deed dated the day of , A. D. , granted, assigned and conveyed the said prenises to me with the lease, you are hereby notified and required to quit and deliver up to me possession of said premises, which you now hold as tenant under me, at the expiration of the said lease, viz.: the day of , A. D. as I desire to have such possession.

C. D.

To A. B.: Sir-E. F. died on the day of , A. D. , having by his will devised to me absolutely and in fee simple the premises now occupied by you [here describe the premises], and at the time of the death of said testator you held said premises as his tenant from year to year, which rental has continued since then. Therefore, you are hereby notified and required to give me possession of said premises, which you hold as tenant under me from year to year, at the end of your current term, viz.: the day of , A. D. , as I desire to terminate the lease at that time and to have possession of said premises.

C. D.

\section{Complaint for Possession under Act of 1772.}

54I. To David Beitler and Robert R. Smith, two of the aldermen in and for the city of Philadelphia: The complaint of Nelson Gavit, by A. F. Blair, agent, most respectfully sets forth: That he is the owner of a certain tenement, with the appurtenances, situate No. I4I9 Race street, in the city of Philadelphia, and was in possession thereof on August I, I871, when he demised the said premises to a certain Mary Hall for the full term of one year from August I, I87 I, at the rent of $\$ 41.67$ per month, which said term is fully ended; That said Nelson Gavit, being desirous, upon the determina- 
tion of the said term, to have again and repossess his said estate and premises; for that purpose he did, on the I6th day of April, I872, last past, demand and require the said Mary Hall to remove from and leave the same; and that the said Mary Hall hath hitherto refused and still doth refuse to comply therewith; that three months having elapsed since the service of the said notice, and said demise ended, he makes this complaint, that such proceedings may be taken by you as are directed by the act of assembly of 1772 , in such case made and provided.

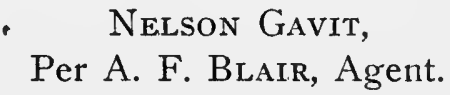

Sworn before us, this 6 th day of August, A. D. I872.

David Beitler, Alderman.

RoBERT R.Smith, Alderman.

\section{Precept to the Sheriff.}

542. County of

ss.

The Commonwealth of Pennsylvania, to the sheriff of county, greeting:

Whereas, complaint and due proof was this day made before A. B., Esq., and C. D., Esq., justices of the peace, in and for the county of , that , of , on the day of , I899, was quietly and peaceably possessed of [here describe the premises so as to certainly locate the same], in the city of Philadelphia, and being so thereof possessed, on the same day and year aforesaid, did demise the said premises to for the term of [number of years] then next ensuing, at the annual rent of dollars, and that the said by virtue of the said demise entered into possession of the said demised premises, and held the same during the said term, and is still possessed of the same, and that the said term for which the said premises were demised is fully ended; and the said being desirous upon the said 
determination of the said term to have again and repossess the said premises, for that purpose did, on the day of , I899, demand of and require the said to remove from and leave the same, on or before [date], and that the said hath hitherto refused and still doth refuse to comply with the said demand and requisition to remove from and leave the said premises: Therefore we command you, that you summon twelve substantial freeholders of your bailiwick, so that they be and appear before our said justices at in the city of Philadelphia, on the day of , A. D. I900, at P. M., and that you also summon the said so that he be and appear before our said justices and the said freeholders, at the day, time and place aforesaid, to show cause, if any he has, why restitution of the possession of the said demised premises should not be forthwith made to the said, according to the form and effect of the act of general assembly of $\mathrm{I} 772$, in such case made and provided.

Witness the hands and seals of the said Esq., at the city aforesaid, the A. D. 1899 .

$$
\begin{aligned}
& \text {, Esq., and } \\
& \text { day of }
\end{aligned}
$$

SEAL.

SEAL.

Inquisition.

543. Inquisition taken at , A. D. I900, before in the county of , Esq., and , Esq., two of our justices of the peace, by the oaths of and the solemn affirmations of , twelve substantial freeholders of the said county; who, upon their oaths and affirmations with the said justices respectively, do say and find that A. B., on the day of , A. D. I900, was quietly and peaceably possessed of certain premises [particularly describe the same], and being so possessed thereof, on the same day and year last aforesaid, did demise the said premises to $C$. D. for the term of years then next ensuing, at the rent of dollars per annum, and that said C. D., by virtue of the 
said demise, entered into possession of the said demised premises, and held the same during the said term, and is still possessed of the same; and that the said term for which the said premises were demised is fully ended; and the said A. B., being desirous upon the said determination of the said term to have again and repossess the said premises, for that purpose did, on the day of , r9oo, demand of and require the said $C$. $D$. to remove from and leave the same within , and that the said C. D. hath hitherto refused and still doth refuse to comply with the said demand and requisition to remove from and leave the said premises, and the said freeholders do assess damages against the said C. D. for the unjust detention of the said demised premises at $\$$, beside all costs of suit.

Whereupon it is considered and adjudged by the said E. F. and G. H., justices aforesaid, and they enter judgment, that restitution of the said demised premises be made to the said A. B., and that he recover of the said C. D. his damages aforesaid, together with costs of suit amounting to $\$$

In testimony whereof, as well the said justices as the said freeholders have, hereunto set their hands and seals the day and year first above written at aforesaid.

Justice of the Peace.

SEAL.

Justice of the Peace.

SEAL.

(Signatures of freeholders opposite their seals.)

Record.

544. Be it remembered, That on the day of A. D. I900, at in the due proof was made before A. B., Esq., and C. D., Esq., two of our justices of the peace. that E. F., of , on the day of , A. D. 
was quietly and peaceably possessed of premises [here particularly describe them], and being so thereof possessed, on the same day and year last aforesaid, did demise the said premises to G. H., of the said next ensuing, at the rent of , for the term of then the said G. H., by virtue of the said demise, entered into possession of the said demised premises and held the same during the said term, and is still possessed of the same, and that the said term for which the said premises were demised is fully ended; and the said E. F., being desirous upon the determination of the said term to have again and repossess the said premises, for that purpose did, on the A. D. , demand of and require the said from and leave the same, on or before, and that the
said $G$. $H$. hath hitherto refused and still doth refuse to comday of

to remove ply with the said demand and requisition to remove from and leave the said premises. Whereupon the said E. F. then, to wit, on the said day of , A. D. , at the aforesaid, prayed us, the said justices of the peace, that a due remedy in that behalf be provided for him according to the act of the general assembly of the state of Pennsylvania in such case made and provided; upon which proof and complaint the sheriff of the county of is commanded that he summon twelve substantial freeholders of his bailiwick, so that he be and appear before us, the said justices, at the [place of meeting] on the day of , A. D.

at o'clock, P. M., and that he also summon the said , so that he be and appear before us, the said justices and the said freeholders, at the day and place last aforesaid, to show cause, if any he has, why restitution of the possession of the said demised premises should not be forthwith made to the aforesaid . Afterwards, to wit, on the said day of , A. D.

Esq., sheriff of the county of , at the [place], said justices, and returns that by virtue of the said warrant to him directed he had summoned twelve substantial free- 
holders, to wit [give the names of the freeholders], and had also summoned the said to be and appear on this day and place, as by the said warrant he was summoned; and the said freeholders, being called, appear, and are severally sworn and affirmed. And the said also appears; that we, the said justices and the aforesaid freeholders, proceed to hear and examine the proofs and allegations offered by the said parties [note witnesses examined], and do find that the said on the day of , A. D. , was quietly and peaceably possessed of premises [here describe the premises]. And being so thereof possessed, on the same day and year last aforesaid did demise the said premises to the said for the term of years then next ensuing, at the rent of per annum, and that the said , by virtue of the said demise, entered into possession of the said demised premises and held the same during the said term, and is still possessed of the same, and that the said term for which the said premises were demised is fully ended; and that the said

being desirous upon the determination of the said term to have again and repossess the said premises, for that purpose did, on the day of , A. D. , demand of and require the said

to remove from and leave the same on or before , and the said hath hitherto refused and still doth refuse to comply with the said demand and requisition to remove from and leave the said premises. And the said freeholders assess the sum of dollars for the damages of the said, occasioned by the unjust detention of the said premises. Therefore it is considered and adjudged by us, the said justices of the peace, that the said shall and do recover possession of the said premises, and have of the said as well the said sum of dollars, for his damages aforesaid, as dollars, for his reasonable costs by him expended in and about this suit in this behalf, concerning which the premises aforesaid we do hereby make this our record.

In testimony whereof we, the said justices of the peace, 
to this our record have set our hands and seals, at aforesaid, this day of A. D.

SEAL.

SEAL.

Summons to Third Party Claiming Title.

545. County of ss.

The Commonwealth of Pennsylvania, to the sheriff of the said county, greeting:

Whereas, complaint and due proof have been made before E. F. and G. H., two of our justices of the peace [or aldermen] in and for the said county [or the city of ], that A. B., on the day of , in the year of our Lord one thousand nine hundred and, was quietly and peaceably possessed of a certain [here describe the premises as before] together with the appurtenances, and being so thereof possessed on the same day and year aforesaid, at the county aforesaid, did demise the said premises to one C. D. for the term of years then next ensuing, at the yearly rent of dollars, lawful money, payable for the same; and that the said C. D. by virtue of the said demise entered into possession of the said demised premises with the appurtenances, and held them during the said term, and is still possessed thereof, and that the said term for which the said premises were demised is fully ended and that the said A. B., being desirous upon the determination of the said lease to have again and repossess his said estate so demised, for that pirpose did, on the day of last past, require the said C. D. to remove from and leave the same, and that the said C. D. hath hitherto refused and still doth refuse to comply therewith. And whereas, the said C. D. being duly summoned doth appear before our said justices [or aldermen] and doth allege that the title to the said [messuage or otherwise, as the case may be] is disputed and claimed by O. P., of , in the said county, in virtue of a right or title accrued or happening since the commencement of the lease so 
as aforesaid made to him the said C. D. by virtue of a deed made by the said $A$. B. to the said O. P., you are therefore commanded to summon the said O. P. to appear before our justices [or aldermen] at the on the day of instant at o'clock in the noon, to declare on oath or affirmation to be by our said justices [or aldermen] administered that he verily believes that he is entitled to the premises in dispute; and with one or more sufficient sureties to become bound by recognizance in the sum of to the said A. B., his heirs or assigns, to prosecute his claim at the next court of common pleas to be held for the said county (if to him it shall be expedient). Make return hereof according to law.

Witness the said E. F. and G. H., at , in the county aforesaid, the day of , in the year of our Lord One thousand nine hundred and
E. F.
G. $\mathrm{H}$.

Complaint for Possession under Act of 1863.

546. County of

On this

ss. day of
A. D. 189 , personally appeared before me, the subscriber, one of the in said county who, being duly according to law, doth depose and say: That on the day of r 189 , he was quietly in possession of a certain messuage or tenement, with the appurtenances, situate ; that on the said lastmentioned day he demised said premises to a certain for the term of at the rent of dollars which said term is fully ended; that the said being desirous upon the expiration of the said term to have again and repossess the said premises, for that purpose did, three months previous to such expiration, demand and require of the said and that the said to remove from and leave the same, fusing to comply therewith, he makes this complaint that 
such proceedings may be taken as are directed by the act of assembly in such case made and provided.

and subscribed before me,

I89.

SEAL.

Summons.

547. County of

ss.

The Commonwealth of Pennsylvania, to any constable of the said county, greeting:

WhereAs, it appears to me, the subscriber, one of the in said county, by complaint on oath that was on the day of 189 , quietly in the possession of a certain messuage or tenement, with the appurtenances, situate that on the said last-mentioned day demised said premises to a certain for the full term of at at the rent of which said term is fully ended; that the said being desirous upon the expiration of the said term to have again and repossess the said premises, for that purpose did, three months previous to such expiration, demand and require of the said the same, and that the said to remove from and leave still doth refuse to comply therewith.

You are therefore hereby commanded to summon the said to be and appear on the day of 189 , between the hours of and o'clock, M., at the office of the subscriber, to show cause, if any has, why restitution of the possession of the said premises should not be forthwith made to the aforesaid according to the form and effect of the act of assembly in such case made and provided. And this you shall in nowise omit.

In witness whereof, the said has hereunto set his hand and seal the day of , I89.

SEAL.

Record.

548. Be IT ReMEMBeRED, that on the day of A. D. , at the city of Philadelphia, due proof was made before A. D., magistrate of court No. , in and for the said city, 
that C. D. on the

day of

, A. D.

, was quietly and peaceably possessed of [here briefly but certainly describe the demised premises] and being so thereof possessed on the same day and year last aforesaid, did demise the said premises to E. F. for the term of years then next ensuing, at the yearly rent of dollars; and that the said E. F. by virtue of the said demise, entered into possession of the said demised premises, and held the same during said term, and is still possessed of the same; and that the said term for which the said premises were demised is fully ended; and that the said C. D. being desirous, upon the said determination of the said term, to have again and repossess the said premises, for that purpose did on the day of

A. D. , demand of and require the said from and leave the same, and that the said to remove has hitherto refused, and still doth refuse to comply with the said demand and requisition to remove from and leave the said premises. Whereupon the said then, to wit, on the said day of , A. D. , prayed the said magistrates that a due remedy in that behalf be provided for him, according to the form of the act of the general assembly of the state of Pennsylvania in such case made and provided, upon which proof and complaint one of the constables of the said city was commanded to summon the said

to be and appear on the day of , A. D. , between the hours of and o'clock in the forenoon, before our said magistrate, at his court in the said city, to show cause, if any he has, why restitution of the possession of the said demised premises should not be forthwith made to the aforesaid on the day of , A. D. and G. H., constable, returned on oath served on defendant [here insert the return of the manner of service]. Afterwards, to wit, on the said day of , A. D. , at o'clock [A. M. or P. M.], at the said court, at in the said city [here state the appearances and briefly state the evidence and note witnesses examined]. After hearing the proofs and allegations of- 
fered by the said

our said magistrate finds that the said on the day of A. D. was quietly and peaceably possessed of [here describe the premises so as to locate them] and being so thereof possessed on the same day and year last aforesaid did demise the said premises to the said for the term of years then next ensuing at the yearly rent of dollars; and that the said

by virtue of the said demise, entered into possession of the said demised premises and held the same during the said term, and is still possessed of the same, and that the said term for which the said premises were demised is fully ended and that the said being desirous, upon the said determination of the said term, to have again and repossess the said premises for that purpose did on the day of

A. D.

demand and require the said the same, and that the said

to remove from and leave has hitherto refused and still does refuse to comply with the said demand and requisition to remove from and leave the said premises. And our said magistrate doth assess the sum of dollars for the damage of the said occasioned by the unjust detention of the said premises. Our said magistrate did thereupon enter judgment against the said tenant that he forthwith give up possession of the said premises to the said lessor, and that the said lessor shall and do recover, and have of the said lessee or tenant as well the said sum of dollars for his damages aforesaid, as dollars for his reasonable costs by him expended in and about this suit in this behalf, concerning which the premises aforesaid our said magistrate doth make this his record.

In testimony whereof, our said magistrate to this, his record hath hereunto set his hand and the official seal of the said court, at the city of Philadelphia, this day of A. D.

A. B., Magistrate of Court No. . 


\section{Writ of Restitution.}

549. City of Philadelphia, ss.

The Commonwealth of Pennsylvania, to any constable of the said city, greeting:

Whereas, due proof hath been made before me, the subscriber, one of the magistrates in and for the city of Philadelphia, that A. B. did on the day of A. D. , demise to C. D. [here describe the premises] in said city for the full term of at a yearly rent of which said term is fully ended; that the said A. B., being desirous upon the expiration of the said term to have again and repossess the said premises, for that purpose did, three months previous to such expiration, demand and require of the said C. D. to remove from and leave the same; and that the said C. D. hath hitherto refused and still doth refuse to comply therewith; all which premises being duly found by me, the said magistrate, according to the form of the act of assembly in such case made and provided. You are, therefore, hereby commanded forthwith to deliver to the said A. B., full possession of the demised premises aforesaid. And you are also commanded that of the goods and chattels of the said C. D. in your bailiwick. you cause to be levied as well the sum of dollars, which the said A. B. has had awarded for damages sustained by the unjust detention of the premises, as dollars for his costs and charges by him in and about his suit in that behalf expended, whereof the said C. D. is convict. And hereof fail not.

Witness our said magistrate, at the city of Philadelplia, aforesaid, the day of , A. D.

E. F., Magistrate.

SEAL.

Notice in Case of Lost Lease.

550. Having lost the

Philadelphia, , 18 . evidence of the beginning and conclusion of your term in the following described premises 
[demised to you by ], to wit: All . And being desirous to recover possession of the said described premises, you are hereby notified that unable to make proof of the beginning and conclusion of your said term, and therefore require you, within thirty days from the time of the service of this notice to furnish in writing, with the date at which your said term of tenancy commenced, according to the terms and provisions of the act of assembly in such case made and provided.

Yours, etc.,

To

Second Notice.

$55 \mathrm{I}$.

City of Philadelphia, I8.

On the day of I8, I gave you notice that the evidence of the beginning and conclusion of the term for which the premises now occupied by you, situate

Philadelphia, was lost, etc., and that you should, within thirty days thereafter, furnish me in writing, with the date at which your term of tenancy commenced; you having failed to comply with the requirements of said notice I hereby require you to remove from said premises and deliver up possession of the same to me, within three months from the time you shall receive this notice.

Yours, etc.,

To Mr.

Notice when Tenant is Unable to Answer First Notice.

552.

City of Philadelphia, 18 .

On the day of , I8, I gave you notice requiring you to furnish me in writing, within thirty days from the time of the service of the said notice, with the date at which your term of tenancy commenced, of the premises now occupied by you, situate Philadelphia, and you having made affidavit within the said thirty days, that you are unable to comply with the requirements therein; you are hereby re- 
quired to remove from and surrender to me possession of said premises, within six months from the time you shall receive this notice.

To Mr.

$$
\text { Yours, etc., }
$$




\section{TABLE OF CASES.}

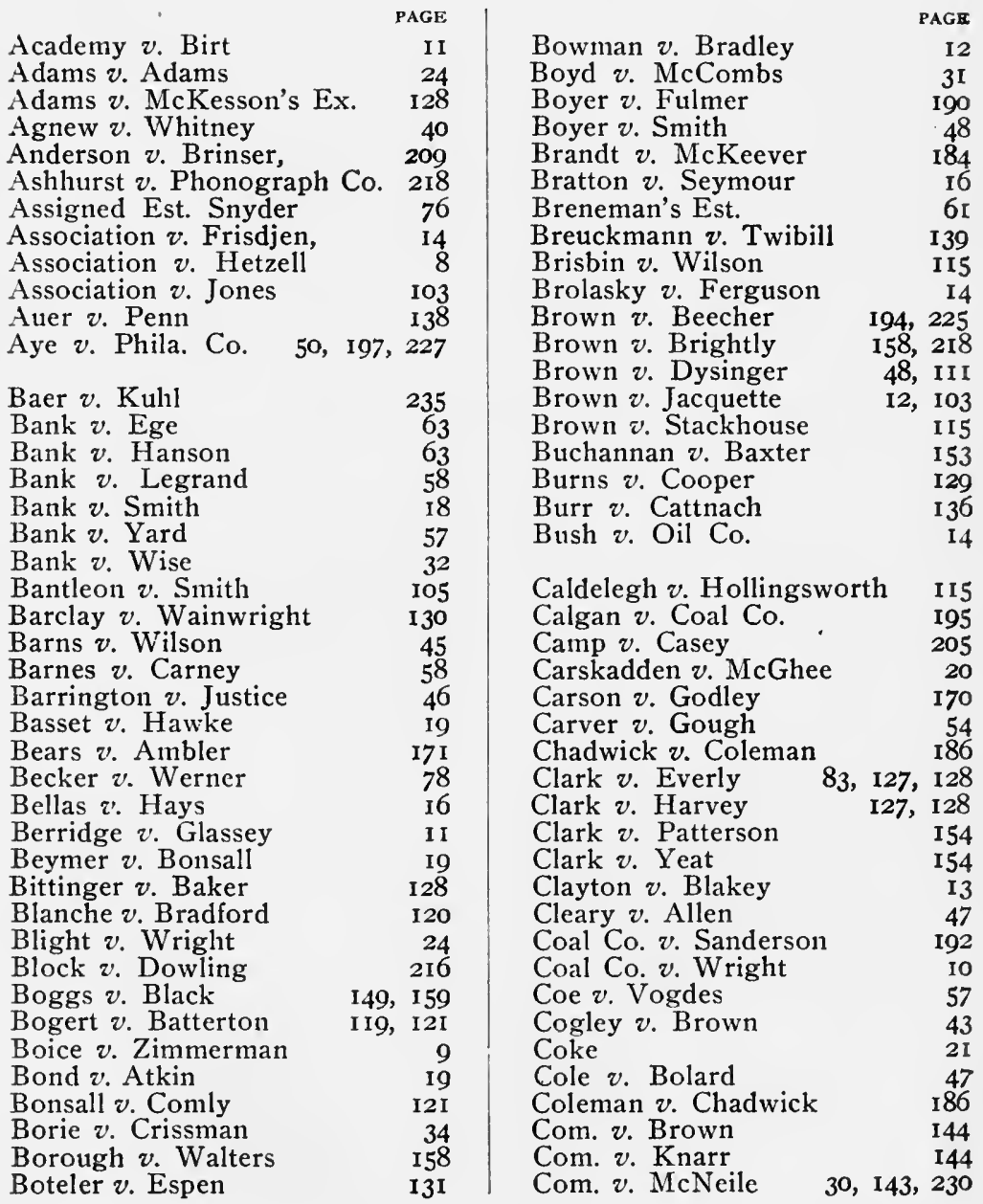


TABLE OF CASES.

Cook $v$. Neilson

PAGE

Com. v. Nichols

Com. v. Rees

109

I 42

Collins $v$. Whilldin

46

Com. v. Wisner

Cooper v. Smith

Coppel's Est.

Cornell $v$. Green

Craig v. Dale

Cunningham $v$. Eentrekin

Currier $v$. Grebe

205

Curtin $v$. Somerset

160

Curtis $v$. Hubbard

Davis $v$. Davis $4 \mathrm{I}, \mathrm{I} 17, \mathrm{I} 48, \mathrm{I} 65$

Davis $v$. Moss 54

De Coursey $v$. Trust Co. I48, I53

Delph $v$. Hoffman

Demi $v$. Bossler

De Morat $\boldsymbol{v}$. Falkenhagen

I39

Detwiler's Ap.

25, 6I

Detwiler $v$. Cox

Dickson $v$. Wolf

103

Diehl $v$. Holben

Dieffenderfer $\%$. Fisher

Dikeman v. Parrish

Diller $\%$. Roberts

Doe $v$. Bell

Donaldson $v$. Likens

Dorian $v$. Chase I35

Double $v$. Heat Co.

Duff $v$. Fitzwater I47, I48, I52

Duffee $v$. Mansfield 15,59

Duffield $v$. Rosenzweig I89

Diffy $v$. Ogden

Dumn $v$. Rothermel

Dumpor's Case

Duncan $v$. Hartman

Dunham $v$. Loverock

I7, 19,225

36
225

Dunmire $v$. Price

Dyer $v$. Wightman

Effinger $v$. Lewis

28, I9I

Ehret $v$. R. R. Co.

Elliott's Ap.

Esterly Machine Co. $v$. Spencer

Evans $v$. Hanwick

Ewing $v$. Cottman

Fahnestock $v$. Faustenauer

I 49

Farley $v$. Stokes

Fennel $v$. Guffey

Ferguson $v$. Rafferty

Finnegan $v$. Stineman

Fisher $v$. Allen

Fisher $v$. Guffey

Fitzmaurice $v$. Fabian

Flanigan $v$. Rossiter

Flanigan $v$. City

Folsom $v$. Cook

Forsythe $\because$. Price

Frank $v$. Maguire

Fretag $v$. Anderson

Fry $\because$. Jones

Furbush $v$. Chappell

Galbraith $v$. Black

Galey $v$. Hellerman

Galloway $\approx$. Ogle

Garrett $v$. Dewart

Gas Co. $v$. Johnson

Gas Co. v. Patterson

Gas Co. v. Phila. Co.

Gaskins $v$. Gaskins

Gault $v$. Neal

Gebler v. Culin

Geisenberger $v$. Cerf

Gerson, In re

Getz v. R. R. Co.

Gill v. Weston

Gillion 2 . Finley

Gillian $v$. Tobias

Gilpin $v$. Howell

Givens $\%$. Miller

Glenn $v$. Thompson

Godley $v$. Hagerty

Goehring's Ap.

Goldbeck $v$. Bank

Goodwin $v$. Sharkey

Goss $v$. Brick Co.

Grace $v$. Shively

Graham $v$. Moore

Grant's Ap.

Graver $v$. Fehr

Griffin $v$. Fellows

Griffin v. Pottery Co.

Griffiths $\%$. Marsh

Grider $v$. McIntyre

Groves $v$. Hodges

Grubb ข. Grubb

Guffey $v$. Clever

Hall $v$. Parker

Hall v. Stewart

Hamilton $v$. Ins. Co.

Hand $v$. Suravitz

Harding $v$. Seeley

Harlan $v$. Coal Co.

Harris $v$. Knowles

Hart $v$. Withers

Hartman v. Quay

Harvey v. Guntzberg

Haynes $v$. Synnott

Hazlett $v$. Powell
PAGE

104, I08

I 54

I9I

$83,147,160$ 170

74, I23, 234

97,234

I 48

I 86

32

160

91

17

I 84

201

I3I

205

2 I

228

218

I 86

20 


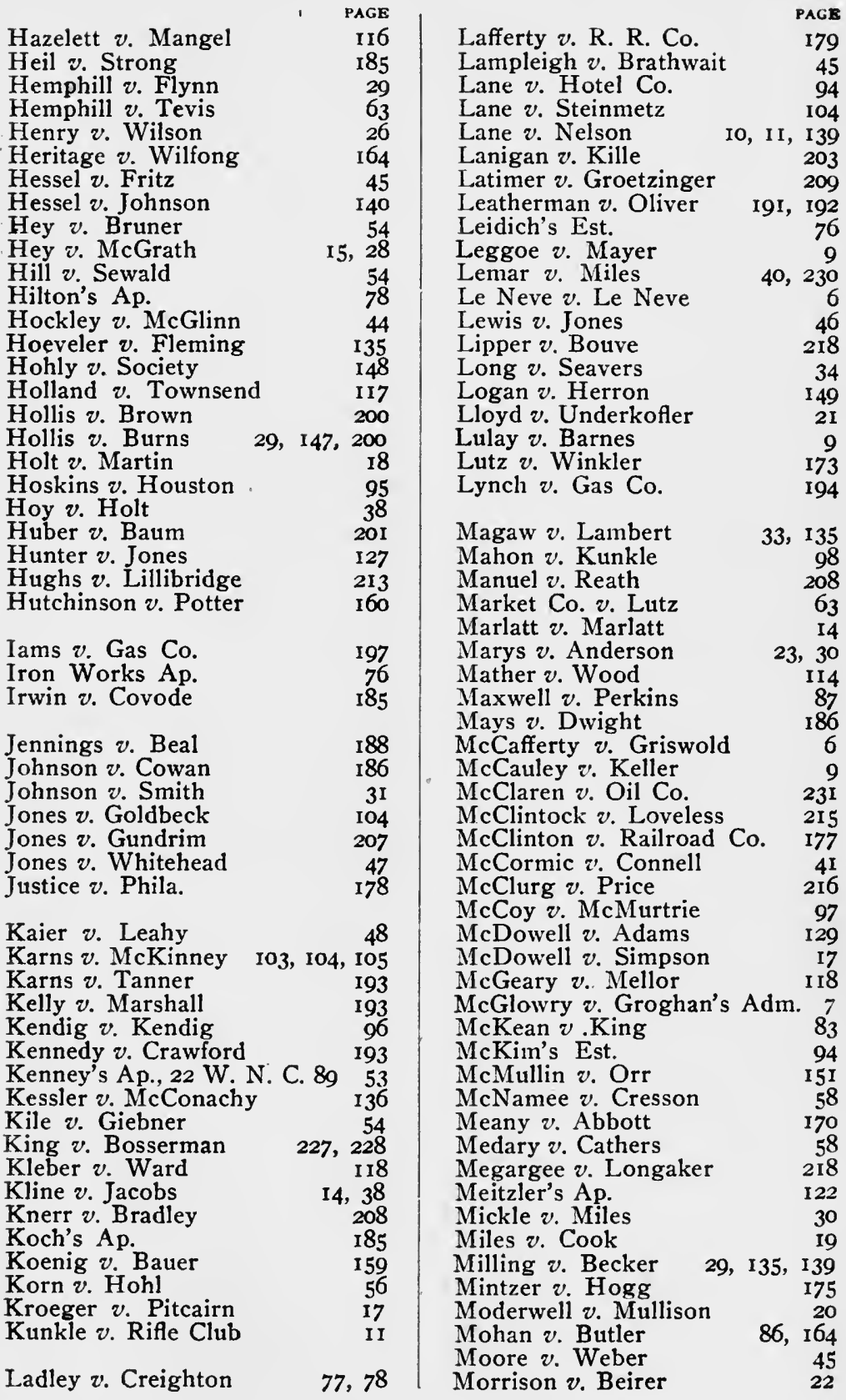


Mowne $v$. Armstrong

Mund $v$. Vanfleet

Murphy $v$. Losch

Murphy $v$. Marshall

Murray $v$. Vaughn

Myers v. Coal Co.

Myers $v$. Hulseman

Myers v. Esery

Neill $v$. Shamberg

Newell's Est.

Newell's Ap.

Newell $v$. Gibbs

Newman $v$. Rutter

Norris $v$. Gould

Oakford $v$. Nixon

Obermyer $v$. Nichols

Oil Co. $v$. Fretts

Oil Co. $v$. Railroad

Oil Co. v. Mining Co.

Oliver $v$. Brophy

Page $v$. Middleton

Palethrop $v$. Bergner

Palethorp $v$. Schmidt

Patterson $v$. Silliman

Paul $v$. Johnson

Pennant's Case

Petroleum Co. v. Oil Co.

Pfund $v$. Herlinger

Phillips $v$. Meily

Phillips $v$. Monges

Pier v. Carr

Platt $v$. Johnson

Pleasanton's Ap.

Pollard $v$. Shaaffer

Powell $v$. Campbell

Pratt $v$. Levan

Prescott $v$. Otterstatter

Prutzman $v$. Ferree

Quinn v. McCarty

Quigley v. De Haas

Railroad Co. v. Railroad Co. I77

Railroad Co. $v$. Smith

Rap v. Klair

Ray v. Gas Co.

Reaney $v$. Fannessy

Reed $v$. Kenney

Reed $v$. Ward

Rees v. Emerick

Reeves $v$. McCormick

Reid $v$. Christy

Reiff $v$. Reiff

Reigart $v$. White

Reinman $v$. Blair
PAGE

I87

9I

139

212

106

I9I

58

104, 120

I 88

208

40

48

47

201

$3 I$

I92

22

I03, 104

230

86

187

16

42

$23 \mathrm{I}$

I36

8

13

135, 136

2 I I

57

38

9 I

75

33

48

I64

17

31

I79

42, 192

139

I 30

33

106

200

$83, \mathrm{I} 5 \mathrm{I}, \mathrm{I} 6 \mathrm{I}$

126

56

40
Rich $v$. Keyser

PAGE

158

Richards v. McGrath 106,

III, II6, II 8

Riddlesburg C. \& I. Co. Ap. 98

Rinehart $v$. Olwine 34

Robb v. Carneige $\quad 192$

Roberts $v$. Ristine 4 I

Rohbock McGargo 218

Rohrer $v$. Cunningham II8

Rosenberger $v$. Hallowell 12r, 214

Sachs $v$. Schimmel

Sanders $v$. Sharp

Sausser $v$. Steinmetz

Scott $v$. Fuller

Seabrook $v$. Moyer

202

Seeger $v$. Pettit

Semayne's Case

Sennett $v$. Bucher

Seyfert $v$. Bean

Shaffer $v$. Sutton

Shaw v. Bowman

Shaw v. Phila.

Sheets $v$. Allen

Sheaffer $v$. Sheaffer

Simpson $v$. Hartopp

19

6

I 48

I34

53

106

8

I8

I 47

128

I78

224

$4 \mathrm{I}$

105

Singer $v$. Solomon 6I

Sleeper $v$. Parrish _ $\quad$ I23

Smith $v$. Harvey 9

Snow v. Dill I2r

Snyder's Assd. Est. $\quad 76$

Snyder v. Boring

Snyder $v$. Carfrey $\quad 85,158,163$

Snyder $v$. May

Spencer $v$. Darlington 37,104

Spencer $z$. Clinefelter I05

Springer v. Gas Co. I9r, I92

Steamboat Co. $v$. Hass $\quad$ I54

Steamboat Co. $v$. McCutchen 22

Steel $v$. Frick

Steiner $v$. Marks

103

Stewart $v$. Lawson

Stewart $v$. Martin

Stewart $v$. Roderick

Stockton's Ap.

Stoever $v$. Miller

Stone $v$. Marshall

Stone v. Oil Co.

Stoughton's Ap.

Stover $v$. Cadwallader

Strange 2 Austin

Sturtevant's Ap.

Swartz's Ap. 44

Tate $v$. Reynolds 26

Taylor $v$. Kennelly $\quad 56$

Teller $v$. Boyle 232

Thackray's Ap. 
Tham v. Hamberg

Thomas $v$. Loose

Thomas v. Railroad

Thropp's Ap.

Tiley $v$. Meyers

Timlin $v$. Brown

Tool v. Ins. Co.

Townsend $v$. Underhill, $6 \mathrm{~Pa}$.

PAGE

159
8,10
12,22
55
226
190
${ }^{1}{ }^{133}$

Trout $v$. McDonald

Twibill $v$. Brown

Vaughn $v$. Blanchard

Veditz $v$. Levy

Walbridge $v$. Pruden

Walden $v$. Finch

Walker $v$. Githens

Walker's Est.

Waller v. Coal Co.

Waln v. Conner

Wander $v$. McLean

Ward $v$. Wandell

Ward's Est.

Warren $v$. Forney
I86, I93

200

I35, 136

I 53

102

170

219

46

195

47

175

9 I

137

103
Watts $v$. Fox

Waugh' 85, I5I

Waugh's Exrs. $v$. Waugh I29

White $v$. Arthur 152

Wilgus $v$. Whitehead

Williams $v$. Short

Wilson v. Barns

177

Wistar $v$. Ollis $\quad 154$

Woglam v. Cowperthwaite ro8

Weinmann's Est. 75

Weightman $v$. Harley 139,140

Wheeler $v$. Conrad

Whelen $v$. Boyd

Whitaker $v$. Richards

White $v$. Arthur

Whiting $v$. Opera Co.

Whitton $v$. Milligan

Wiatt $v$. Ewing

Wickey $v$. Fyster

Wiley's Ap.

Wilson $v$. McElroy

Wyke $v$. Wilson

Yeager $v$. Weaver

Young $v$. Oil Co. 



\section{N D E X.}

References are to the sections.

\section{ABANDONMENT}

by tenant, 295 .

forfeiture for not developing mine favored, 421.

\section{ACCEPTANCE}

surrender must be accepted, 325 .

evidence of, 326 .

\section{ACTION}

before justice for rent, 224 .

in court for rent, 226.

of ejectment, 129 .

of replevin, 269.

for waste, $39 \mathrm{r}$.

\section{ACTS OF ASSEMBLY}

I772, March 2I, I Sm. 389.

$\S \mathrm{I}$, requiring a writing for a lease over three years, 20.

$\S \mathrm{I}$, requiring assignment of lease to be by writing, 178 .

1772, March 2I, I Sm. 370.

$\S \mathrm{I}$, providing for manner of proceeding with goods distrained for rent, 244.

$\S 2$, providing penalty on any pound breach or rescous of goods, etc., distrained, 262.

$\S 3$, providing penalty for distraining when no rent in arrear, 258.

$\S 4$, providing that landlord shall be paid one year's rent from sheriff sale of personal property, 234 .

$\S \S 5$ and 6, providing that goods clandestinely removed may be distrained on for thirty days unless sold before seizure, 291.

$\S 7$, providing for a distraint on cattle, corn, grass, etc., 255.

§ 12. for the recovery of possession at the end of term, 336 . 
References are to the sections.

\section{ACTS OF ASSEMBLY-(Continued.)}

I772, March 21, I Sm. 370.

$\S \mathrm{I} 2$, providing for proceeding for possession at end of term when title disputed, 336 .

$\S 14$, providing for a distraint after termination of lease, 245.

I772, March 22, 6 Sm. I82.

$\S 6$, providing for jurisdiction of justice of the peace, 229. I822, March 29, 7 Sm. 520.

$\S$ I, providing for a writ of estrepement to stay waste, 388.

1825, March 25, $8 \mathrm{Sm}$. 4I I.

$\S \mathrm{r}$, providing for a distraint upon goods fraudulently removed in Philadelphia, 295.

$\S I$, providing for possession when tenant moves, 2 I9. 1830, April 3, P. L. I87.

$\S \mathrm{I}$, for possession for non-payment of rent, 202. 1833, April 8, P. L. 315.

$\S \mathrm{I}$, original intestate law, 177 .

1834, Feb. 24, P. L. 77.

$\S 2 \mathrm{I}$, preference for year's rent in case of death of tenant, 230.

1834, Feb. 24, P. L. 77.

$\S 30$, providing that executors of tenant for life may recover rent to time of the decease of such tenant, 98 . I836, June I3, P. L. 568 .

$\S \S 44$ and 50 , providing for collecting rent by foreign attachment, 243 .

June I6, P. L. 784 .

$\S 13$, providing a remedy by an injunction for waste, 392 . June 16, P. L. 755 .

$\S 83$, providing for the payment of one year's rent from sheriff's sale of personal property, 234 .

1849, April 9, P. L. 533.

$\S 1$, the $\$ 300$ exemption law, 283 .

I855, April 27, P. L. 368.

$\S 8$, providing for tenant's mortgaging leases and machinery, 193.

April 27, P. L. 368 .

$\S 3$, providing for inheritance by illegitimate children, 177 . 1860, March 31, P. L. 382.

$\$ \S 2 \mathrm{I}$ and 22 , relating to forcible entry and detainer, $33 \mathrm{I}$. 1863, Dec. I4, P. L. I125.

$\S \mathrm{I}$, for possession at the end of lease, 352 . I865, Feb. 28, P. L. 253.

$\S \mathrm{I}$, for possession at the end of lease in case of its loss, 375. 
References are to the sections.

ACTS OF ASSEMBLY-(Continued.)

I867, Feb. 20, P. L. 30.

$\S$ I, providing that the act of Dec. I4, I863, shall apply when owner has acquired title by descent or purchase, 354 .

1869, April I7, P. L. 69.

$\S \mathrm{I}$, exempting sewing machines from distraint for rent, $28 \mathrm{I}$.

June 25, P. L. I275.

$\S$ I, providing that an appeal under act of Dec. I4, I863, will be a supersedeas in Philadelphia, 355.

I876, May 13, P. L. I7I.

$\S \mathrm{I}$, exempting rented pianos from distraint, 280 .

I878, June I2, P. L. I.

Giving preference of wages over rent, 240. I883, April 19, P. L. 9.

$\S 3$, providing for a distraint on tenant's goods for taxes, 296.

I883, June 5, P. L. 88.

§ $\mathrm{I}$, providing that illegitimates may inherit from each other, 177.

1885, June 3, P. L. 61.

$\S \mathrm{I}$, liability of landlord for fire escapes, 156.

1887, April I3, P. L. 53.

$\S \mathrm{I}$, providing that adopting parents shall inherit; I77.

May 18, P. L. 118.

$\S \mathrm{I}$, requiring written consent of landlord for tenant to bind property for mechanics' liens for repairs, 313 .

I889, May 13, P. L. 197.

$\S \mathrm{I}$, providing for mortgages of royalties for mines, $20 \mathrm{I}$. I89I, May 20, P. L. IO2.

$\S \mathrm{I}$, providing for mortgaging of ores, $20 \mathrm{I}$.

May 26, P. L. 122.

$\S \mathrm{I}$, providing for the payment of rent in case of assignment for the benefit of creditors, 189 .

I893, May 23, P. L. II7.

$\S \mathrm{I}$, providing for fees of justices, 405 .

June 8, P. L. 344 .

$\S \mathrm{I}$, giving married women power to lease, 38 .

I895, June 24, P. L. 238.

providing for liability of tenants in common in possession to co-tenants, 50 .

I899; March I, P. L. 3.

$\S \mathrm{I}$, providing for fees of constables, 405.

\section{ADMINISTRATOR}

cannot lease, 52. 
References are to the sections.

AGENTS

See LeAsE, $\$ \S 23$ to 32 .

AGREEMENTS FOR A LEASE

directions for preparing, I.

specific performance will be decreed, 2 .

damages for breach of, 3 .

where a tenant under a parol agreement for a lease is let into possession and makes improvements, 4 .

lease completed by an actual entry of tenant, 5 .

AGREEMENT TO SELL TO TENANT

practical directions, 466 .

covenant to sell, 123 .

\section{AGRICULTURAL FIXTURES}

See Fixtures, 152.

\section{AMICABLE EJECTMENT}

covenant for, 129.

if tenant has not paid his rent punctually he must be warned before entry of judgment, I3o.

for a purchaser to have benefit of, lease should be assigned to him, I3I.

no appeal to Supreme Court in case of, 132.

position of under-tenants in case of, 133 .

possession by those holding paramount title in case of, 134 .

form for entry in court of, 534 .

practical directions as to necessity for proper description in, 505 .

APPEAL

to Supreme Court under act of 1772 for possession, 350 .

to court of common pleas under act of 1830 for non-payment of rent, 215 .

to Supreme Court under act of 1830 for non-payment of rent, 218 .

to court of common pleas under act of 1863 for possession, 370 .

to Supreme Court under act of 1863 for possession, 374 .

\section{APPORTIONMENT OF RENT.}

in case of a sale of reversion in parts, 94.

payable to tenants for life under act of 1834,98 .

payable in grain to life tenant, 99.

\section{APPRAISEMENT}

in case of a distraint, 277.

forms for, 526 .

in case of $\$ 300$ exemption law, 284 .

form for, 533 . 
References are to the sections.

ASSESSMENTS

protection to tenant from agreement to pay assessments, 496 .

ASSIGNMENT OF LEASE

covenant not to assign, rog.

construed strictly, Iro.

an assignment by law not a breach, III.

form for, 523 .

must be by writing, 178 .

difference between, and underletting, I79.

position of under-tenant, I80.

power of tenant to assign, $\mathrm{I} 8 \mathrm{I}$.

tenant bound to pay rent after he assigns, 182 .

assignee liable as long as he holds title, 183.

implied indemnity of assignee, 184 .

when tenant dies, 186 .

when representatives become personally liable, 187 .

directions in taking, 469 .

assignee assigning liable if he retains interest, 501 .

necessity of having a clause for forfeiture for a breach of covenant not to assign, 502.

danger of breach of covenant not to assign by taking partner, 505 .

ASSIGNMENT FOR THE BENEFIT OF CREDITORS

assignee has right to accept lease or not, I 88 .

landlord's preference in case of, 189.

liability of assignee for rent, I9I.

agreement of assignee with sheriff for sale of goods, 190.

assignee cannot lease, 59 .

\section{ASSIGNEE}

extension of right to terminate lease to, $48 \mathrm{I}$.

ATTACHMENT

of rents by attachment-execution, 242 .

foreign attachment, 243 .

\section{BANKRUPTCY}

collection of rent in case of, 233.

BREACH OF THE PEACE

See Forcible Entry and Detainer. should not be made by re-entry, $12 \hat{6}$.

\section{CERTIORARI}

under act of $\mathbf{I 7 7 2}$ for possession, 348 .

under act of 1830 for possession, 216 .

under act of 1863 for possession, 373 . 
References are to the sections.

\section{COLLECTION OF TAXES}

by distraint on tenant's goods, 296.

\section{COLLECTING RENTS}

by suit before justices of the peace, 224 .

the hearing, 225 .

in court, 226.

in equity by receivers, 227 .

during administration of receivers, 228.

loss of rents collected by receiver from sub-tenants, 229.

in case of death of tenant rent not exceeding for one year preferred, 230.

landlord to present claim to orphans' court, 23 I.

in bankruptcy, in case of, 232.

not apportioned under act of $1898,233$.

from sheriff's sales.

act of 1836,234 .

apportioned, 235 .

landlord should notify sheriff of claim, 236.

note taken no waiver of, 237.

goods must have been liable to distraint, 238 .

preference of wages over rent, act of April 9, 1772, 240.

claim for wages may be sold, 241 .

when claimed by two adverse parties, 239.

by attachment-execution.

the remedy, 242.

by foreign attachment.

the remedy, 243 .

\section{CONSTRUCTION}

\section{rules for, 9.}

when doubtful tenant favored, 498 .

\section{CO-PARTNERS}

lease by, 33,34 .

lease to, 35 .

\section{CORPORATIONS}

may make leases as natural persons, $4 \mathrm{I}$.

may contract without writing, 42 .

leases to foreign, 43 .

officers must be authorized to lease, 44 .

cannot disable itself from performing public duties by a lease, 45 .

seal of, not necessary to hold in assumpsit, 46 .

may ratify agent's acts, 47 .

\section{COVENANTS}

running with the land, 103. 
Reierences are to the sections.

COVENANTS-(Continued.)

implied, run with the land, 104.

when run with the land, I05.

assignees bound by, when running with the land, 106 .

examples of running with the land, ro7.

to pay rent, 108.

not to assign or underlet, 109.

are construed strictly, IIo.

assignment by law not a breach of, III.

as to use and occupation, II2.

landlord not bound to repair, II 3 .

repairs a tenant is bound to make, II4.

of tenant to repair, II5.

tenant is not bound under, in case of damage by act of God or public enemies, Ir6.

tenant cannot charge landlord for permanent repairs made without his authority, 117.

of tenant to repair minor to that of the tenant to pay rent, II8.

measure of damages when landlord breaks his covenant to repair, I19.

tenant not relieved from loss in business during repairs, 120.

that improvements shall remain, dangerous, 121 .

definition of the word improvement, 122.

of landlord to sell to tenant, 123 .

for re-entry, 124 .

requisites before entry, 125 .

there must not be a breach of the peace in making entry, 126.

in Pennsylvania a re-entry is not necessary for a forfeiture, 127.

waiver of, forfeiture, 128 .

for amicable action and confession of judgment in ejectment, 129.

See Amicable Ejectment.

implied for quiet possession, 135.

to protect tenant against paramount claims, 136 .

to use property in tenant-like manner, 137.

as to farming, 138 .

\section{CROPS}

way going, definition of, 301 .

who entitled to, 302 .

straw included in, 303 .

grain sown in spring not included, 304

may be sold by tenant, 305 .

the protection of, 306 .

in case of execution, $30 \%$. 


\section{CROPS-(Continued.)}

landlord not entitled to grain as rent until delivered, 309.

as rent will pass to purchaser at orphans' court sale, 3 Io.

payable as rent, growing at death of landlord, will go to heirs, 3 II. covenants as to, 507, 508, 510, 5II, 512, 513, 514, 515 and 516. covenants as to farming, 138 .

necessity for having time fixed for delivery of landlord's share of crops, 495.

\section{CROPPER}

definition of, 308 .

\section{CUSTOM}

way going crop, 301 .

\section{DATE}

of lease, $\mathbf{2 1}$.

\section{DEATH OF LESSEE}

collection of rent in case of, $230,231$.

\section{DEATH OF LESSOR}

transfer of lease in case of will, 176.

transfer of lease in case of intestacy, 177.

\section{DISTRAINT FOR RENT}

\section{See Replevin; Forms.}

act of March 21, 1772, regulating, 244.

after termination of lease, 245.

by lessor who has conveyed, 246 .

by executors and administrators, 247 .

by assignee of the reversion, 248 .

by joint tenants, 249 .

by tenants in common, 250 .

by guardians, $25 \mathrm{I}$.

by receivers, 252 .

by heirs, devisees, etc., 253.

for what rent, 254 .

goods liable to, 255 .

goods privileged from, 256 .

authority given for, 257 .

penalty for, when no rent due, 258.

for more rent than is due, 259.

entering premises to make, 260.

upon the goods, 261 .

rescue of goods taken by, 262 .

interference with proceedings for, 263.

anreasonable or excessive, 264 . 
References are to the sections.

\section{DISTRAINT FOR RENT-(Continued.)}

placing watchman in case of, 265 .

leaving goods on premises in case of, 266 .

notice to tenant of, 267.

tender of rent upon a, 268 .

liability for, of goods of a stranger, 276 .

appraisement of goods upon a, 277.

sale of goods upon a, 278 .

manner of sale upon a, 279.

exemption of rented pianos in case of, 280 .

exemption of sewing machines in case of, 28I.

liability of goods sold according to instalment plan for, 282.

three hundred dollar exemption law in case of, 283.

appraisers under exemption law in case of, 284 .

under-tenants cannot claim benefits of exemption in case of, 285 . refusal of exemption in case of, 286 .

who can claim exemption in case of, 287.

when claim for exemption should be made in case of, 288 .

request of appraisement in case of claim for exemption upon a, 289.

how claim for exemption to be made when tenant absent in case of, 290.

rights to, in case property is fraudulently removed under act of $1772,291$.

goods of a stranger not to be followed in case of, 292.

goods sold exempt from, in case of removal, 293.

must be for rent due at time of removal, 294.

right to, for rent not due under act of, 1825, 295.

providing for distraint after removal of tenant, 477 .

\section{EJECTMENT}

See Amicable Ejectment.

\section{EMBLEMENTS}

See Crops.

definition of, 297.

growing grass not to be taken as, 299.

things not of annual growth not, 299.

right to, lost by forfeiture of lease, 300 .

\section{EMINENT DOMAIN}

See Rented Property Taken for Public Use. see if devised premises in Philadelphia can be taken for public use, 456.

\section{ENCUMBRANCES}

examination as to, 458 . 
References are to the sections.

\section{EQUITY}

a specific performance of an agreement for a lease will be decreed in, 2.

remedy by injunction in, for waste, 392 .

\section{ESTREPEMENT}

writ of, 390 .

\section{EVICTION}

in part does not suspend the whole rent when tenant remains, 315 . physical expulsion not necessary for, $3^{17}$.

operation of, against current rent, 320 .

by an injunction, 321 .

not by conduct not depriving tenant of the use of property, 322. waiver of, by paying rent, 323 .

when landlord takes possession in case of tenant's desertion, . .I8 landlord using a way, 319 .

when landlord takes possession after a fire, 3 I 6 .

\section{EVIDENCE}

parol, admissible in case of fraud, aceident or mistake, 6.

in some other cases, 7 .

agreement in writing to exclude, 8.

\section{EXECUTOR}

unless made a trustee, cannot lease, 54 .

in case he lias a mere power to sell, 55 .

in case of a trust to sell, but not to rent, 56 .

a lease a part of decedent's assets, 186 .

\section{EXEMPTION}

under $\$ 300$ law, 283.

appraisers appointed, 284 .

under-tenants cannot claim, 285.

refusal of exemption, 286 .

who can claim, 287.

when claim should be made, 288 .

request for appraisement, 289 .

how clain made when tenant absent, 290.

of rented pianos from distress, 280 .

of sewing machines from distress, $28 \mathrm{r}$.

liability of goods sold under instalment plan to distress, 282.

\section{FARM LEASE}

See Crops.

form for, 508 .

on shares, 509 .

on shares, short form, 510. 
References are to the sections.

\section{FARM LEASE-(Continued.)}

covenant in that lessee shall fallow land and mow but once year, $5 \mathrm{II}$.

may dispose of hay and straw, 5 I2.

shall plant clover, 5 I3 .

shall use hay, dung, etc., 5 I 4 .

fire clause in No. I, 515 .

fire clause in No. 2, 516 .

protecting landlord in, 485 .

prevention of the termination of farm leases by death of tenant, 475 .

FEES

of constables, 405 .

of justices, 405 .

of watchmen, 406 .

FIRE

tenant liable to pay rent if premises destroyed by, 96,97 .

clause for farm lease, $515,516$.

clause for lease of dwelling. 517.

clause for lease of a business property, 518 .

\section{FIXTURES}

domestic, I5o.

trade, I5I.

agricultural, 152.

not removed at end of lease, 153.

tenant's, liable to execution, 154 .

notice to landlord upon constable's sale of, 155 .

duty of placing fire escapes in Philadelphia, 156.

of tenant to be protected in case of renewed leases, 467 .

protecting landlord's rights to fixtures at end of lease, 500 .

FORCIBLE ENTRY AND DETAINER

act of assembly relating to, 33 I.

must be a breach of the peace to constitute, 332 .

to constitute there must be violence, 335 .

\section{FORCIBLE DETAINER}

what constitutes, 333 .

tenant holding over not liable for, 334 .

\section{FORMS}

a lease, 507 .

farm lease, 508 .

farm lease on shares, 509.

farm lease on shares, short form, 510.

covenant that lessee shall fallow the land and mow but once year, 5 II. 
References are to the sections.

FORMS-(Continued.)

covenant that lessee may dispose of hay and straw, 512.

covenant to lay down part of the ground with clover, etc., 513. covenant that lessee shall use the hay, dung, etc., on the premises, 514 .

fire clause for farm lease, No. I, 5 I5.

fire clause for farm lease, No. 2, 516.

fire clause for a dwelling, 517 .

fire clause for a business property, 518 .

to protect against assignment of lease, 519 .

for insertion after ejectment clause, 520.

giving an option to purchase, $52 \mathrm{r}$.

surety for tenant, $\mathbf{5 2 2}$.

assignment of lease, 523 .

surrender of lease, 524 .

distress warrant, 525 .

notice of distraint, 526 .

affidavit of appraisers and appraisement, 527.

consent of tenant to permit distrained goods to remain, 528 .

notice of constable's sale, 529 .

claim for benefit of exemption law, 530 .

summons of appraisers, 53r.

affidavit of appraisers and election, 532 .

appraisement of exempted goods, 533 .

amicable action and judgment in ejectment, 534 .

notice to quit for non-payment of rent under act of 1830,535 .

complaint, 536 .

summons, 537 .

writ of restitution, 538 .

record, 539.

notices to quit at end of lease, 540 .

complaint for possession under act of 1772,541 .

precept to the sheriff, 542 .

inquisition, 543 .

record, 544 .

summons to third party claiming title, 545 .

complaint for possession under act of 1863,546 .

summons, 547 .

record, 548 .

writ of restitution, 549 .

notice in case of lost lease, 550 .

second notice, $55 \mathrm{I}$.

notice when tenant unable to answer first notice, $\mathbf{5 5 2}$.

\section{FRAUD}

parol evidence admissible in case of, 6 .

false representations by lessee, 455 . 


\section{INDEX.}

References are to the sections.

FRAUDULENT REMOVAL

right to distrain in case of, $29 \mathrm{r}$.

goods of a stranger not to be followed, 292.

goods sold exempt in case of, 293.

rent must be due at time of, 294 .

right to collect rent not due, 295 .

\section{FURNITURE}

list of, should be annexed to lease when rented, 62 .

\section{GRANTEE}

rent due after a sale, 86 .

custom in Philadelplia to apportion rent, 87 .

\section{GROWING CROPS}

See Crops.

\section{GUARDIAN}

leases by. 37 .

rights of, to lease mines, $4 \mathrm{IO}$.

\section{HEIRS}

rights of, under intestate laws, 177.

INABILITY OF TENANT TO DISPUTE THE TITLE OF HIS LANDLORD

the rule as to, and its operation, I39.

liability of tenant to forfeit his lease, I 40.

case of collusion with tenant, I4I.

case of fraud by landlord, I42.

\section{IMPLIED TENANCY}

by the payment of rent, 75 .

\section{IMPLIED COVENANTS}

run with the land, IO4.

\section{INSURANCE}

by tenants distinguished from other insurance, 314 .

protecting insurance from conduct of tenant, 488 .

\section{INTEREST}

on royalties, 443 .

LEASE

See Term; Rent; Amicable Ejectment; Inability of LandLORD to Dispute Titles of LANDlord.

directions for preparing, I.

specific performance will be decreed, 2 .

damages for a breach of an agreement for, 3 . 
References are to the sections.

LEASE-(Continued.)

when a tenant under a parol agreenent for, is let into possession and makes improvements, 4.

completed by an actual entry, 5 .

parol evidence admissible in case of fraud, accident or mistake in, 6 .

parol evidence admissible in some other cases, 7 .

agreements in writing to exclude verbal understandings as to, $\mathbf{8}$. rules for construction of, 9 .

definition of, Io.

distinction between, and a license, II.

incorporeal things may be granted, I 2.

lease of, in farm on shares, $\mathrm{I} 3$.

implied renting.

in case a tenant remains with permission and pays rent after leasc expires, 14.

occupancy under an agreement for a lease, 15 .

occupancy of land where no agreement to pay rent, I6.

where a purchaser at sheriff's sale elects not to take tenant, 17 .

where a tenant remains in possession after the end of lease without consent, 18 .

a tenant in possession under a, void, 19.

act of 1772 requiring written lease, 20 .

mistake or omission of date of, 21 .

mistakes or omissions of names of, 22.

by agents.

the manner of signing and sealing in case of, 23.

ratification of a parol lease void under the statute of frauds in case of, 24.

should have sealed authority to make a sealed lease, 25.

sealing leases without authority personally liable, 26 . not under seal, 27.

parol evidence admissible to prove a lease not under seal as principals, 28 .

making leases in their own names deprives their principals of their righits as landlords, 29.

when agent makes a lease without disclosing his principal, tenant cannot deny that the agent is not landlord, 30 .

agents without authority in writing may make a lease not over three years, $3 \mathrm{I}$.

personal liability of agents for their contracts when they do not disclose their principals, 32 .

by partners.

should be sealed by all, 33 .

lease by one of, of partnership property, 34 . 
References are to the sections.

LEASE-(Continued.)

to partners.

if they take leases in their own names for the firm, hold in trust for the firm, 35 .

by minors, 36 .

by guardians, 37 .

by married women, under act of 1893.38 .

to married women, 39.

by tenants ior life must terminate at death, 40 .

by corporation,

corporations may lease as natural person, 41 .

may contract without writing, 42.

officers of, must be anthorized to lease, 44 .

cannot disable itself irom performing public duties by a lease, 45 .

seal of, not necessary to hold in assumpsit, 46 .

may ratify agent's acts, 47 .

by tenants in common.

may make joint or separate lease, 48 .

when a joint lease made by, they must sue jointly, 49 .

liability of, to pay co-tenants not in possession, 50.

by trustees and executors.

powers of, limited by trusts, 51 .

administrators cannot lease, 52 .

until real estate is sold to pay debts, rents go to heirs or devisees, 53.

executor, unless he is made a trustee, cannot lease the same,

54.

in case executors have a mere power to sell real estate, 55.

in case of a trust to sell, but not to rent, 56 .

power of trustees to agree to a renewal of a lease, 57 .

case of personal liability under a lease, 58 .

assignee for the benefit of creditors cannot lease, 59.

description of property in, not necessary to particularly describe,

60.

ambiguous supplied by evidence outside lease, $6 \mathrm{I}$.

list of furniture should be annexed to lease, 62 .

intention of what is leased from actual use, 63 .

on the wrong corner, 64 .

exceptions and reservations in lease, 65 .

implied grant of things necessary for use of property, 66 .

authority of landlord to enter after he has leased, 67 .

where landlords do not sign, 143.

where tenants do not sign, 144 .

seals of, 145 . 
References are to the sections.

LEASE-(Continued.)

witnesses to, 146 .

erasures in, 147 .

interlineations in, 147 .

stamps on, I48.

recording, I 49 .

necessity of, when tenant does not take possession, 494.

\section{MECHANICS' LIENS}

power of tenant to bind, 312 .

act of 1887 requiring written consent of landlord to bind, 3 I3.

\section{MINING LEASES}

mining leases in Pennsylvania, 407.

mining right distinct from surface right, 408.

rights of tenant for life, 409.

rights of guardians to lease, 4 IO.

tenant bound to work mine, 4II.

clause for re-entry necessary, 412 .

incidental rights of mining tenant, $4 \mathrm{I} 3$.

right of support, 4I4.

loss of springs on surface, $4 \mathrm{I} 5$.

tenant cannot open mines, $4 \mathrm{I} 6$.

rent to be paid, though no clay be taken out, not damages, $4 \mathrm{I}$.

no warranty of coal, $4 \mathrm{I} 8$.

relief in case of mistake, $4 \mathrm{I} 9$.

tenants taking partners, 420 .

forfeiture for not developing favored, 421 .

manner of conveying in case of sales of minerals, 422.

questions as to whether there is a sale, a lease or right to take coal without a sale, 423 .

mining by tenants in common, 424 .

oil and gas leases, 425 .

right to mine for oil or gas is necessarily exclusive of the right of the landlord to mine, 426 .

liability to pay compensation in case of exhaustion of mines, 427 . obligation to drill through land worthless for oil or gas, 428 . mortgages of mineral leasehoids, 429.

perpetual lease of ore lands, 430.

options to drill or to pay rent, 43I.

provisions for the forfeiture of an oil or gas lease for the benefit of the lessor only, 432.

right of mining tenants to pollute streams, 433 .

liability for manufacturing coke and injuring crops, etc., of adjoining premises, 434.

as to whether or not a mining lease has been forfeited for not operating, 435 . 
References are to the sections.

\section{MINING LEASES-(Continued.)}

rights to make openings to reach coal, 436 .

agreements for diligence in drilling and working for oil, etc., 437. in agreements for coal leases time is of the essence of the contract, 438 .

relief against forfeiture of an oil and gas lease for non-payment of rent, 439 .

partnership in mineral leaseholds, 440.

relief against forfeiture of mining leases, 44I.

a lease for exploration for oil ceases when exploration finished, 442.

interest on royalties, 443.

tenant will not be compelled. in equity to test land for oil or gas if there is no fraud, 444 .

covenants to pay royalties run with the land, 445 .

when lessee to follow his own judgment in sinking additional wells, 446.

the meaning of the phrase, "to continue so long as oil or gas are produced in paying quantities," 447.

necessity for having oil leases recorded, 448.

jurisdiction in equity for account of gas, etc., 449.

rent may be payable in oil or gas, 450 .

liability of assignee of an oil or gas lease for the payment of royalties, $45 \mathrm{I}$.

distinguishing between a lease and sale granting mining rights, 489.

necessity of a particular description of the extent of a right to mine, 490 .

ascertaining if any old mining leases are outstanding, $49 \mathrm{I}$.

protection to landlord who reserves the surface in a right to mine, 492.

\section{MORTGAGE}

by tenant under act of 1855,193 .

lease must be recorded under act, 194 .

machinery put in after mortgage under act, 195.

- a breach of covenant not to assign, 196 .

act not restricted to mining leases, 197.

fixtures and machinery under act cannot be removed without consent of mortgagee, 198.

of mining rights under act of $1853,199$.

of ores, etc., under act of $1891,200$.

by landlord under act of 1899,201 .

\section{NEGLIGENCE AS TO RENTED PROPERTY}

liability of owners, 379 .

in case of an open grate, $38 \mathrm{r}$. 
References are to the sections.

NEGLIGENCE AS TO RENTED PROPERTY-(Continued.) liability between tenants, 385 .

depending upon the obligation to repair, 386.

of contractor for injury, 393 .

for leakage from a cesspool, 394.

for not repairing sidewalk, 395 .

remedy in case tenant commits waste, 387 .

by an injunction for waste, 392 .

by suit for waste, 39 .

defects before renting, 376 .

landlord employing plumber, 378 .

and tenant may both be liable, 380 .

may sue at the same time, 382 .

where landlord interferes with tenant, 383 .

tenant injures property, 384.

property rented is unfit for use, 377 .

act of 1882 as a remedy for waste, 388 .

order to permit inspection of waste, 389 .

writ of estrepement, 390 .

NOTICE TO QUIT

See Forms; Proceedings for Possession.

OPTIONS TO PURCHASE

giving tenant right, 466 .

PAROL TESTIMONY

provision prohibiting to affect written leases, 470 .

PARTNERS

leases by and to, 33, 34, 35 .

PENALTY

making penalty to be paid as rent, 468 .

POSSESSION

See Procefdings for Possession Under Following Acts: proceedings for, under act of 1772,336 to 351 .

proceedings for, under act of 1825,219 to 223 .

proceedings for, under act of 1830,202 to 218 .

proceedings for, under act of 1863,352 to 374 .

proceedings for, under act of 1865,375 .

PRACTICAL DIRECTIONS FOR RENTING

examination of the property, 452.

see what neighbors can do in diminishing the value of demised premises, 453.

inquiries of landlord before renting, 454 .

false representations by lessee, 455 . 
References are to the sections.

PRACTICAL DIRECTIONS FOR RENTING-(Continued.)

see if demised premises in the city of Philadelphia are liable to be taken for public use, 456 .

examination of the title of the landlord, 457.

examination as to encumbrances, 458 .

see if lease can be destroyed by an orphans' court sale, 459 .

see if there is a liability for a distraint for taxes, 460.

obtaining rights for a show case, $46 \mathrm{r}$.

obtaining sign rights by tenant, 462 .

provisions in case of fire or other casualty, 463 .

directions for making rents certain for distraint and possession, 464.

directions in case of an underletting, 465 .

giving rights to tenants to purchase, 466 .

fixtures of tenant to be protected in cases of renewed leases, 467 . making a penalty to be paid as rent, 468 .

directions in taking assignments of leases, 469 .

provisions prohibiting parol testimony to affect written leases, 470.

restrictions as to the use of demised premises, 471 .

making rent due in advance by occurrences after the lease, 472 . providing against the liability of the owner for nuisances, 473 .

prevention of defences being waived by paying rent or other action, 474.

prevention of the termination of farm leases by death of tenant, 475.

provisions for amicable ejectments, 476 .

providing for distraint after removal of tenant, 477.

giving sub-tenants the benefit of the exemption law, 478 .

providing for surety in cases of extensions of lease, 479 .

getting the consent of the surety to alter lease, 480 .

extension of right to terminate lease to assignees, etc., 481.

danger of landlord losing his right to rent by the non-performance of an entire contract, 482 .

cautions in preparing agreements for the extension of term and for options, 483 .

necessity of a consideration for an agreement to change the terms of a lease, 484 .

protecting landlord in farm leases, 485 .

making the payment of taxes, clarges, etc., as rent, 486 .

necessity of reading leases, 487 .

protecting fire insurance from conduct of tenant, 488 .

distinguishing between a lease and sale granting mining rights, 489.

necessity of a particular description of the extent of a right to mine, 490 . 
References are to the sections.

PRACTICAL DIRECTIONS FOR RENTING-(Continued.) ascertaining if any old mining leases are outstanding, $49 \mathrm{I}$. protection to landlord who reserves the surface in a lease to mine, 492.

binding remainderman in case of a lease by tenant for life, 493. necessity of recording oil lease when tenant does not take possession, 494 .

necessity for having time fixed for delivery of landlord's share of crops, 495.

protection of parties in agreements to pay for taxes, charges, assessments, etc., 496 .

dangers in using clause that landlord may change terms of lease, 497.

in case of doubtful construction, the tenant favored, 498.

fixing a time for the tenant to perform an agreement to make improvements, 499.

protecting landlord's right to tenant's fixtures at the end of the lease from levy, etc., 500.

if an assignee assigns his lease and retains an interest he will remain liable, 501 .

necessity of having a clause for forfeiture for a breach of a covenant not to assign, 502 .

guarding against the breach of trifling covenants giving the right to recover possession, 503 .

in case a tenant agrees to use or not to use demised premises for a certain business or purpose, 504 .

danger of there being a breach of a covenant not to assign lease by taking a partner, 505 .

necessity for a description to locate premises in leases or amicable ejectments, 506 .

giving right to distrain off the demised premises, 506.*

\section{PROCEEDINGS FOR POSSESSION AT END OF TERM UNDER} ACT OF MARCH 2I, 1772.

\section{See Forms.}

words of the act, 336 .

who are entitled to the benefit of the act, 337 .

rent must be certain, 338 .

notice to quit, 339 .

service of notice to quit, 340 .

complaint, $34 \mathrm{I}$.

venire to the sheriff, 342 .

service of summons, 343 .

proceedings before the jury, 344 .

proceedings when the title is disputed, 345 .

finding of the jury, judgment and writ for possession, 346.

proper form for the record, 347. 
References are to the sections.

PROCEEDINGS FOR POSSESSION AT END OF TERM UNDER ACT OF MARCH 21, 1772-(Continued.)

removal by certiorari, 348 .

what can be shown at hearing upon certiorari, 349 .

appeal to the Supreme Court, 350 .

tenant may traverse the inquisition in an action of ejectment, $35 \mathrm{I}$.

PROCEEDINGS FOR POSSESSION AT END OF TERM UNDER ACT OF DEC. 24, 1863.

See Forms.

words of the act, 352 .

power of justice of the peace extended to aldermen, 353 .

act extended to assignees, 354 .

appeal will be a supersedeas in Philadelphia, 355 .

tenancy to be established by parol or written agreement, 356 .

notice to quit, 357 .

tenant not bound to give notice to quit, 358 .

notice given by assignee of lease, 359 .

verbal notice, 360 .

time of giving notice, $36 \mathrm{r}$.

no limitation for landlord to proceed on notice, 362 .

notice to quit may be waived, 363 .

service of notice for possession, 364 .

complaint, 365 .

summons, 366 .

service of summons, 367 .

hearing, 368 .

warrant for possession, 369 .

appeal, 370 .

judgment, $37 \mathrm{I}$.

record, 372 .

certiorari, 373 .

appeal to Superior Court, 374 .

PROCEEDINGS FOR POSSESSION AT END OF LEASE IN CASE OF ITS LOSS

See Forms.

act of Feb. 28, I865, relating to same, 375 .

PROCEEDINGS FOR POSSESSION FOR NON-PAYMENT OF RENT UNDER ACT OF APRIL 3, I830.

See Forms.

the act, 202.

who may have the benefit of, 203 .

the rent due must be certain, 204 .

the notice to quit, 205 .

by whom notice can be given, 206 .

to whom notice should be given and manner of service, 207 . 20 
References are to the sections.

PROCEEDINGS FOR POSSESSION FOR NON-PAYMENT OF RENT UNDER ACT OF APRIL 3, I839-(Continued.)

payment of rent on removal, 208.

the complaint, 209.

summons, 210.

the service of the summons, 2 II.

the hearing, 212 .

the necessary proof, 2 I3.

the judgment, 2I4.

appeal, 215.

certiorari, 216.

the execution, 2 I 7 .

appeal to Supreme Court, 218.

PROCEEDINGS FOR POSSESSION OR SECURITY WHEN

TENANT REMOVES IN PHILADELPHIA

act of March 25, I825, 219.

tenant must remove, 220 .

notice must be signed by landlord or his agent, $22 \mathrm{I}$.

complainant must show a lease for years, 222 .

tender of rent, 223.

\section{PUBLIC USE}

property taken for.

See Rented Property Taken for Public Use.

\section{RECORDING}

necessity of recording oil lease when tenant does not take possession, 494 .

\section{RENT}

in what payable, 82 .

what may issue out of, 83 .

interest on, 84 .

when no time fixed for payment of, 85 .

due after a sale, 86 .

custom in Philadelphia to apportion, 87.

tenant bound by his covenant to pay, although he assigns his lease, 88.

due landlord before he dies goes to his executor as personal property, 89.

due landlord after he dies goes to his heir or devisee, 90.

agreement of tenant to pay assessments, $9 \mathrm{r}$.

notice to lessor on contingency releasing a lessee, 92.

landlord leaving a number of children, each child is entitled to his or her share of, 93 .

apportionment of, in case of a sale of reversion in parts, 94 . payable in advance upon contingency, 95. 
References are to the sections.

RENT-(Continued.)

tenant bound by his covenant to pay though property is burned, 96.

instances of losses to tenants for the want of an exemption from the payment of, in case of fire, 97.

made payable to tenant for life apportioned under act of $1834,98$. payable in grain, etc., apportioned under act of $1834,99$.

when payable in grain, not due until delivered, Ioo.

interest of landlord in share of grain cannot be taken in execution before severance, Ior.

good will of demised premises, 102.

\section{RENTED PROPERTY TAKEN FOR PUBLIC USE}

constitutional provision relating to, 396 .

difference when State takes, 397.

damages awarded to landlords and tenants for, 398.

landlords and tenants may unite to recover damages for, 401 .

effect of taking, on liability for rent of, 403 .

what damages can be recovered for, 404.

party wall taken down by public authority, 399 .

tenant can recover damages to building erected before ordinance

for removal, 400 .

land may be cultivated until possession taken, 402 .

\section{REPAIR}

landlord not bound to, II3.

repairs a tenant is bound to make, II4.

express covenant of tenant to, II5.

tenant not bound to, injuries by act of God or public enemies, II6.

tenant cannot charge landlord for permanent repairs made without

his authority, II7.

agreement of landlord to, minor to that of tenant to pay rent, $\mathrm{I} I 8$. measure of damages when landlord breaks his agreement to, IIg. tenant not relieved from loss in business during repairs, I20.

\section{REPLEVIN}

writ of, 269 .

time for issuing writ of, 270 .

order for the writ of, $27 \mathrm{I}$.

entering security for, 272.

the pleadings in, 273 .

trial and judgment in, 274 .

the proper remedy for illegal distraint upon stranger's goods, 275 .

SEAL

kind of, 145 .

\section{SHOW CASE}

agreement in lease for, 461. 
References are to the sections.

\section{SIGN RIGHTS}

agreement in lease for, 462 .

\section{STAMPS}

on leases, $\mathbf{I} 48$.

\section{SURETY FOR TENANT}

when liable to be sued at once, I57.

covenant of, runs with the land, 158 .

tenant bound to exonerate, I59.

position of in case of tenant holding over, 160 .

alteration of a lease affects, r6r.

discharge of, by variation of lease, 162 .

discharge of, if landlord allows goods distrained to be removed, 163.

discharge of, by giving time, 165 .

liable under a void lease, 166 .

demand of rent by landlord, 164 .

providing for surety in case of extension of lease, 479.

getting consent of surety to alter lease, 480 .

\section{SURRENDER}

by parol of lease for more than three years, 324 .

must be accepted, 325 .

evidence of acceptance of, 326 .

to agent, 327 .

effect of, on request, 328 .

by a tenant does not extinguish the term of a sub-tenant, 329 .

effect of silence of landlord upon, 330 .

\section{TAXES}

distraint for, 296.

see if there is a liability for taxes, 460 .

\section{TENANT FOR LIFE}

binding remainderman, 493.

\section{TENDER}

to stop a distraint, 268 .

\section{TERM}

estate for years, 68 .

at will, 69 .

tenancy from year to year, 70 .

tenancy from year to year by express agreement, 74 .

tenancy from quarter to quarter, $7 \mathrm{r}$.

perpetual leases, 72 .

not stated in lease, 73 .

implied by the payment of rent, 75 . 
References are to the sections.

TERM-(Continued.)

landlord may elect to treat tenant holding over after lease as tenant or trespasser, 76 .

tenant from month to month may terminate lease at end of any month, 77 .

a lease from year to year, at the pleasure of the parties, 78 .

the beginning and end of lease, 79 .

continuation of lease at option of tenant, 80 .

agreements for extension of, and options, 8I, 483 .

\section{TERMS OF LEASE}

necessity of consideration to change, 484 .

TIME

the essence of the contract in oil leases, 438 .

\section{TRANSFER OF INTEREST OF LANDLORD IN DEMISED PREMISES}

by a sale of demised premises, 167 .

by an assignment of the landlord for the benefit of creditors, 168 .

by a conveyance to trustees to collect rents, etc., I69.

by the will of the landlord, 176 .

by descent, 177 .

by a judicial sale, Izo.

notice of affirmation of lease to be given to tenant in case of, I7I.

when lease antedates incumbrance, lease preserved in case of, 172 .

when rent is paid in advance, in case of, 173.

rent before and after date of sheriff's deed, 174 .

right of a purchaser at an orphans' court sale to rents or possession, I75.

\section{TRUSTEE}

power to lease, $5 \mathbf{I}$.

\section{UNDERLETTING}

directions in case of, 465 .

giving sub-tenants benefit of exemption law, 478 .

implied indemnity to under-tenant, 185 .

WAGES

preference of, over rent, 240. 




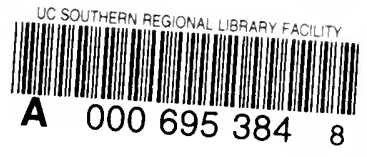




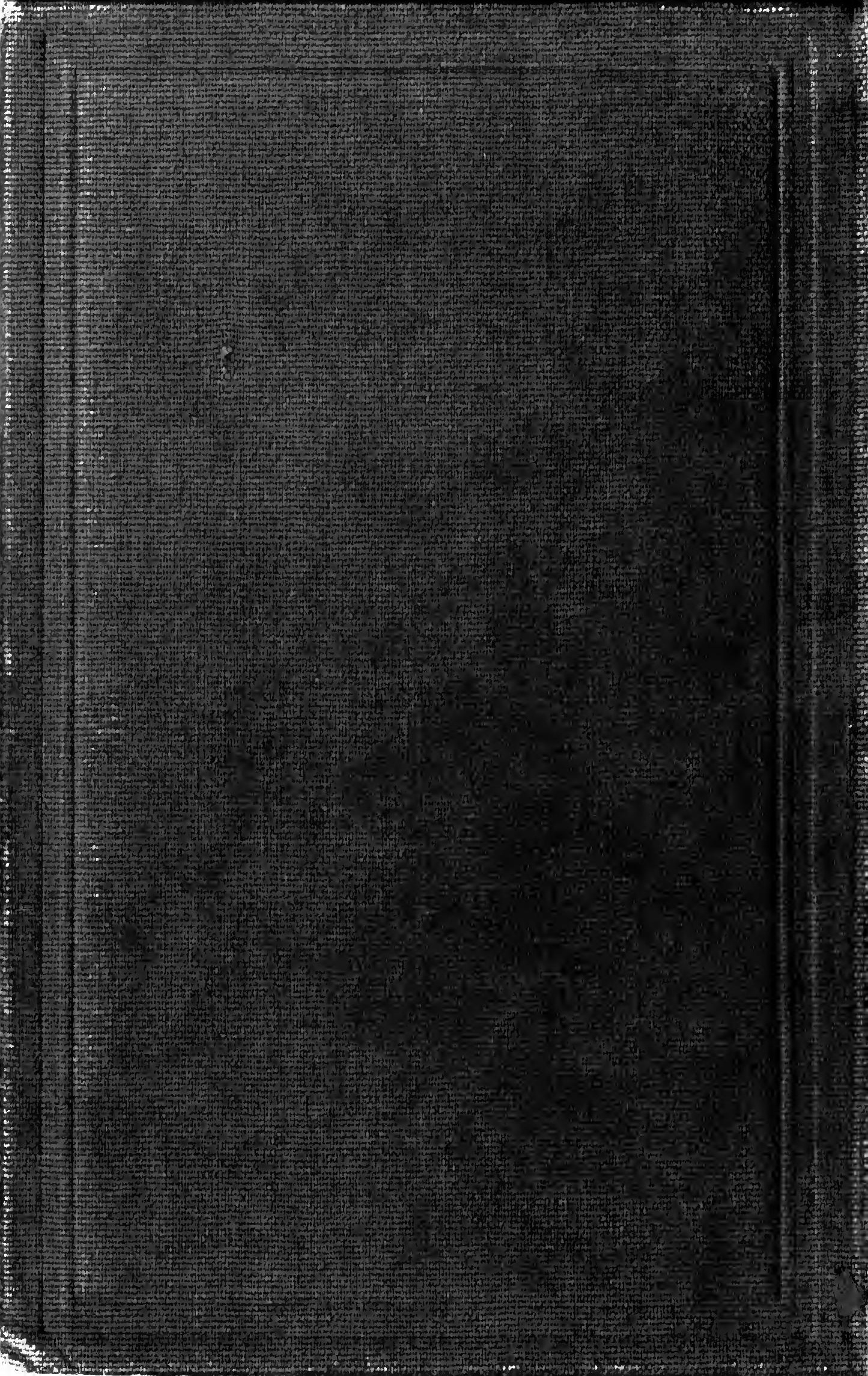

